\title{
Site U1335
}

\author{
Expedition 320/321 Scientists ${ }^{2}$
}

\section{Chapter contents}

Background and objectives. . . . . . . . 1

Science summary.................. 3

Operations................. 7

Lithostratigraphy..............8

Biostratigraphy ................ 11

Paleomagnetism ............... 16

Geochemistry ................ 18

Physical properties . . . . . . . . . . . . 19

Stratigraphic correlation and composite

section................... 21

Downhole measurements . . . . . . . . . 21

References................. 22

Figures.................... 24

Tables....................... 70

${ }^{1}$ Expedition 320/321 Scientists, 2010. Site U1335. In Pälike, H., Lyle, M., Nishi, H., Raffi, I., Gamage, K., Klaus, A., and the Expedition 320/321 Scientists, Proc. IODP, 320/321: Tokyo (Integrated Ocean Drilling Program Management International, Inc.).

doi:10.2204/iodp.proc.320321.107.2010

'Expedition 320/321 Scientists' addresses.

\section{Background and objectives}

Integrated Ocean Drilling Program (IODP) Site U1335 $\left(5^{\circ} 18.735^{\prime} \mathrm{N}, 126^{\circ} 17.002^{\prime} \mathrm{W} ; 4327.5\right.$ meters below sea level [mbsl]) (Fig. F1; Table T1) is located in the central area drilled during the Pacific Equatorial Age Transect (PEAT) program (IODP Expedition $320 / 321)$. Site U1335 ( 26 Ma crust) is situated halfway between IODP Site U1336 340 km to the northwest and IODP Site U1337 $\sim 390 \mathrm{~km}$ to the southeast, $\sim 250 \mathrm{~km}$ south of the Clipperton Fracture Zone. Site U1335 is located on a broad plateau within north-northeast-trending abyssal hill topography. Thick sediment deposits cover the abyssal hills, with a thinning sediment cover on the hills. Site U1335 is draped with $\sim 420$ m of sediment cover (Fig. F2), estimated to be $\sim 360 \mathrm{~m}$ prior to drilling. Water depth in the vicinity of Site U1335 is between 4300 and $4400 \mathrm{~m}$, apart from the topography around seamounts that are $15-20 \mathrm{~km}$ away from the drill site (Fig. F1B).

Based on stage-pole reconstructions of Pacific plate motion and observations of basement age from previous drilling sites, along with magnetic anomaly maps (Cande et al., 1989), we estimated prior to drilling that Site U1335 is located on 26 Ma crust. The best control on age is information from Deep Sea Drilling Project (DSDP) Site 79 , located $\sim 600 \mathrm{~km}$ and $4.5^{\circ}$ east and $3^{\circ}$ south of Site U1335, apparently on the same fracture zone segment, with the Clipperton Fracture Zone to the north. The base of Site 79 reaches the Miocene/Oligocene boundary, or $\sim 23 \mathrm{Ma}$ on the most recent astronomically calibrated timescales.

Site U1335 was proposed for drilling to focus on the paleoceanographic events in the late Oligocene and into the early and middle Miocene, including the climatically significant OligoceneMiocene transition and recovery from the Mi-1 glaciation event. In conjunction with Sites U1336 and U1337, it was also designed to provide a latitudinal transect for early Miocene age slices.

At the end of the Oligocene, a significant multimillion year long rise in the oxygen isotope record (Lear et al., 2004) is closely followed by a relatively short, sharp increase in oxygen isotope values that has been interpreted as a major glacial episode (Mi-1) (Zachos et al. 1997, 2001a, 2001b; Pälike et al., 2006a, 2006b) and correlated to a pronounced drop in sea level (Miller et al., 1991). This event is very close to the Oligocene/Miocene boundary and has now been astronomically age calibrated in several ocean basins (Shackleton et al., 2000; Billups et al., 2004; Pälike et al., 
2006b). Although there are clear periodic isotopic signals indicating major changes in ice volume, ocean temperatures, and/or ocean structure, this biostratigraphic boundary has always been somewhat of an enigma. Unlike the major changes in isotopic stratigraphy, biostratigraphies of the planktonic microfossils show very little change at all across this boundary. In fact, it is one of the most difficult epoch boundaries to pick using only microfossil biostratigraphies.

At Ocean Drilling Program (ODP) Leg 199 Sites 1218 and 1219 this interval was well recovered; however, carbonate preservation still presented a problem for foraminifer stratigraphy. Both sites were deep and well within the lysocline, making the application of temperature proxies such as $\mathrm{Mg} / \mathrm{Ca}$ ratios in foraminifer tests more difficult (Lear et al., 2008). At the time Miocene-Oligocene sediments were deposited, Site 1218 already resided on 18 m.y. old crust and was $\sim 4100$ m deep. Site 1219 was on $\sim 34$ m.y. old crust and was $\sim 4.5 \mathrm{~km}$ deep (Lyle, Wilson, Janecek, et al., 2002). There was a relative increase in large diatoms near this boundary in the siliceous coarse fraction, suggesting increased productivity; however, detailed high-resolution flux rates across this interval have yet to be determined. A well-recovered section on the latest Oligocene Equator, near the late Oligocene ridge crest as targeted by Site U1335, should provide both the resolution and the preservation required to better describe the changes in the equatorial ocean taking place at this time.

We positioned Site U1335 and the other PEAT sites slightly south of the estimated paleoequatorial position at their target ages in order to maximize the time that drill sites remain within the equatorial zone (i.e., $\pm 2^{\circ}$ of the Equator), to allow for some southward bias of the equatorial sediment mound relative to the hotspot frame of reference (Knappenberger, 2000), and to place the interval of maximum interest above the basal hydrothermal sediments. We located the site using the digital age grid of seafloor age from Müller et al. (1997), heavily modified and improved with additional magnetic anomaly picks from Petronotis (1991), Petronotis et al. (1994), and DSDP/ODP basement ages. For this grid, each point is then backrotated in time to zero age, using the fixed-hotspot stage-poles from Koppers et al. (2001) and Engebretson et al. (1985) and the paleopole data from Sager and Pringle (1988). From the backtracked latitudes for each grid point we then obtained the paleoequator at the crustal age by contouring.

One of the common objectives of the PEAT program for all sites is to provide a limited depth transect for several Cenozoic key horizons, such as the EoceneOligocene transition (Coxall et al., 2005) and Oligocene-Miocene transition (Shackleton et al., 2000; Pälike et al., 2006b; Zachos et al., 2001b). For this objective, Sites U1335-U1337 will form a combined depth transect for Oligocene-Miocene time. Site U1335 had an estimated crustal paleodepth of $\sim 3.3 \mathrm{~km}$ during the Oligocene-Miocene transition.

All Expedition 320/321 drill sites have in common the objective to improve and extend the extensive intercalibrated bio-, magneto-, chemo-, and astronomical stratigraphies for the Cenozoic (e.g., Shackleton et al., 2000; Pälike et al., 2006a).

The seismic reflection data (Fig. F2) (Pälike et al., 2008; Lyle et al., 2006) allowed us to optimize the Site U1335 position on seismic Line PEAT-6C-sl-8, which trends north-south. Site U1335 was moved south of the intersection of this line with the eastwest Cross-line PEAT-6C-sl-1 to better image basement and obtain a more expanded lower sediment section. We estimated sediment thickness using interval velocities published for DSDP Site 574 by Mayer et al. (1985), which drilling determined later to underestimate the basal interval velocities and therefore total sediment thickness. The subbottom profiler sections image $\sim 20 \mathrm{~m}$ of transparent surface sediment and $\sim 100 \mathrm{~m}$ of layered sediments in the upper sediment column (Pälike et al., 2008). Site U1335 is located along the flank of a wide valley that trends north-northeast, on elevated seafloor above a moat around the seamounts (Fig. F1B). Sediment cover is thick on the plateau but is highly variable along the edges. There is variable sedimentation along the eastern edge and the thick sediment cover on the plateau ranging from 300 to $600 \mathrm{~ms}$ two-way traveltime (TWT) (Lyle et al., 2006; Pälike et al., 2008). Nevertheless, the seafloor is relatively flat because the sediment has filled in the basement topography at $200 \mathrm{~ms}$ TWT. Based on correlation to the central equatorial Pacific seismic stratigraphy of Mayer et al. (1985), middle Miocene sediment has been exposed.

A site survey piston Core RR0603-6JC was taken east of Site U1335 (Fig. F1B). The cores recovered mottled brown to light brown cyclic carbonates and siliceous biogenic sediments with carbonate contents between 20 and 85 wt $\%$. Survey piston core sediments range from foraminifer-nannofossil oozes with radiolarians and diatoms to radiolarian-diatom oozes with foraminifers and nannofossils. The age at the base of this core is $\sim 2.4 \mathrm{Ma}$ based on calcareous nannofossil stratigraphy and a tie from the physical property data to the global isotope stratigraphy. 


\section{Science summary}

Two holes were cored at Site U1335 $\left(5^{\circ} 18.735^{\prime} \mathrm{N}\right.$, $126^{\circ} 17.002^{\prime} \mathrm{W} ; 4327.5 \mathrm{mbsl}$ ) (Fig. F1; Table T1), targeting paleoceanographic events in the late Oligocene and into the early and middle Miocene, including and focusing on the climatically significant Oligocene-Miocene transition and the recovery from the Mi-1 glaciation event (Zachos et al., 2001b; Pälike et al., 2006a) and the expansion of the East Antarctic cryosphere (Holbourn et al., 2005). Site U1335 also provides data toward a depth transect across the latest Oligocene and Miocene (see "Latest Oligocene-earliest Miocene [Site U1335; 26 Ma crust]" in the "Expedition 320/321 summary" chapter) that will allow exploitation and verification of a previous astronomical age calibration from Site 1218 (Pälike et al., 2006b).

Site U1335 ( 26 Ma crust) is situated halfway between Site U1336 340 km toward the northwest and Site U1337 $\sim 390 \mathrm{~km}$ toward the southeast, $\sim 250 \mathrm{~km}$ south of the Clipperton Fracture Zone (Lyle et al., 2006). At Site U1335, seafloor basalt is overlain by $\sim 414 \mathrm{~m}$ of pelagic sediment. The oldest sediment is of late Oligocene age (26 Ma).

The sedimentary sequence at Site U1335 is divided into two major lithologic units (see "Lithostratigraphy"). The topmost $\sim 64 \mathrm{~m}$ thick lithologic Unit I comprises an alternating sequence of earliest late Miocene to Pleistocene calcareous nannofossil, diatom, radiolarian, and foraminifer oozes. The topmost sediment of Unit I is younger than the Pleistocene/ Pliocene boundary (see "Biostratigraphy") as recognized by the top of planktonic foraminifer Globigerinoides fistulosus (between Samples 320-U1335A-1H-CC and $2 \mathrm{H}-2,104-106 \mathrm{~cm}$ ) and then follows a continuous biostratigraphic succession to the early late Miocene. Below, lithologic Unit II comprises a $\sim 350 \mathrm{~m}$ thick succession of late Miocene to late Oligocene (calcareous nannofossil Zone NP25) nannofossil ooze and chalk overlying basalt (lithologic Unit III) (Figs. F3, F4). One of the prominent features of Unit II is the presence of at least 49 described beds (2$176 \mathrm{~cm}$ thick) of nannofossil foraminifer ooze that have sharp basal boundaries, many of which are irregular and some of which are inclined. These beds are interpreted as gravity flow deposits from the nearby seamounts and represent $\sim 2 \%$ of the total sediment recovered.

Holes U1335A and U1335B provided high-quality advanced piston corer (APC)-cored sediments from the mudline to $\sim 341$ and $378 \mathrm{~m}$ core depth below seafloor (CSF), respectively (Cores 320-U1335A-36H and $320-\mathrm{U} 1335 \mathrm{~B}-41 \mathrm{H})$. At the time it was recovered, the APC-cored interval from Hole U1335B repre- sented the second deepest APC-cored depth in ODP and IODP history. Below this depth we encountered stiffer and harder sediment, after which we switched to the extended core barrel (XCB) cutting shoe. $\mathrm{XCB}$ coring advanced to $\sim 420 \mathrm{~m}$ drilling depth below seafloor (DSF) through lower Miocene and upper Oligocene sediments with high recovery. In the basal section, Core 320-U1335B-46X recovered pieces of basalt up to $10 \mathrm{~cm}$ in length with a glassy rim and overlain by nannofossil chalks of Unit II. For detailed coring activities, see "Operations."

The sediment column at Site U1335 represents the youngest end-member drilled during Expedition 320 and provides one of the most stratigraphically complete and expanded lower Miocene sections from the equatorial Pacific to date $(\sim 320 \mathrm{~m}$ cored depth from the lowermost to uppermost Miocene).

At Site U1335, carbonate content fluctuates between 12 and 87 wt\% within Unit I (see "Geochemistry") (Fig. F5), presumably reflecting the close proximity of the seafloor to the lysocline. With the exception of the depth interval from 140 to $220 \mathrm{~m} \mathrm{CSF}$, the remainder of Unit II exhibits uniformly high calcium carbonate content between 80 and $90 \mathrm{wt} \%$. From $\sim 150$ to $210 \mathrm{~m}$ CSF (approximately equivalent to Cores $320-\mathrm{U} 1335 \mathrm{~A}-16 \mathrm{H}$ through $22 \mathrm{H}$ ), carbonate content cycles between $\sim 50$ and $90 \mathrm{wt} \%$ and corresponds to a change in dominant sediment color from light greenish gray to tan, displaying higher magnetic susceptibility values up to $25 \times 10^{-5} \mathrm{SI}$.

A series of upper Oligocene through upper middle Miocene cores (320-U1335A-8H through 40X) were recovered with distinct colors ranging from light grayish green to light blue (see "Lithostratigraphy"), similar but much thicker in total stratigraphic thickness ( 70-170 and $\sim 200-350 \mathrm{~m})$ than those observed at Site U1334 (see the "Site U1334" chapter). The colored carbonate oozes have extremely low magnetic susceptibilities that complicated a confident stratigraphic correlation. These colored oozes have lost almost their entire magnetic susceptibility signal from $\sim 70$ to $\sim 105 \mathrm{~m} \mathrm{CSF}$ and below $\sim 210 \mathrm{~m}$ CSF (Figs. F4, F6, F7). Similar colored cores have previously been described for DSDP Sites 78 and 79 (Hays et al., 1972).

All major microfossil groups occur in sediments from Site U1335, representing a complete biostratigraphic succession at the shipboard sample resolution level of Pleistocene to uppermost Oligocene sediments, including a thick sequence of lower Miocene nannofossil ooze and chalk (see "Biostratigraphy"). Radiolarians are present through most of the section apart from the basal $3 \mathrm{~m}$ of nannofossil chalk. They provide a coherent high-resolution biochronology through a complete sequence of radiolarian zones 
from RN14 (Pleistocene) to RP21 (upper Oligocene). Calcareous nannofossils are present and moderately to well preserved through most of the succession, representing the complete sequence from Zone NP25 (upper Oligocene) above basaltic basement through Zone NN20 (Pleistocene). Planktonic foraminifers are present throughout the succession and are moderately to well preserved. Recognized planktonic foraminifer zones range from Zone PT1a (Pleistocene) to Zone O6 (upper Oligocene). Nannofossil, radiolarian, and planktonic foraminifer datums are in good agreement. Benthic foraminifers are present through most of the section and indicate lower bathyal to abyssal paleodepths. The Oligocene-Miocene transition at Site U1335 was encountered at $\sim 350 \mathrm{~m}$ and was fully recovered in Cores 320-U1335A-37X and $320-\mathrm{U} 1335 \mathrm{~B}-38 \mathrm{H}$ as approximated by the planktonic foraminifer datum base of Paragloborotalia kugleri between Samples 320-U1335A-37X-4, 136-138 cm, and $37 \mathrm{X}$-CC (midpoint $=348.6 \mathrm{~m} \mathrm{CSF}$ ), in good agreement with the calcareous nannofossil event top of Sphenolithus delphix at 349.7 m CSF between Samples 320-U1335A-37X-6, $50 \mathrm{~cm}$, and 37X-CC. The oldest sediment overlying seafloor basalt has been assigned to calcareous nannofossil Zone NP25 (24.4-26.8 Ma).

Sedimentation rates, as derived from the magnetoand biostratigraphic age determinations (see "Stratigraphic correlation and composite section"), vary throughout the section and are $\sim 6 \mathrm{~m} / \mathrm{m}$.y. in the late to middle Miocene to recent sediment cover, $\sim 17 \mathrm{~m} / \mathrm{m}$.y. in the middle early Miocene and as high as $\sim 25 \mathrm{~m} / \mathrm{m}$.y. throughout the late Oligocene and early Miocene. There is no obvious hiatus at the shipboard biostratigraphic resolution, although some condensed horizons exist (e.g., near the early/middle Miocene boundary and in the early late Miocene; see "Biostratigraphy"). The presence of all major fossil groups as well as a detailed and partly well resolved magnetostratigraphy will allow us to achieve one of the main PEAT objectives of arriving at an integrated Cenozoic stratigraphy and age calibration for the Miocene and late Oligocene.

A full physical property program was run on cores from Site U1335. This program comprises WholeRound Multisensor Logger (WRMSL) measurements of magnetic susceptibility, bulk density, and $P$-wave velocity; natural gamma radiation (NGR); and measurements of color reflectance, followed by discrete measurements of moisture and density (MAD) properties, sound velocities, and thermal conductivity in Hole U1335A. All track data vary throughout the section, allowing a detailed correlation among holes, with the exception of a low magnetic susceptibility signal within an interval extending slightly above and below the light greenish gray tinted cores of
Unit II (see "Lithostratigraphy" for exact color definitions), between $\sim 70$ and 110 and $\sim 210$ and $\sim 380 \mathrm{~m}$ CSF. Magnetic susceptibility varies between $5 \times 10^{-5}$ and $20 \times 10^{-5} \mathrm{SI}$ in the upper parts of Unit I and then increases to $\sim 25 \times 10^{-5}$ SI toward the lower part of Unit I, coinciding with the presence of clayey radiolarian ooze within the major lithology of nannofossil ooze. Magnetic susceptibility values decrease at the top of Unit II ( $\sim 64 \mathrm{~m} \mathrm{CSF})$ and then fall to values around $-1 \times 10^{-5}$ SI near $70 \mathrm{~m}$ CSF. Between $\sim 110$ and $150 \mathrm{~m} \mathrm{CSF}$, magnetic susceptibility values increase slightly and become highly variable ( 0 to $10 \times 10^{-5}$ SI). Magnetic susceptibility values are higher in the interval from 160 to $200 \mathrm{~m}$ CSF, coinciding with an observed decrease in Fe reduction (see "Lithostratigraphy"). Below $200 \mathrm{~m} \mathrm{CSF}$, the magnetic susceptibility signature is dominantly diamagnetic, with values close to zero. Magnetic susceptibility values slightly increase again in the basal $20 \mathrm{~m}$ of Unit II (below $\sim 400 \mathrm{~m} \mathrm{CSF})$. NGR is elevated at the surface sediment ( $\sim 3$ counts per second [cps]) but low throughout the rest of the sedimentary column. $P$-wave velocities from the WRMSL agree with discrete velocity measurements and reflect key lithologic transitions, particularly the ooze to chalk transition near $\sim 220 \mathrm{~m}$ CSF. $P$-wave velocities are between 1460 and $1490 \mathrm{~m} / \mathrm{s}$ in Unit I and the upper part of Unit II and then increase to $>1500 \mathrm{~m} / \mathrm{s}$. Slightly below the ooze-chalk transition near $345 \mathrm{~m}$ CSF, velocities increase significantly, reaching $1600-1750 \mathrm{~m} / \mathrm{s}$ at the bottom of Unit II. This partly explains the thicker sediment section than was expected from seismic data prior to coring ( $60 \mathrm{~m}$ thicker). Bulk density and grain density increase with depth, with an increase in wet bulk density from 1.2 to $1.6 \mathrm{~g} / \mathrm{cm}^{3}$ in Unit I to $1.7 \mathrm{~g} / \mathrm{cm}^{3}$ at the top of Unit II and $\sim 1.8 \mathrm{~g} / \mathrm{cm}^{3}$ in the basal part of the section. Sediment porosity ranges from $70 \%$ to $90 \%$ in Unit I to $50 \%-60 \%$ at $~ 300$ m CSF in Unit II. Ephemeral whole-round samples were collected at $\sim 96, \sim 196$, and $\sim 305 \mathrm{~m}$ CSF for shore-based studies of sediment permeability.

The coring effort in Holes U1335A and U1335B was successful at covering stratigraphic gaps between cores at this site from the surface throughout most of the APC-cored section (see "Stratigraphic correlation and composite section"), with the exception of a gap $(\sim 1 \mathrm{~m})$ at the bottom of Core $320-\mathrm{U} 1335 \mathrm{~A}-16 \mathrm{H}$ due to flow-in ( 146.40-151.46 m CSF). Features in magnetic susceptibility and gamma ray attenuation (GRA) density are well aligned down to a depth of $337 \mathrm{~m}$ CSF (Hole 1335A) and $344 \mathrm{~m}$ CSF (Hole U1335B), corresponding to $\sim 398 \mathrm{~m}$ core composite depth below seafloor (CCSF-A). Between $\sim 230$ and $\sim 398$ m CCSF-A, GRA density data allowed confident alignment of cores despite very low magnetic suscep- 
tibility values. The section below $\sim 398$ m CCSF-A was mostly XCB cores, lacked clearly identifiable features, and therefore had to be appended to the splice. A single spliced record was assembled for the aligned cores down to Section 320-U1335B-37H-6 (343.76 m CSF; 398.15 m CCSF-A). Stratigraphic correlation between individual holes indicates a growth factor (ratio between the CCSF-A and CSF depth scales) of $\sim 16 \%$. Stratigraphic correlation resulted in a complete splice through the Eocene-Oligocene transition almost to basement ( $38 \mathrm{Ma})$.

A full range of paleomagnetic analyses was conducted on 78 archive halves and 257 discrete samples from Site U1335 for the APC-cored section (upper $\sim 378 \mathrm{~m}$ ). The most prominent feature of the records is the magnetic intensity and susceptibility low that occurs between $\sim 70$ and $110 \mathrm{~m}$ CSF and below $\sim 210 \mathrm{~m}$ CSF. We could not obtain any reliable paleomagnetic directions from this interval because the magnetic intensity after $20 \mathrm{mT}$ alternating field (AF) demagnetization is on the order of $10^{-5} \mathrm{~A} / \mathrm{m}$, which is comparable to the noise level of the superconducting rock magnetometer (see "Paleomagnetism"). The drilling overprint was generally weak when nonmagnetic core barrels were used (Cores 320-U1335A-1H through $16 \mathrm{H}$ and $320-\mathrm{U} 1335 \mathrm{~B}-1 \mathrm{H}$ through $19 \mathrm{H}$ ). In contrast, cores collected with the steel core barrels are highly overprinted. Except for the low magnetic intensity interval, the cleaned paleomagnetic data provide a series of distinct $\sim 180^{\circ}$ alternations in declination. When combined with biostratigraphic age constraints (see "Biostratigraphy"), the data allow a continuous magnetostratigraphy from Chrons C1n (0-0.781 Ma) to C5n.2n (9.987-11.040 Ma) from 0 to $65.95 \mathrm{~m} \mathrm{CSF}$ in Hole U1335A and from Chrons C1n to C5r.1n (11.118-11.154 Ma) from 0 to 66.225 $\mathrm{m}$ CSF in Hole U1335B. Below the bottom of the first magnetic low zone ( 70-110 m CSF), magnetostratigraphy is again interpretable downhole: from Chrons $\mathrm{C} 5 \mathrm{Br}$ (15.160-15.974 Ma) to C6n (18.748-19.722 Ma) from 155.35 to $208.40 \mathrm{~m}$ CSF in Hole U1335A and from Chrons C5AAn (13.015$13.183 \mathrm{Ma})$ to C5Er (18.524-18.748 Ma) from 107.95 to $202.60 \mathrm{~m}$ CSF in Hole U1335B. The highlights of the magnetostratigraphy at Site U1335 are the identifications of (1) a previously observed cryptochron (C5Dr-1n) in two holes and (2) 40 potential geomagnetic excursions (10 of which are recorded in both holes).

A standard shipboard suite of geochemical analyses of pore water and organic and inorganic sediment properties was undertaken on samples from Site U1335. Site U1335 is marked by alkalinities between 2.5 and $4.3 \mathrm{mM}$ throughout, sulfate concentrations between 23 and $28 \mathrm{mM}$, and dissolved phosphate concentrations of $\sim 2 \mu \mathrm{M}$ in the shallowest sample, decreasing to $\sim 0.5 \mu \mathrm{M}$ in the uppermost $\sim 50 \mathrm{~m}$. The most striking features in the interstitial water geochemistry are three dissolved manganese peaks with concentrations of up to 44,13 , and $5 \mu \mathrm{M}$ at $\sim 0-40$, 50-80, and 150-210 m CSF, respectively. Dissolved iron also shows three peaks, with concentrations up to $6 \mu \mathrm{M}$ at $\sim 6 \mathrm{~m} \mathrm{CSF}$, between 90 and $170 \mathrm{~m} \mathrm{CSF}$, and between 190 and $370 \mathrm{~m}$ CSF. Minima in dissolved Fe correspond to elevated Mn concentrations. The alternating pattern of dissolved $\mathrm{Mn}$ and Fe correspond well to apparent color changes in the sediment column (see "Lithostratigraphy"). Lithium concentrations decrease from $\sim 26 \mu \mathrm{M}$ at the sediment surface to $5 \mu \mathrm{M}$ at $\sim 300 \mathrm{~m} \mathrm{CSF}$, below which Li concentrations increase strongly to $\sim 32 \mu \mathrm{M}$. The Sr concentration profile mirrors that of $\mathrm{Li}$, with concentrations ranging between 82 and $250 \mu \mathrm{M}$. Sr values increase from the top to $200 \mathrm{~m} \mathrm{CSF}$, followed by a decrease toward basement. Calcium carbonate, inorganic carbon (IC), and total carbon (TC) contents were determined on sediment samples from Hole U1335A (Fig. F5). $\mathrm{CaCO}_{3}$ contents ranged between 13 and $96 \mathrm{wt} \%$. In the uppermost $\sim 67 \mathrm{~m}$, carbonate contents range from 12 to $87 \mathrm{wt} \%$, and concentrations are then consistently high ( 72-96 wt $\%)$ between 67 and $157 \mathrm{~m}$ CSF and below $222 \mathrm{~m}$ CSF. Carbonate contents vary more widely (between 37 and $89 \mathrm{wt} \%$ ) from 157 to $222 \mathrm{~m}$ CSF. Total organic carbon (TOC) concentrations were determined by acidification and are generally low.

Wireline logging was not conducted at Site U1335. Five downhole temperature measurements were conducted in Hole U1335B with the advanced piston corer temperature tool (APCT-3) and reveal a thermal gradient of $7.5^{\circ} \mathrm{C} / \mathrm{km}$. Temperature data combined with whole-round core temperature conductivity measurements indicate the heat flow is $7 \mathrm{~mW} / \mathrm{m}^{2}$ at this site. This is much lower than values obtained for any of the other Expedition 320 sites and would suggest recirculation of seawater through basement, consistent with some of the interstitial pore water results (see "Geochemistry").

\section{Highlights}

Highly expanded Miocene sedimentary section

One of the highlights from Site U1335 is the recovery of a thick Miocene carbonate-dominated section from the central equatorial Pacific, one of the highpriority objectives of the PEAT program. The early Miocene (7.1 m.y. duration) is captured in $\sim 190 \mathrm{~m}$ of sediment, corresponding to a sedimentation rate of $27 \mathrm{~m} / \mathrm{m}$.y. The middle Miocene (4.4 m.y. duration) is recovered in $\sim 95 \mathrm{~m}$ sediment, with a sedimentation rate of $\sim 21 \mathrm{~m} / \mathrm{m}$.y. The sedimentation rate from the 
late Oligocene into the Miocene is just under $20 \mathrm{~m} / \mathrm{m}$.y. These high sedimentation rates will facilitate the study of paleoceanographic processes at unprecedented resolution for the equatorial Pacific.

\section{Oligocene-Miocene transition and depth transects}

Site U1335 was planned as the youngest and shallowest component of the PEAT Oligocene-Miocene depth transect component, which will allow the study of critical intervals (such as the Mi- 1 glacial inception; see Zachos et al., 2001b; Pälike et al., 2006a) and variations of the equatorial calcium carbonate compensation depth (CCD) throughout this transition and during the latest Oligocene and early Miocene. Site U1335 is estimated to have been $\sim 3.3 \mathrm{~km}$ deep during the Oligocene-Miocene transition, $\sim 1.5 \mathrm{~km}$ shallower than today. The dominant lithologies are nannofossil ooze and chalk, with better preservation of calcareous microfossils than any other site drilled during Expedition 320, which will allow us to achieve the prime objective for this site. Physical property data from Site U1335 provide an important contribution toward the Cenozoic megasplice, connecting with younger sediments from ODP Leg 138 (e.g., Site 850) and older sediments from Leg 199 (Site 1218), allowing the generation of astronomically calibrated datums and isotope stratigraphies from the Miocene into the Eocene.

\section{Geochemical front}

At Site U1335 we recovered an interval of light greenish gray carbonates that show a distinct peak in dissolved Fe concentrations, characteristic of a geochemical alteration front. At Site U1335, this zone is similar to but much thicker in total stratigraphic thickness ( 70-170 and $\sim 200-350 \mathrm{~m} \mathrm{CSF})$ than that observed at Site U1334 ( 50 m; see the "Site U1334" chapter). Although the paleomagnetic signal was lost in most parts of this section, sediments recovered will provide the opportunity to study organic matter degradation while these sites migrated from south to north through the equatorial belts of high productivity. Paleolatitudinal reconstructions show that these characteristic geochemical alteration fronts can be mapped to similar equatorial positions between Sites U1334 and U1335, roughly between the Equator and $\sim 2^{\circ} \mathrm{N}$. One feature of interest at Site U1335 is the observation that the multicolored interval of sediments is interrupted between $\sim 170$ and $200 \mathrm{~m}$ CSF (Cores 320-U1335A-18H through 20H), again showing higher magnetic susceptibility values. It remains to be established whether this interrup- tion in the geochemical alteration front is related to the shape and position of the equatorial highproductivity zone or instead is the result of reduced sedimentation rates during this time (late early Miocene). Interstitial pore water profiles provide additional important information about the redox chemical processes operating in this zone (see "Geochemistry"), which have also been observed at Sites 78, 79, and 574 (e.g., Hays et al., 1972).

\section{Gravity flow deposits}

One of the prominent features of Unit II is the presence of at least 49 described beds $(2-176 \mathrm{~cm}$ thick) of nannofossil foraminifer ooze that have sharp basal boundaries, many of which are irregular and some of which are inclined. These beds are interpreted as gravity flow deposits from the nearby seamounts and represent $\sim 2 \%$ of the total sediment recovered. Their grain size fines upward from medium sand to silt, and they are often darker colored than immediately overlying deposits and instantly recognizable by their coarser texture. Angular basalt fragments $(<1 \mathrm{~mm})$, fish teeth, and pyritized foraminifers and radiolarians were also found within the basal parts of these beds, of which at least three show parallel or cross-laminations in their upper or middle part. These beds, interpreted as gravity flow deposits, are present with an approximate frequency of one or two beds per core. The abundance and thickness of these beds is highest within Cores 320-U1335-21H through 37X (189.4-350.1 m CSF). No gravity flow deposits were observed in Cores 320-U1335A-3H through $8 \mathrm{H}$. The provenance of these deposits, as indicated by the observed basalt fragments, is inferred to be the nearby seamounts (Fig. F1B) situated $\sim 15-$ $20 \mathrm{~km}$ northeast and southeast of Site U1335, with present summit water depths that are 400-600 m shallower than Site U1335. Initial indications are that these gravity flow deposits, unlike those observed at Site U1331, might not be very erosive and therefore essentially add to the sediment column rather than removing large sections of geological time. The high sedimentation rates at Site U1335 will allow paleoceanographic studies to avoid the generally thin layers of gravity flows.

\section{Age transect of seafloor basalt}

At Site U1335 we recovered what appear to be fresh fragments of seafloor basalt with an age of $\sim 26 \mathrm{Ma}$, as inferred by the oldest biostratigraphic datums from the sediment above. This material will, when combined with other PEAT basalt samples, provide important sample material for the study of seawater alteration of basalt. 


\section{Operations}

Times for Site U1335 are given in local ship time, which was universal time coordinated (UTC) $-9 \mathrm{~h}$.

\section{Transit to Site U1335}

The $375 \mathrm{nmi}$ voyage from Site U1334 to Site U1335 took $42.3 \mathrm{~h}$ at an average speed of $8.9 \mathrm{kt}$. Shortly after departing Site U1334, propulsion Motor 16A on the port propeller shaft had to be taken offline because of defective field coils. This was the second propulsion motor to exhibit the same problem during Expedition 320. Propulsion Motor 15A on the starboard shaft had to be removed from the grid shortly after leaving Honolulu. It is expected that these units will be repaired during the port call in Honolulu. The rest of the voyage was made with reduced revolutions on both shafts $(120 \mathrm{rpm}$ instead of $140 \mathrm{rpm})$. Although capable of higher shaft revolutions, the lower shaft power was necessary to keep the ambient temperature in the propulsion room from moving into a critically high range.

\section{Site U1335}

\section{Hole U1335A}

The ship slowed and was in dynamic positioning (DP) mode over Hole U1335A at $1630 \mathrm{~h}$ on 15 April 2009. We assembled the drill string, lowered it to the seafloor, and started coring Hole U1335A at $0355 \mathrm{~h}$ on 16 April. The estimated water depth based on the recovery of the first core was $4339.0 \mathrm{~m}$ DRF (4327.5 mbsl) (Table T1).

Cores $1 \mathrm{H}$ through $36 \mathrm{H}$ were taken from 0 to $341.4 \mathrm{~m}$ DSF, and we recovered $354.7 \mathrm{~m}$ (104\%) (Table T1). APC piston coring to this depth is an operational highlight for this site. Nonmagnetic core barrels were used for Cores $1 \mathrm{H}$ through $16 \mathrm{H}$, and steel barrels were used for all other cores. Nine core barrels required drilling over to release them from the formation (Cores $19 \mathrm{H}$ through $22 \mathrm{H}, 26 \mathrm{H}, 27 \mathrm{H}$, and $34 \mathrm{H}$ through $36 \mathrm{H}$ ) and Cores $16 \mathrm{H}$ and $36 \mathrm{H}$ only partially stroked.

We then switched to XCB coring and took Cores $37 \mathrm{X}$ through $45 \mathrm{X}$ from 341.4 to $421.1 \mathrm{~m}$ DSF and recovered $67.9 \mathrm{~m}(85 \%)$. We retrieved Core $45 \mathrm{X}$ after taking $\sim 1 \mathrm{~h}$ to advance only $3 \mathrm{~m}$. When retrieving this core, it apparently became stuck in the drill string just above the bottom-hole assembly. We attempted to free the stuck core barrel with the wireline jars by alternating the tension on the coring line for $\sim 1 \mathrm{~h}$ when the overshot shear pin parted. Once we recovered the sinker bars and wireline jars, we pumped another core barrel down on top of it and this succeeded in dislodging the stuck core, which dropped back down to the bit. When Core $45 \mathrm{X}$ was recovered, it contained hard limestone and the XCB bit was very worn down, so we decided it was best to stop coring in this hole. The basement depth is deeper than anticipated and suggests higher seismic velocities in the sediment column from Site U1335 than those from the nearest site (574). Once Hole U1335A was completed, the bit was pulled free of the seafloor at $1725 \mathrm{~h}$ on 18 April and the vessel offset 25 m west.

\section{Hole U1335B}

We started coring Hole U1335B at 1955 h on 18 April with the bit $5 \mathrm{~m}$ deeper than at Hole U1335A. The seafloor depth based on the recovery of the first core was $4339.6 \mathrm{~m}$ DRF (4328.1 mbsl).

APC Cores $1 \mathrm{H}$ through $41 \mathrm{H}$ were taken from 0 to $378.2 \mathrm{~m}$ DSF, and we recovered $392.7 \mathrm{~m}$ (104\%). At the time, this was the second deepest APC penetration in the history of ocean drilling. Nonmagnetic core barrels were used on Cores $1 \mathrm{H}$ through $19 \mathrm{H}$, and steel barrels were used on all remaining cores. Formation temperature measurements were made with the APCT-3 at 22.3, 41.3, 60.3, 79.3, and $98.3 \mathrm{~m}$ DSF (Cores $3 \mathrm{H}, 5 \mathrm{H}, 7 \mathrm{H}, 9 \mathrm{H}$, and $11 \mathrm{H}$, respectively). Twelve core barrels had to be drilled over to release them from the formation (Cores $19 \mathrm{H}, 20 \mathrm{H}$, and $35 \mathrm{H}$ through $41 \mathrm{H})$. Cores $37 \mathrm{H}$ through $41 \mathrm{H}$ did not achieve a full stroke and were advanced by recovery.

After switching to XCB coring, we took Cores $42 \mathrm{X}$ through $46 \mathrm{X}$ from 378.2 to $417.5 \mathrm{~m}$ DSF and recovered $36.0 \mathrm{~m}$ (92\%). Coring was terminated when basement was reached.

Originally we had planned three holes at Site U1335. However, after recovering a continuous Miocene section with nearly complete recovery and overlap between the two holes, we decided to not core a third hole at Site U1335. The fact that the cores contained frequent turbidites and a very weak magnetic signal in the interval with the distinctly colored (diagenetically altered) sediment also contributed to this decision. Instead we decided to use our remaining time to core at Site U1336 to provide the second PEAT expedition more information for optimizing their operations plan.

We pulled the drill string out of the hole, and the bit cleared the seafloor at $1215 \mathrm{~h}$ on 21 April. Before the drill string was recovered, we spent $1 \mathrm{~h}$ to slip and cut $115 \mathrm{ft}$ of drill line. Once drilling line maintenance was completed, the drill string was recovered, the beacon retrieved, and the drilling equipment secured for transit. The vessel departed for Site U1336 at $2145 \mathrm{~h}$ on 21 April. 


\section{Lithostratigraphy}

Drilling at Site U1335 recovered a $\sim 420 \mathrm{~m}$ thick section of pelagic sediments overlying seafloor basalt (Fig. F4). The sedimentary sequence at Site U1335 is divided into two major lithologic units (Fig. F4; Table T2). The upper part of the sedimentary sequence (0-64 m CSF; Unit I) is characterized by an alternating sequence of multicolored nannofossil, diatom, and radiolarian oozes of early late Miocene to Pleistocene age. Unit II is a $\sim 350 \mathrm{~m}$ thick sequence of nannofossil ooze and chalk of late Oligocene to early late Miocene age. This unit is characterized by pronounced changes in color, both at the thick stratigraphic scale $(20-190 \mathrm{~m})$ (Fig. F6) and superimposed centimeter- to millimeter-scale color banding. Unit II contains many thin beds of nannofossil foraminifer ooze overlying sharp basal contacts (Fig. F4).

Lithologic units and boundaries are defined by changes in lithology, physical properties, and calcium carbonate $\left(\mathrm{CaCO}_{3}\right)$ content as measured by coulometry. Lithologic differences, based on both visual core description and smear slide observations, are primarily attributable to varying distributions of biogenic components (nannofossils, diatoms, radiolarians, and foraminifers). Lithologic descriptions are based primarily on sediments recovered in Hole U1335A, supplemented with observations from Hole U1335B.

\section{Unit I}

Intervals: 320-U1335A-1H-1, $0 \mathrm{~cm}$, through 7H-6, $44 \mathrm{~cm}$; 320-U1335B-1H-1, $0 \mathrm{~cm}$, through $8 \mathrm{H}-5$, $75 \mathrm{~cm}$

Depths: Hole U1335A = 0-64.34 m CSF; Hole $\mathrm{U} 1335 \mathrm{~B}=0-67.05 \mathrm{~m}$

Age: Pleistocene to early late Miocene

Lithology: alternation of nannofossil ooze, diatom nannofossil ooze, clayey nannofossil ooze, foraminifer nannofossil ooze, nannofossil foraminifer ooze, radiolarian diatom ooze, nannofossil diatom ooze, clayey diatom ooze, clayey radiolarian ooze, and clay

The major lithologies in Unit I are white (10YR 8/1) through dark grayish brown $(2.5 \mathrm{Y} 4 / 2)$ nannofossil ooze, very pale brown (10YR 8/2) foraminifer nannofossil ooze, very pale brown (10YR 7/3) through olive-brown $(2.5 \mathrm{Y} 4 / 3)$ diatom nannofossil ooze, light gray (10YR 7/2) to very pale brown (10YR $7 / 4$ ) radiolarian diatom ooze, very pale brown (10YR $8 / 4$ ) and olive-brown (2.5Y 4/3) nannofossil diatom ooze, dark gray (10YR 4/1) clayey nannofossil ooze, very dark grayish brown (10YR 3/2) clayey radiolarian ooze, brown (10YR 4/3) clayey diatom ooze, and brown (10YR 4/3) clay.

Sediments in Unit I show cyclic alternations in lithology of $30-80 \mathrm{~cm}$ thickness. An exception to this is a $\sim 9 \mathrm{~m}$ thick white (10YR 8/1) to very pale brown (10YR 8/2) nannofossil ooze observed between 45.5 and $54.5 \mathrm{~m}$ CSF (from interval 320U1335A-5H-6, $80 \mathrm{~cm}$, to $6 \mathrm{H}-6,9 \mathrm{~cm})$. Beneath this interval, the lowermost part of Unit I consists of clay-rich sediments of very dark grayish brown (10YR 3/2) clayey radiolarian ooze and brown (10YR $4 / 3)$ clay that alternate with grayish brown (2.5Y 5/ 2) to light brownish gray $(2.5 \mathrm{Y} 6 / 2)$ nannofossil ooze with diatoms (e.g., Cores 320-U1335A-7H and 320U1335B-7H). Clay-rich intervals are characterized by high magnetic susceptibility (up to $22 \times 10^{-5} \mathrm{SI}$ ), low $L^{*}(25-30)$, elevated $b^{*}$ and $L^{*}(10-15)$, and low GRA bulk density $\left(<1.2 \mathrm{~g} / \mathrm{cm}^{3}\right)$ values (Fig. F4). The nannofossil ooze layer shows low magnetic susceptibility $\left(<6.0 \times 10^{-5} \mathrm{SI}\right)$, high $\mathrm{L}^{*}(>80)$, low $\mathrm{b}^{*}$ $(<10)$, and high bulk density (up to $1.7 \mathrm{~g} / \mathrm{cm}^{3}$ ) values. Bioturbation is generally intense in Unit I, particularly in the alternating multicolored biogenic oozes.

The Unit I/II boundary is located at interval 320$\mathrm{U} 1335 \mathrm{~A}-7 \mathrm{H}-6,44 \mathrm{~cm}(64.34 \mathrm{~m} \mathrm{CSF})$, and is defined at the base of an alternating sequence of clayey radiolarian ooze with clay and nannofossils and nannofossil ooze with diatoms (Table T2). Below the unit boundary to interval 320-U1335A-8H-2, $50 \mathrm{~cm}$ (67.90 m CSF), physical property data show a transition to lower magnetic susceptibility, higher $L^{*}$, lower $b^{*}$, and higher GRA bulk density values (Fig. F4).

\section{Unit II}

Intervals: $320-\mathrm{U} 1335 \mathrm{~A}-7 \mathrm{H}-6,44 \mathrm{~cm}$, to at least $45 \mathrm{X}-\mathrm{CC}, 15 \mathrm{~cm}$; 320-U1335B-8H-5, $75 \mathrm{~cm}$, to 46X-CC, $8 \mathrm{~cm}$

Depths: Hole U1335A $=64.34$ to at least $420.08 \mathrm{~m}$ CSF; Hole U1335B 67.05-418.04 m CSF

Age: early late Miocene to late Oligocene

Lithology: nannofossil ooze, radiolarian nannofossil ooze, foraminifer nannofossil ooze, nannofossil foraminifer ooze, and nannofossil chalk

Major lithologies in Unit II are white (10YR 8/1) to very pale brown (10YR 8/4) and light greenish gray (10Y $8 / 1$ to $5 \mathrm{GY} 7 / 1$ ) nannofossil ooze and white (2.5Y 8/1) and pale yellow (2.5Y 7/3) nannofossil chalk. Several $10-50 \mathrm{~cm}$ thick interbedded layers of yellow (10YR 7/6) to light greenish gray (5GY 7/1) nannofossil radiolarian ooze occur in the middle part of Unit II (157-176 m CSF in Hole U1335A). In 
addition, two distinct thin beds (18-23 cm thick) of nannofossil diatom ooze are interbedded within the nannofossil ooze (Samples 320-U1335B-10H-3, 62$80 \mathrm{~cm}$, and $24 \mathrm{H}-6,40-63 \mathrm{~cm}$ ) (Figs. F8, F9). In the middle part of Unit II (157-176 m CSF in Hole $\mathrm{U} 1335 \mathrm{~A})$, some intercalations of white $(\mathrm{N} 8)$ to pale yellow (2.5Y 7/4) and light greenish gray (5GY 7/1) nannofossil ooze contain radiolarians or diatoms with abundances reaching between $10 \%$ and $25 \%$ (see "Site U1335 smear slides" in "Core descriptions"). These intervals of nannofossil radiolarian ooze, nannofossil diatom ooze, and nannofossil ooze with radiolarians or diatoms show darker colors relative to the immediately overlying and underlying nannofossil ooze intervals. Bioturbation is generally minor throughout Unit II.

One of the most prominent features of Unit II is the intercalation of at least 49 beds $(2-162 \mathrm{~cm}$ thick) of white (N 8 and 10YR 8/1), light greenish gray (10Y 8/ $1,10 \mathrm{GY} 8 / 1$, and $5 \mathrm{GY} 8 / 1$ ), and light gray (N 7) nannofossil foraminifer ooze (Table T3). These beds have sharp basal boundaries, many of which are irregular, some of which are inclined. Grain size fines upward from medium sand to silt within these beds. Basal sediments are often darker colored than the immediately overlying deposits. Basal sediments are dominated by nannofossil foraminifer ooze and are instantly recognizable in the split core by their coarse texture during preparation (surface scraping) for line scan imaging. Angular basalt fragments $(<1 \mathrm{~mm})$, fish teeth, and pyritized foraminifers and radiolarians are also found concentrated in these basal deposits (Fig. F10). At least three of these beds show parallel or cross-laminations in their middle or upper part.

In the basal part of Unit II, at least five thin $(4-13 \mathrm{~cm}$ thick) intervals of nannofossil chalk contain sand- to pebble-sized fresh basalt clasts with a glassy rim in nannofossil chalk (see "Site U1335 smear slides" in "Core descriptions"). Boundaries between basaltcontaining nannofossil ooze and adjacent nannofossil oozes are not clear because of bioturbation and XCB drilling disturbance (biscuits).

Nannofossil ooze in Unit II displays pronounced changes in color, both at the thick stratigraphic scale (20-190 m) (Fig. F6) and superimposed centimeterto millimeter-scale color banding (Fig. F11). At the top of Unit II, sediment color shifts downhole from pale yellow (2.5Y 8/2) toward white $(\mathrm{N} 8)$ and light greenish gray (10Y 8/1) around 67-72 m CSF (Hole U1335A). The white and light greenish gray color persists for $\sim 100 \mathrm{~m}$ downhole and then reverts back to pale yellow and very pale brown for $\sim 20 \mathrm{~m}$ (Fig.
F6). Below $192 \mathrm{~m}$, sediments are consistently white (N 8) and light greenish gray over a $180 \mathrm{~m}$ thick interval to $372 \mathrm{~m}$ CSF (Hole U1335A). Around $372 \mathrm{~m}$ CSF, color shifts back from white $(\mathrm{N} 8)$ to pale yellow (2.5Y 7/3) toward pale brown (10YR $7 / 3)$ to the base of the sediment column (Fig. F6). Superimposed on these gross changes in sediment color within the light greenish gray intervals millimeter- to centimeter-scale light greenish gray (5GY 8/1, 10GY 8/1, 5G 8/1, 5GY 7/1, 10GY 7/1, and 5G 7/1), light gray ( $\mathrm{N} \mathrm{7)}$, and gray ( $\mathrm{N} \mathrm{6)}$ color bands are common (Figs. F4, F11). The color bands occur both with sharply defined boundaries and with more diffusive boundaries. Sometimes the sharply defined color bands occur in discrete beds that are distinctly more consolidated than immediately over- and underlying sediments (Fig. F11). Based on smear slide observations, the lithology of the color-banded sediments (nannofossil ooze) is identical to the immediately over- and underlying sediments (see "Site U1335 smear slides" in "Core descriptions"). Submillimeter-sized opaques, presumably sulfide minerals such as pyrite, form streaks and fill burrows.

Magnetic susceptibility is extremely low in Unit II between 68 and $118 \mathrm{~m}$ CSF and between 200 and $400 \mathrm{~m}$ CSF (Fig. F4). These two intervals broadly correspond to the light greenish gray intervals. Reflectance parameters $a^{*}$ and $b^{*}$ shift in a stepwise manner to lower values or toward green $\left(a^{*}\right)$ and blue $\left(b^{*}\right)$ with the observed color shift toward light greenish gray (Fig. F6). Within the stratigraphic interval between 118 and 199 m CSF (Hole U1335A), magnetic susceptibility data show sporadic peaks that correspond to the slightly darker, siliceous fossil-rich intervals (i.e., nannofossil radiolarian ooze, nannofossil ooze with radiolarians, and nannofossil ooze with diatoms). Higher magnetic susceptibility values in the radiolarian- and diatomrich intervals indicate higher clay contents than the adjacent pure nannofossil oozes.

\section{Unit III}

Intervals: 320-U1335B-46X-CC, $8 \mathrm{~cm}$, through at least 46X-CC, $46 \mathrm{~cm}$; no basalt drilled in Hole $\mathrm{U} 1335 \mathrm{~A}$

Depth: Hole U1335B $=418.04$ to at least $418.42 \mathrm{~m}$ CSF

Lithology: basalt

Pieces of basalt up to $10 \mathrm{~cm}$ in length were recovered at the base of Hole U1335B. These basalt pieces have glassy rims and are overlain by the nannofossil chalks of Unit II. 


\section{Redox-related color changes}

The homogeneous lithology of Unit II is overprinted by vivid color changes similar to those observed at Site U1334. Light greenish gray nannofossil ooze occurs in two stratigraphic intervals, between 70 and $170 \mathrm{~m}$ and 192 and $323 \mathrm{~m}$. Magnetic susceptibility drops to near zero, and reflectance parameters $\mathrm{a}^{*}$ and $b^{*}$ shift to lower values with the observed color shifts toward light greenish gray (Fig. F6). Pore water profiles for dissolved Fe and Mn concentrations show downhole changes that are consistent with the changes in sediment color and magnetic susceptibility data (see "Geochemistry"). A significant peak in dissolved $\mathrm{Fe}$ in the pore fluids occurs in the light greenish gray intervals between 80 and $165 \mathrm{~m}$ and 203 and $316 \mathrm{~m}$ CSF (Hole U1335A), with distinct minima that correspond to the return to pale brown color and higher magnetic susceptibility between the greenish layers and at the base of the section (see "Geochemistry"). The pattern of changing sediment color, physical and magnetic properties, and pore water chemistry in the two intervals suggests loss of Fe-bearing minerals during diagenesis by microbial Fe reduction. A diagenetic origin for the color bands is suggested by (1) their occurrence in the interval of the sequence that has undergone Fe reduction, (2) their lack of lithological specificity, and (3) the consolidation sometimes associated with discrete beds that show particularly prominent banding. Similar gray and light greenish gray banding is reported from sediments recovered from Ongtong Java Plateau (ODP Leg 130), where they are enriched in iron sulfides in gray layers and in iron and magnesium silicates in green layers (Lind et al., 1993).

\section{Gravity flow deposits}

Throughout the sedimentary section drilled at Site U1335, sharp irregular contacts occur between lithologies (Table T3; Figs. F10, F12). Many of these sharp contacts are directly overlain by coarser sediment (i.e., nannofossil foraminifer ooze), generally showing a normal grading. The coarsegrained sediments directly overlying the sharp contacts are clearly of erosional origin and sometimes contain angular basalt fragments (Fig. F10), pyritized foraminifers and/or radiolarians, and fish teeth at the base. There is a concentration of grayish layers in the basal intervals of the nannofossil foraminifer ooze that may reflect increased porosity in coarse sediments and intensified iron sulfide precipitation. In some cases, coarse intervals show cross or parallel laminations in the middle of the bed. These features indicate that the erosional contacts and their overlying coarse sediments are the product of mass flow events, likely turbidity currents. The thickness of the inferred turbidites is typically between 2 and $25 \mathrm{~cm}$, with a maximum thickness of $176 \mathrm{~cm}$ in Sections 320-U1335B-36H-2 and 36H-3 (Table T3). Gravity flow deposits occur with an approximate frequency of one or two beds per core, and their total thickness occupies a minimum of $2 \%$ of the recovered sediment. The abundance and thickness of turbidites is highest within Cores 320-U1335A-21H through 37X (189.4-350.1 m CSF). In contrast, no gravity flow deposits are observed between Cores 320U1335A-3H and 8H (18.4-75.9 $\mathrm{m} \mathrm{CSF})$. The presence of basalt fragments at the base of some turbidites suggests that the provenance of the inferred turbidites observed at Site U1335 is likely one or both of the two seamounts located 15 to $20 \mathrm{~km}$ northeast and southeast (present summit water depth is $\sim 400$ $600 \mathrm{~m}$ shallower than Site U1335) (Fig. F1).

\section{Sediments across the Oligocene-Miocene transition}

The Oligocene/Miocene boundary was recovered in both holes at Site U1335 (Fig. F4). The Oligocene/ Miocene boundary (23.0 Ma) is approximated by the first appearance of the planktonic foraminifer $P$. kugleri, whereas the last occurrence of nannofossil $S$. delphix falls 100 k.y. before the Oligocene/Miocene boundary (23.1 Ma). P. kugleri is present in Sample 320-U1335A-37X-4, 136-138 cm, and the top of S. delphix falls between Samples 320-U1335A-37X-6, $50 \mathrm{~cm}$, and 37X-CC (see "Biostratigraphy"). Therefore, the Oligocene/Miocene boundary is estimated to fall between Samples 320-U1335A-37X4, 136-138 cm, and 37X-CC. Magnetostratigraphic data are not available for these intervals because of XCB coring in Hole U1335A (below Core 320U1335A-37X) and loss of signal in Hole U1335B (see "Magnetostratigraphy"). No shipboard splice is available for this interval (see "Stratigraphic correlation and composite section"). The OligoceneMiocene transition in Holes U1335A and U1335B occurs in white to light greenish gray nannofossil ooze with frequent millimeter- to centimeter-scale color bands and a sharp boundary (interval 320U1335A-37X-6, $44 \mathrm{~cm}$ ) overlain by an $18 \mathrm{~cm}$ thick bed of nannofossil foraminifer ooze that fines upward. No prominent change in lithology, GRA bulk density, reflectance, or magnetic susceptibility is seen through the Oligocene-Miocene transition.

\section{Summary}

At Site U1335, Oligocene seafloor basalt is overlain by $\sim 420 \mathrm{~m}$ of calcareous sediments that are divided into two lithologic units. The sediments are primarily composed of nannofossil oozes and nannofossil chalks. The Pleistocene through late middle 
Miocene sedimentary sequence (Unit I) contains more radiolarians, diatoms, and clay relative to the Oligocene through late middle Miocene sediments (Unit II). Unit II is characterized by homogeneous nannofossil ooze and nannofossil chalk with interbedded nannofossil radiolarian ooze that corresponds to the transition from early to middle Miocene. Unit II is marked by two intervals of major color change from very pale brown to pale yellow to light greenish gray and back to pale brown nannofossil ooze. Intervals of light greenish gray nannofossil ooze are overprinted by vivid color banding ranging from millimeter- to centimeterscale similar to that observed at Site U1334. Throughout Unit II, sharp irregular contacts are frequent and often overlain by coarser sediment (i.e., nannofossil foraminifer ooze) interpreted as mass flow events and appear to be turbidites. Fresh seafloor basalt was recovered at the base of the sedimentary section.

\section{Biostratigraphy}

At Site U1335, we recovered a $420 \mathrm{~m}$ thick succession of Pleistocene to upper Oligocene sediments, including an expanded sequence of lower Miocene nannofossil ooze and chalk. A Pliocene-Pleistocene succession of nannofossil and radiolarian ooze was recovered from the top $29 \mathrm{~m}$ of the hole. This was deposited on top of $135 \mathrm{~m}$ of upper and middle Miocene nannofossil ooze and an expanded succession of $185 \mathrm{~m}$ of lower Miocene nannofossil ooze. A $71 \mathrm{~m}$ thick interval of upper Oligocene nannofossil chalk was recovered above basement. Radiolarians are present through most of the section apart from the basal $3 \mathrm{~m}$ of nannofossil chalk. They provide a coherent, highresolution biochronology through a complete sequence of radiolarian zones from Zone RN14 (Pleistocene) to Zone RP21 (upper Oligocene). Calcareous nannofossils are present and moderately to well preserved through most of the succession. There appears to be a complete sequence of nannofossil zones from Zone NN20-21 (Pleistocene) to Zone NP25 (upper Oligocene). Planktonic foraminifers are generally well preserved throughout the section, enabling a complete sequence of planktonic foraminifer zones from Zone PT1a (Pleistocene) to Zone O6 (upper Oligocene) to be recognized. Nannofossil, radiolarian, and planktonic foraminifer datums are in good agreement. An integrated calcareous and siliceous microfossil biozonation is shown in Figure F13. A detailed age-depth plot including biostratigraphic and paleomagnetic datums is shown in Figure F14. Benthic foraminifers are present through most of the section and indicate lower bathyal to abyssal paleodepths.

\section{Calcareous nannofossils}

Calcareous nannofossil biostratigraphy is based on analysis of core catcher samples from both holes and from samples from most core sections of Hole U1335A. Depth positions and age estimates of biostratigraphic marker events are shown in Table T4. Nannofossils are generally abundant and moderately to well preserved throughout but with some intervals of poor to moderate preservation in the upper Miocene (Cores 320-U1335-4H through 8H; Zones NN7-NN12).

Nannofossils are present and moderately to well preserved within the topmost sample (320-U1335A$1 \mathrm{H}-1,40 \mathrm{~cm}$ ) with an assemblage dominated by abundant Gephyrocapsa spp., Calcidiscus leptoporus, and Florisphaera profunda. This sample is assigned to an undifferentiated Zone NP20-21 because of the presence of questionable Emiliania huxleyi. The top of Pseudoemiliania lacunosa in Sample 320-U1335A$1 \mathrm{H}-3,100 \mathrm{~cm}$, marks the top of Zone NN19. A continuous succession of nannofossil datums (Table T4) suggests that there is near-continuous stratigraphy through the Pliocene-Pleistocene. It was not possible to reliably pick some of the additional datums within Zone NN19 that are based on size changes within the genus Gephyrocapsa. Because of relatively low sedimentation rates, however, several wellcalibrated datums that are separated by 10-100 k.y. within the lower Pleistocene-Pliocene interval are found at the same level in the present sectionresolution biostratigraphy (the top of Calcidiscus macintyrei at $1.61 \mathrm{Ma}$ together with the top of Discoaster brouweri at $1.93 \mathrm{Ma}$, the top of Discoaster pentaradiatus at 2.39 Ma with the top of Discoaster surculus at $2.49 \mathrm{Ma}$, the top of Sphenolithus spp. at 3.54 Ma with the top of Reticulofenestra pseudoumbilicus at $3.70 \mathrm{Ma}$, the top of Ceratolithus acutus at $5.04 \mathrm{Ma}$ with the top of Ceratolithus rugosus at $5.05 \mathrm{Ma}$, and the top of Triquetrorhabdulus rugosus at $5.28 \mathrm{Ma}$ with the base of $C$. acutus at $5.35 \mathrm{Ma}$ ). Very low abundances or absence of some additional marker species also prevented the use of their associated datums, including the top of Helicosphaera sellii, base of common Discoaster triradiatus, and base of Ceratolithus larrymayeri. The Miocene/Pliocene boundary (5.33 Ma) is located between the datums at the top of T. rugosus at $5.28 \mathrm{Ma}$ and base of C. acutus at $5.35 \mathrm{Ma}$, which both occur between Samples 320-U1335A-3H-CC and 4H-1, $66 \mathrm{~cm}$.

Nannofossil datums within the $46 \mathrm{~m}$ sequence of upper Miocene nannofossil ooze indicate a sedimenta- 
tion rate of $\sim 7 \mathrm{~m} / \mathrm{m} . y$. , similar to that within the Pliocene-Pleistocene interval (Fig. F14). Additional datums within Zone NN11, based on Nicklithus amplificus (top of N. amplificus and abundance crossover of $N$. amplificus/T. rugosus), were not possible to place because of the very rare occurrence of $N$. amplificus, which was only observed in Sample 320-U1335A-4H$6,66 \mathrm{~cm}$. Catinaster calyculus was absent. The cooccurrence of the base of Discoaster hamatus, base of Catinaster coalitus, and top of Coccolithus miopelagicus datums between Samples 320-U1335A-7H-4, $82 \mathrm{~cm}$, and $7 \mathrm{H}-6,79 \mathrm{~cm}$, marks the Zone NN8/NN9 boundary. Sedimentation rates also remain low $(\sim 7 \mathrm{~m} / \mathrm{m}$.y. $)$ in the lower part of the upper Miocene. The middle/ late Miocene boundary $(11.60 \mathrm{Ma})$ is placed close to the top common Discoaster kugleri (11.58 Ma), which occurs at $72.8 \mathrm{~m}$ CSF between Samples 320-U1335A$8 \mathrm{H}-4,90 \mathrm{~cm}$, and $8 \mathrm{H}-6,90 \mathrm{~cm}$.

Sedimentation rates are significantly higher below the middle/late Miocene boundary: $\sim 18 \mathrm{~m} / \mathrm{m}$.y. to $\sim 19 \mathrm{Ma}$, increasing to $\sim 33 \mathrm{~m} / \mathrm{m}$.y. from $\sim 19 \mathrm{Ma}$ through to the base of the hole in the upper Oligocene $(\sim 25 \mathrm{Ma})$. Almost all lower and middle Miocene datums and nannofossil zones were recognized, although the Zone NN4/NN5 boundary could not be accurately determined because of the absence of $\mathrm{He}$ licosphaera ampliaperta in these sediments. The additional datum of the base of Discoaster petaliformis (15.70 Ma) (Discoaster signus in Raffi et al., 2006) was, however, recognized between Samples 320-U1335A$16 \mathrm{H}-\mathrm{CC}$ and $17 \mathrm{H}-2,70 \mathrm{~cm}$, within the upper part of Zone NN4. At Site U1335 there is a short interval at the base of Zone NN4 between the base common occurrence of Sphenolithus heteromorphus and the top common occurrence of Sphenolithus belemnos, where both of these taxa are pre.sent at low abundances (cf. Young, 1999), some of which may represent intergrading morphologies between these two morphotypes. The intra-Zone NN2 bioevents of the base of H. ampliaperta and the abundance crossover of Helicosphaera euphratis/Helicosphaera carteri could not be recognized in this succession because of the absence of $H$. ampliaperta and patchy distribution of other Helicosphaera species. The additional event of the top acme of Triquetrorhabdulus carinatus (Raffi et al., 2006) is, however, easily identified toward the base of Zone NN2. Although the placement of the Zone NN1/NN2 boundary, as defined by the base of Discoaster druggii, is usually problematic because of the rarity and poorly defined nature of this taxon (Young, 1999), D. druggii is conspicuously present in Samples 320-U1335A-36H-CC and 37X-2, $90 \mathrm{~cm}$. These two samples also bracket the base of Sphenolithus disbelemnos, which has been used as a proxy for the Zone NN1/NN2 boundary (Young, 1999); this may indicate that $D$. druggii has a short interval of increased abundance at the base of its range and may still be of some use in determining the Zone NN1/ NN2 boundary.

The placement of the Oligocene/Miocene boundary (23.0 Ma), based on the planktonic foraminifer event of the base of P. kugleri at $348.6 \mathrm{~m} \mathrm{CSF}$, is in good agreement with the topmost Oligocene nannofossil event, the top of $S$. delphix at $349.7 \mathrm{~m}$ CSF between Samples 320-U1335A-37X-6, $50 \mathrm{~cm}$, and 37X-CC. There are three nannofossil events closely spaced around the Zone NP25/NN1 boundary: top of Sphenolithus ciperoensis, abundance crossover of Triquetrorhabdulus longus/T. carinatus, and top common of Cyclicargolithus abisectus. At Sites U1332-U1335, there is no clear "acme" event of C. abisectus; however, it does appear to have a clear and consistent top occurrence, at least in the eastern equatorial Pacific, close to the Zone NP25/NN1 boundary at the same level as the top acme calibration on the ODP Leg 199 timescale (Lyle, Wilson, Janecek, et al., 2002).

\section{Radiolarians}

The radiolarian stratigraphy at Site U1335 (Fig. F13; Table T5) spans the interval from Zone RN14 (lower Pleistocene) in Core 320-U1335-1H to the uppermost part of Zone RP21 (upper Oligocene) in the upper part of Core 320-U1335-44X (Samples 320U1335-44X-2, 105-107 cm, and 44X-4, 105-107 cm) (Tables T6, T7). The assemblages are generally well preserved throughout the recovered section; however, there are several intervals in which the preservation is only moderate. Samples with moderate preservation are most commonly found in the upper part of the section within Core 320-U1335-7H (lowermost upper Miocene) and in Cores 320-U1335-12H through $15 \mathrm{H}$ (middle Miocene), $25 \mathrm{H}$ through $29 \mathrm{H}$ (lower Miocene), and $37 \mathrm{H}$ and $38 \mathrm{H}$ (lowermost lower Miocene). This intermittent decrease in preservation is not clearly associated with any particular lithologic observation, such as the occurrence of turbidites or color changes. Nor is it associated with reworked older microfossils. Reworked older radiolarians are found mixed within younger assemblages most commonly in Cores 320-U1335-1H through $4 \mathrm{H}$, an interval with lower average accumulation rates (Fig. F14). In the remainder of the section, reworking of older microfossils is minor and found mainly in the lower middle Miocene part of the section.

The lack of a clear association of preservation and reworking with the occurrence of turbidites in the section (see "Lithostratigraphy") suggests that the 
material transported by these turbidites was nearly the same age as the levels at which they were deposited. However, the frequent occurrence of these turbidites could have an effect on the upper limit (last occurrence) of some of the stratigraphically important species (Table T5) by extending their apparent range upsection. Therefore, the first occurrence of a species is generally considered a more reliable datum in Zones RP18 through RP20.

In the expanded lower Miocene and Oligocene section it becomes clear that some of the species used in the radiolarian stratigraphy are discontinuous in their appearance. This was noticed in the Leg 199 material in such common and robust species as Acrocubus octopylus and Didymocyrtis tubaria (Nigrini et al., 2006). In Site U1335 we also see the discontinuous occurrences of these species, as well as in Dorcadospyris ateuchus and Lychnocanoma elongata. This may reflect large variation in the abundance of these species with time and changing ecologic conditions. However, there is also the possibility that at least some of these intermittent disappearances of a species may reflect genetic changes in the lineage that give rise to either "iterative evolution" or changing ecological preferences.

As at Sites U1331-U1334, the lower part of the succession (Cores 320-U1335A-40X through the upper part of $44 \mathrm{X}$ ) has only moderate radiolarian preservation and the lowermost samples (Samples 320U1335A-44X-CC through 45X-CC) are completely barren of radiolarians.

\section{Diatoms}

Diatoms were examined in core catcher samples from Hole U1335A and represent the interval from the Fragilariopsis reinholdii Zone through the Rocella gelida Zone of Barron $(1985,2006)$ and Barron et al. (2006). Diatoms range in abundance from rare to abundant. Diatom preservation is variable but generally moderate to good. Several intervals as discussed below reflect much poorer preservation, whereas others are better. Typical zonal indicators are not always present, requiring the use of secondary markers for zonal placement. Specific zonal assignments are as follows.

Sample 320-U1335A-1H-CC contains a Pleistocene diatom assemblage typified by Actinocyclus ellipticus, Asteromphalus elegans, Azpeitia nodulifera, Hemidiscus cuneiformis, Nitzschia fossilis, $F$. reinholdii, Thalassiosira eccentrica, and Fragilariopsis doliolus. The occurrences of $F$. reinholdii with $F$. doliolus allows placement of this sample into the $F$. reinholdii Zone.

Sample 320-U1335A-2H-CC is assigned to the Nitzschia jouseae Zone based on the occurrence of $N$. jouseae without Rhizosolenia praebergonii. The $R$. praebergonii Zone was not observed as a result of sample spacing.

The Thalassiosira convexa Zone is represented in Samples 320-U1335A-3H-CC and 4H-CC. Sample 320$\mathrm{U} 1335 \mathrm{~A}-3 \mathrm{H}-\mathrm{CC}$ is assigned to the upper portion of this zone based on the occurrences of Fragilariopsis cylindrica, T. convexa var. aspinosa, and Thalassiosira oestrupii without $N$. jouseae. The suggestion of this sample being equivalent to the upper portion of this zone is based on the presence of specimens transitional between $F$. cylindrica and $N$. jouseae. Sample $320-\mathrm{U} 1335 \mathrm{~A}-4 \mathrm{H}-\mathrm{CC}$ is assigned to Subzone A of the T. convexa Zone based on the occurrences of Thalassiosira praeconvexa, Nitzschia miocenica, T. convexa var. aspinosa, and Asterolampra acutiloba. The N. miocenica Zone was not observed because of sample spacing.

The occurrences of Nitzschia porteri and F. cylindrica without $N$. miocenica allows placement of Sample U1335A-5H-CC into the N. porteri Zone. Thalassiosira burckliana was not observed in the sample, suggesting placement of the sample in Subzone B of the $N$. porteri Zone.

Sample 320-U1335A-6H-CC is assigned to the Thalassiosira yabei Zone based on the occurrences of $T$. yabei, A. ellipticus var. javanica, and A. nodulifera var. cyclopsa. T. burckliana was not observed in the sample, suggesting placement of the sample in Subzone A of the T. yabei Zone.

The last occurrence of Denticulopsis simonsenii was recognized to have a chronostratigraphic occurrence similar to that of Actinocyclus moronensis and as such was identified as a useful datum for determining the top of the A. moronensis Zone. The common occurrence of $D$. simonsenii in Sample 320-U1335A-7H-CC suggests placement of this sample in the $A$. moronensis Zone.

The co-occurrence of Craspedodiscus coscinodiscus and Coscinodiscus gigas var. diorama allows placement of Sample 320-U1335A-8H-CC in the C. coscinodiscus Zone. The occurrence of A. ellipticus var. spiralis and Rossiella praepaleacea without $H$. cuneiformis suggests placement in the middle portion of this zone.

Samples 320-U1335A-9H-CC and 10H-CC are assigned to the $C$. gigas var. diorama Zone. The zonal assignment of Sample 320-U1335A-9H-CC is tentative. This sample is characterized by the presences of D. simonsenii, Rossiella paleacea, Cavitatus jouseanus, C. coscinodiscus, Crucidenticula punctata, and C. gigas var. diorama. The absence of Coscinodiscus temperi var. delicata suggests placement in the $C$. gigas var. diorama Zone, whereas the absence of Cestodiscus pulchellus suggests placement in the younger C. coscinodiscus Zone. Sample 320-U1335A-10H-CC is as- 
signed to the C. gigas var. diorama Zone based on the occurrence of Annellus californicus and C. pulchellus without Coscinodiscus lewisianus.

Samples 320-U1335A-11H-CC and 12H-CC are assigned to the $C$. lewisianus Zone based on the occurrence of $C$. lewisianus. The occurrence of Thalassiosira tappanae in Sample 320-U1335A-12H-CC supports this zonal assignment and suggests that this sample is equivalent to the lower portion of this zone.

The interval from Samples 320-U1335A-13H-CC through $18 \mathrm{H}-\mathrm{CC}$ contains few to common diatoms with poor to moderate preservation. Cestodiscus peplum, the marker for the Coscinodiscus peplum/C. lewisianus boundary, was not observed. As such, zonal assignment for this interval is tentative. Samples 320-U1335A-13H-CC through $15 \mathrm{H}-\mathrm{CC}$ are assigned to the lowermost portion of the C. lewisianus Zone through Subzone B of the C. peplum Zone based on stratigraphic position. Zonal diagnostic species were not observed in this interval. The occurrence of $A$. californicus in Samples 320-U1335A-16H-CC and $17 \mathrm{H}-\mathrm{CC}$ allow placement of these samples into Subzone A of the C. peplum Zone. The occurrence of Cavitatus miocenica in Sample 320-U1335A-18H-CC suggests placement of this sample in Subzone B of the Crucidenticulopsis nicobarica Zone.

Sample 320-U1335A-19H-CC contains Crucidenticula kanayae, Coscinodiscus blysmos, C. jouseanus, Thalassiosira fraga, and C. lewisianus var. similis. The occurrences of $C$. kanayae and $C$. blysmos without $C$. miocenica suggest that this sample approximates the C. peplum/C. nicobarica Zonal boundary.

Samples 320-U1335A-20H-CC and 21H-CC are assigned to the $C$. nicobarica Zone. The occurrence of Raphidodiscus marylandicus and C. miocenica in Sample 320-U1335A-20H-CC suggests placement of this sample in the lower portion of Subzone B of the $C$. nicobarica Zone or older. The co-occurrence of $C$. lewisianus var. robustus and C. lewisianus var. similis in Sample 320-U1335A-21H-CC suggests assignment of this sample into the upper portion of Subzone A of the C. nicobarica Zone.

The zonal assignment for Sample 320-U1335A-22H$\mathrm{CC}$ is tentative given the minimal number of zonal indicators observed in this sample. The occurrence of Triceratium pileus suggests assignment to the lower portion of Subzone A of the C. nicobarica Zone or to the T. pileus Zone. Samples 320-U1335A-23H-CC and $24 \mathrm{H}-\mathrm{CC}$ are assigned to the T. pileus Zone based on the occurrence of Actinocyclus radionovae in both samples. The occurrence of Thalassiosira spinosa in Sample 320-U1335A-23H-CC supports this zonal assignment.
The occurrences of Coscinodiscus rhombicus and $T$. fraga in Samples 320-U1335A-25H-CC and 26H-CC allow assignment of these samples to the Craspedodiscus elegans Zone. Other species observed include $T$. spinosa, C. miocenica, and C. lewisianus.

Zonal assignments for Samples 320-U1335A-27H-CC through $30 \mathrm{H}-\mathrm{CC}$ are tentative, as this interval is characterized by diatoms with poor to moderate preservation. Diatom fragments are typical in this interval. Species observed include $C$. rhombicus, $C$. lewisianus, $C$. miocenica, and $A$. radionovae. The occurrence of Actinocyclus hajosiae in Sample 320U1335A-30H-CC suggests that this section is equivalent to the lower portion of this zone or upper portion of the Rossiella fennerae Zone. The absence of Bogorovia veniamini in this sample and the occurrence of B. veniamini in Sample 320-U1335A-31-CC stratigraphically below this interval supports the $C$. elegans Zone assignment for Sample 320-U1335A30H-CC.

The $R$. fennerae Zone is assigned to Samples 320U1335A-31H-CC through $36 \mathrm{H}-\mathrm{CC}$ based on the occurrence of $B$. veniamini with $R$. fennerae. Subzones were not differentiated within this interval given the amount of fragmentation. The assemblage is characterized by Coscinodiscus barronii, C. rhombicus, B. veniamini, $R$. fennerae, $C$. miocenica, and $C$. jouseanus. $R$. paleacea occurs in Section 320-U1335A-32H-CC, suggesting placement in the upper portion of this zone.

Samples 320-U1335A-37X-CC through 42X-CC are assigned to the $R$. gelida Zone based on the occurrence of $R$. gelida. The occurrence of Rocella schraderi in Sample 320-U1335A-40X-CC suggests that Samples 320-U1335A-37X-CC through 40X-CC are equivalent to the upper portion of this zone. The occurrence of C. lewisianus var. rhomboides and Craspedodiscus baronii without $R$. schraderi in Sample 320-U1335A-42X-CC suggests the equivalent of the lower portion of the zone.

Sample 320-U1335A-43X-CC is assigned to the B. veniamini Zone based on the occurrence of Rocella vigilans and Cestodiscus kugleri without $R$. gelida. Diatoms were not observed in Sample 320-U1335A-44X-CC.

\section{Planktonic foraminifers}

Micropaleontological samples from the core catchers were taken from both holes of Site U1335. Highresolution biostratigraphy was undertaken on additional samples from Hole U1335A (two per core). Planktonic foraminifer biostratigraphy indicates a nearly continuous succession of zones ranging from the Pleistocene (Zone PT1a) throughout the upper Oligocene (Zone O6) (Fig. F13), which agree well with calcareous nannofossil and radiolarian biostra- 
tigraphy (Fig. F14). Preservation and abundance of planktonic foraminifers are generally good from the Pliocene through Miocene with samples frequently containing $>70 \%$ planktonic foraminifers, but there are exceptions within this interval and lower preservation and abundances of planktonic foraminifers are recorded during the late Oligocene. The depths of the main datum biostratigraphic events and age estimates are shown in Table T8. Preservation and presence of planktonic foraminifers are shown in Table T9.

The topmost Samples 320-U1335A-1H-3, 100$102 \mathrm{~cm}$, and $1 \mathrm{H}-5,42-44 \mathrm{~cm}$, are assigned to the first Pleistocene Zone PT1a that is distinguished between the top of G. fistulosus in Sample 320-U1335A-1HCC and the top of Globorotalia (Truncorotalia) tosaensis. Accurate assignment of Zones PL1-PL6 is difficult because although planktonic foraminifers are abundant and assemblages are diverse (frequently $>20$ species), a number of age-diagnostic marker species were not found or were too rare to be employed as reliable datums (e.g., Globoturborotalita nepenthes, Globorotalia [Hirsutella] margaritae, and Dentoglobigerina altispira). Furthermore, in Core 320-U1335A-1H and Sample 320-U1335-2H-CC the $<250 \mu \mathrm{m}$ size fraction is composed almost entirely of planktonic foraminifer fragments. In these same cores there is also evidence of dissolution/fragmentation with only the "skeleton" of some species being preserved (i.e., individuals of the subgenus Menardella are frequently observed with only the keel and limbate sutures and missing walls of the final whorl chambers). Consequently, these assemblages are biased toward more robust taxa (i.e., Globorotalia tumida, Pulleniatina spp., and Sphaeroidinella dehiscens). In such cases, both primary datums and additional age-diagnostic species were employed to assign zones. Zone PL6 was identified between the LO of Globorotalia pseudomiocenica in Sample 320-U1335B-2H-CC (3.43 m CSF) and the top of G. fistulosus. Zones PL4-PL5 were identified between the top of Sphaeroidinellopsis seminulina in Sample 320-U1335A-3H-4, 38-40 cm, and the top of Globoturborotalita woodi and G. pseudomiocenica in Sample 320-U1335A-2H-2, 104-106 cm. It was not possible to further subdivide the zones because of the absence of the age-diagnostic taxon $D$. altispira within the high-resolution samples taken from Zones PL4 and PL5 in this sediment interval. Moreover, the last occurrence of this taxon, which is easily identifiable and often abundant, is recorded $\sim 20 \mathrm{~m}$ deeper in Holes U1335A and U1335B than expected based on previous calibration studies in the equatorial Pacific that utilize the top of $D$. altispira as a datum event to define the Zone PL4/PL5 boundary (Chaisson and Pearson, 1997) at 3.47 Ma. Zones
PL1-PL3 were identified between the base of $G$. tumida (Sample 320-U1335A-3H-CC; $28.13 \mathrm{~m} \mathrm{CSF}$ ) and the top of S. seminulina (Sample 320-U1335A-2H-4, 104-106 cm; $14.44 \mathrm{~m} \mathrm{CSF).} \mathrm{The} \mathrm{absence} \mathrm{or} \mathrm{rarity} \mathrm{of}$ G. (Hirsutella) margaritae and G. nepenthes prevented further subdivision. However, a number of supplementary age-diagnostic events were identified, including the base of S. dehiscens at 5.54 Ma (Chaisson and Pearson, 1997) and the top of Sphaeroidinellopsis kochi at $4.53 \mathrm{Ma}$ (Curry et al., 1995), indicating the presence of Zone PL1.

Upper Miocene Zone M14 was determined between the lowest occurrence of G. tumida in Section 320U1335A-3H-CC and the base of $G$. (Hirsutella) margaritae in Sample 320-U1335A-4H-CC. The first occurrence of Globorotalia plesiotumida is recorded in Sample 320-U1335A-6H-2, 38-40 cm, and defines the base of Zone M13b. Zones M13a and M12 were not divided because of the rare occurrence of Neogloboquadrina acostaensis toward the base of its stratigraphic range. Zone M11 was delimited by the top of Paragloborotalia mayeri (10.57 Ma) in Sample 320-U1335A-7H-6, 95-97 cm, and the base of Globoturborotalita decoraperta (11.49 Ma) in Section 320-U1335A-8H-CC, which falls just above the base of Zone M11. Above the last occurrence of Globorotalia (Fohsella) fohsi s.l. in Sample 320-U1335A-9H-2, 38-40 cm, is Zone M10 (N13). Zone M9b/N12 is defined by the total range of Globorotalia (Fohsella) fohsi robusta between Samples 320-U1335A-9H-4, 38-40 cm, and 11H-CC. Zone M9a/N12 was identified in Sample 320U1335A-12H-2, 38-40 cm, by the base of G. (Fohsella) fohsi s.l. The base of Zone N10 was defined by the first occurrence of Globorotalia (Fohsella) "praefohsi." Secondary datum events such as the tops of Clavatorella bermudezi (13.82 Ma), Globorotalia (Fohsella) peripheroronda (13.80 Ma), and Globorotalia praescitula (13.73 Ma) take place within Zone M7 (N10-N11). The base of Zone M7 (N10) is defined by the base of Globorotalia (Fohsella) peripheroacuta. The base of Praeorbulina sicana occurs in Sample 320U1335A-18H-CC, defining Zone M5, but further differentiation of Zones M5 and M6 was problematic given the absence of Praeorbulina glomerosa, Orbulina spp., and Globigerinatella insueta, which could be explained by the low preservation potential of these taxa. The latter may also account for the very shallow base of $C$. bermudezi recorded here. As a result, the exact position of some of the datums belonging to these zones might be slightly biased. The base of Globorotalia (Menardella) archeomenardii at $16.26 \mathrm{Ma}$ (Curry et al., 1995) was identified in Sample 320U1335A-16H-CC, indicating topmost Zone M5b or Zone M6/N9. The top of Catapsydrax dissimilis that defines the base of Zone M4 was difficult to deter- 
mine because of low abundance toward the top of its stratigraphic range, but it was identified in Sample 320-U1335B-20H-CC. The absence of $G$. insueta prevented accurate determination of the M2/M3 zonal boundary. The datum event marked by the top of Globoquadrina binaiensis (19.09 Ma) was identified in Sample 320-U1335A-20H-CC (185.19 m CSF) and falls toward the very top of the undifferentiated Zones M2-M3, higher than expected. Zone M1b was determined by the co-occurrence of P. kugleri, Paragloborotalia pseudokugleri, and Globoquadrina dehiscens between Samples 320-U1335A-28H-CC and 33H-CC. Zone M1a occurs between the bases of $G$. dehiscens in Sample 320-U1335A-33H-CC at $22.4 \mathrm{Ma}$ and $P$. kugleri in Sample 320-U1335A-37X-4, 136-138 cm, at $23.0 \mathrm{Ma}$. The Oligocene/Miocene boundary was also well defined in Hole U1335B between Samples 320U1335B-37X-CC and 38X-CC using the base of $P$. kugleri. The lowest zone defined is Zone $\mathrm{O} 6$ in the late Oligocene and the presence of $P$. pseudokugleri indicates that only the upper part of the zone is present.

\section{Benthic foraminifers}

Benthic foraminifers from core catcher samples were examined semiquantitatively in all holes at Site U1335. Benthic foraminifers occurred almost continuously, except in Sample 320-U1335B-3H-CC and several other samples in the early Miocene and late Oligocene. The occurrence of benthic foraminifers at this site is shown in Table T10.

From Samples 320-U1335A-1H-CC to 9H-CC (8.84$85.05 \mathrm{~m}$ CSF), Oridorsalis umbonatus, Cibicidoides mundulus, and Globocassidulina subglobosa are common with a few subordinate Anomalinoides sp. A, Gyroidinoides spp., Latcarinina pauperata, Melonis pompilioides, and Melonis barleeanum. A similar fauna is found between Samples 320-U1335B-1H-CC and 9H-CC (3.46-79.96 $\mathrm{m}$ CSF). Preservation of the foraminifer tests is moderate to good. Pliocene and middle Miocene taxa recorded here indicate lower bathyal and abyssal paleodepths (van Morkhoven et al., 1986).

Samples 320-U1335A-10H-CC through 44X-CC (104.56-417.80 m CSF) generally contain common O. umbonatus, C. mundulus, G. subglobosa, and Gyroidinoides spp. with a few subordinate Anomalinoides sp. A, Astrononion echolsi, L. pauperata, and Pullenia spp. in several horizons. Several samples in the lower part of the interval (early Miocene and late Oligocene) were barren of benthic foraminifers (Samples 320-U1335A-28H-CC, 29H-CC, and 37XCC; $265.99,275.59$, and $350.04 \mathrm{~m}$ CSF, respectively) or rare (Samples 320-U1335A-32H-CC, 33H-CC, and 44X-CC; 297.98, 313.51, and $394.90 \mathrm{~m}$ CSF, respectively), where present assemblages in these samples are often dominated by small individuals. Preservation of the foraminifer tests is moderate to good. Similar benthic foraminifer assemblages were also recognized in Hole U1335B (Samples 320U1335B-10H-CC through 45X-CC; 89.06-411.88 m CSF), including a number of barren or rare horizons of benthic foraminifers (Samples 320-U1335B-32HCC, 35H-CC, 36H-CC, and 43X-CC; 297.98, 326.87, 336.55 , and $394.90 \mathrm{~m}$, respectively); however, these were not always contemporaneous with those observed in Hole U1335A. These faunal compositions indicate lower bathyal and abyssal paleodepths during the middle Miocene to late Oligocene.

\section{Paleomagnetism}

We studied the paleomagnetism of sediments from Site U1335 with a primary focus on determining a preliminary magnetostratigraphy, which can be used to assist in dating the stratigraphic section. To accomplish this, we measured the natural remanent magnetization (NRM) of archive-half sections from 78 APC cores recovered from Holes U1335A and U1335B. Measurements were made along each section at $5 \mathrm{~cm}$ intervals before and after AF demagnetization at $20 \mathrm{mT}$. Many sections were measured at 2.5 $\mathrm{cm}$ intervals following $20 \mathrm{mT} \mathrm{AF}$ demagnetization, as we found higher resolution data to be more useful than measuring the 5,10 , or $15 \mathrm{mT}$ demagnetization steps with ordinary resolution (see "Paleomagnetism" in the "Site U1334" chapter). For some of the archive-half sections from deeper intervals in Hole U1335B, we only measured the NRM before demagnetization because of their extremely weak magnetizations. No XCB cores were measured at this site.

We processed the paleomagnetic data by removing measurements made within $5 \mathrm{~cm}$ of section ends and data from disturbed intervals (Table T11). Cleaned data are presented in Tables T12, T13, T14, and T15 and in Figures F7 and F15.

Azimuthal core orientation was determined solely by correlating distinct reversals patterns as recorded by the paleomagnetic declination in each hole with the geomagnetic polarity timescale (GPTS) (See "Paleomagnetism" in the "Methods" chapter and "Paleomagnetism" in the "Site U1331" chapter). This process is aided by detailed biostratigraphic age constraints, which significantly limit the range of possible correlations with the GPTS (see "Biostratigraphy"). Once we had confidently identified a unique, unambiguous reversals pattern, the mean paleomagnetic directions for each core were calculated using Bingham statistics (Table T16) with 
the same procedure described in "Paleomagnetism" in the "Site U1332" chapter. Subsequently the data were reoriented so that normal and reversed polarity intervals had declinations of $\sim 0^{\circ}$ and $\sim 180^{\circ}$, respectively (see "Paleomagnetism" in the "Site U1331" chapter). Reoriented declinations are provided for Holes U1335A and U1335B in Tables T13 and T15, respectively, for the data collected after AF demagnetization at $20 \mathrm{mT}$.

We measured magnetic properties of 257 discrete paleomagnetic samples. Of these, 70 samples were subjected to progressive AF demagnetization up to $60 \mathrm{mT}$. Remanence measurements and characteristic remanent magnetization (ChRM) directions computed using principal component analysis (PCA) are given in Tables T17 and T18, respectively. Magnetic susceptibilities and masses, along with volumes estimated using MAD data (see "Physical properties"), are given in Table T19. This table also includes magnetic susceptibilities from the whole-core data for the depth intervals corresponding to that of the discrete samples, which is useful for checking the scale factor, $0.68 \times 10^{-5}$ SI (see "Paleomagnetism" in the "Methods" chapter), for converting the whole-core raw susceptibility meter measurements into volumenormalized susceptibility values.

\section{Results}

Downhole variations in paleomagnetic data from split cores and discrete samples and magnetic susceptibility from whole-core and discrete samples are shown in Figures F7 and F15. The most prominent feature of the records is the magnetic intensity and susceptibility low that occurs between $\sim 70$ and $110 \mathrm{~m}$ and $\sim 210$ and $410 \mathrm{~m} \mathrm{CSF}$, referred to as the magnetic-low zone. We could not retrieve any reliable paleomagnetic directions from the magneticlow zone because the remanent magnetic intensity of the zone after $20 \mathrm{mT}$ AF demagnetization is on the order of $10^{-5} \mathrm{~A} / \mathrm{m}$, which is comparable to the noise level of the super-conducting rock magnetometer onboard the JOIDES Resolution (see "Paleomagnetism" in the "Methods" chapter). Similar to Site U1334, the magnetic-low zone can be attributed to reduction diagenesis (see "Paleomagnetism" in the "Site U1334" chapter).

The drilling overprint was generally weak for Site U1335 cores when nonmagnetic core barrels were used (Cores 320-U1335A-1H through $16 \mathrm{H}$ and 320U1335B-1H through 19H). This is evidenced by relatively shallow inclinations observed before demagnetization (Figs. F7, F15). In contrast, cores collected with steel core barrels are highly overprinted, as noted by the steep inclinations prior to demagnetization (Figs. F7, F15), which is similar to those observed at Sites U1333 (see Fig. F17 in the "Site U1333" chapter) and U1334 (see Figs. F16, F17, and F18 in the "Site U1334" chapter). Regardless of which type of core barrel was used, shallow inclinations and distinct reversal patterns in the declinations were observed after $20 \mathrm{mT}$ demagnetization, except within the magnetic-low zone. In the magnetic-low zone, the overprint appears more severe, which might be related to mineralogy (replacement of the primary iron oxides with iron sulfides). Similar to Site U1334, inclinations remain steep within the magnetic-low zone even after $20 \mathrm{mT}$ demagnetization, in spite of associated large decrease in the remanent intensity (Figs. F7, F15), indicating that steel core barrels have completely remagnetized these sediments.

Discrete sample demagnetization data indicate that the ChRM of the sediments can be resolved by AF demagnetization above 5-15 mT (Fig. F16) except for samples from the magnetic-low zone. We interpret this ChRM to be the primary depositional remanent magnetization. Similar to the Site U1334 samples, many of the Site U1335 samples have poorly resolved ChRM directions (scattered directions along a linear demagnetization path in the orthogonal demagnetization plot) due to weak magnetization of Site U1335 sediments. Nonetheless the ChRM declinations agree well with those of coeval intervals of the archive-half measurements (Fig. F15), indicating that the declinations from the split cores after $20 \mathrm{mT}$ demagnetization provide a reliable indicator of the ChRM of the sediments.

\section{Magnetostratigraphy}

The cleaned paleomagnetic data provide a series of distinct $\sim 180^{\circ}$ alternations in declination except for the magnetic-low zone. When combined with biostratigraphic age constraints (see "Biostratigraphy"), the data give a continuous magnetostratigraphy from Chrons $\mathrm{C} 1 \mathrm{n}(0-0.781 \mathrm{Ma})$ to C5n.2n (9.987-11.040 Ma) from 0 to $65.95 \mathrm{~m} \mathrm{CSF}$ in Hole U1335A and from Chrons C1n to C5r.1n (11.118-11.154 Ma) from 0 to $66.225 \mathrm{~m}$ CSF in Hole U1335B. Below the bottom of the first magnetic-low zone ( 70-110 $\mathrm{m} \mathrm{CSF})$, the magnetostratigraphy is again interpretable downhole: Chrons C5Br (15.16015.974 Ma) to C6n (18.748-19.722 Ma) from 155.35 to $208.40 \mathrm{~m}$ CSF in Hole U1335A and from Chron C5AAn (13.015-13.183 Ma) to Chron C5Er (18.524$18.748 \mathrm{Ma}$ ) from 107.95 to $202.60 \mathrm{~m}$ CSF in Hole U1335B. The magnetostratigraphy of the two holes is presented in Table T20 and Figures F17A, F17B, F18A, and F18B. The magnetostratigraphy could not be determined for the second magnetic-low zone (below $\sim 210 \mathrm{~m} \mathrm{CSF}$ ). 
Highlights of the magnetostratigraphy at Site U1335 are the identifications of (1) 123 reversals, (2) a previously observed cryptochron (C5Dr-1n) in both holes, and (3) 40 possible geomagnetic excursions (10 of these are recorded in both holes). The Site U1335 paleomagnetic record has high quality and resolution within the Miocene from 0 to $70 \mathrm{~m} \mathrm{CSF}$ and 110 to $210 \mathrm{~m} \mathrm{CSF}$, whereas it has poor quality in the magnetic-low zones. The resolution is high owing to the high sedimentation rates at Site U1335 throughout the Miocene (see Fig. F14). The highquality, high-resolution records made it possible to recognize the many potential excursions. Not all of the 40 potential excursions may be real geomagnetic features because a few are possibly associated with turbidites even though we excluded the intervals interpreted as turbidites. Considering the relatively high frequency of turbidites at this site, it is possible that some were not identified. Careful shore-based paleo- and rock magnetic investigations are necessary to confirm the reliability of these records.

\section{Geochemistry}

\section{Sediment gas sampling and analysis}

Headspace gas samples were taken at a frequency of one sample per core in Hole U1335A as part of the routine environmental protection and safety monitoring program. All headspace samples resulted in nondetectable levels of methane $\left(\mathrm{C}_{1} ;<2 \mathrm{ppmv}\right)$, with no higher hydrocarbons, consistent with the low organic carbon content of these sediments.

\section{Interstitial water sampling and chemistry}

A total of 48 interstitial water samples were collected using the whole-round squeezing method, 45 from Hole U1335A and 3 from Hole U1335B (Table T21). Chemical constituents were determined according to the procedures outlined in "Geochemistry" in the "Methods" chapter.

Chlorinity shows relatively little variability with depth, with values ranging from 554 to $565 \mathrm{mM}$ (Fig. F19). However, chlorinity values reveal a distinct increase from 554 to $565 \mathrm{mM}$ in the uppermost $40 \mathrm{~m}$ CSF, most clearly seen in previous IODP Sites U1332 and U1334, potentially reflecting the change from the more saline ocean at the Last Glacial Maximum to the present (Adkins and Schrag, 2003). Alkalinity shows little variability, with values ranging from 2.5 to $4.3 \mathrm{mM}$. Sulfate concentrations vary between 23 and $28 \mathrm{mM}$, with slightly decreasing values with depth. Dissolved phosphate concentrations are $\sim 2 \mu \mathrm{M}$ in the shallowest sample, decreasing to values $\sim 0.5 \mu \mathrm{M}$ in the uppermost $\sim 50 \mathrm{~m}$ CSF. Dissolved manganese shows three distinct peaks with concentrations of up to 44,13 , and $5 \mu \mathrm{M}$ between $\sim 0$ and 40, 50 and 80, and 150 and $210 \mathrm{~m} \mathrm{CSF}$, respectively. Generally, Mn peaks are sharp in the shallower part and broad at greater depth. Dissolved iron spikes to $6 \mu \mathrm{M}$ at $6 \mathrm{~m}$ CSF and peaks with concentrations $\sim 6 \mu \mathrm{M}$ between 90 and $170 \mathrm{~m} \mathrm{CSF}$ and between 190 and $370 \mathrm{~m}$ CSF. As with manganese, iron peaks become broader with increasing depth. Minima in dissolved Fe correspond to elevated Mn concentrations. The alternating pattern of dissolved $\mathrm{Mn}$ and $\mathrm{Fe}$ corresponds well to apparent color changes of the sediment (see "Lithostratigraphy").

Because of the relatively high sulfate concentrations, dissolved $\mathrm{Ba}$ concentrations are low and relatively homogeneous, with values below $2.2 \mu \mathrm{M}$. Concentrations of dissolved silicate increase with depth from $\sim 500$ to $\sim 820 \mu \mathrm{M}$.

Calcium and magnesium concentrations are relatively uniform, with values ranging from 9.5 to $12 \mathrm{mM}$ and from 44 to $51 \mathrm{mM}$, respectively (Fig. F19).

Lithium concentrations decrease from $\sim 26 \mu \mathrm{M}$ at the surface to $5 \mu \mathrm{M}$ at $\sim 300 \mathrm{~m}$ CSF. Lithium strongly increases below $300 \mathrm{~m}$ CSF toward basement. Strontium concentrations range between 82 and $250 \mu \mathrm{M}$, and this profile mirrors the lithium profile. Values increase from the top toward $200 \mathrm{~m} \mathrm{CSF}$, followed by a decrease toward basement. Boron concentrations range between 440 and $490 \mu \mathrm{M}$, slightly decreasing from the top to the basement.

\section{Bulk sediment geochemistry: major and minor elements}

At Site U1335, bulk sediment samples for minor and major element analyses were distributed over the core depth to characterize the major lithologic units (0-400 m CSF; Hole U1335A). We analyzed concentrations of silicon, aluminum, iron, manganese, magnesium, calcium, sodium, potassium, titanium, phosphorus, barium, copper, chromium, scandium, strontium, vanadium, yttrium, and zirconium by inductively coupled plasma-atomic emission spectroscopy (ICP-AES) (Table T22).

$\mathrm{SiO}_{2}$ ranges between 6 and $34 \mathrm{wt} \%$, with generally higher concentrations in the upper sediment. Similar patterns to $\mathrm{SiO}_{2}$ are displayed by $\mathrm{Al}_{2} \mathrm{O}_{3}$, with concentrations ranging from below detection limit to $3.6 \mathrm{wt} \%, \mathrm{TiO}_{2}(0.002-0.2 \mathrm{wt} \%), \mathrm{K}_{2} \mathrm{O}(0.1-1 \mathrm{wt} \%), \mathrm{Zr}$ (12-90 ppm), and Sc (up to $14 \mathrm{ppm}$ ).

Concentrations of $\mathrm{Fe}_{2} \mathrm{O}_{3}$ vary between 0.4 and $2.7 \mathrm{wt} \%$, following the general pattern of $\mathrm{SiO}_{2}$. Similar trends are also shown by $\mathrm{MnO}(0.04$ to $>0.2 \mathrm{wt} \%)$, $\mathrm{MgO}$ (0.3-1.5 wt\%), copper (below detection limit to $>140 \mathrm{ppm}$ ), and vanadium (up to $20 \mathrm{ppm}$ ). Peak con- 
centrations of $\mathrm{Mn}$ and $\mathrm{Cu}$ could not be quantified because they exceeded the calibrated range (values in brackets in Table T22).

Calcium $(\mathrm{CaO})$ ranges from 26 to $43 \mathrm{wt} \%$, with high values corresponding to the minima in $\mathrm{SiO}_{2}$ and $\mathrm{Al}_{2} \mathrm{O}_{3}$. Strontium concentrations are $>700 \mathrm{ppm}$, showing a similar pattern to that of $\mathrm{CaO}$. Barium concentrations are $>566 \mathrm{ppm}$, and $\mathrm{P}_{2} \mathrm{O}_{5}$ values range from below detection limit to $0.5 \mathrm{wt} \%$, showing minima at high $\mathrm{CaO}$ concentrations.

\section{Bulk sediment geochemistry: sedimentary inorganic and organic carbon}

$\mathrm{CaCO}_{3}$, IC, and TC concentrations were determined on sediment samples from Hole U1335A (Table T23; Fig. F5). Calcium carbonate concentrations ranged between 13 and $96 \mathrm{wt} \%$. In the uppermost $\sim 67 \mathrm{~m}$ $\mathrm{CSF}, \mathrm{CaCO}_{3}$ concentrations vary greatly between 12 and $87 \mathrm{wt} \%$. From 67 to $157 \mathrm{~m} \mathrm{CSF}$, calcium carbonate concentrations are consistently high (72-92 wt\%), and then $\mathrm{CaCO}_{3}$ concentrations show more variation, ranging between 37 and $89 \mathrm{wt} \%$ from 157 to $222 \mathrm{~m}$ CSF. Below $222 \mathrm{~m} \mathrm{CSF}, \mathrm{CaCO}_{3}$ concentrations are consistently high again (75-96 wt\%). Variations in $\mathrm{CaCO}_{3}$ concentrations correspond to lithostratigraphic changes (see "Lithostratigraphy").

TOC concentrations were determined by acidification (see "Geochemistry" in the "Methods" chapter) (Table T23; Fig. F5) and are very low throughout the sediment column, from below the detection limit to $0.10 \mathrm{wt} \%$ (Fig. F5).

\section{Physical properties}

Physical properties at Site U1335 were measured on whole cores, split cores, and discrete samples. WRMSL (GRA bulk density, magnetic susceptibility, $P$-wave velocity), thermal conductivity, and NGR measurements comprised the whole-core measurements. Compressional wave velocity measurements on split cores and MAD analyses on discrete core samples were made at a frequency of one per undisturbed section in Cores 320-U1335A-1H through $45 \mathrm{X}$. Compressional wave velocities were measured toward the bottom of sections. MAD analyses were located $10 \mathrm{~cm}$ downsection from carbonate analyses (see "Geochemistry"). Lastly, the Section Half Multisensor Logger (SHMSL) was used to measure spectral reflectance on archive section halves. The Ocean Optics sensor was used in place of the Minolta, and the resolution was reduced from 2.5 to $5 \mathrm{~cm}$ because of time constraints.

\section{Density and porosity}

Two methods were used to evaluate wet bulk density at Site U1335. GRA provided an estimate from whole cores (Fig. F20). MAD samples gave a second, independent measure of wet bulk density, along with providing dry bulk density, grain density, water content, and porosity from discrete samples (Table T24). MAD and GRA bulk density measurements display the same trends and are also similar in absolute values through the entire section (Fig. F21B). Crossplots of wet and dry bulk density versus interpolated GRA density (Fig. F22) show excellent correlation between MAD and GRA density data.

Generally, wet bulk density corresponds with changes in lithology. Wet bulk density is lowest in Unit I $\left(1.2-1.6 \mathrm{~g} / \mathrm{cm}^{3}\right)$, which contains the lowest calcium carbonate content. A prominent decrease in wet bulk density occurs at $58 \mathrm{~m} \mathrm{CSF}$, coinciding with an interval of clay-rich radiolarian ooze with diatoms within the major lithology of nannofossil ooze. Wet bulk density increases at the top of Unit II to values around $1.7 \mathrm{~g} / \mathrm{cm}^{3}$. A small increase in wet bulk density occurs around $215 \mathrm{~m}$ CSF to values close to $1.8 \mathrm{~g} / \mathrm{cm}^{3}$ in the lower portion of Unit II.

Variation in grain density in Hole U1335A generally matches changes in lithology (Fig. F21C). Grain density ranges from 2.0 to $3.0 \mathrm{~g} / \mathrm{cm}^{3}$ in Unit I. In Unit II the grain density of the sediments is much more uniform in comparison, averaging $2.7 \mathrm{~g} / \mathrm{cm}^{3}$ with variation up to $3.0 \mathrm{~g} / \mathrm{cm}^{3}$. This average reflects the carbonates that dominate Unit II (calcite $=2.7 \mathrm{~g} / \mathrm{cm}^{3}$ ).

Porosity ranges from $70 \%$ to $90 \%$ in Unit I, reflecting intervals of clayey radiolarian ooze within the major lithology of nannofossil ooze. In Unit II porosity gradually decreases to values of $50 \%-60 \%$ downhole over this $\sim 300 \mathrm{~m}$ section. Porosity and water content vary inversely with wet bulk density (Fig. F21A).

\section{Magnetic susceptibility}

Whole-core magnetic susceptibility measurements correlate well with the major differences in lithology in Unit I. In Unit II, magnetic susceptibility variability follows changes in geochemistry and reflectance spectroscopy. Loss of the magnetic susceptibility signal results from suboxic diagenesis that develops below $70 \mathrm{~m}$ CSF (Fig. F20). Magnetic susceptibility values range from $5 \times 10^{-5}$ to $20 \times 10^{-5} \mathrm{SI}$ in the upper portion of Unit I. In the lower portion of Unit I, magnetic susceptibility values increase to $25 \times 10^{-5}$ SI, which coincides with the occurrence of clayey radiolarian ooze within the major lithology of nannofossil ooze. Magnetic susceptibility values begin to 
decrease at the top of Unit II (64 m CSF) and then fall to values that are slightly negative $\left(-1 \times 10^{-5} \mathrm{SI}\right)$ in the zone of suboxic diagenesis as Fe reduction removes the ferromagnetic component of the sediment (see "Geochemistry"). Magnetic susceptibility values increase slightly and become highly variable ( 0 to $10 \times 10^{-5} \mathrm{SI}$ ) between 110 and $150 \mathrm{~m}$ CSF. Magnetic susceptibility values are higher in the interval from 160 to $200 \mathrm{~m} \mathrm{CSF}$, coinciding with a decrease in Fe reduction that is also accompanied by a color change from green to brown (see "Lithostratigraphy"). Below $200 \mathrm{~m}$ CSF the magnetic susceptibility signature is largely diamagnetic, with values close to zero, reflecting a return to Fe reduction in the lower section of Unit II. Magnetic susceptibility values increase to $15 \times 10^{-5} \mathrm{SI}$ at the base of Unit II.

\section{Compressional wave velocity}

\section{Shipboard results}

Whole-core $P$-wave logger (PWL) data and discrete velocity measurements made on split cores follow similar trends, with key transitions reflecting increasing compaction with depth and the transition from ooze to chalk that occurs deep in the section ( 220 m CSF) (Fig. F23). Discrete velocity measurements along the $x$-axis are in excellent agreement with PWL results, though $y$ - and $z$-axis measurements generally overestimate by $10 \mathrm{~m} / \mathrm{s}$ (Table T25; Fig. F23). Differences between whole-core and splitcore measurements possibly reflect the presence of water in the space between the core liner and sediment in the whole cores and the slight compaction of the sediment in the contact probe technique.

Velocities are between 1460 and $1490 \mathrm{~m} / \mathrm{s}$ in Unit I and the upper portion of Unit II. Below $200 \mathrm{~m} \mathrm{CSF}$, velocities begin to increase above $1500 \mathrm{~m} / \mathrm{s}$. At the base of Unit II, slightly below the described ooze/ chalk boundary (345 m CSF; see "Lithostratigraphy") velocities increase dramatically, reaching values of $1600-1800 \mathrm{~m} / \mathrm{s}$ at the bottom of Unit II.

\section{Postcruise correction}

The $x$-direction velocities at Site U1335 were determined using a liner thickness of $3.2 \mathrm{~mm}$, the correction that was initially applied at Site U1334 (see "Physical properties" in the "Site U1334" chapter). During the analysis of Hole U1337A cores, it was determined that high $x$-direction velocities do not result from thicker than expected core liner but instead are the result of using an incorrect value for the system delay associated with the contact probe (see "Physical properties" in the "Site 1337" chapter). Critical parameters used in this correction are system delay $=19.811 \mu \mathrm{s}$, liner thickness $=2.7 \mathrm{~mm}$, and liner delay $=1.26 \mu \mathrm{s}$. During the analysis of Hole U1337A cores, it also was determined that consistently low PWL velocities required the addition of a constant value that would produce a reasonable velocity of water $(\sim 1495 \mathrm{~m} / \mathrm{s})$ for the quality assurance/ quality control (QA/QC) liner (see "Physical properties" in the "Site U1337" chapter). These corrections have not been applied to the velocity data presented in this chapter.

\section{Natural gamma radiation}

NGR was measured on all cores at Site U1335 (Fig. F20). The highest NGR values are present at the seafloor ( 73 cps). NGR values decrease rapidly with depth in Unit I, reaching values of $3 \mathrm{cps}$ at the base of Unit I. In Unit II, NGR is very low ( 1-2 cps) with low variability to the base of the section.

\section{Thermal conductivity}

Thermal conductivity was measured on the third section of each core from Hole U1335A (Table T26). Thermal conductivity shows a strong dependence on porosity downhole through the succession (Figs. F24, F25). Decreased conductivity occurs with increasing porosity as increased interstitial spacing attenuates the applied current from the probe. Thermal conductivity ranges from 0.8 to $1.0 \mathrm{~W} /(\mathrm{m} \cdot \mathrm{K})$ in Unit I and increases to $1.1 \mathrm{~W} /(\mathrm{m} \cdot \mathrm{K})$ in the upper portion of Unit II. Below $200 \mathrm{~m} \mathrm{CSF}$, thermal conductivity increases to $1.2 \mathrm{~W} /(\mathrm{m} \cdot \mathrm{K})$ and again to $1.3 \mathrm{~W} /(\mathrm{m} \cdot \mathrm{K})$ below $280 \mathrm{~m}$ CSF. These depths also coincide with increased $P$-wave velocity and decreased porosity. Below 380 m CSF, thermal conductivity decreases, possibly resulting from increasing fractures in the sediment core (see "Lithostratigraphy").

\section{Reflectance spectroscopy}

Spectral reflectance was measured on split archivehalf sections from all three holes using the Ocean Optics sensor with the SHMSL (Fig. F26). L* variations correspond to pronounced lithologic changes, the main example being the interval of clay-rich radiolarian ooze within the lower portion of Unit I ( $\sim 60 \mathrm{~m} \mathrm{CSF}$ ) where $\mathrm{L}^{*}$ values drop from $\sim 90$ to $\sim 30$. Variations in $\mathrm{a}^{*}$ (green-red) and $\mathrm{b}^{*}$ (blue-yellow) reflect changes in lithology but also covary with changes in magnetic susceptibility, as color change in these cores is largely driven by pore water geochemistry below $70 \mathrm{~m}$ CSF (see "Geochemistry"). In Unit I both $\mathrm{a}^{*}$ and $\mathrm{b}^{*}$ are relatively high (4 and 15 , respectively). Below $70 \mathrm{~m} \mathrm{CSF}$, both parameters drop to minimum values reflecting color change in the interval of iron reduction. 


\section{Stratigraphic correlation and composite section}

Special Task Multisensor Logger (STMSL) data were collected at $5 \mathrm{~cm}$ intervals from Hole U1335B and compared to the WRMSL data obtained at $2.5 \mathrm{~cm}$ resolution from Hole U1335A. In this way we monitored drilling in Hole U1335B in real time to maximize the opportunity for the recovery and construction of a stratigraphically complete composite section. The overall good to excellent overlap between Holes U1335A and U1335B did not require drilling a third hole.

The correlation was refined once magnetic susceptibility and GRA density data were available at $2.5 \mathrm{~cm}$ resolution from the WRMSL, and NGR and color reflectance data were available from the NGR track and the SHMSL (see "Physical properties"). Visual inspection of cores, comparison with core imagery, and biostratigraphic datums were used to establish and verify hole to hole correlation where track data lacked clearly identifiable features. Magnetic susceptibility and GRA density proved most useful for correlating between holes at Site U1335 (Figs. F27, F28). Features in the magnetic susceptibility and GRA density are well aligned between Holes U1335A (337 m CSF) and U1335B (344 m CSF) to $2398 \mathrm{~m}$ CCSF-A. Flow-in at the bottom half of Core 320-U1335A-16H between Sections $320-\mathrm{U} 1335 \mathrm{~A}-16 \mathrm{H}-4$ and $16 \mathrm{H}-7$ (146.4-151.46 m CSF) made it impossible to construct a complete stratigraphic section below $165.15 \mathrm{~m}$ CCSF-A and required appending the remainder of the section. Between $\sim 230$ and $\sim 398$ m CCSF-A, GRA density data allowed confident alignment of cores despite very low magnetic susceptibility values. The section below 398 m CCSF-A was mostly XCB-cored, lacked clearly identifiable features, and had to be appended for these reasons.

Offsets and composite depths are listed in Table T27. Following construction of the composite depth section for Site U1335, a single spliced record was assembled for the aligned cores to Section 320U1335B-37H-6 at $398.15 \mathrm{~m}$ CCSF-A (top panels of Figs. F27, F28). The sections of core used for the splice are identified in Table T28 and displayed in Figures F27 and F28.

We avoided intervals with significant disturbance or distortion and missing intervals where whole-round samples for interstitial water chemistry were taken (see "Paleomagnetism;" Table T11). The Site U1335 splice can be used as a sampling guide to recover a single sedimentary sequence from 0 to $398 \mathrm{~m}$ CCSFA with gaps between 165 and $166 \mathrm{~m}$ CCSF-A, although it is advisable to overlap a few decimeters from different holes when sampling to accommo- date anticipated ongoing development of the depth scale. Stretching and compression of sedimentary features in aligned cores indicates distortion of the cored sequence. Because much of the distortion occurs within individual cores on scales of $<9 \mathrm{~m}$, it was not possible to align every single feature in the magnetic susceptibility, GRA, NGR, and color reflectance records. However, at crossover points along the splice (Table T28), care was taken to align highly identifiable features from cores in each hole.

A growth factor of 1.16 is calculated by linear regression for all holes at Site U1335, indicating a 16\% increase in CCSF-A relative to CSF depth (Fig. F29). We used this value to calculate CCSF-B, the compressed composite depth presented in Table T27 to calculate sedimentation rates and aid in the calculation of mass accumulation rates.

\section{Sedimentation rates}

All the principal biostratigraphic datums and a set of 71 paleomagnetic reversals (restricted to the APCcored section of the site) are defined in Holes U1335A and U1335B (Table T29; see "Biostratigraphy" and "Paleomagnetism") and were used in establishing age control (Fig. F14). Paleomagnetic reversals were used to calculate the average linear sedimentation rates (LSRs) for the upper $200 \mathrm{~m}$ of the section at Site U1335 on CCSF-B depth scale, as depicted in Figure F14. Below $200 \mathrm{~m}$ CCSF-B all available biostratigraphic datums were used to calculate the average LSRs.

LSRs at Site U1335 are high, $25 \mathrm{~m} / \mathrm{m}$.y. on the average throughout the late Oligocene and early Miocene. Sedimentation rates decrease to $17 \mathrm{~m} / \mathrm{m}$.y. in the middle early Miocene and drop to $6 \mathrm{~m} / \mathrm{m}$.y. in late to middle Miocene to recent (Fig. F14).

\section{Downhole measurements}

\section{Heat flow}

Five APCT-3 downhole temperature measurements in Hole U1335B ranged from $1.64^{\circ} \mathrm{C}$ at $22.3 \mathrm{~m}$ to $2.22^{\circ} \mathrm{C}$ at $98.3 \mathrm{~m}$ (Table T30), giving a low geothermal gradient of $7.5^{\circ} \mathrm{C} / \mathrm{km}$ (Fig. F30). The bottom water temperature was $1.469^{\circ} \mathrm{C}$, based on the average of the minimum temperature in the five APCT- 3 temperature profiles. Thermal conductivity under in situ conditions was estimated from laboratorydetermined thermal conductivity using the method of Hyndman et al. (1974) (see "Physical properties" in the "Methods" chapter). The calculated in situ values are up to $2.5 \%$ less than the measured laboratory values. Thermal resistance was then calculated by cumulatively adding the inverse of the in situ 
thermal conductivity values over depth intervals downhole (Fig. F30). A heat flow of $7.0 \mathrm{~mW} / \mathrm{m}^{2}$ was obtained from the linear fit between temperature and thermal resistance (Fig. F30) (Pribnow et al., 2000), which is a low value compared to nearby sites in the global heat flow database and an order of magnitude lower that the heat flow at Site U1332.

\section{References}

Adkins, J.F., and Schrag, D.P., 2003. Reconstructing Last Glacial Maximum bottom water salinities from deep-sea sediment pore fluid profiles. Earth Planet Sci. Lett., 216:109-123. doi:10.1016/S0012-821X(03)00502-8

Amante, C., and Eakins, B.W., 2008. ETOPO1 1 Arc-Minute Global Relief Model: Procedures, Data Sources and Analysis: Washington, DC (DOC/NOAA/NESDIS/NGDC).

Barron, J.A., 1985. Late Eocene to Holocene diatom biostratigraphy of the equatorial Pacific Ocean, Deep Sea Drilling Project Leg 85. In Mayer, L., Theyer, F., Thomas, E., et al., Init. Repts. DSDP, 85: Washington, DC (U.S. Govt. Printing Office), 413-456. doi:10.2973/ dsdp.proc.85.108.1985

Barron, J.A., 2006. Diatom biochronology for the Early Miocene of the Equatorial Pacific. Stratigraphy, vol. 2, no. 4, 281-309.

Barron, J.A, Fourtanier, E., and Bohaty, S.M., 2006, Oligocene and earliest Miocene diatom biostratigraphy of ODP Leg 199, Site 1220, Equatorial Pacific., In Wilson, P.A., Lyle, M., Janecek, T.R., and Firth, J.V. (Eds.) Proceedings of the Ocean Drilling Program, Scientific Results Volume 199, 1-25.

Billups, K., Pälike, H., Channell, J.E.T., Zachos, J.C., and Shackleton, N.J., 2004. Astronomic calibration of the late Oligocene through early Miocene geomagnetic polarity time scale. Earth Planet. Sci. Lett., 224(1-2):3344. doi:10.1016/j.epsl.2004.05.004

Busch, W.H., Vanden Berg, M.D., and Masau, P.E., 2006. Velocity and density of Paleogene equatorial sediments: variation with sediment composition. In Wilson, P.A., Lyle, M., and Firth, J.V. (Eds.), Proc. ODP, Sci. Results, 199: College Station, TX (Ocean Drilling Program), 131. doi:10.2973/odp.proc.sr.199.226.2006

Cande, S.C., LaBrecque, J.L., Larson, R.L., Pitmann, W.C., III, Golovchenko, X., and Haxby, W.F., 1989. Magnetic Lineations of the World's Ocean Basins. AAPG Map Ser., 13.

Chaisson, W.P., and Pearson, P.N., 1997. Planktonic foraminifer biostratigraphy at Site 925: middle MiocenePleistocene. In Shackleton, N.J., Curry, W.B., Richter, C., and Bralower, T.J. (Eds.), Proc. ODP, Sci. Results, 154: College Station, TX (Ocean Drilling Program), 3-31. doi:10.2973/odp.proc.sr.154.104.1997

Coxall, H.K., Wilson, P.A., Pälike, H., Lear, C.H., and Backman, J., 2005. Rapid stepwise onset of Antarctic glaciation and deeper calcite compensation in the Pacific Ocean. Nature (London, U. K.), 433(7021):53-57. doi:10.1038/nature03135
Curry, W.B., Shackleton, N.J., Richter, C., et al., 1995. Proc. ODP, Init. Repts., 154: College Station, TX (Ocean Drilling Program). doi:10.2973/odp.proc.ir.154.1995

Engebretson, D.C., Cox, A., and Gordon, R.G., 1985. Relative Motions between Oceanic and Continental Plates in the Pacific Basin. Spec. Pap.-Geol. Soc. Am., 206.

Hays, J.D., et al., 1972. Init. Repts. DSDP, 9: Washington, DC (U.S. Govt. Printing Office). doi:10.2973/ dsdp.proc.9.1972

Holbourn, A., Kuhnt, W., Schulz, M., and Erlenkeuser, H., 2005. Impacts of orbital forcing and atmospheric $\mathrm{CO}_{2}$ on Miocene ice-sheet expansion. Nature (London, U.K.), 438(7067):483-487. doi:10.1038/nature04123

Hyndman, R.D., Erickson, A.J., and Von Herzen, R.P., 1974. Geothermal measurements on DSDP Leg 26. In Davies, T.A., Luyendyk, B.P., et al., Init. Repts. DSDP, 26: Washington, DC (U.S. Govt. Printing Office), 451-463. doi:10.2973/dsdp.proc.26.113.1974

Knappenberger, M., 2000. Sedimentation rates and Pacific plate motion calculated using seismic cross sections of the Neogene equatorial sediment bulge [M.Sc. thesis]. Boise State Univ., Idaho.

Koppers, A.A.P., Phipps Morgan, J., Morgan, J.W., and Staudigel, H., 2001. Testing the fixed hotspot hypothesis using ${ }^{40} \mathrm{Ar} /{ }^{39} \mathrm{Ar}$ age progressions along seamount trails. Earth Planet. Sci. Lett., 185(3-4):237-252. doi:10.1016/ S0012-821X(00)00387-3

Lear, C.H., Rosenthal, Y., Coxall, H.K., and Wilson, P.A., 2004. Late Eocene to early Miocene ice sheet dynamics and the global carbon cycle. Paleoceanography, 19(4):PA4015. doi:10.1029/2004PA001039

Lear, C.H., Bailey, T.R., Pearson, P.N., Coxall, H.K., and Rosenthal, Y., 2008. Cooling and ice growth across the Eocene-Oligocene transition. Geology, 36(3):251-254. doi:10.1130/G24584A.1

Lind, I.L., Janecek, T.R., Krissek, L.A., Prentice, M.L., and Stax, R., 1993. Color bands in Ontong Java Plateau carbonate oozes and chalks. In Berger, W.H., Kroenke, L.W., Mayer, L.A., et al., Proc. ODP, Sci. Results, 130: College Station, TX (Ocean Drilling Program), 453-470. doi:10.2973/odp.proc.sr.130.007.1993

Lyle, M.W., Pälike, H., Moore, T.C., Mitchell, N., and Backman, J., 2006. Summary Report of $R / V$ Roger Revelle Site Survey AMATO3 to the IODP Environmental Protection and Safety Panel (EPSP) in Support for Proposal IODP626: Southampton, U.K. (Univ. Southampton). http:// eprints.soton.ac.uk/45921/

Lyle, M., Wilson, P.A., Janecek, T.R., et al., 2002. Proc. ODP, Init. Repts., 199: College Station, TX (Ocean Drilling Program). doi:10.2973/odp.proc.ir.199.2002

Mayer, L.A., Shipley, T.H., Theyer, F., Wilkens, R.H., and Winterer, E.L., 1985. Seismic modeling and paleoceanography at Deep Sea Drilling Project Site 574. In Mayer, L., Theyer, F., Thomas, E., et al., Init. Repts. DSDP, 85: Washington, DC (U.S. Govt. Printing Office), 947-970. doi:10.2973/dsdp.proc.85.132.1985

Miller, K.G., Wright, J.D., and Fairbanks, R.G., 1991. Unlocking the ice house: Oligocene-Miocene oxygen isotopes, eustasy, and margin erosion. J. Geophys. Res., 96(B4):6829-6848. doi:10.1029/90JB02015 
Müller, R.D., Roest, W.R., Royer, J.-Y., Gahagan, L.M., and Sclater, J.G., 1997. Digital isochrons of the world's ocean floor. J. Geophys. Res., 102(B2):3211-3214. doi:10.1029/96JB01781

Nigrini, C., Sanfilippo, A., and Moore, T.C., Jr., 2006. Cenozoic radiolarian biostratigraphy: a magnetobiostratigraphic chronology of Cenozoic sequences from ODP Sites 1218, 1219, and 1220, equatorial Pacific. In Wilson, P.A., Lyle, M., and Firth, J.V. (Eds.), Proc. ODP, Sci. Results, 199: College Station, TX (Ocean Drilling Program), 1-76. doi:10.2973/odp.proc.sr.199.225.2006

Pälike, H., Lyle, M.W., Ahagon, N., Raffi, I., Gamage, K., and Zarikian, C.A., 2008. Pacific equatorial age transect. IODP Sci. Prosp., 320/321. doi:10.2204/ iodp.sp.320321.2008

Pälike, H., Norris, R.D., Herrle, J.O., Wilson, P.A., Coxall, H.K., Lear, C.H., Shackleton, N.J., Tripati, A.K., and Wade, B.S., 2006. The heartbeat of the Oligocene climate system. Science, 314(5807):1894-1898. doi:10.1126/science.1133822

Pälike, H., Frazier, J., and Zachos, J.C., 2006. Extended orbitally forced palaeoclimatic records from the equatorial Atlantic Ceara Rise. Quat. Sci. Rev., 25(23-24):31383149. doi:10.1016/j.quascirev.2006.02.011

Petronotis, K.E., 1991. Paleomagnetic studies of the skewness of Pacific plate marine magnetic anomalies 2532R: implications for anomalous skewness and the motion of the Pacific plate and hotspots [Ph.D. thesis]. Northwestern Univ., Evanston, IL.

Petronotis, K.E., Gordon, R.G., and Acton, G.D., 1994. A 57 Ma Pacific plate paleomagnetic pole determined from a skewness analysis of crossings of marine magnetic anomaly 25r. Geophys. J. Int., 118(3):529-554. doi:10.1111/j.1365-246X.1994.tb03983.x

Pribnow, D.F.C., Kinoshita, M., and Stein, C.A., 2000. Thermal Data Collection and Heat Flow Recalculations for ODP Legs 101-180: Hanover, Germany (Inst. Joint Geosci. Res., Inst. Geowiss. Gemeinschaftsauf. [GGA]). http:// www-odp.tamu.edu/publications/heatflow/ ODPReprt.pdf

Raffi, I., Backman, J., Fornaciari, E., Pälike, H., Rio, D., Lourens, L., and Hilgen, F., 2006. A review of calcareous nannofossil astrobiochronology encompassing the past 25 million years. Quat. Sci. Rev., 25(23-24):3113-3137. doi:10.1016/j.quascirev.2006.07.007

Sager, W.W., and Pringle, M.S., 1988. Mid-Cretaceous to early Tertiary apparent polar wander path of the Pacific plate. J. Geophys. Res., [Solid Earth], 93(B10):1175311771. doi:10.1029/JB093iB10p11753

Shackleton, N.J., Hall, M.A., Raffi, I., Tauxe, L., and Zachos, J., 2000. Astronomical calibration age for the Oligocene-Miocene boundary. Geology, 28(5):447-450. doi:10.1130/00917613(2000)28<447:ACAFTO>2.0.CO;2

van Morkhoven, F.P.C.M., Berggren, W.A., and Edwards, A.S., 1986. Cenozoic Cosmopolitan Deep-Water Benthic Foraminifera. Bull. Cent. Rech. Explor.-Prod. Elf-Aquitaine, Mem. 11.

Young, J.R., 1999. Neogene. In Bown, P.R. (Ed.), Calcareous Nannofossil Biostratigraphy: Dordrecht, The Netherlands (Kluwer Academic Publ.), 225-265.

Zachos, J., Pagani, M., Sloan, L., Thomas, E., and Billups, K., 2001. Trends, rhythms, and aberrations in global climate $65 \mathrm{Ma}$ to present. Science, 292(5517):686-693. doi:10.1126/science.1059412

Zachos, J.C., Flower, B.P., and Paul, H., 1997. Orbitally paced climate oscillations across the Oligocene/Miocene boundary. Nature (London, U. K.), 388(6642):567570. doi:10.1038/41528

Zachos, J.C., Shackleton, N.J., Revenaugh, J.S., Pälike, H., and Flower, B.P., 2001. Climate response to orbital forcing across the Oligocene-Miocene boundary. Science, 292(5515):274-278. doi:10.1126/science.1058288

Publication: 30 October 2010 MS 320321-107 
Figure F1. A. ETOPO1 (Amante and Eakins, 2008) bathymetric overview map of Site U1335 and PEAT drilling locations, with previous ODP and DSDP sites. B. Swath map bathymetry for Site U1335 region from the AMAT03 site survey. Black labels $=$ seismic shotpoints, white labels $=$ bathymetric contours. White line $=$ survey Line 8 (Fig. F2). F.Z. = fracture zone.
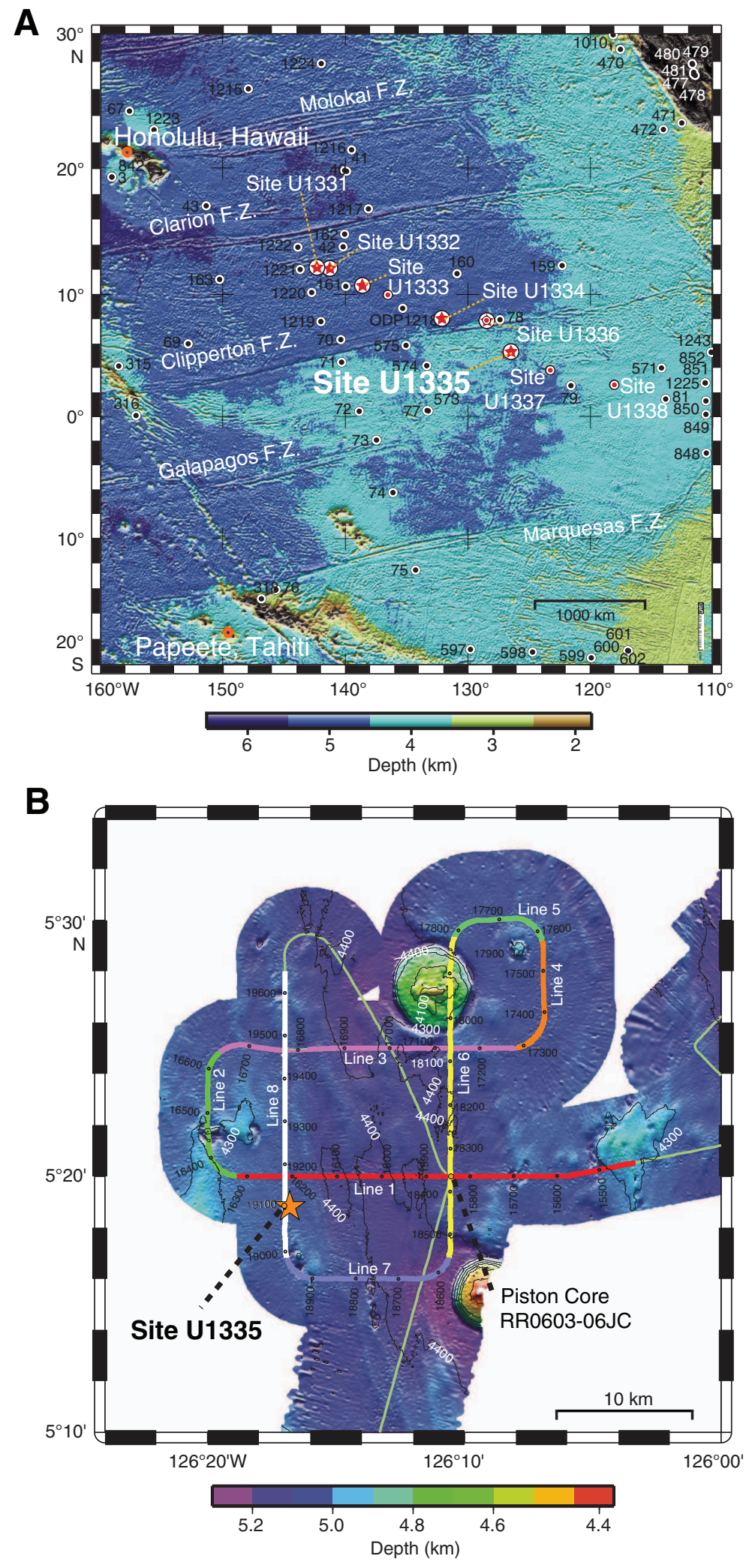
Figure F2. Seismic reflection profile PEAT-6C (Site U1335) Line 8 from the 48-channel seismic reflection survey, annotated in shotpoints (Lyle et al., 2006). Data are filtered, stacked, and migrated. Tentative conversion from two-way traveltime to depth uses velocity model of Busch et al. (2006). SP = shotpoint. mbsl = meters below sea level. TD $=$ total depth.

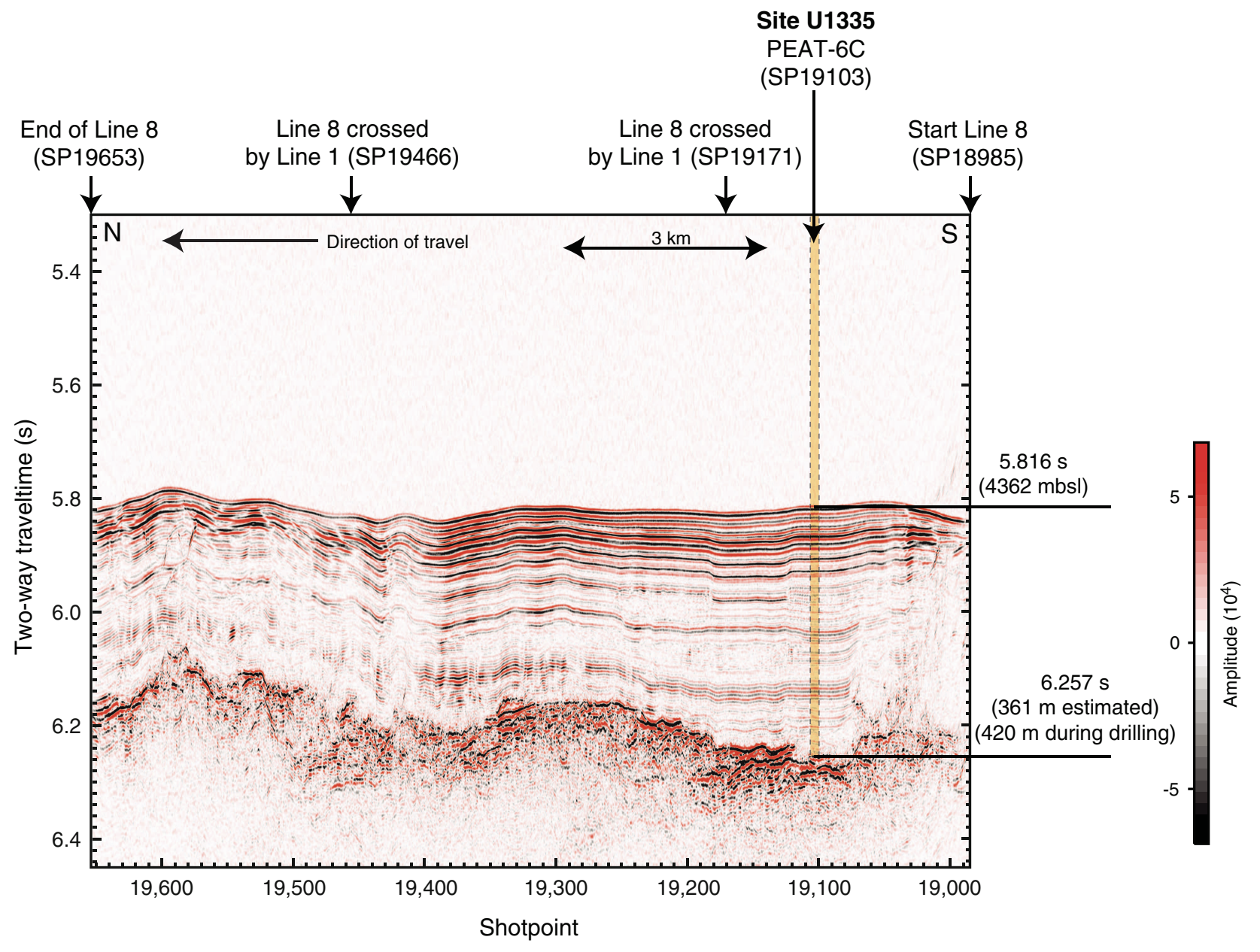


Figure F3. Site U1335 summary. At Site U1335, planktonic foraminifer Zone O6 is informally divided into an upper and lower part using the base of Paragloborotalia pseudokugleri.

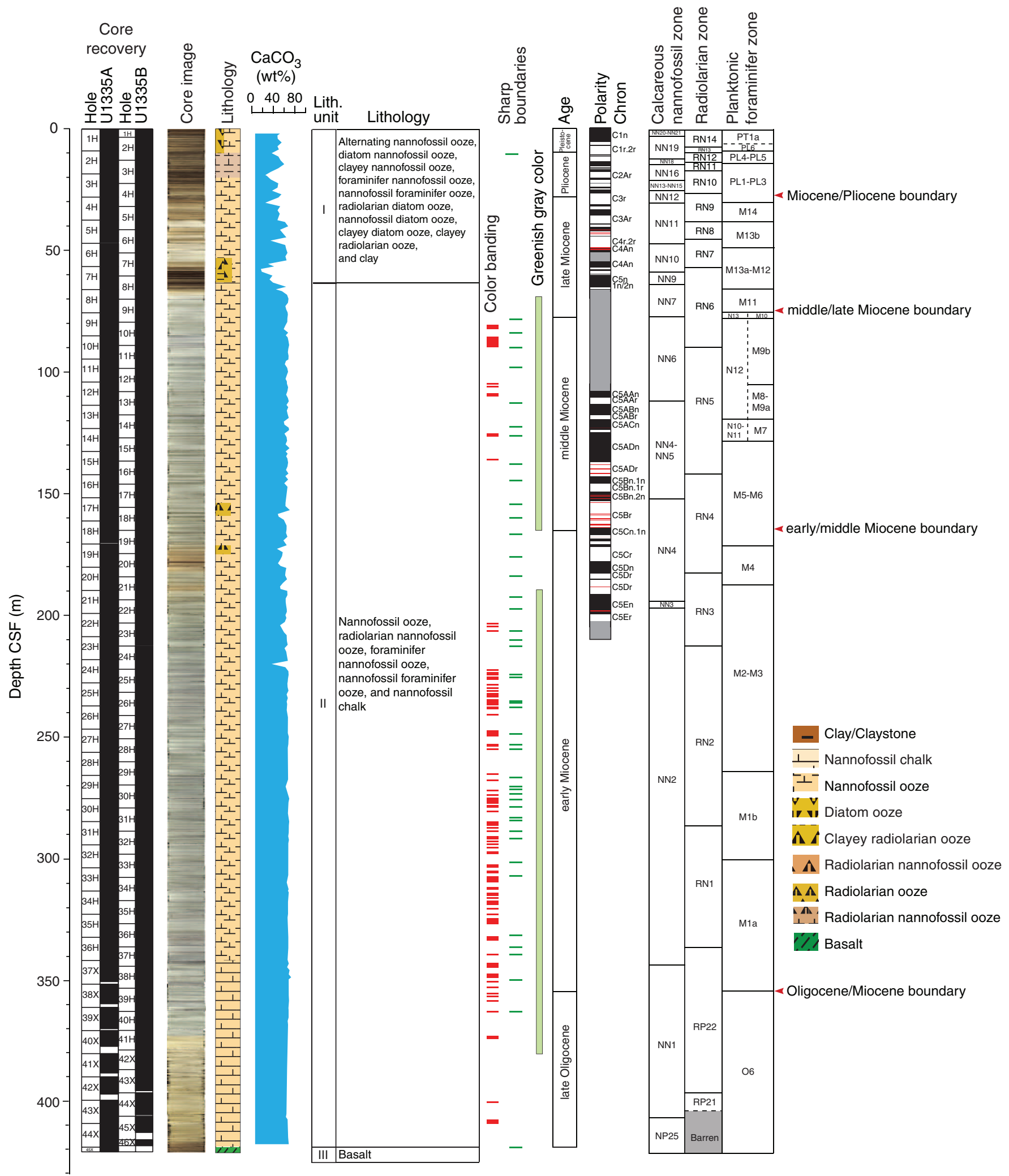


Figure F4. Lithologic summary, Site U1335. Magnetic stratigraphy data based on Hole U1335B. Geomagnetic polarity: red interval $=$ possible geomagnetic excursions $($ cryptochron), gray interval $=$ undetermined interval. $\mathrm{L}^{*}, \mathrm{~b}^{*}=$ reflectance value of sediment as defined in the LAB color model.

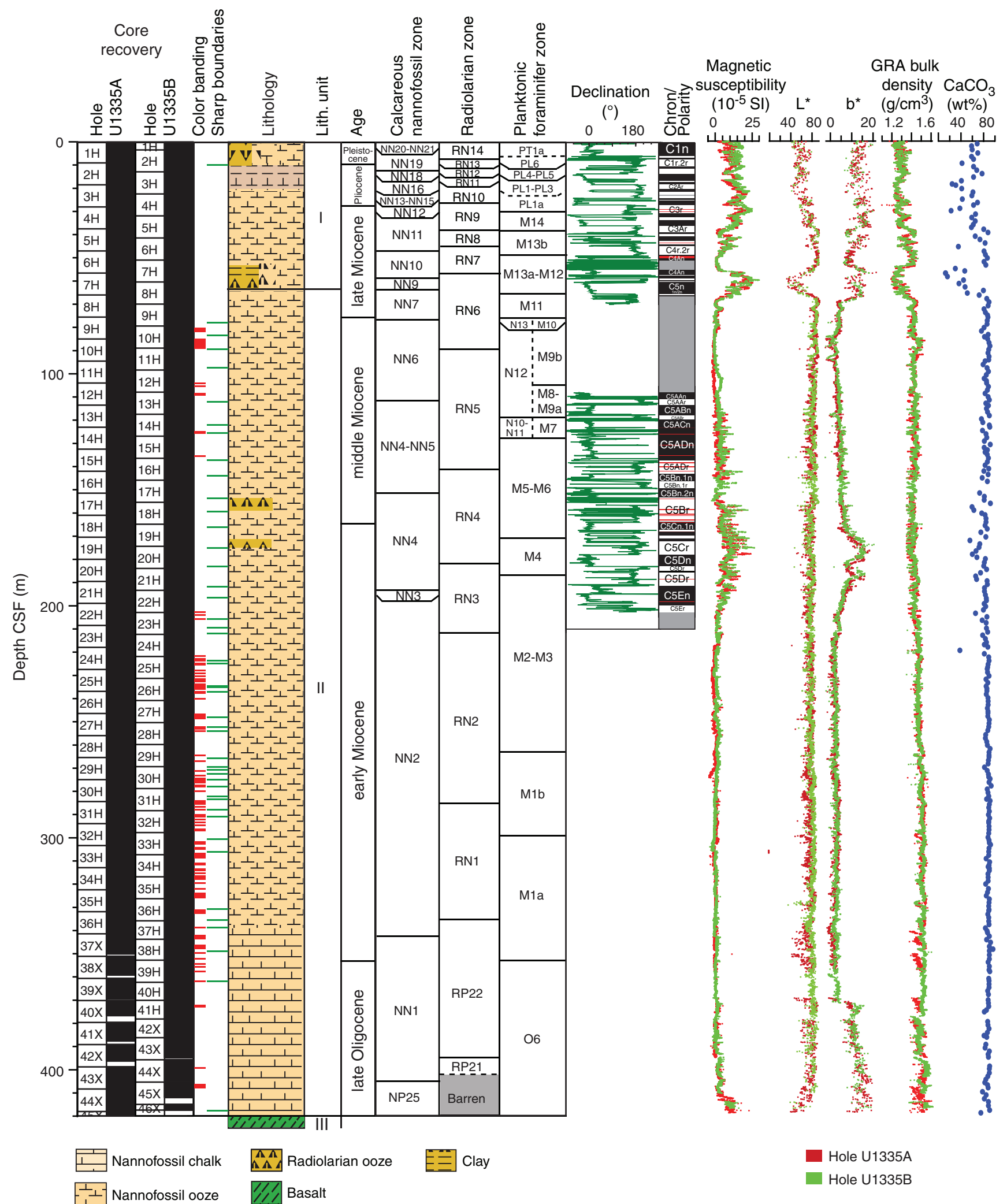


Figure F5. Calcium carbonate $\left(\mathrm{CaCO}_{3}\right)$, total carbon (TC), inorganic carbon (IC), and total organic carbon (TOC) determined by normal and acidification methods in sediments from Hole U1335A. (See "Lithostratigraphy" for information on unit boundaries.)
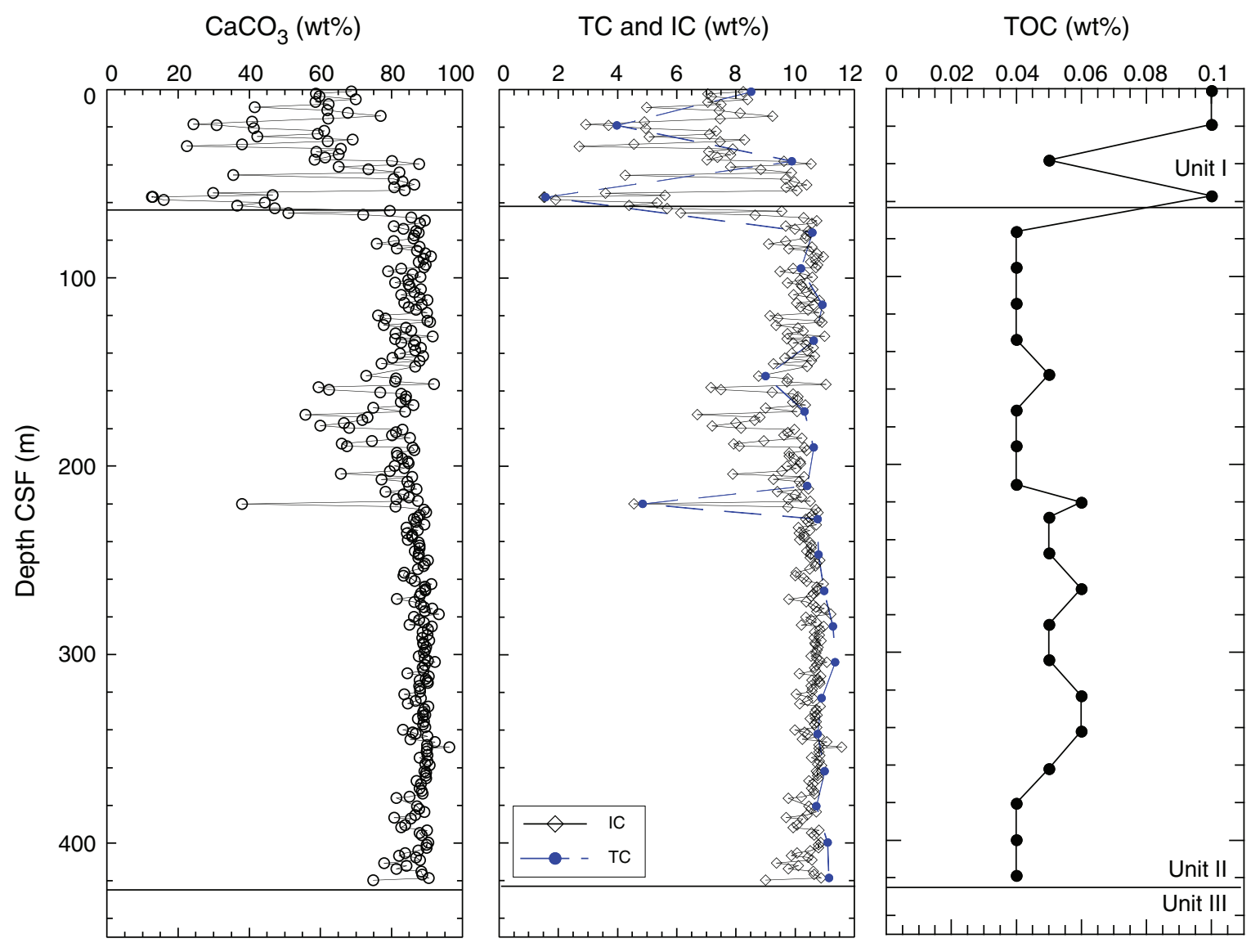
Figure F6. Color reflectance and magnetic susceptibility, Hole U1335A. Line scan images from Cores 320U1335A-7H through $8 \mathrm{H}, 18 \mathrm{H}$ through $22 \mathrm{H}$, and $39 \mathrm{X}$ through $45 \mathrm{X}$ highlight observed color changes. $\mathrm{L}^{*}, \mathrm{a}^{*}, \mathrm{~b}^{*}$ $=$ reflectance value of sediment as defined in the LAB color model.

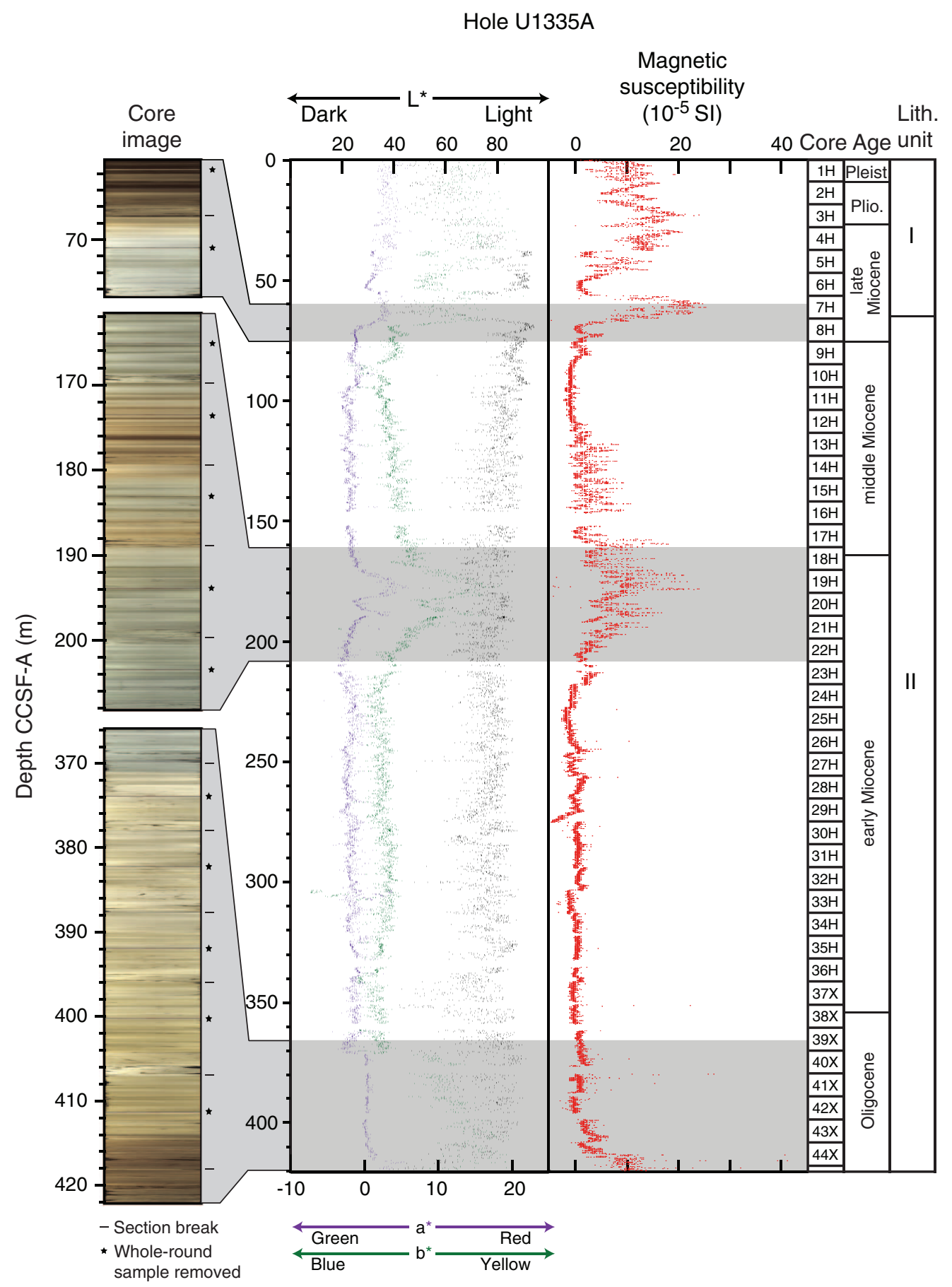


Figure F7. Summary of magnetic susceptibility and paleomagnetic results, Hole U1335B. Declinations are shown in sample coordinates (not reoriented to geographical coordinates).

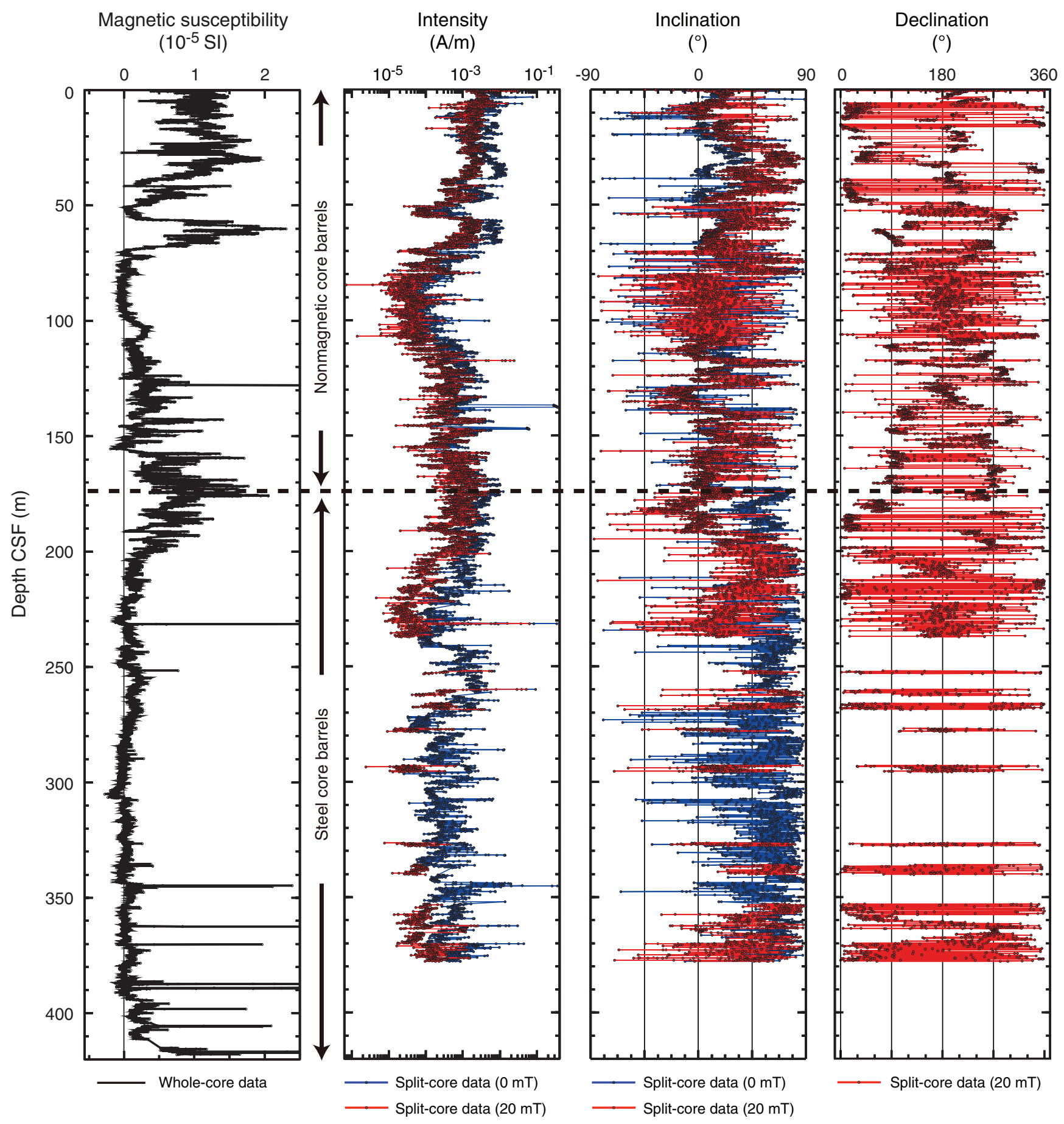


Figure F8. Line scan images of nannofossil ooze interbedded with nannofossil diatom ooze. A. Interval 320U1335B-10H-3, 54-90 cm. B. Interval 320-U1335B-24H-6, 34-70 cm. Note that the beds of nannofossil diatom ooze are characterized by rough surfaces (both sections were scraped in the same way with a glass slide in preparation for line image scanning).

A
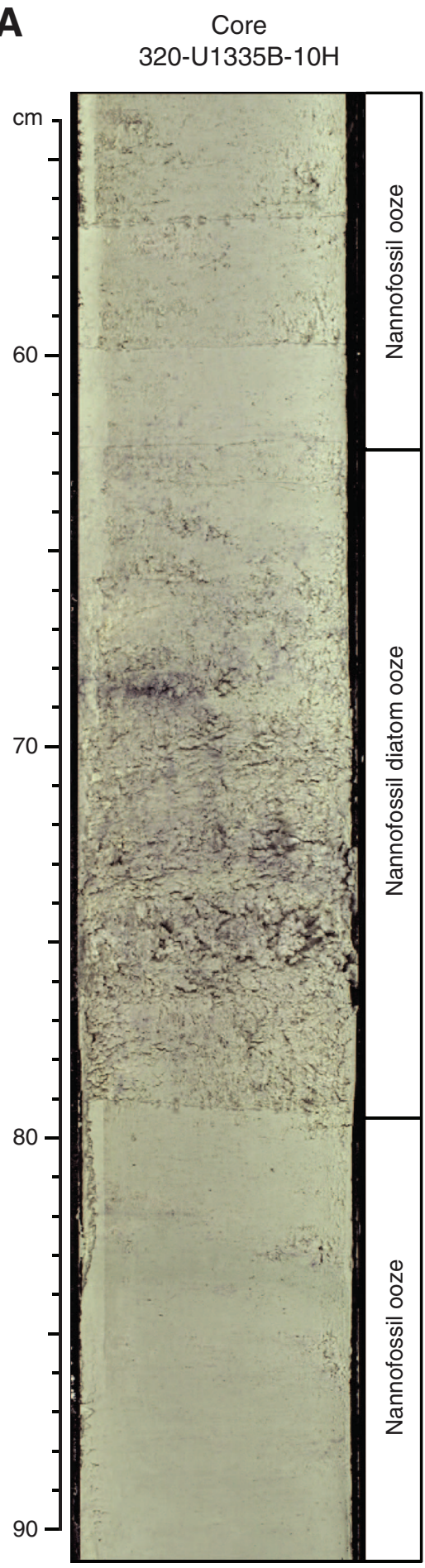

B
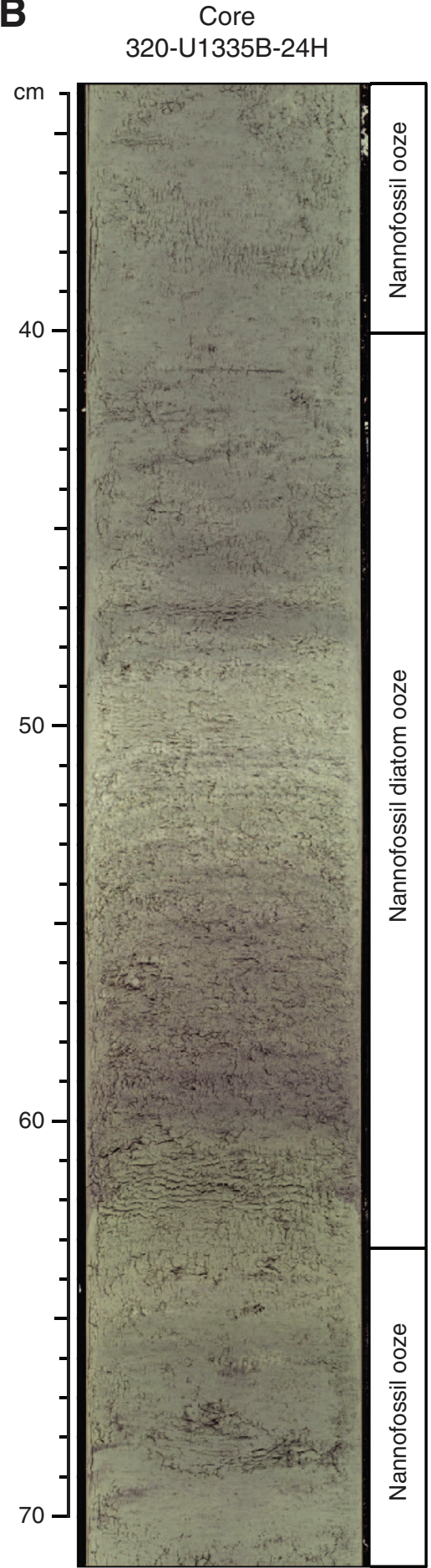
Figure F9. Photomicrographs of smear slides, Site U1335. Left image = plane-polarized light, right image = cross-polarized light. A. Nannofossil ooze (Sample 320-U1335B-10H-1, $110 \mathrm{~cm}$ ). B. Nannofossil diatom ooze (Sample 320-U1335B-10H-3, $70 \mathrm{~cm}$ ). See "Site U1335 smear slides" in "Core descriptions" for full descriptions.
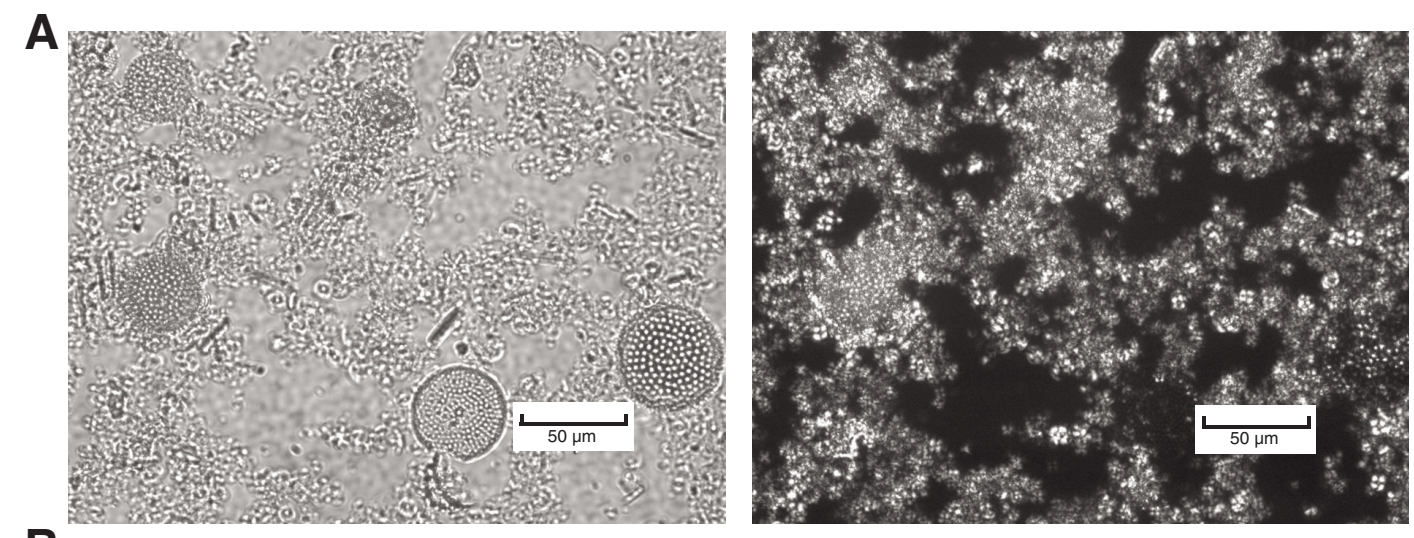

B
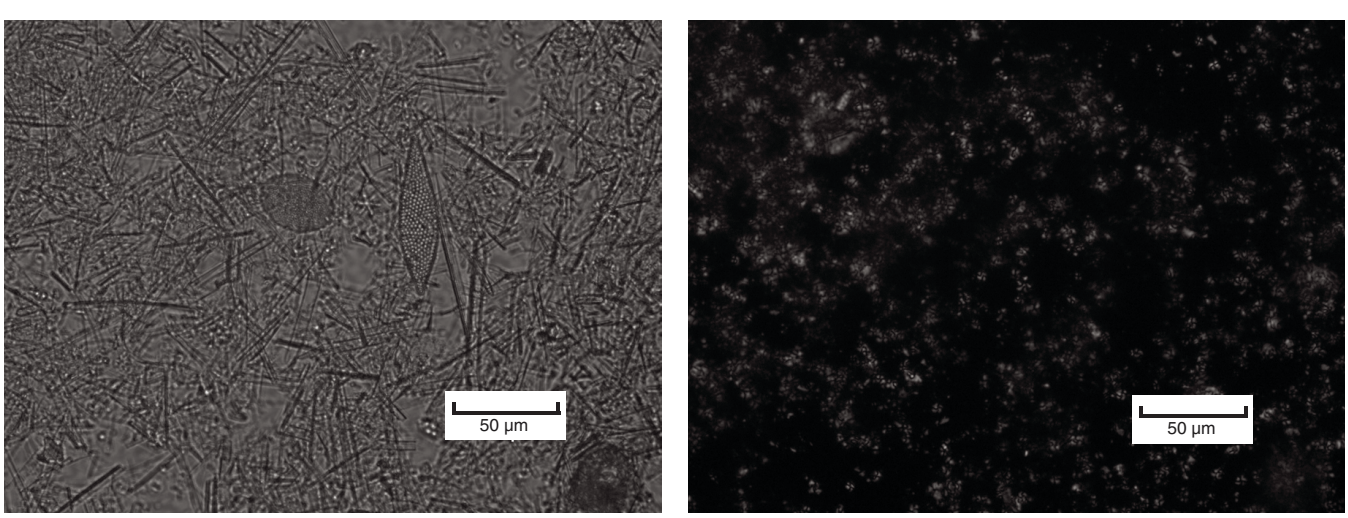
Figure F10. A. Line scan image of interval 320-U1335A-12H-6, 62-144 cm, including a nannofossil foraminifer ooze bed. B, C. Photomicrographs of angular basalt fragments (Sample 320-U1335A-12H-6, $134 \mathrm{~cm}$ ). Basalt fragment containing glass groundmass and lath-shaped minerals inside. D. Close-up line scan image around the base of nannofossil foraminifer ooze.

\section{A Section 320-U1335A-12H-6}

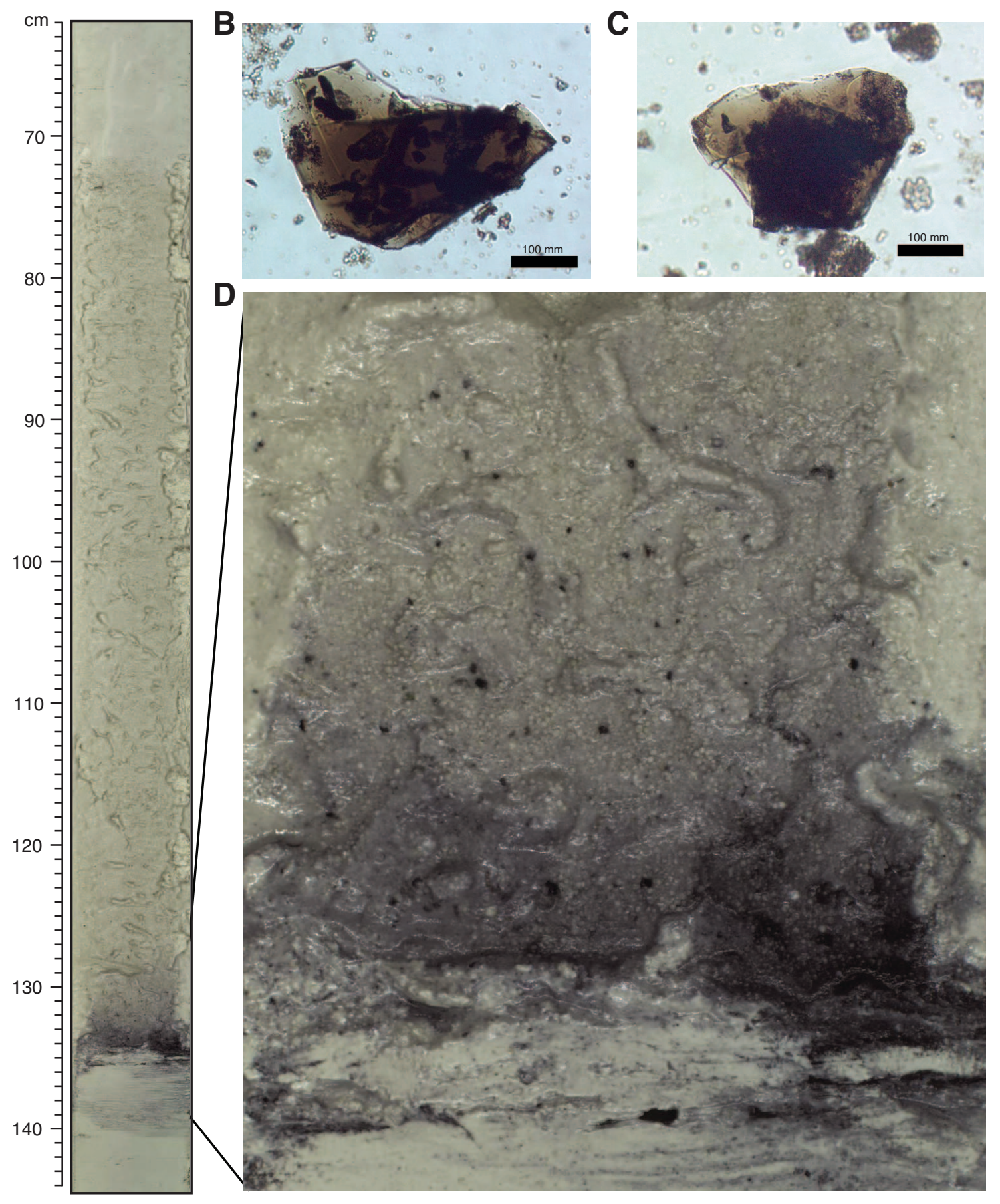


Figure F11. Line scan image of color bands in partially consolidated interval (interval 320-U1335A-39X-1, 102$115 \mathrm{~cm})$.

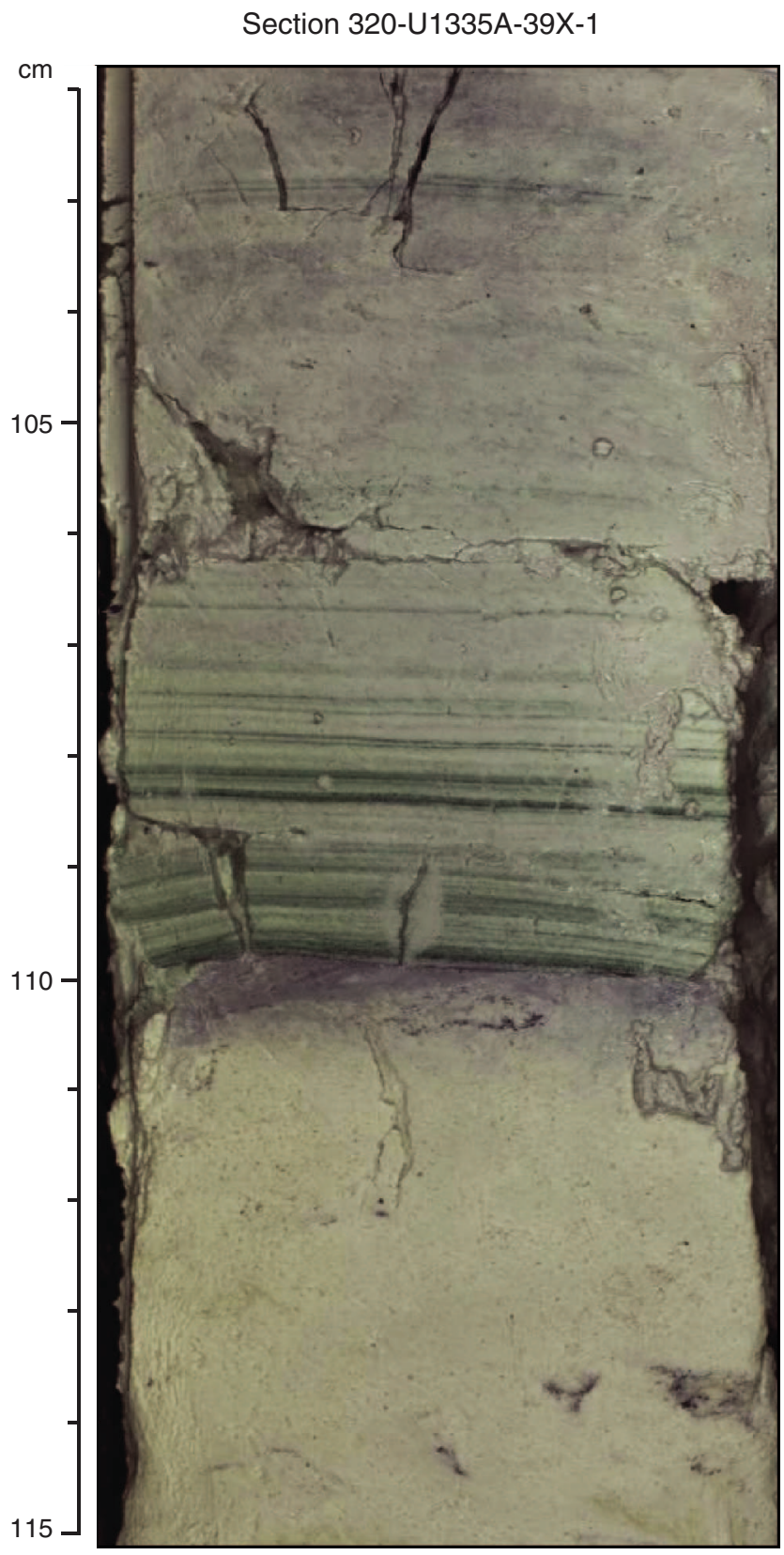


Figure F12. Line scan images of sharp boundary and overlying nannofossil foraminifer ooze. A. Boundary at $28 \mathrm{~cm}$ in interval 320-U1335A-2H-1, 116-133 cm. B. Boundary at $54 \mathrm{~cm}$ in interval 320-U1335B-2H-6, 41-59 $\mathrm{cm}$.

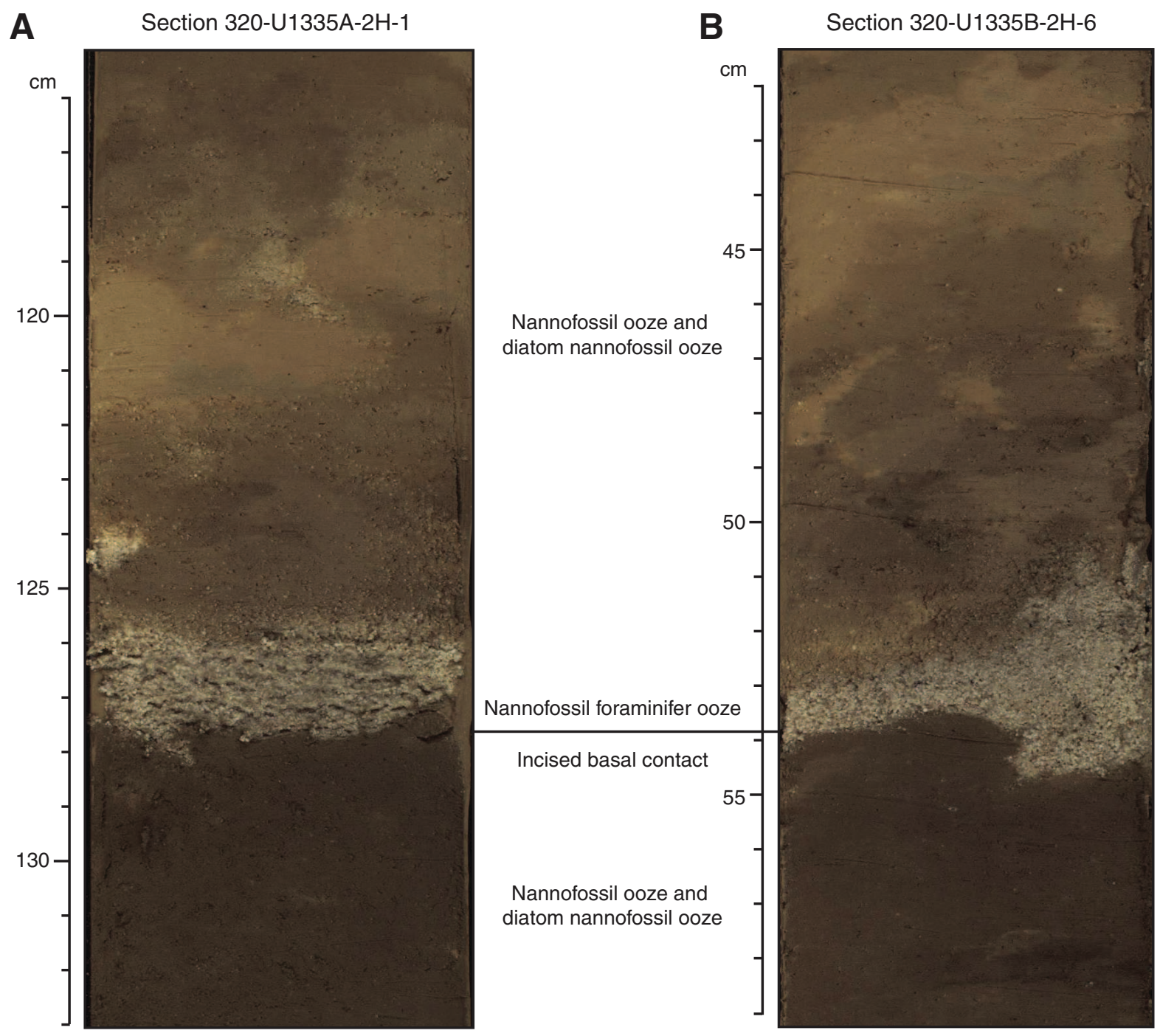


Figure F13. Integrated calcareous and siliceous microfossil biozonation, Site U1335.

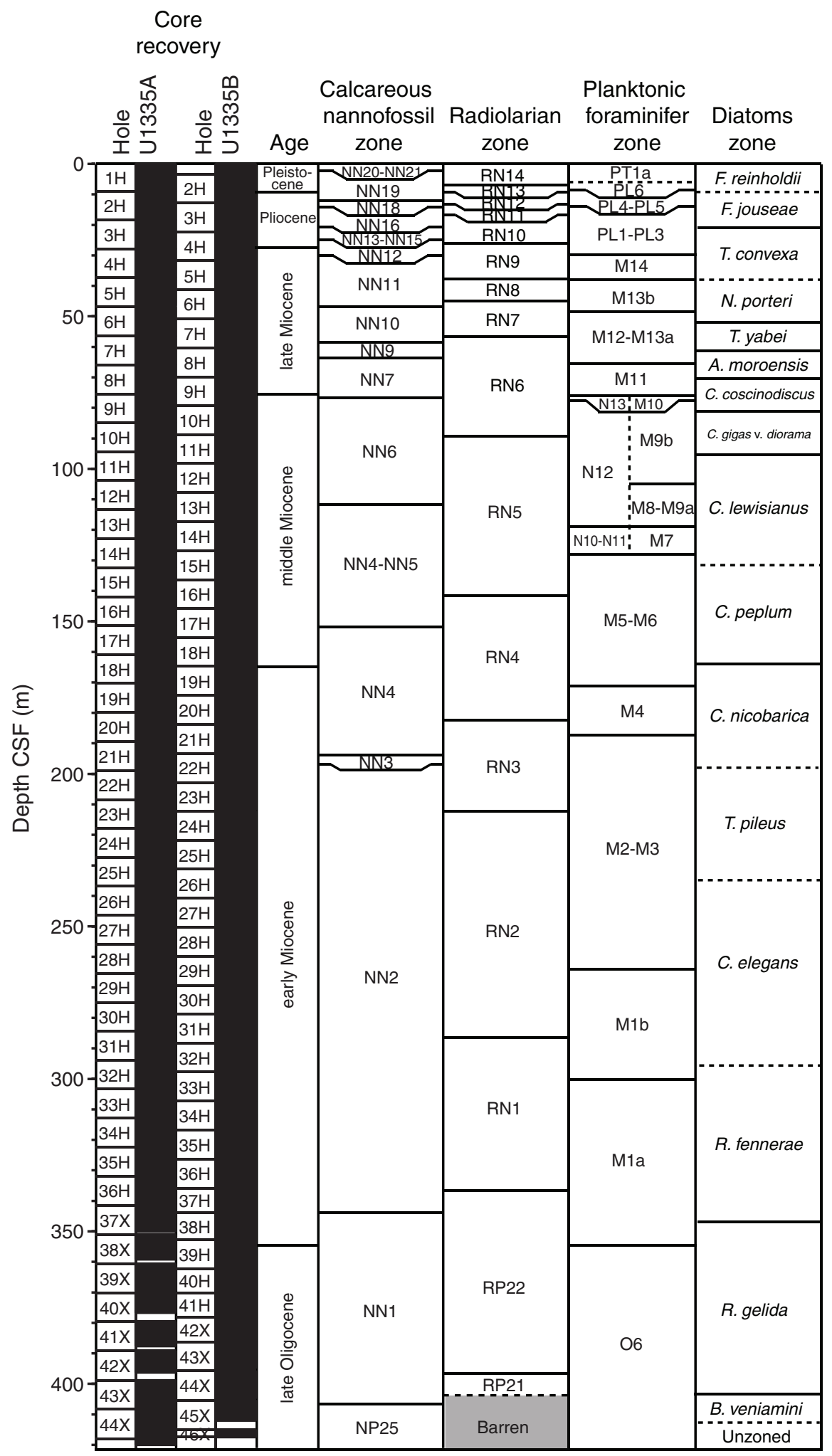


Figure F14. Linear sedimentation rates and chronostratigraphic markers, Site U1335.

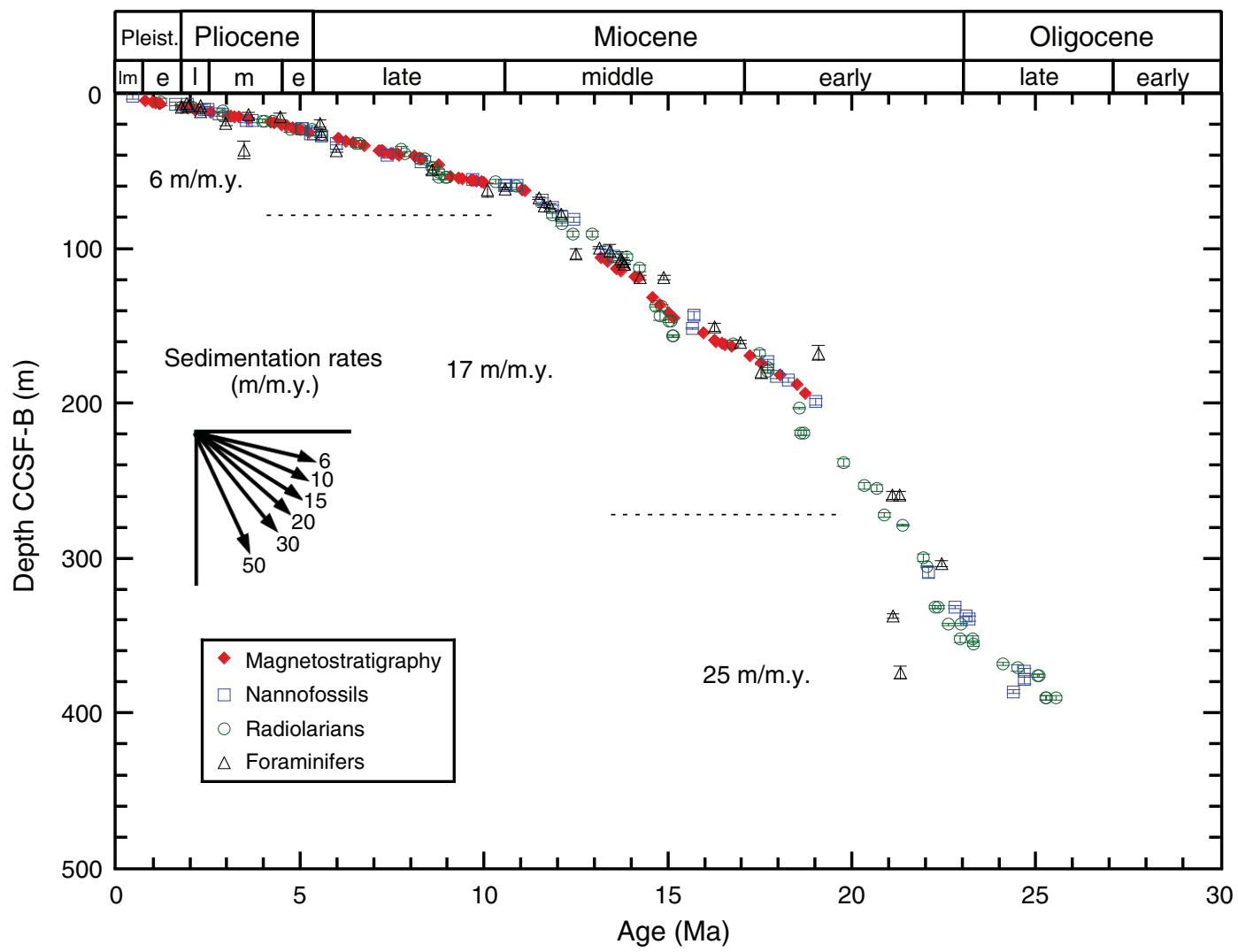


Figure F15. Summary of magnetic susceptibility and paleomagnetic results, Hole U1335A. Declinations are shown in sample coordinates (not reoriented to geographical coordinates). $\mathrm{PCA}=$ principle component analysis.

Hole U1335A

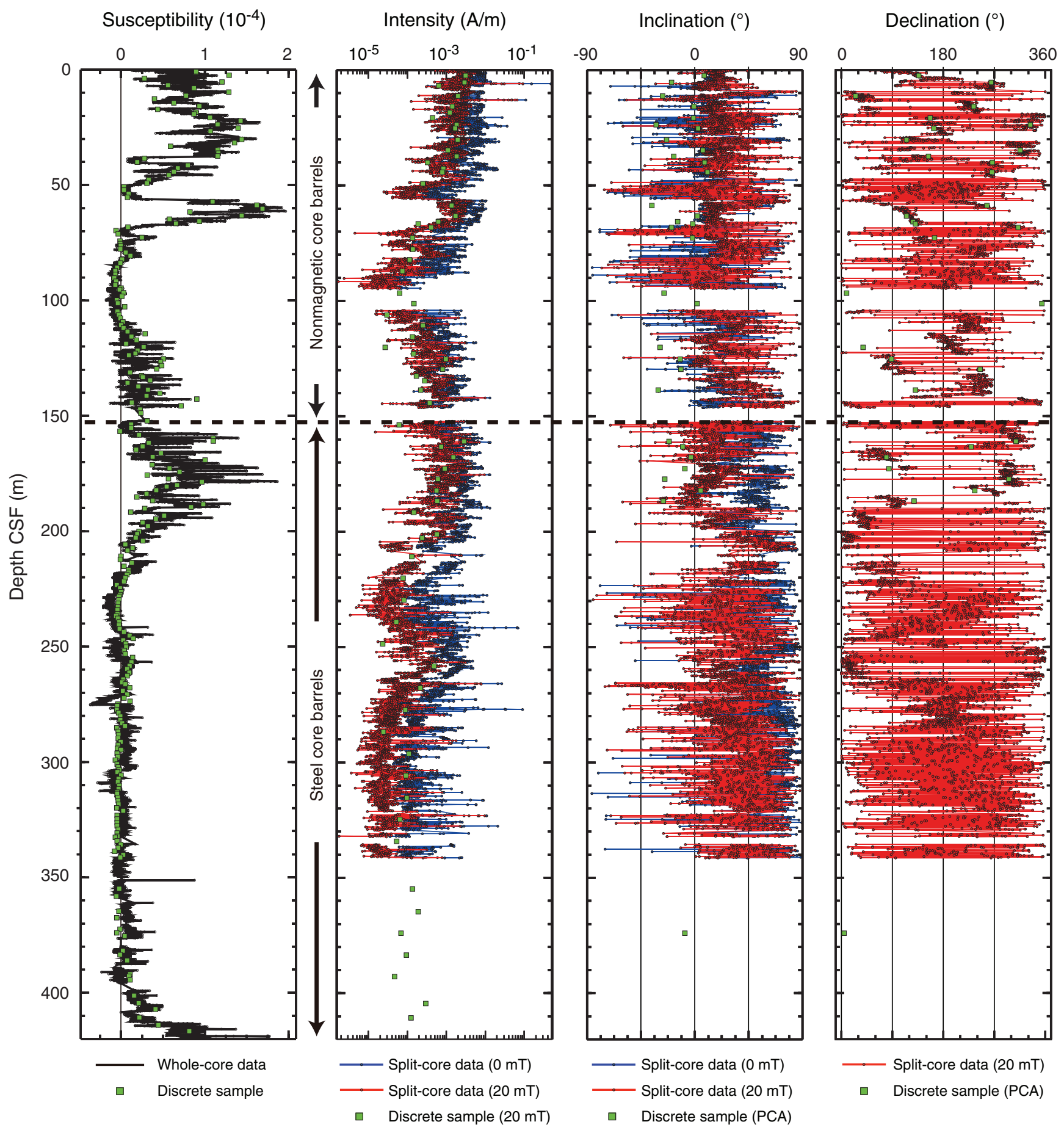


Figure F16. Representative alternating-field demagnetization (demag) results for Site U1335 samples. Left plot $=$ vector endpoints of paleomagnetic directions on vector demagnetization diagrams or Zijderveld plots (solid circles $=$ horizontal projections, open circles $=$ vertical projections, gray circles $=$ data not used in computing ChRM, black dashed line $=$ ChRM direction), middle plot $=$ intensity variation with progressive demagnetization, right plot $=$ directions plotted on an equal-angle stereonet. Vector demagnetization diagrams of A and B show relatively well resolved characteristic remanent magnetizations, whereas that of $\mathrm{C}$ does not. A. Normal polarity sample (320-U1335A-1H-2, $90 \mathrm{~cm})(2.40 \mathrm{~m} \mathrm{CSF})$ B. Reversed polarity sample (320-U1335A-17H-7, 50 $\mathrm{cm})(160.90 \mathrm{~m} \mathrm{CSF})$. C. Weakly magnetized sample from the magnetic-low zone (Sample 320-U1335A-10H-2, $85 \mathrm{~cm})(87.25 \mathrm{~m} \mathrm{CSF}) . \mathrm{NRM}=$ natural remanent magnetization. Inc = inclination, $\mathrm{Dec}=$ declination, $\mathrm{MAD}=$ maximum angular deviation.

A Sample 320-U1335A-1H-2, $90 \mathrm{~cm}$

Depth: $2.40 \mathrm{~m}$ CSF

$\mathrm{NRM}=6.94 \times 10^{-3} \mathrm{~A} / \mathrm{m}$
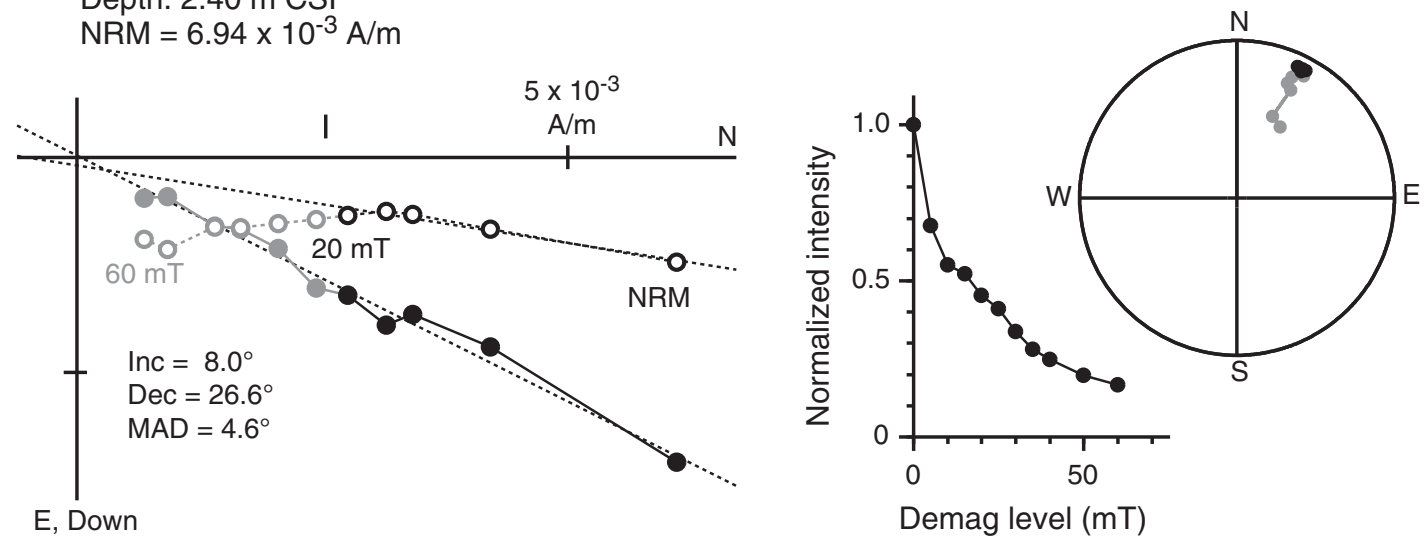

B

E, Down

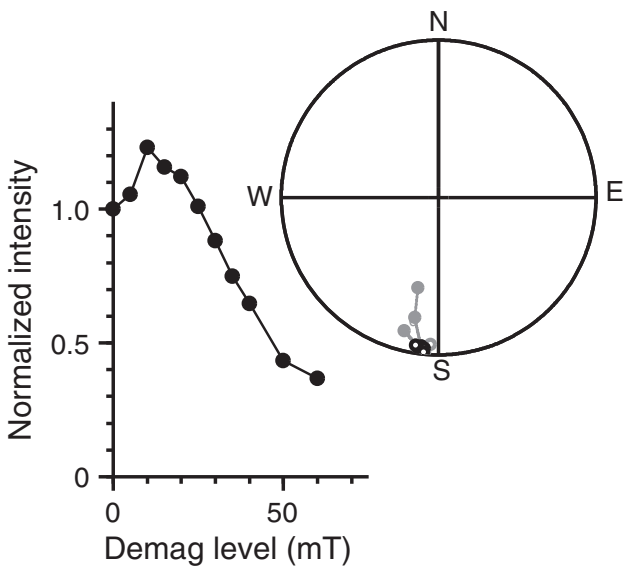

C

Sample 320-U1335A-10H-2, 85 cm

Depth: $87.25 \mathrm{~m}$ CSF

$\mathrm{NRM}=9.04 \times 10^{-5} \mathrm{~A} / \mathrm{m}$
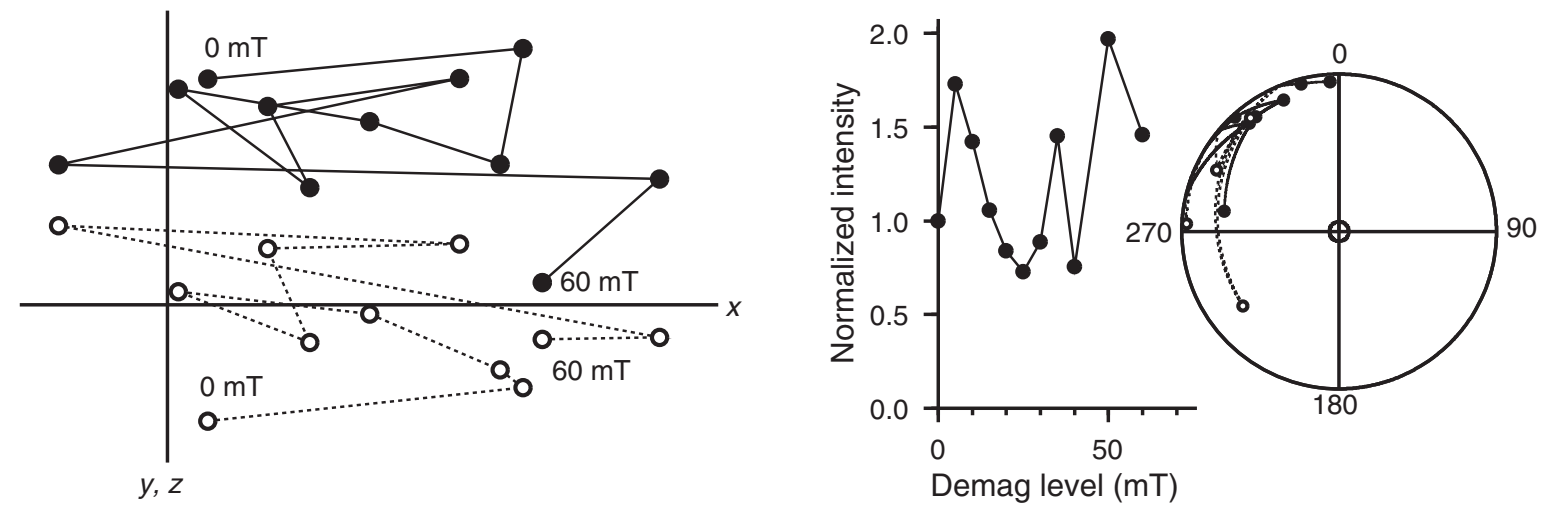
Figure F17. Latitude of the virtual geomagnetic pole (VGP), Hole U1335A. North latitudes = normal polarity (black), south latitudes = reversed polarity (white). Red bars = intervals of possible geomagnetic excursions. Gray bars = indeterminate polarity, such as in the magnetic-low zone. A. 0-70 m CSF. (Continued on next page.)

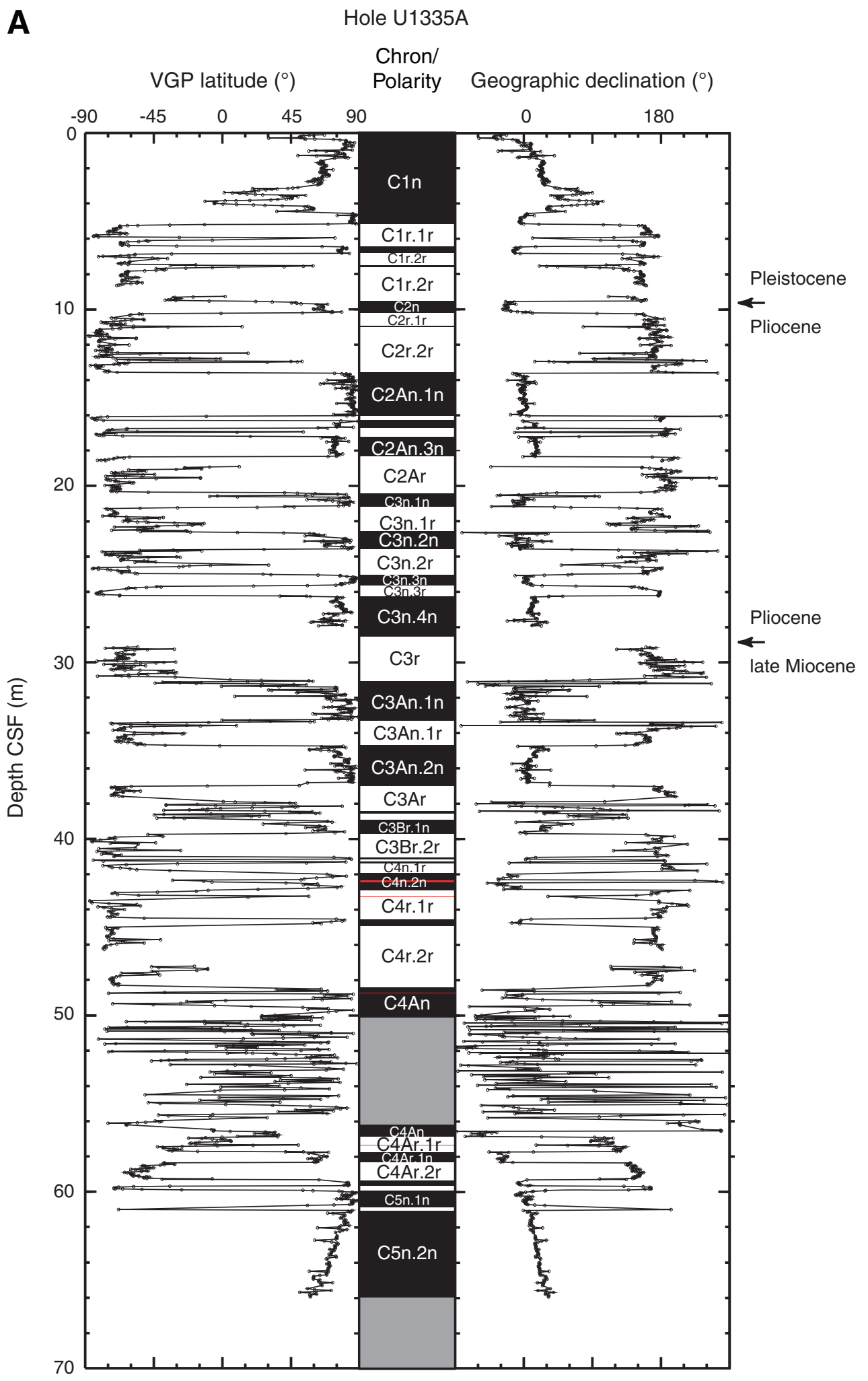


Figure F17 (continued). B. 150-210 m CSF.

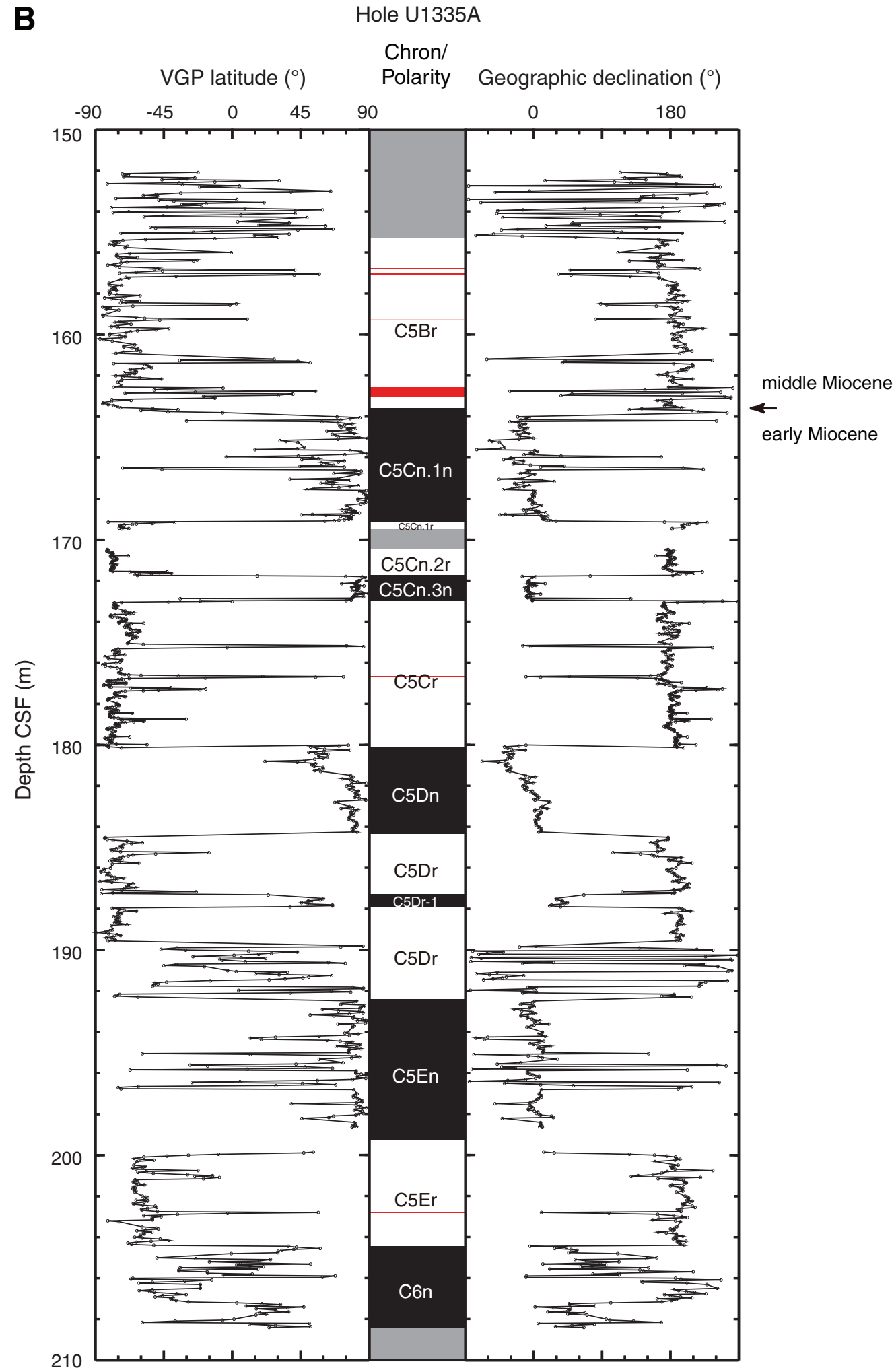


Figure F18. Latitude of the virtual geomagnetic pole (VGP), Hole U1335B. North latitudes = normal polarity (black), south latitudes = reversed polarity (white). Red bars = intervals of possible geomagnetic excursions. Gray bars = indeterminate polarity, such as in the magnetic-low zone. A. 0-70 m CSF. (Continued on next page.)

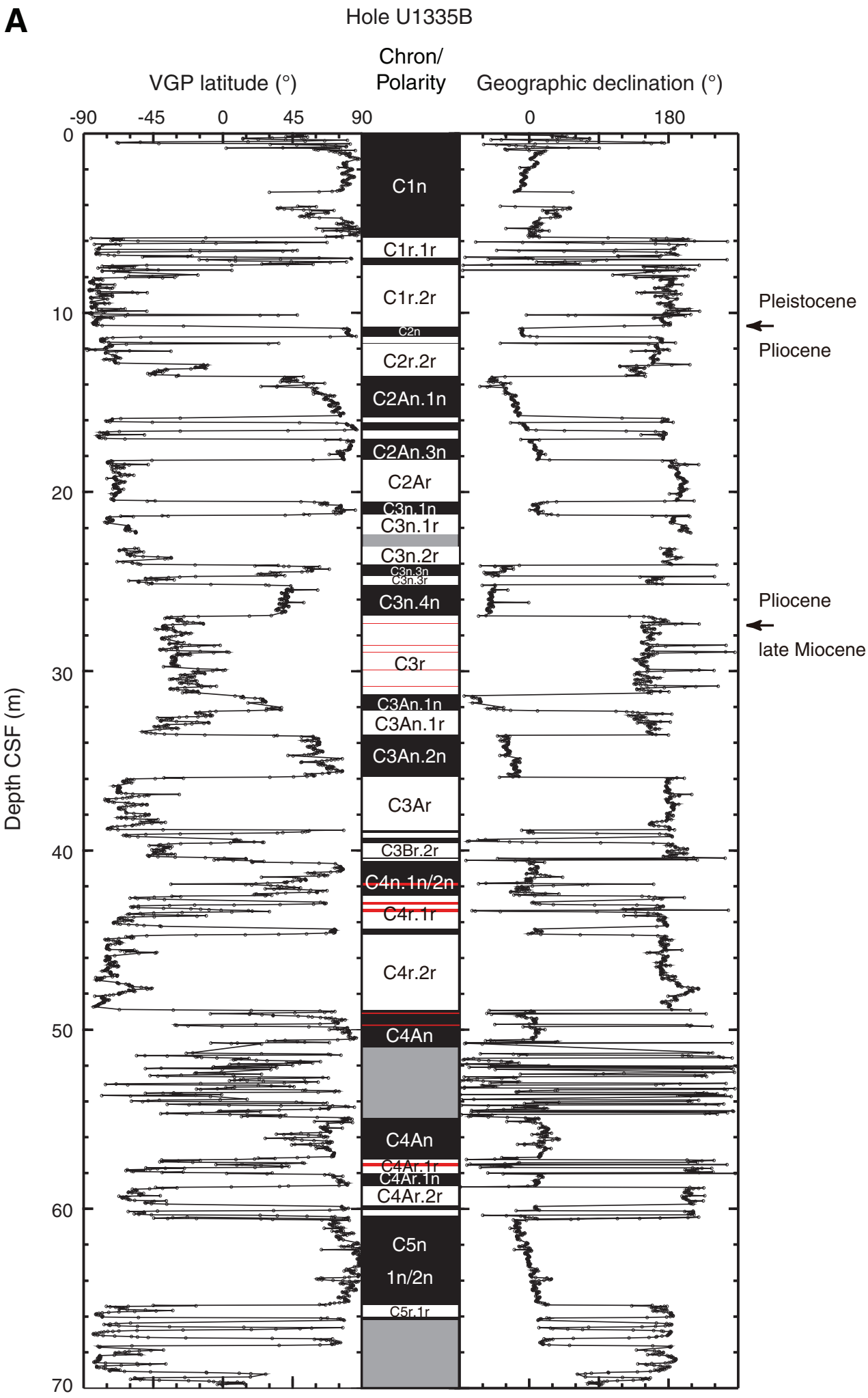


Figure F18 (continued). B. 105-205 m CSF.

B

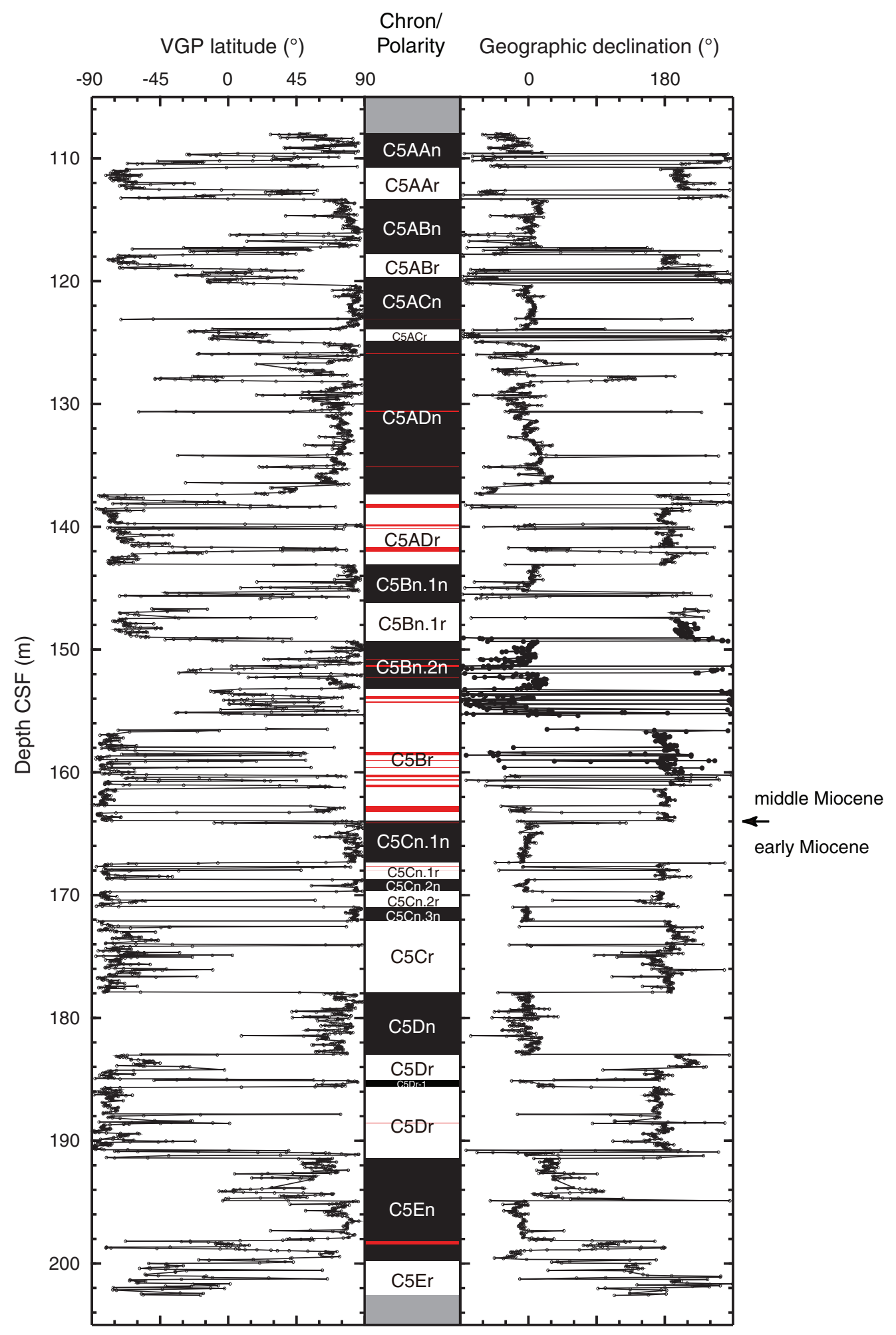


Figure F19. Interstitial water chemistry, Holes U1335A and U1335B. Values below the detection limit (see Table T21) are plotted as zero. (See "Lithostratigraphy" for information on unit boundaries.)
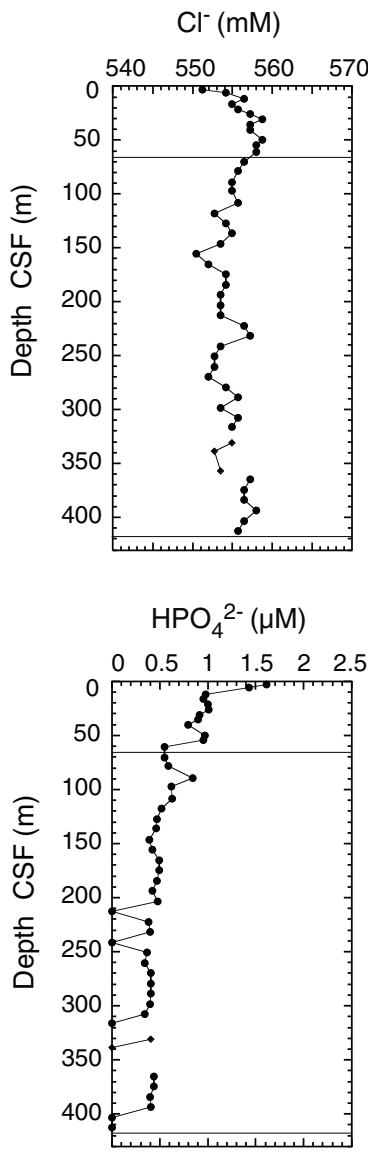

$\mathrm{Mg}^{2+}(\mathrm{mM})$

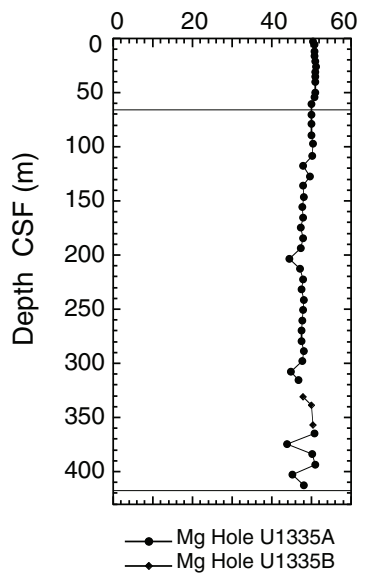

Alkalinity (mM)

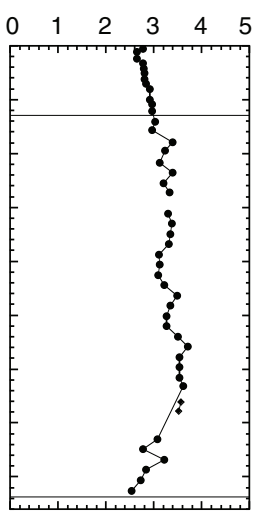

Silicate $(\mu \mathrm{M})$

$\mathrm{SO}_{4}^{2}(\mathrm{mM})$

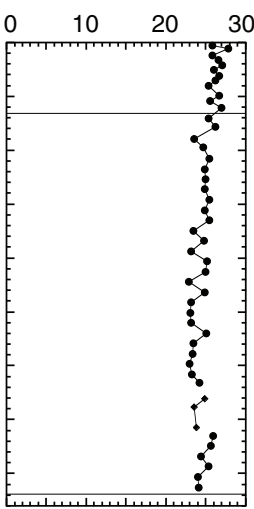

$\mathrm{Ba}^{2+}(\mu \mathrm{M})$

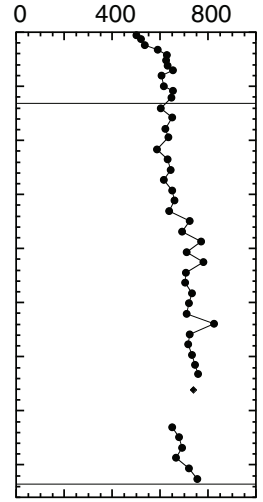

$\mathrm{Sr}^{2+}(\mu \mathrm{M})$
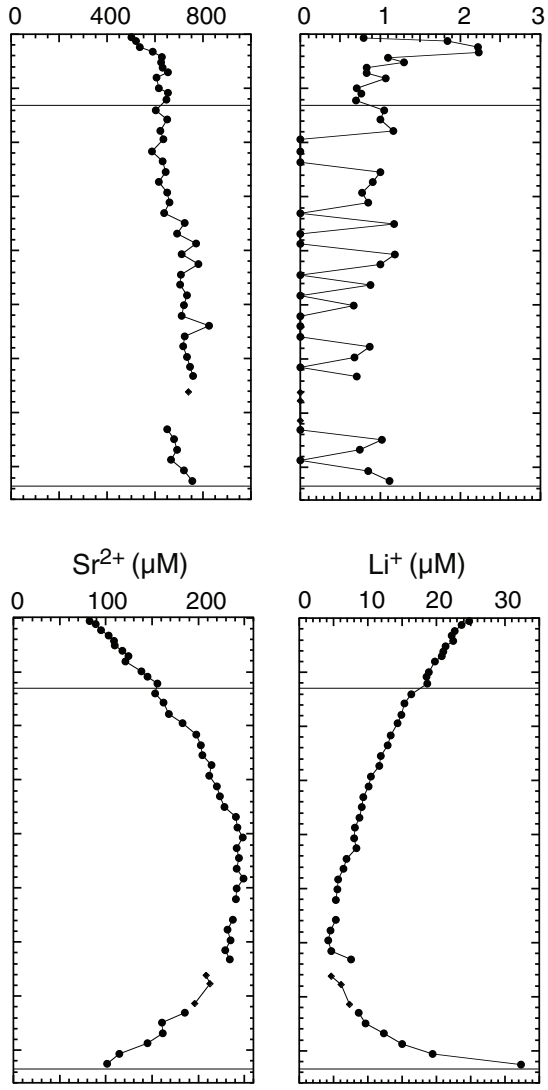

$\mathrm{Li}^{+}(\mu \mathrm{M})$

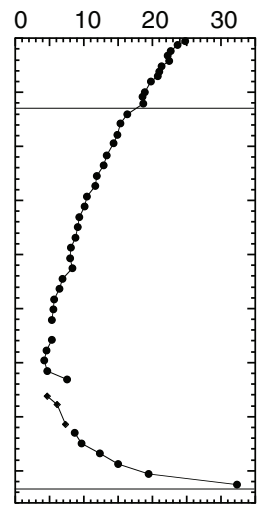

$\mathrm{Fe}^{2+}(\mu \mathrm{M})$

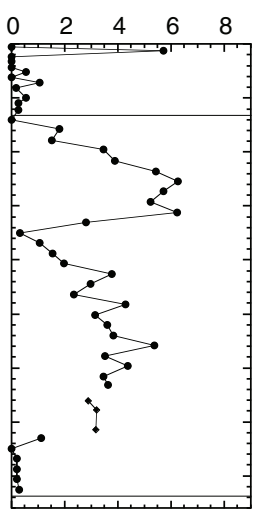

B $(\mu \mathrm{M})$

$\mathrm{Mn}^{2+}(\mu \mathrm{M})$

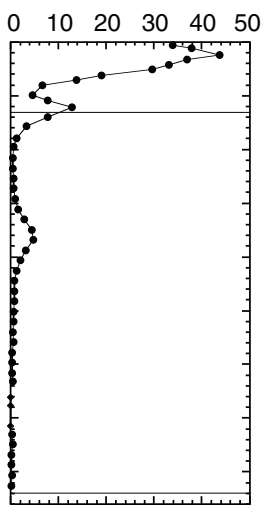

$$
\mathrm{Ca}^{2+}(\mathrm{mM})
$$
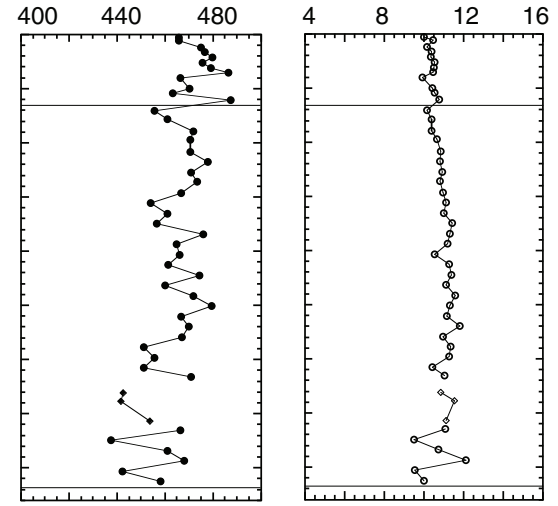

$\mathrm{K}^{+}(\mathrm{mM})$

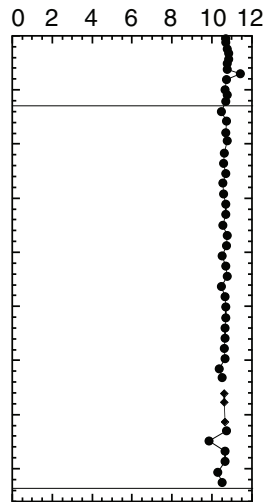


Figure F20. Whole-Round Multisensor Logger (WRMSL) and natural gamma radiation (NGR) data, Holes U1335A and U1335B. Data for Hole U1335B are plotted using offsets $\left(0.5 \mathrm{~g} / \mathrm{cm}^{3}\right.$ for bulk density; $10 \times 10^{-5}$ SI for magnetic susceptibility; $100 \mathrm{~m} / \mathrm{s}$ for $P$-wave velocity; 10 cps for NGR).

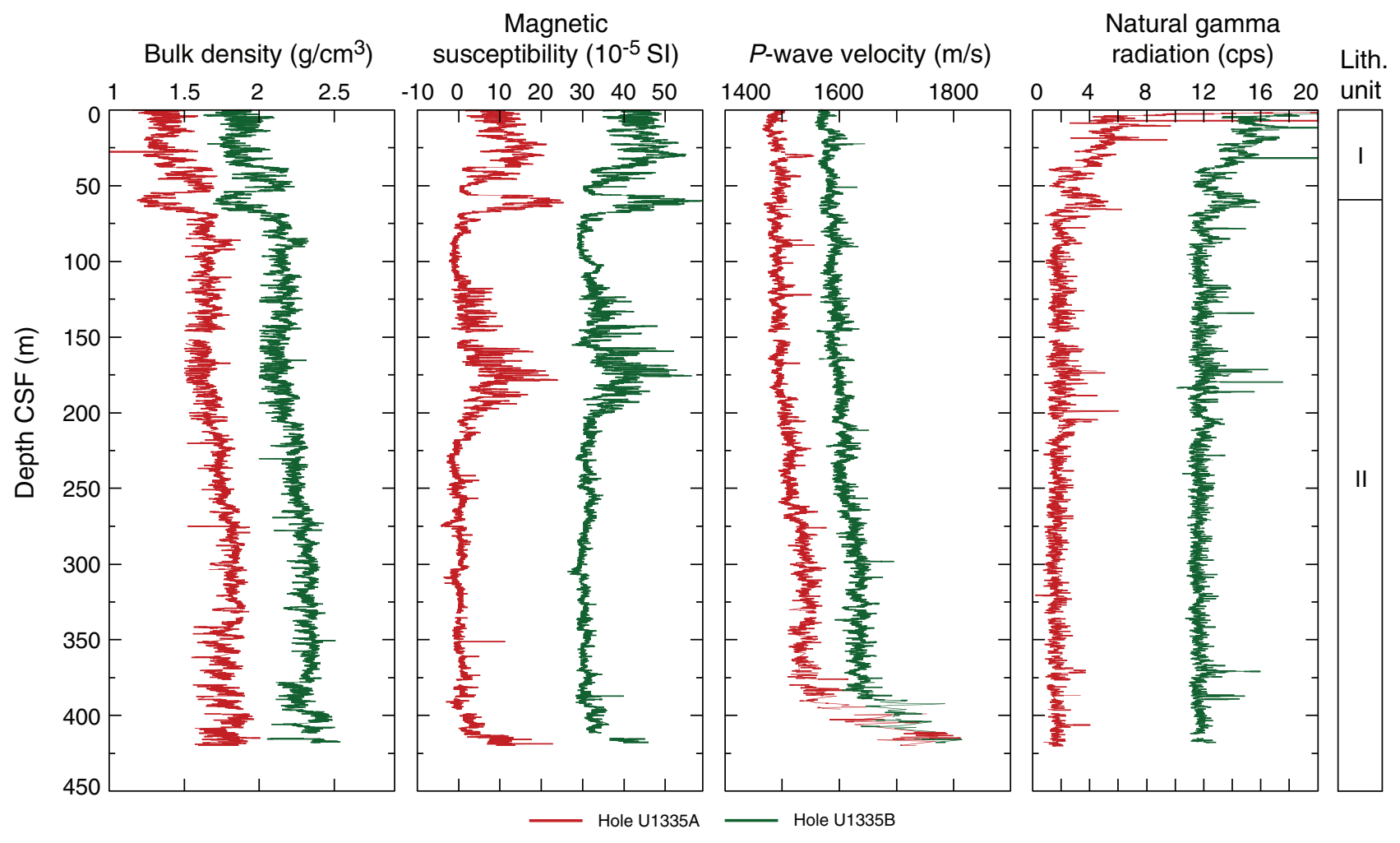


Figure F21. Moisture and density (MAD) measurements, Hole U1335A. A. Porosity and water content. B. MAD and gamma ray attenuation (GRA) bulk density. C. Grain density.

A

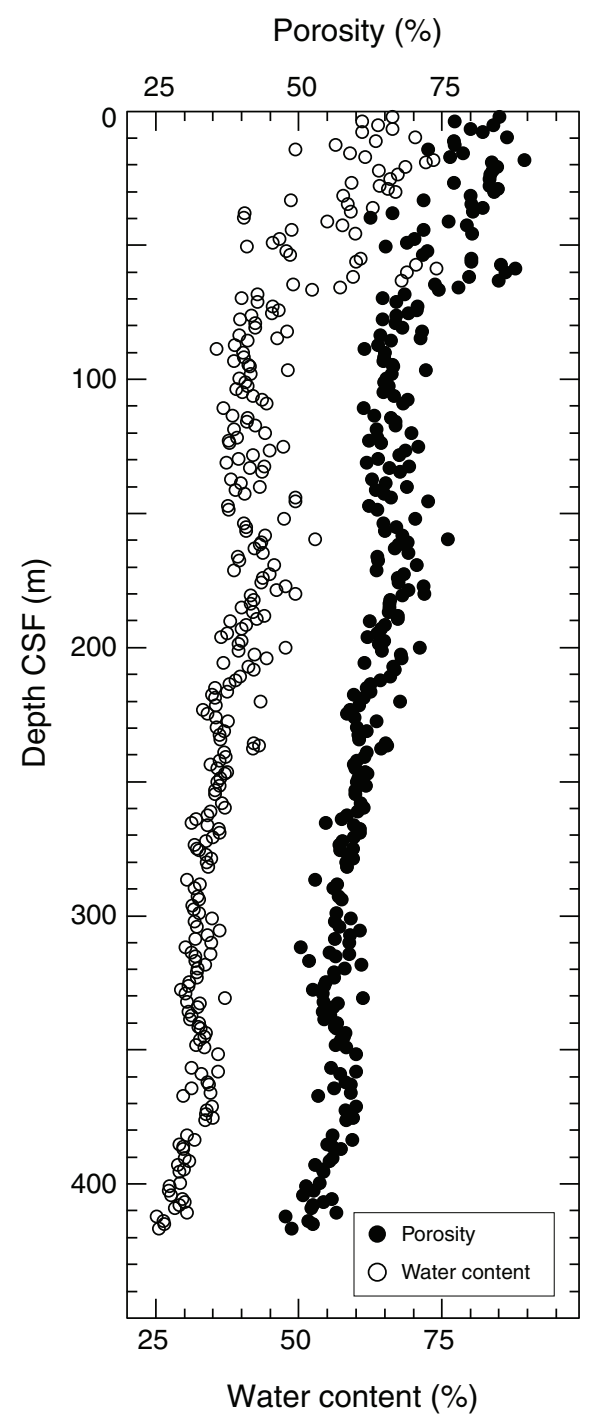

B Bulk density $\left(\mathrm{g} / \mathrm{cm}^{3}\right)$

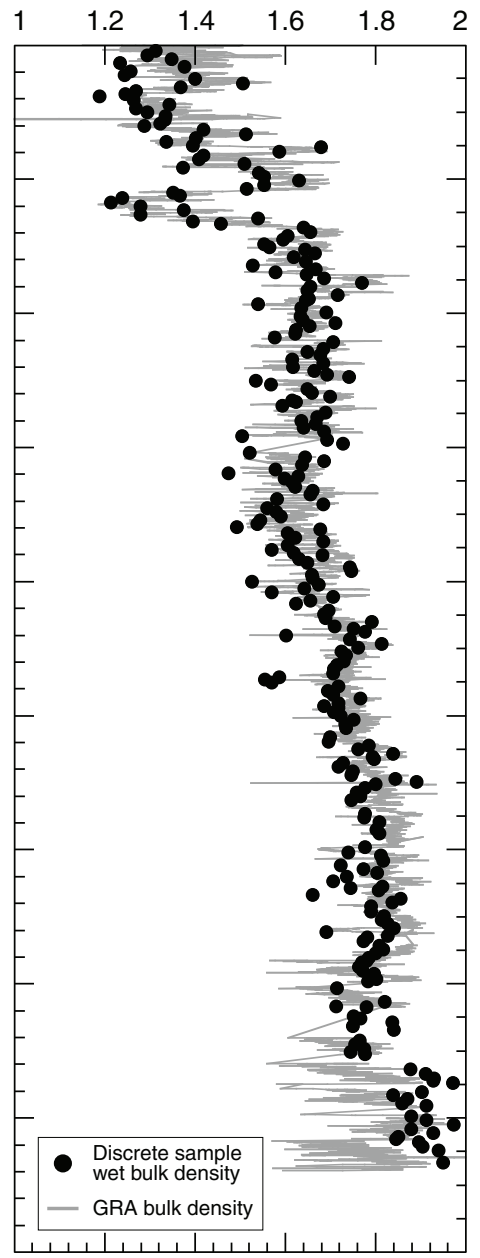

C Grain density $\left(\mathrm{g} / \mathrm{cm}^{3}\right)$

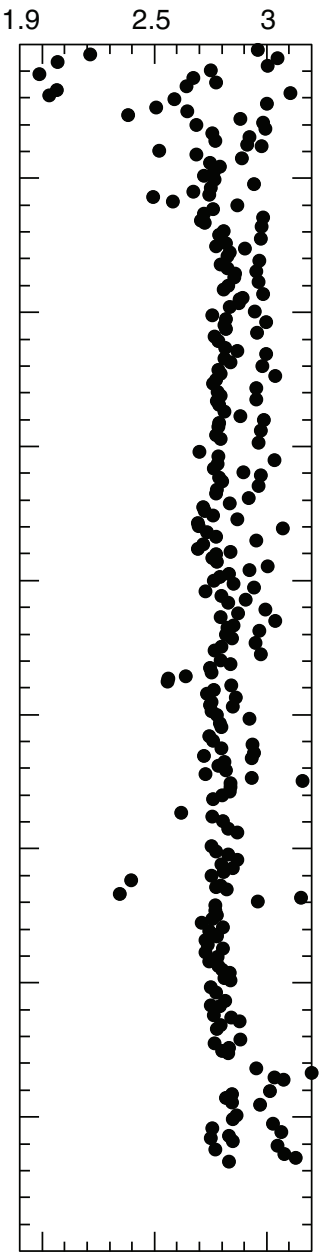

Lith.

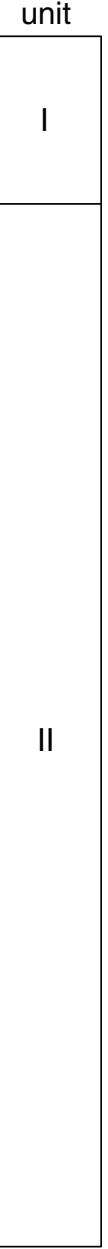


Figure F22. Moisture and density (MAD) analysis of discrete samples, Hole U1335A. Gamma ray attenuation (GRA) density interpolated with a $20 \mathrm{~cm}$ wide Gaussian window.
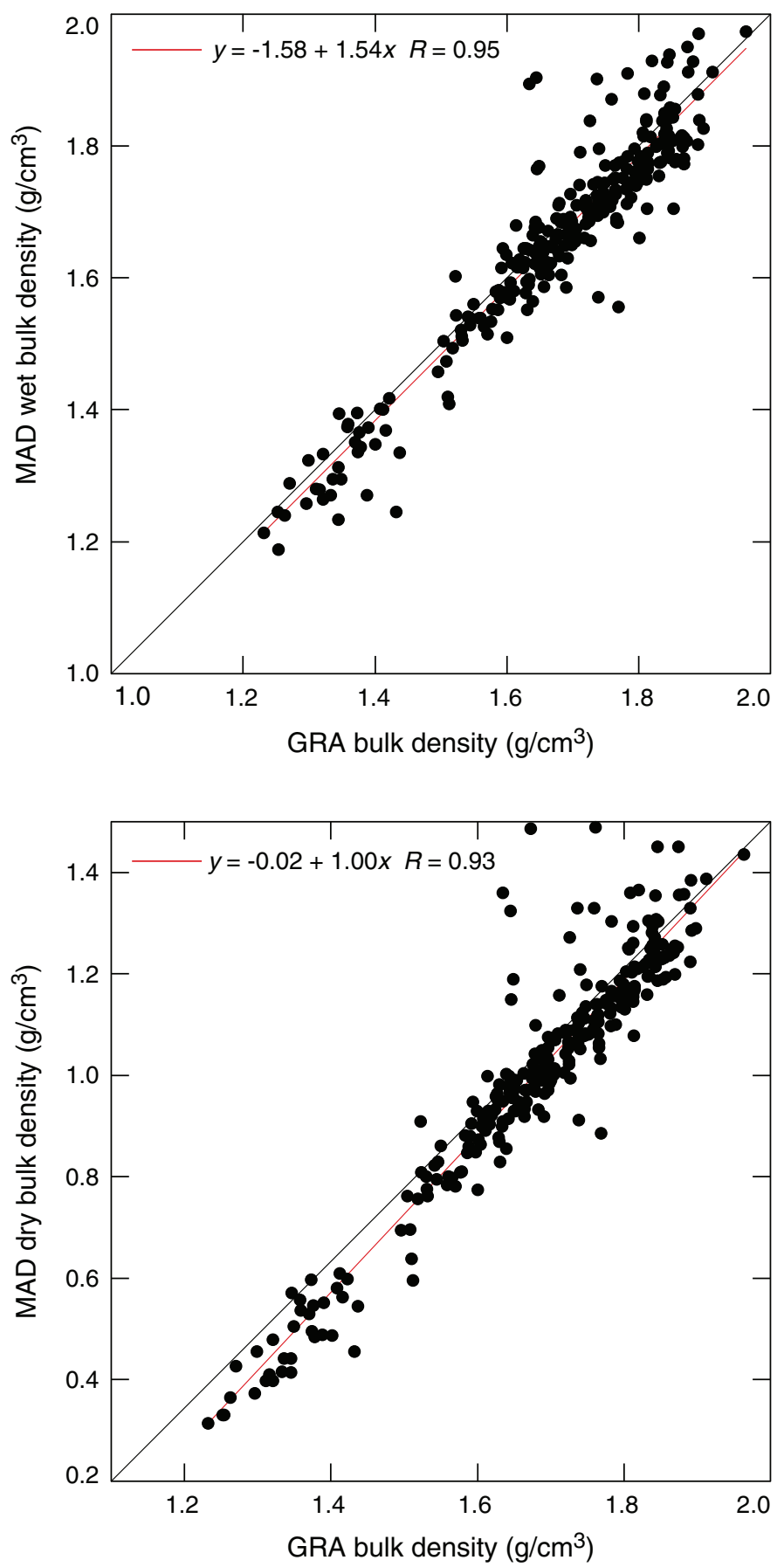
Figure F23. Compressional wave velocity from the $P$-wave logger (PWL) and discrete velocity measurements on split core from Hole U1335A, using the contact probe for $x$-axis measurements and insertion probes for $y$ and $z$-axis measurements (see "Compressional wave velocity" for a note on postcruise velocity correction.)
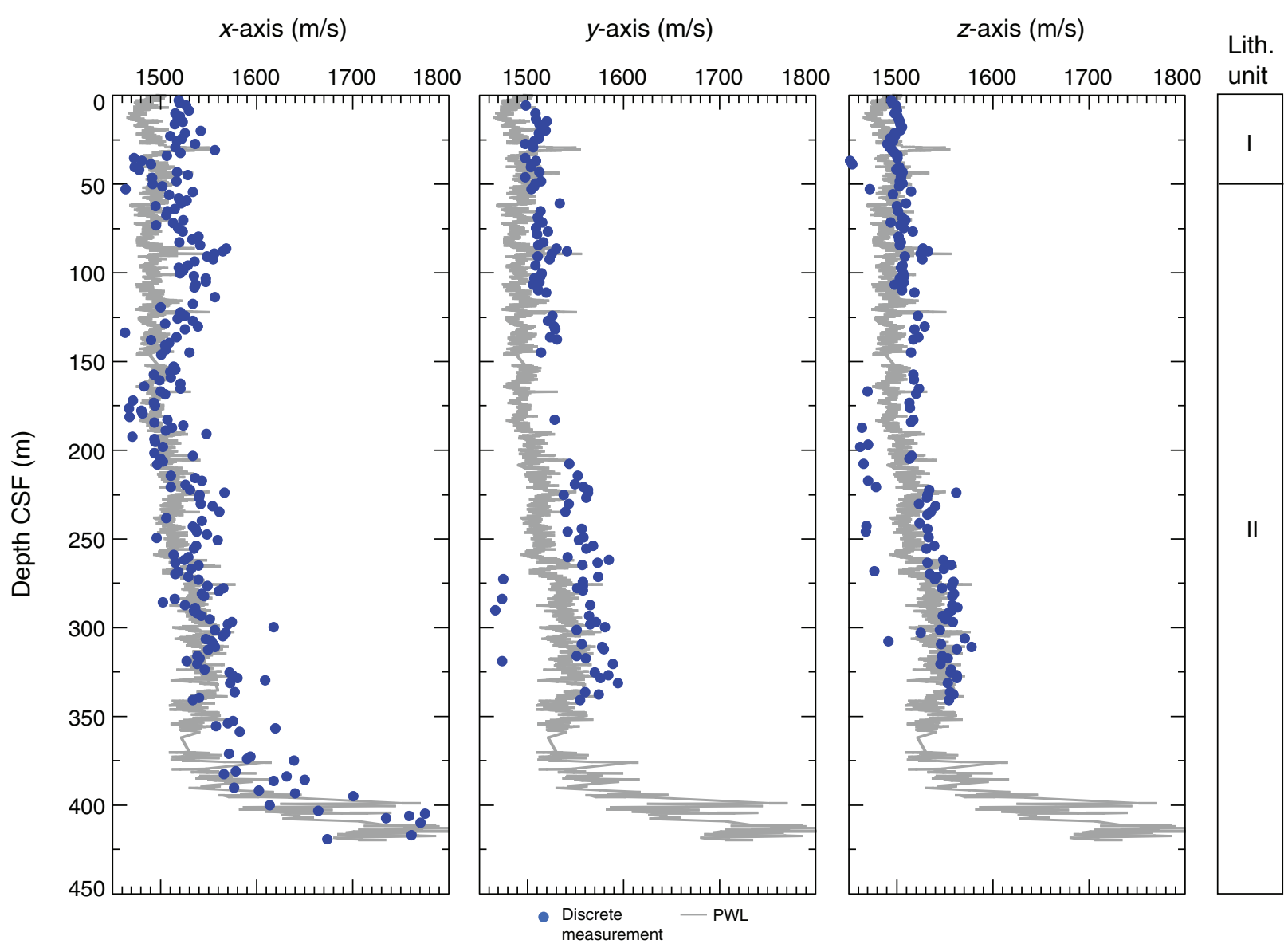
Figure F24. Porosity and thermal conductivity measurements, Hole U1335A.

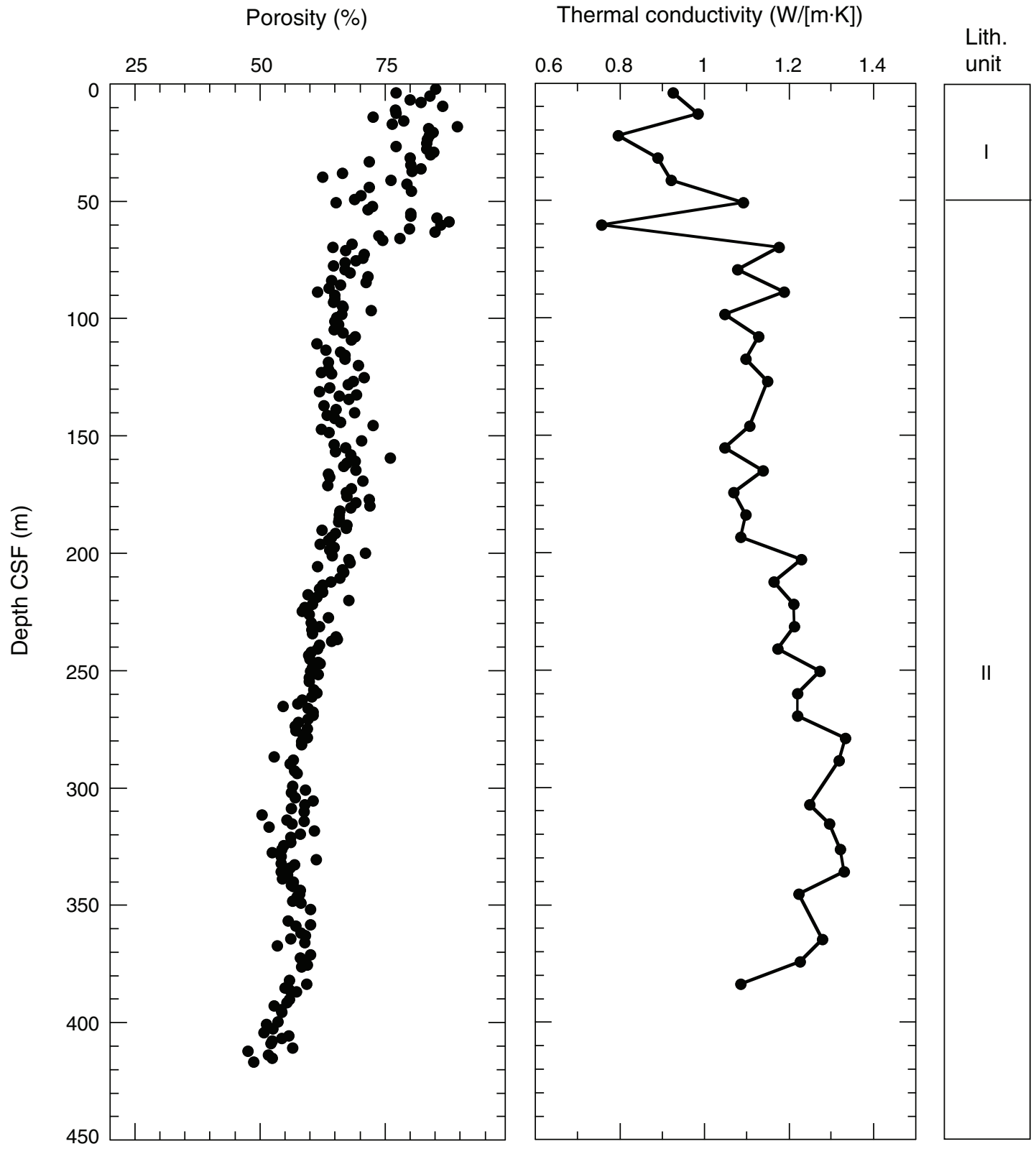


Figure F25. Thermal conductivity vs. porosity, from moisture and density analysis of discrete samples, Hole U1335A.

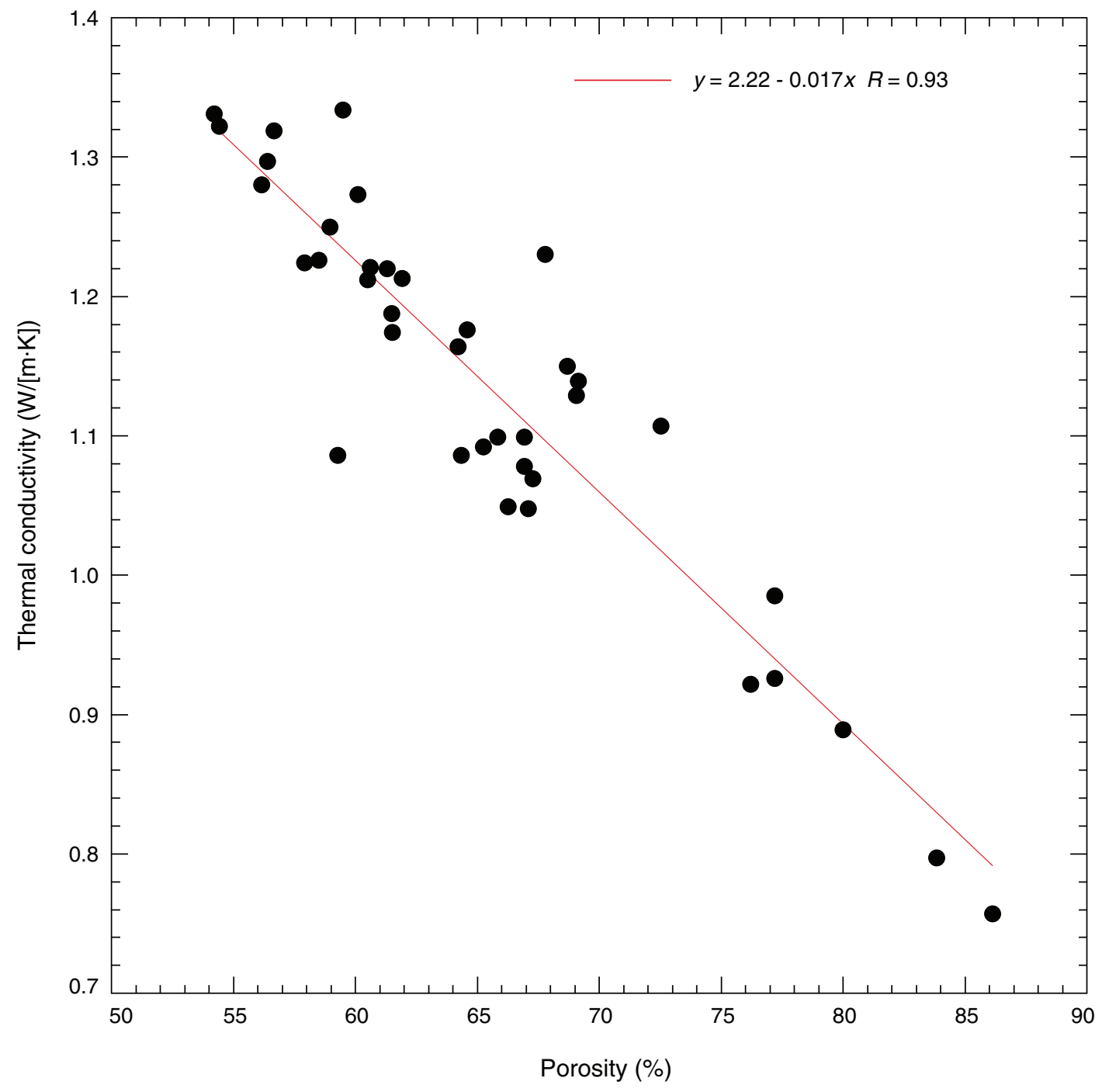


Figure F26. Reflectance spectrophotometer (RSC) data, Holes U1335A and U1335B. RSC for Hole U1335B has been offset ( 20 for $\mathrm{L}^{*}, 4$ for $\mathrm{a}^{*}$, and 8 for $\mathrm{b}^{*}$ ) for core to core comparison. $\mathrm{L}^{*}, \mathrm{a}^{*}, \mathrm{~b}^{*}=$ reflectance value of sediment as defined in the LAB color model.

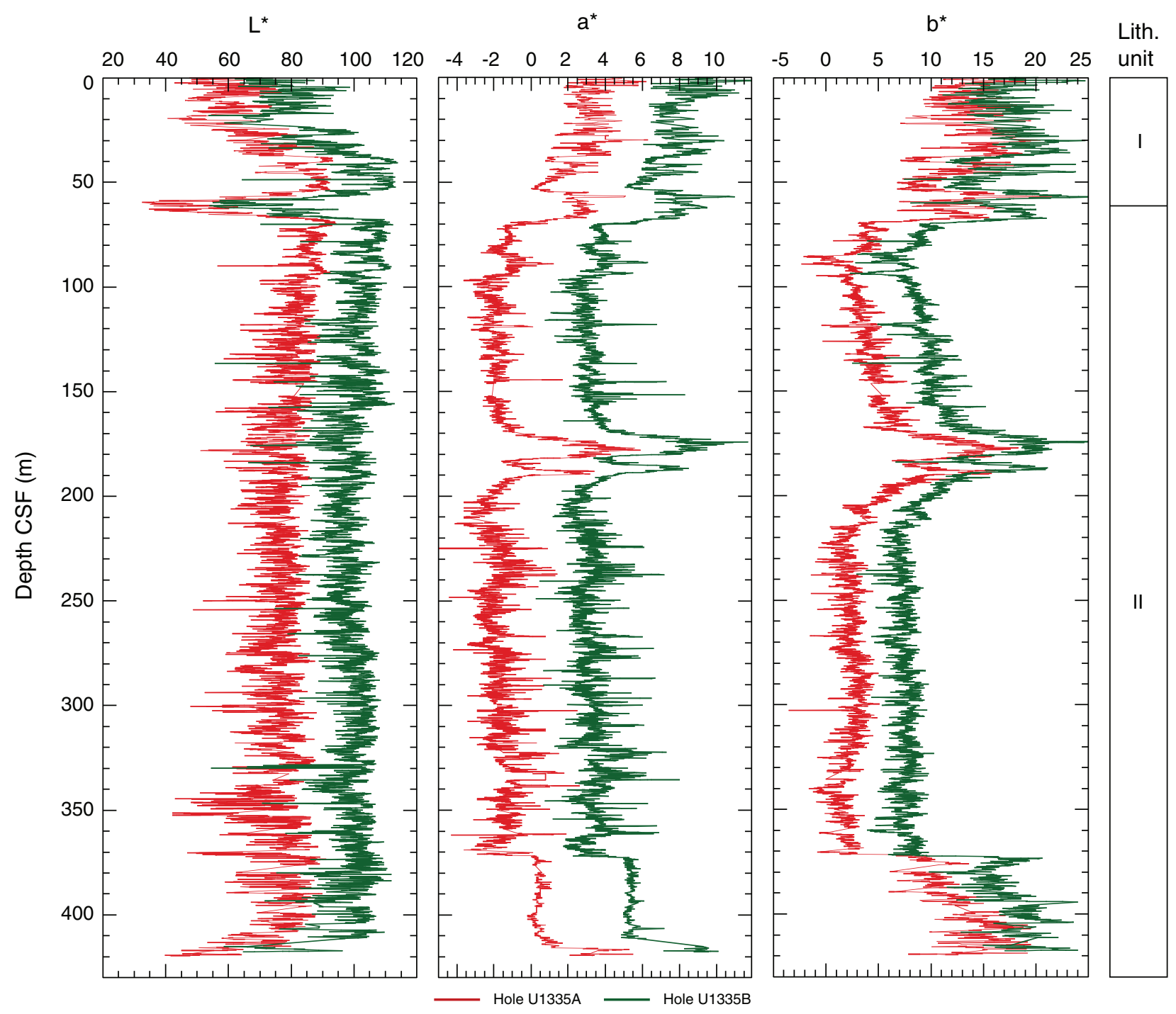


Figure F27. Magnetic susceptibility data, Site U1335. Top panel = spliced section with core breaks (triangles) and hole designations, bottom panel = Holes U1335A (red) and U1335B (blue), offset from each other by a constant $\left(150 \times 10^{-6} \mathrm{SI}\right)$. A. $0-50$ CCSF-A. (Continued on next seven pages.)
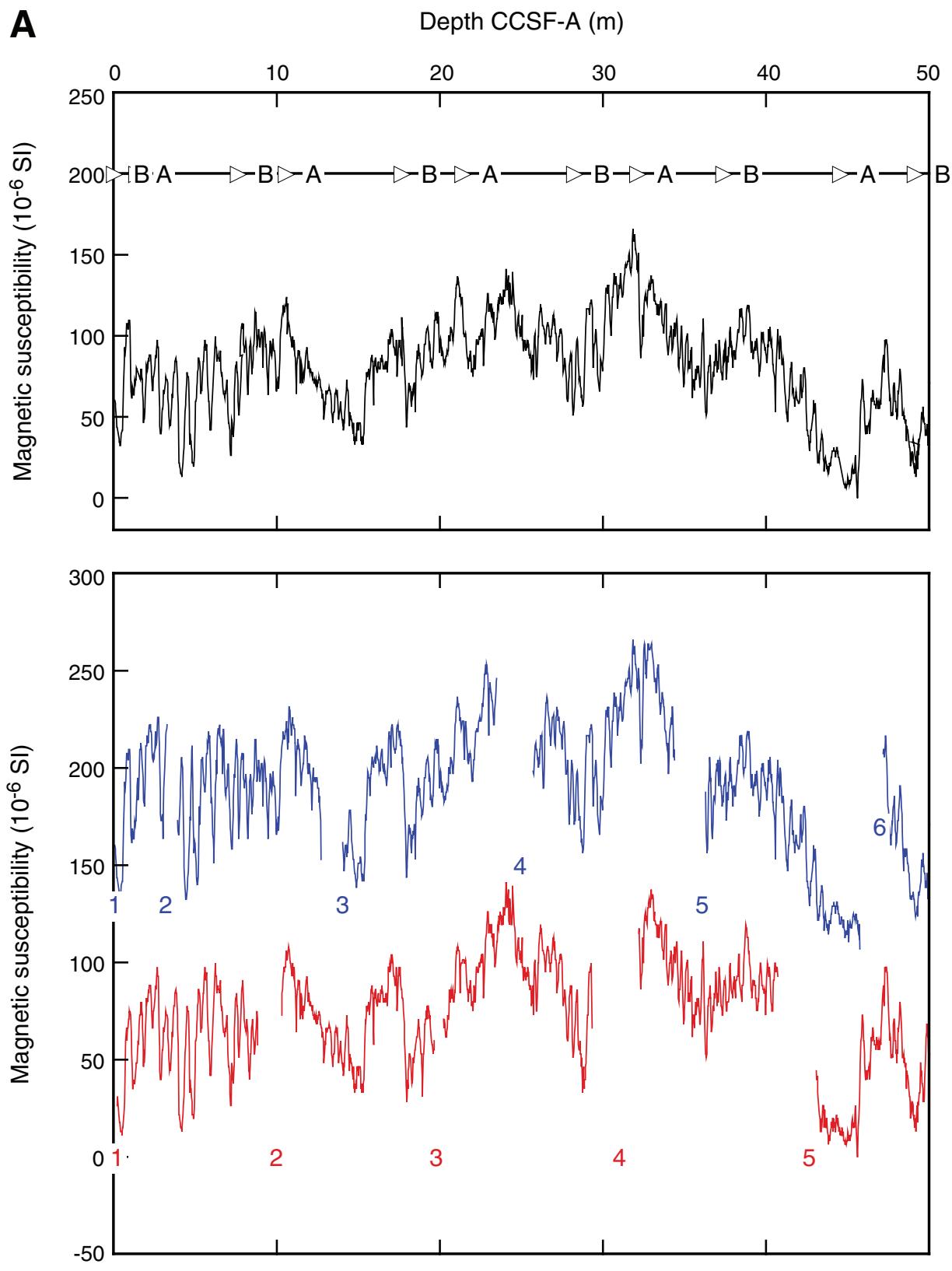
Figure F27 (continued). B. 50-100 CCSF-A. (Continued on next page.)

B

Depth CCSF-A (m)
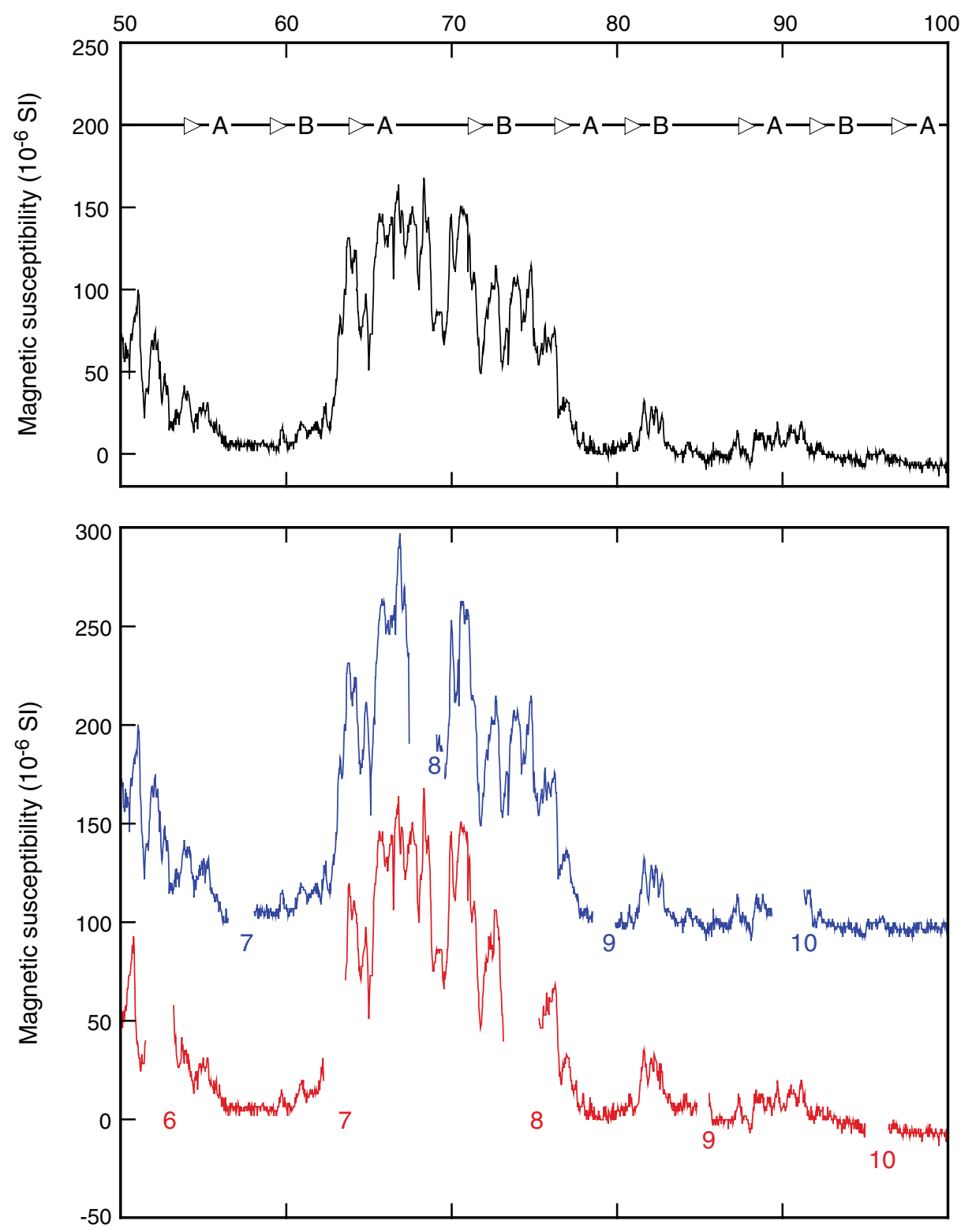
Figure F27 (continued). C. 100-150 CCSF-A. (Continued on next page.)
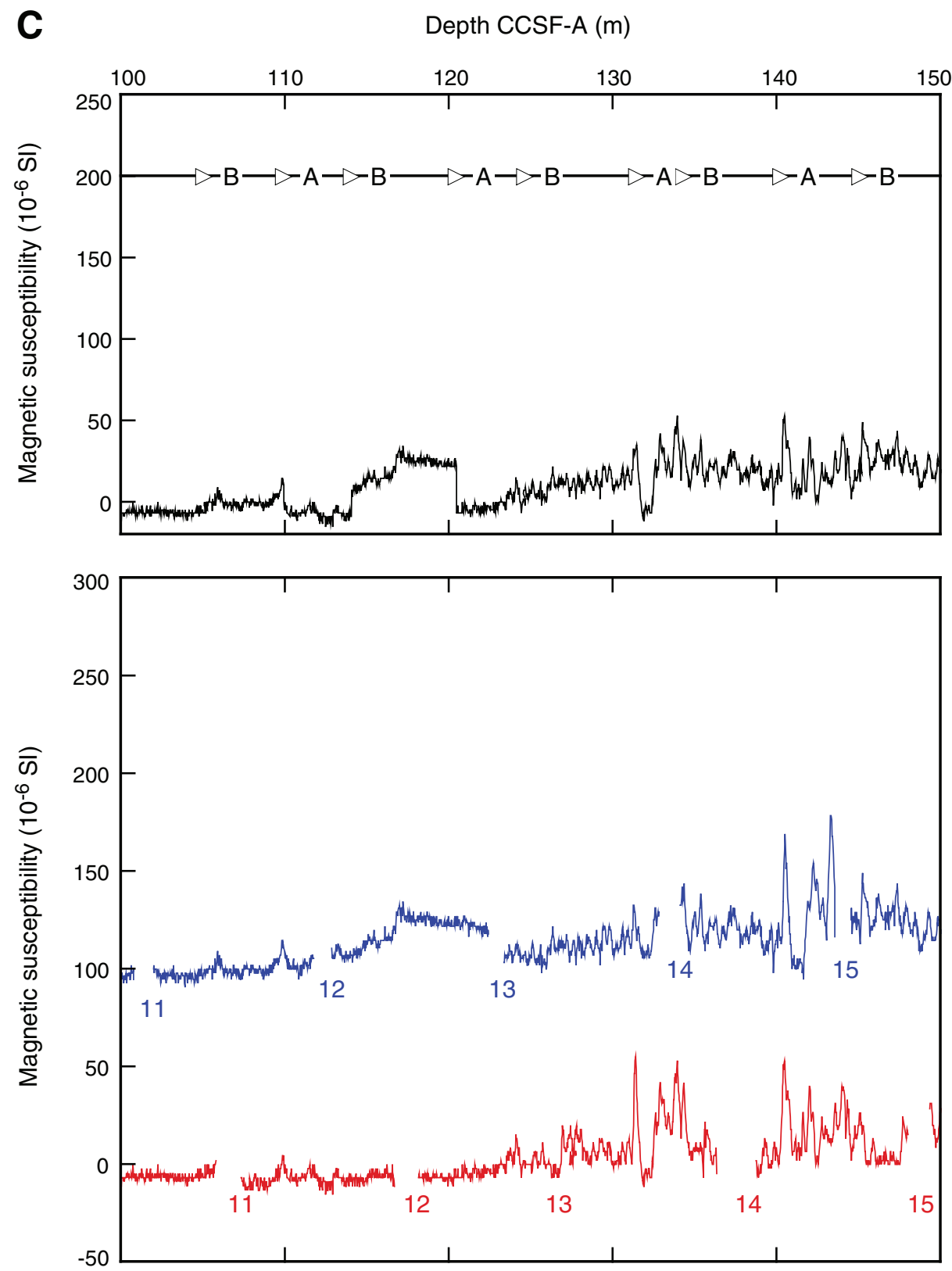
Figure F27 (continued). D. 150-200 CCSF-A. (Continued on next page.)
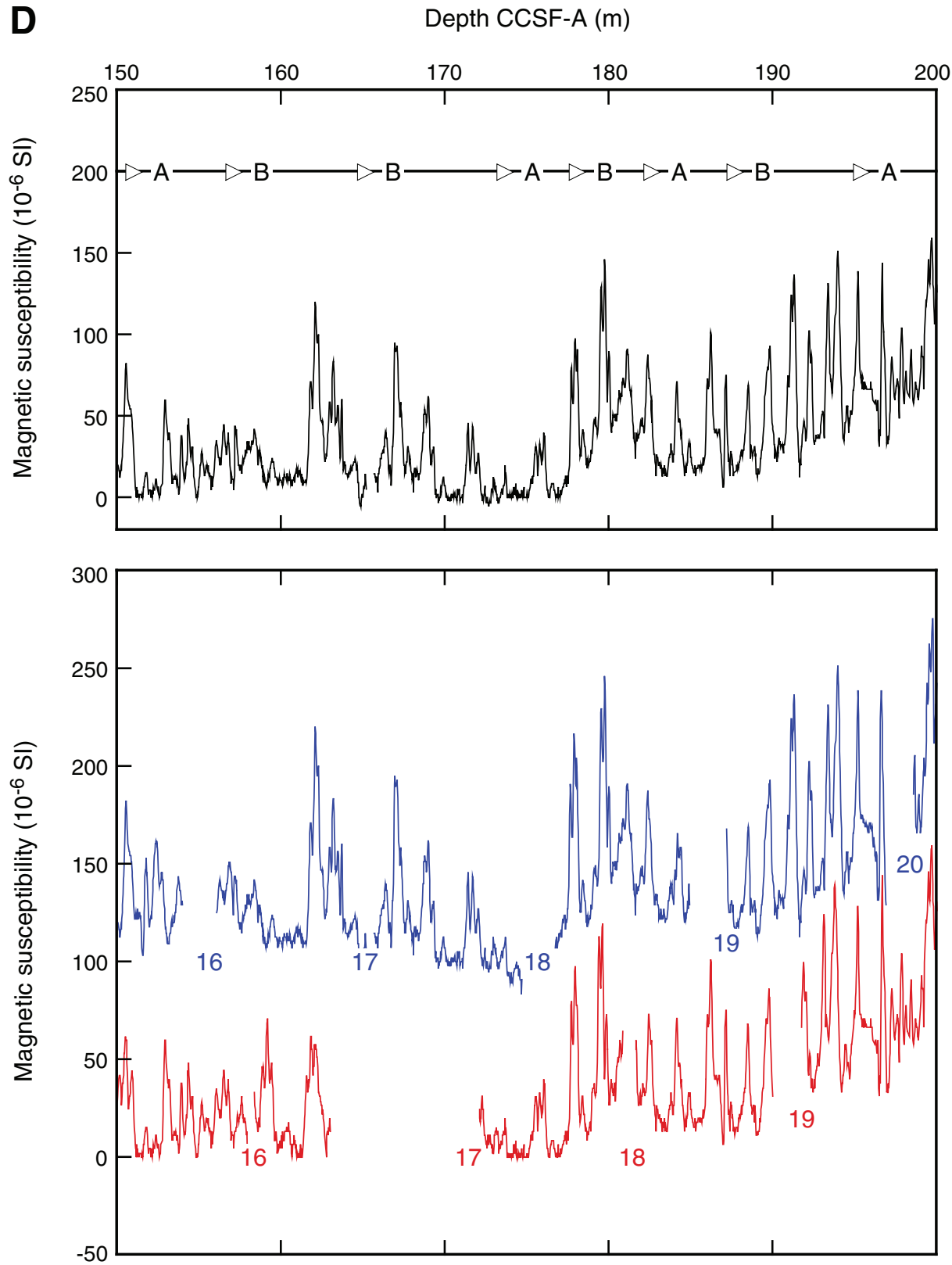
Figure F27 (continued). E. 200-250 CCSF-A. (Continued on next page.)

E

Depth CCSF-A (m)
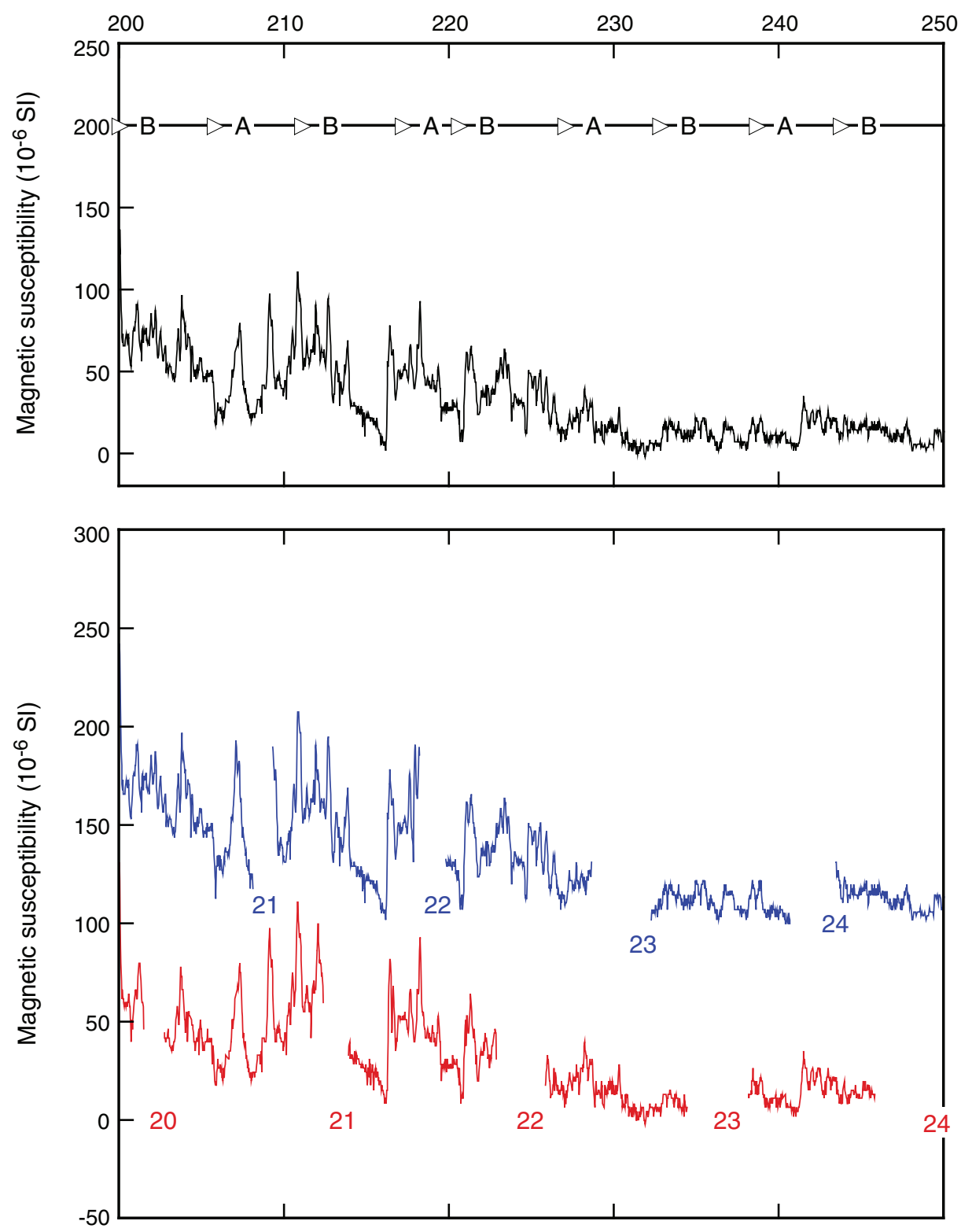
Figure F27 (continued). F. 250-300 CCSF-A. (Continued on next page.)
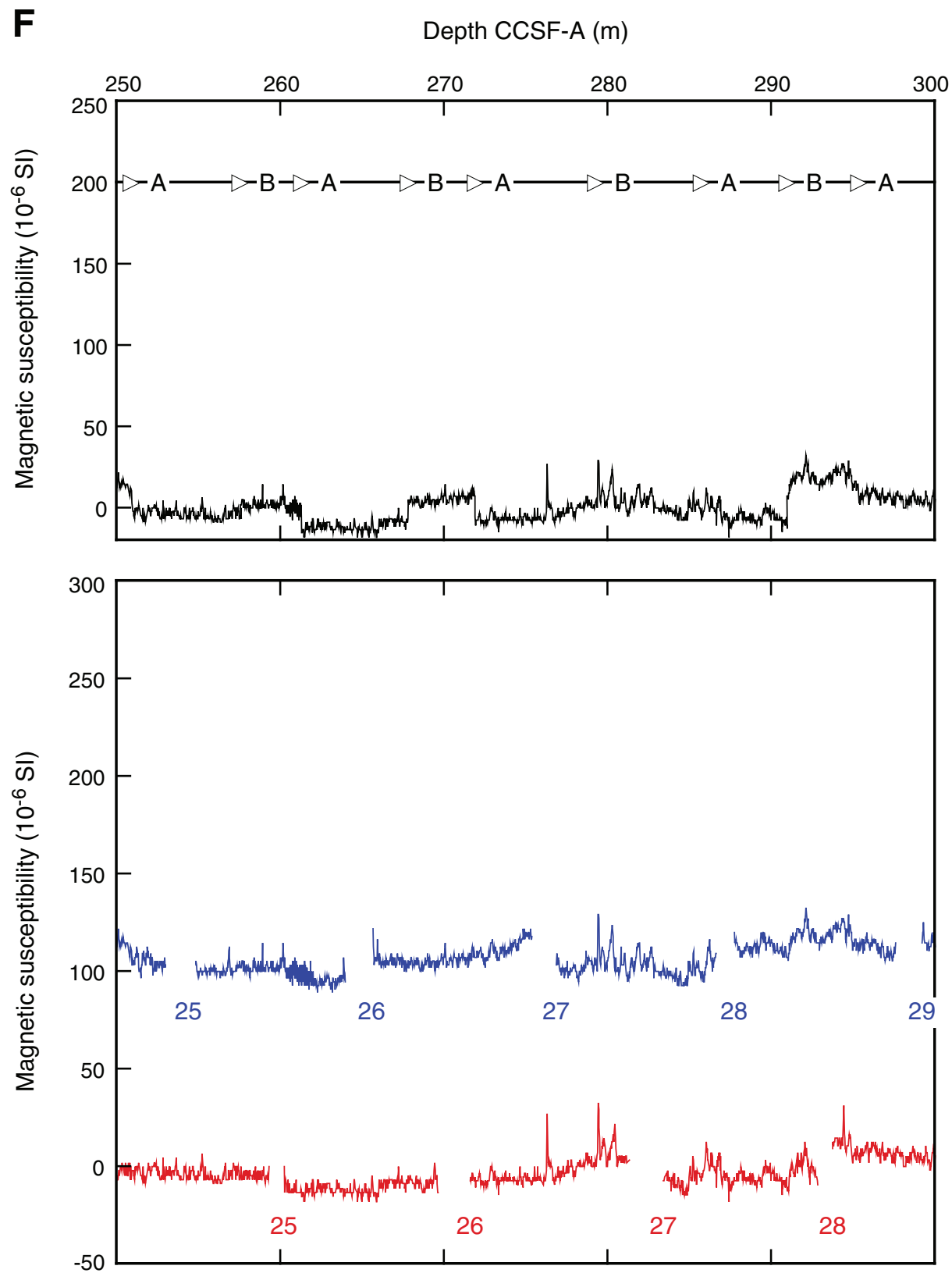
Figure F27 (continued). G. 300-350 CCSF-A. (Continued on next page.)
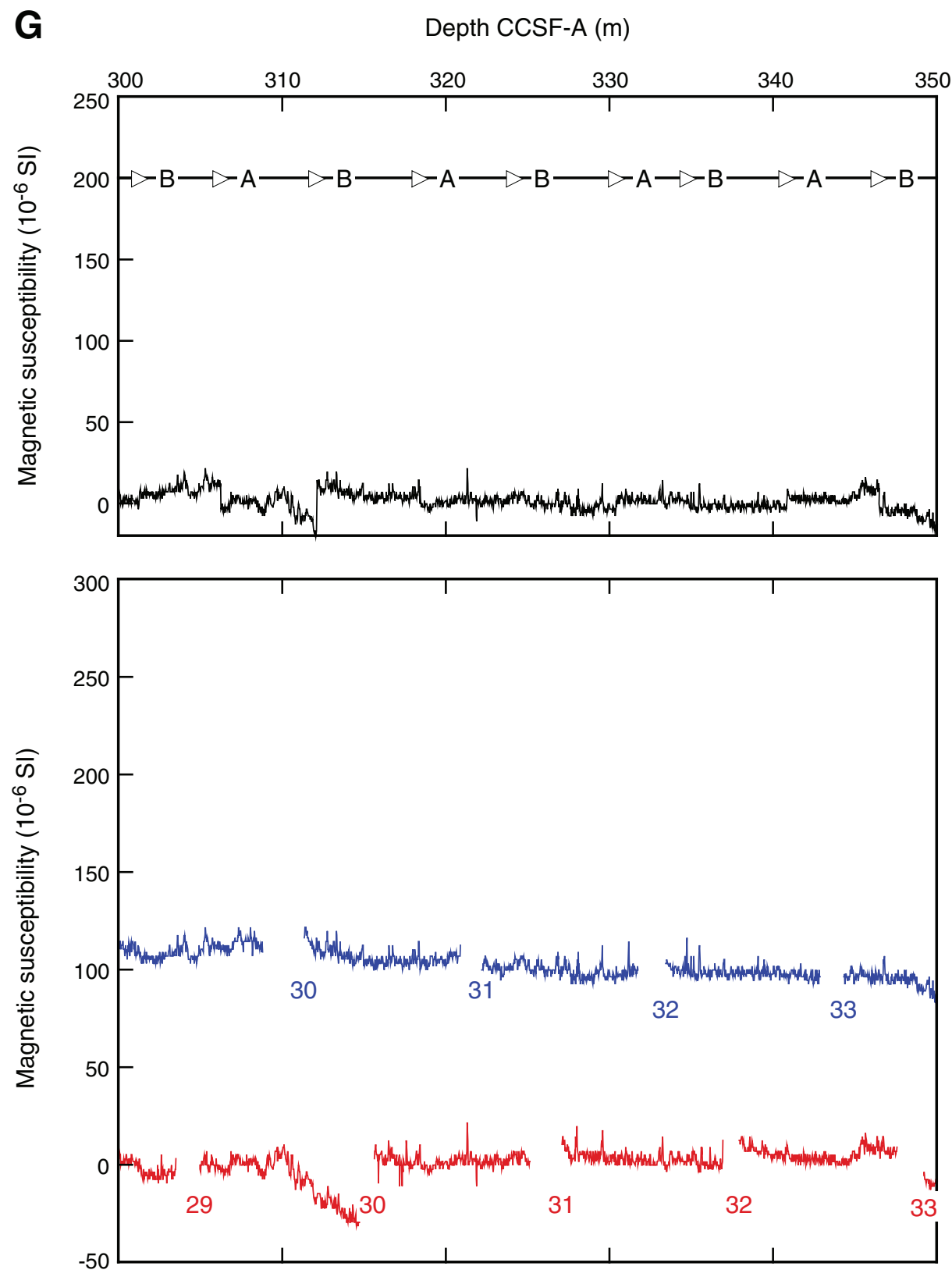
Figure F27 (continued). H. 350-400 CCSF-A.
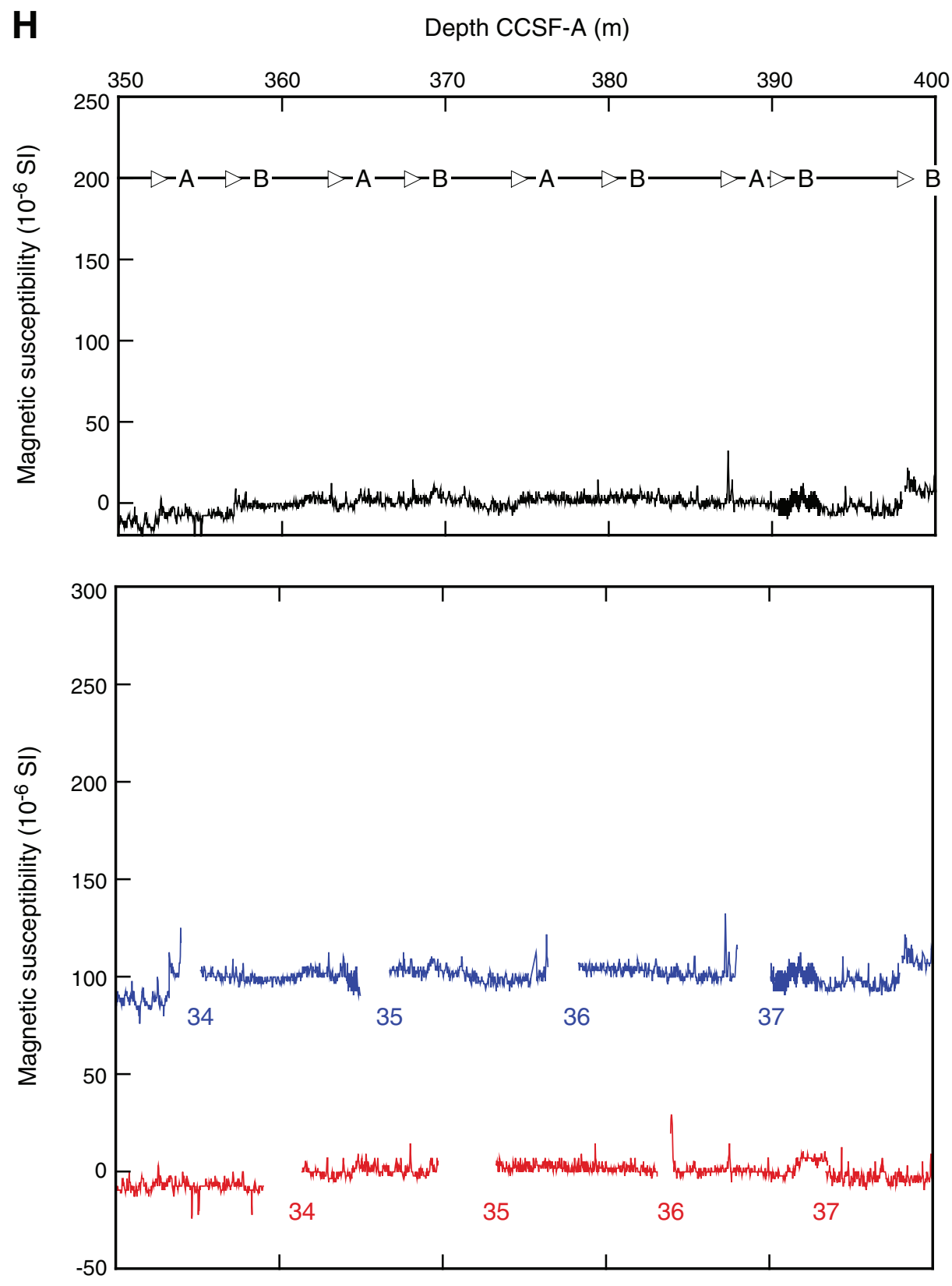
Figure F28. Gamma ray attenuation (GRA) density data, Site U1335. Top panel = spliced section with core breaks (triangles) and hole designations, bottom panel = Holes U1335A (red) and U1335B (blue), offset from each other by a constant $\left(0.8 \mathrm{~g} / \mathrm{cm}^{3}\right)$. A. 0-50 CCSF-A. (Continued on next seven pages.)

A

Depth CCSF-A (m)
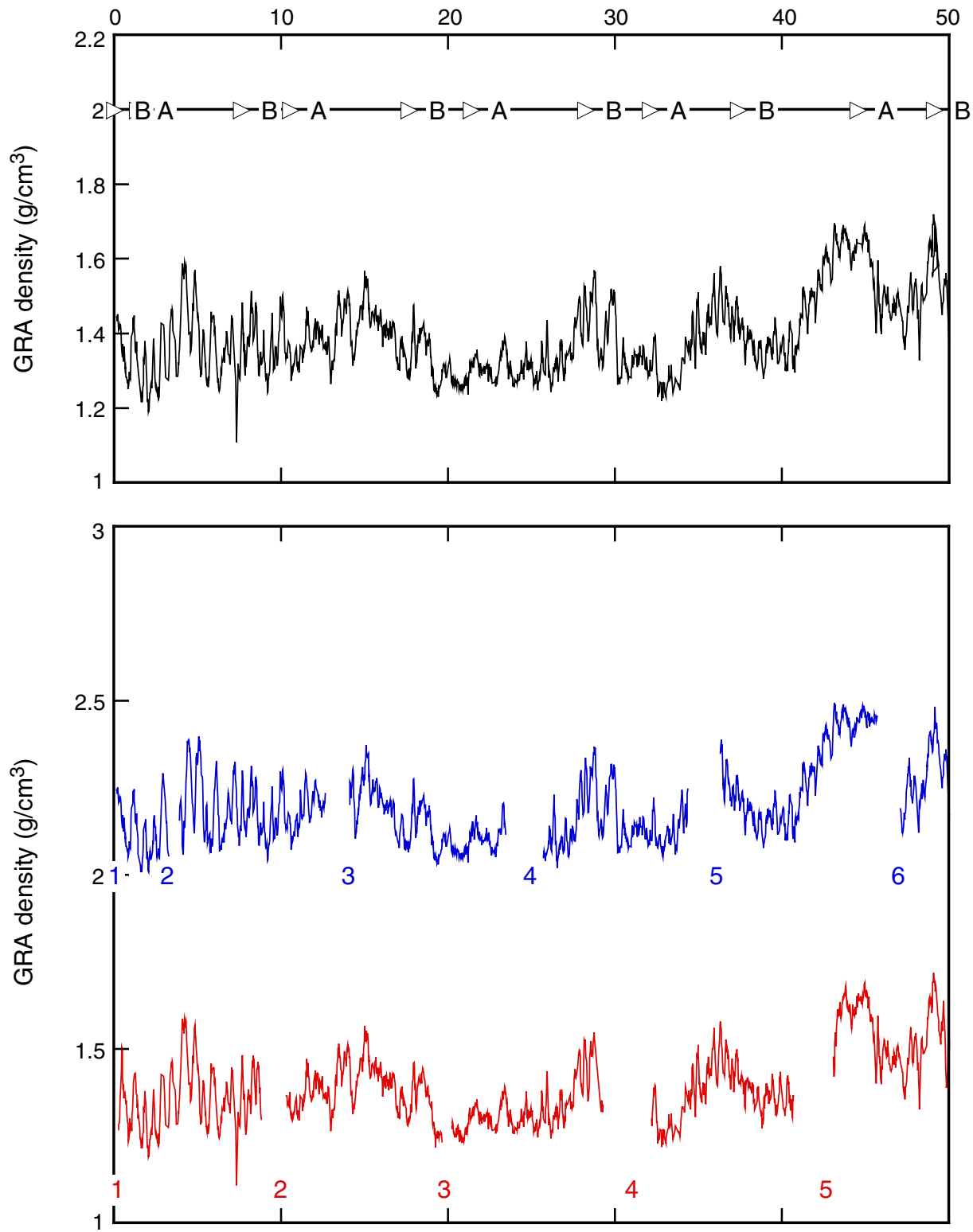
Figure F28 (continued). B. 50-100 CCSF-A. (Continued on next page.)
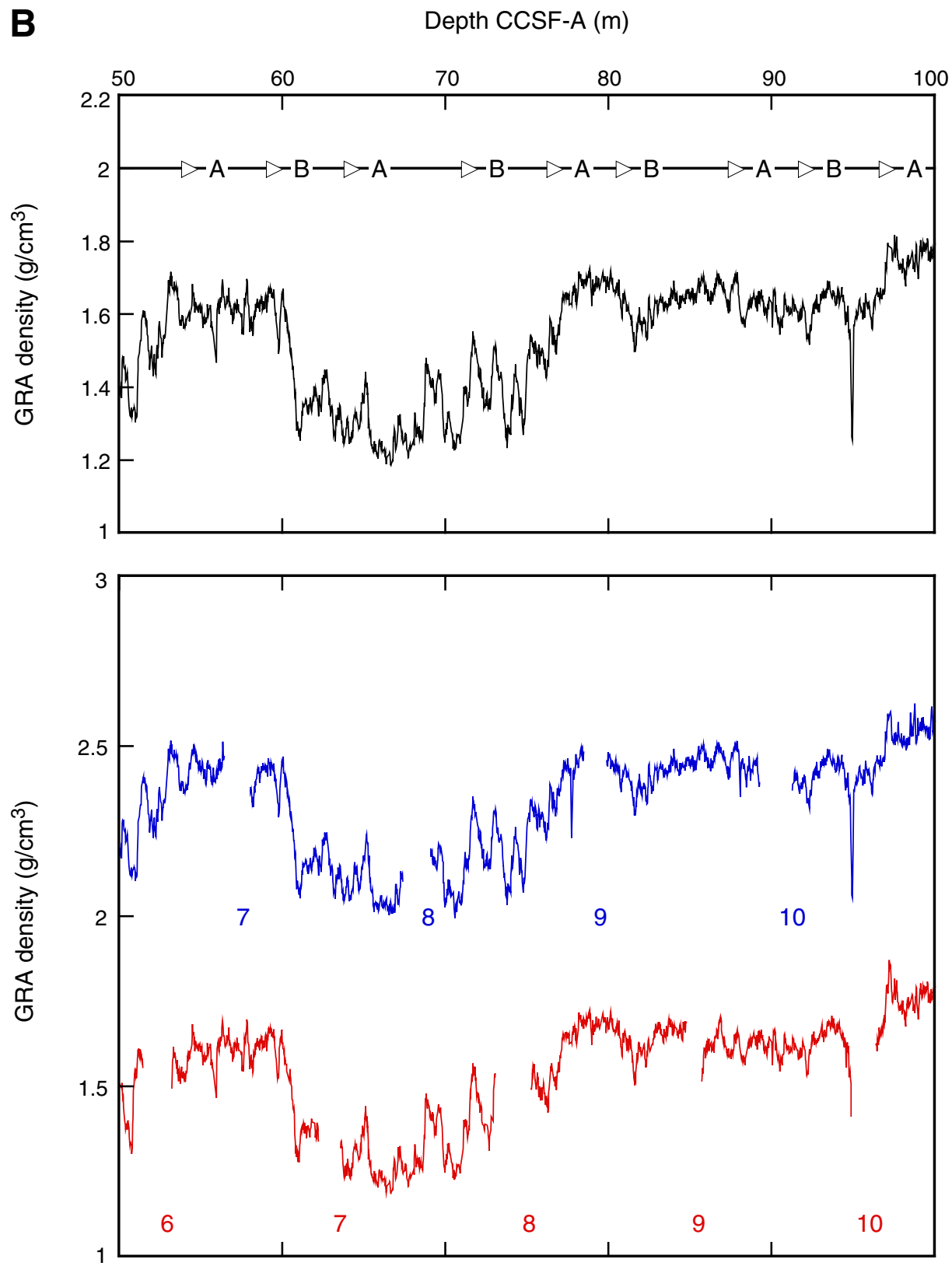
Figure F28 (continued). C. 100-150 CCSF-A. (Continued on next page.)
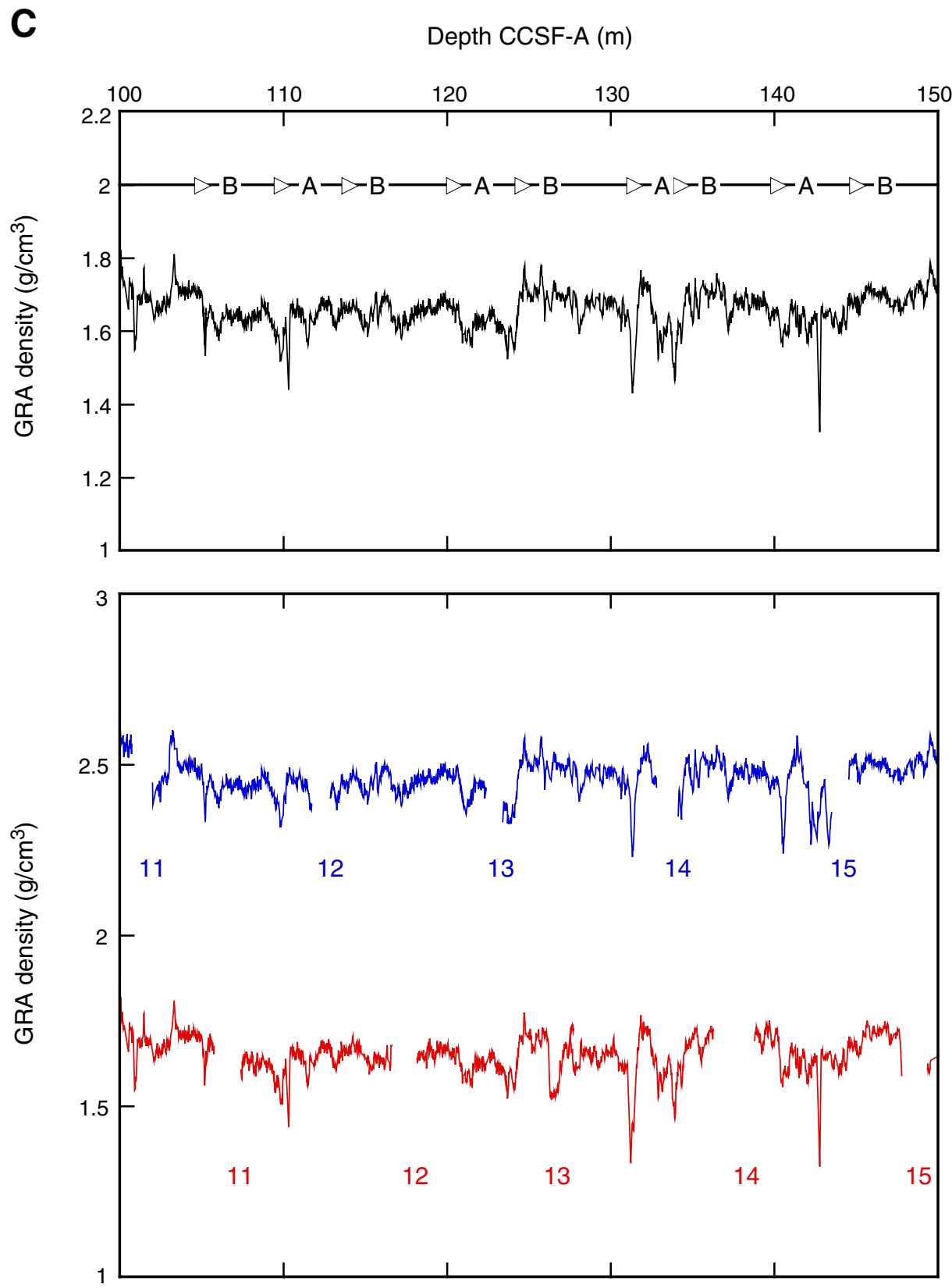
Figure F28 (continued). D. 150-200 CCSF-A. (Continued on next page.)
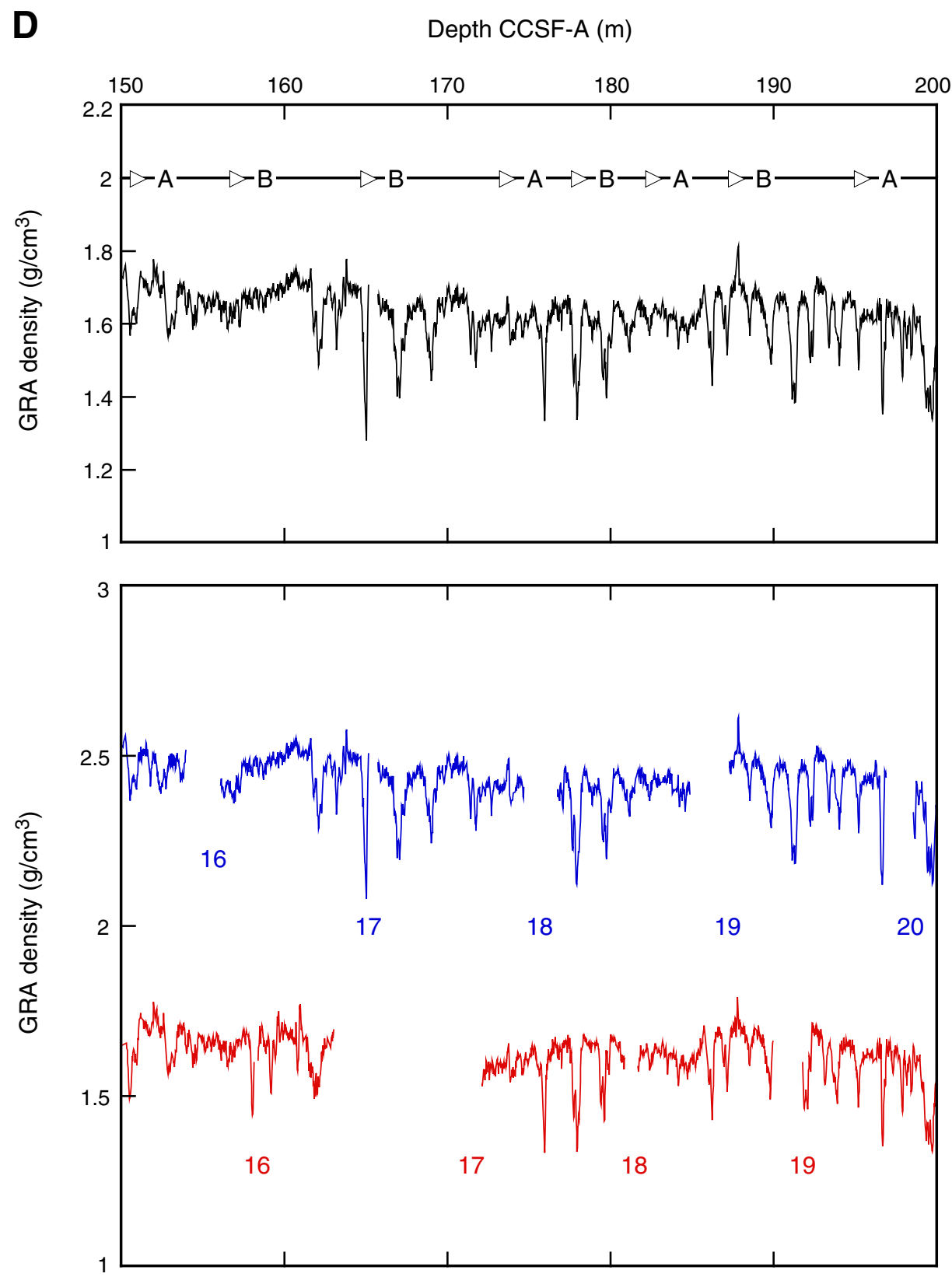
Figure F28 (continued). E. 200-250 CCSF-A. (Continued on next page.)

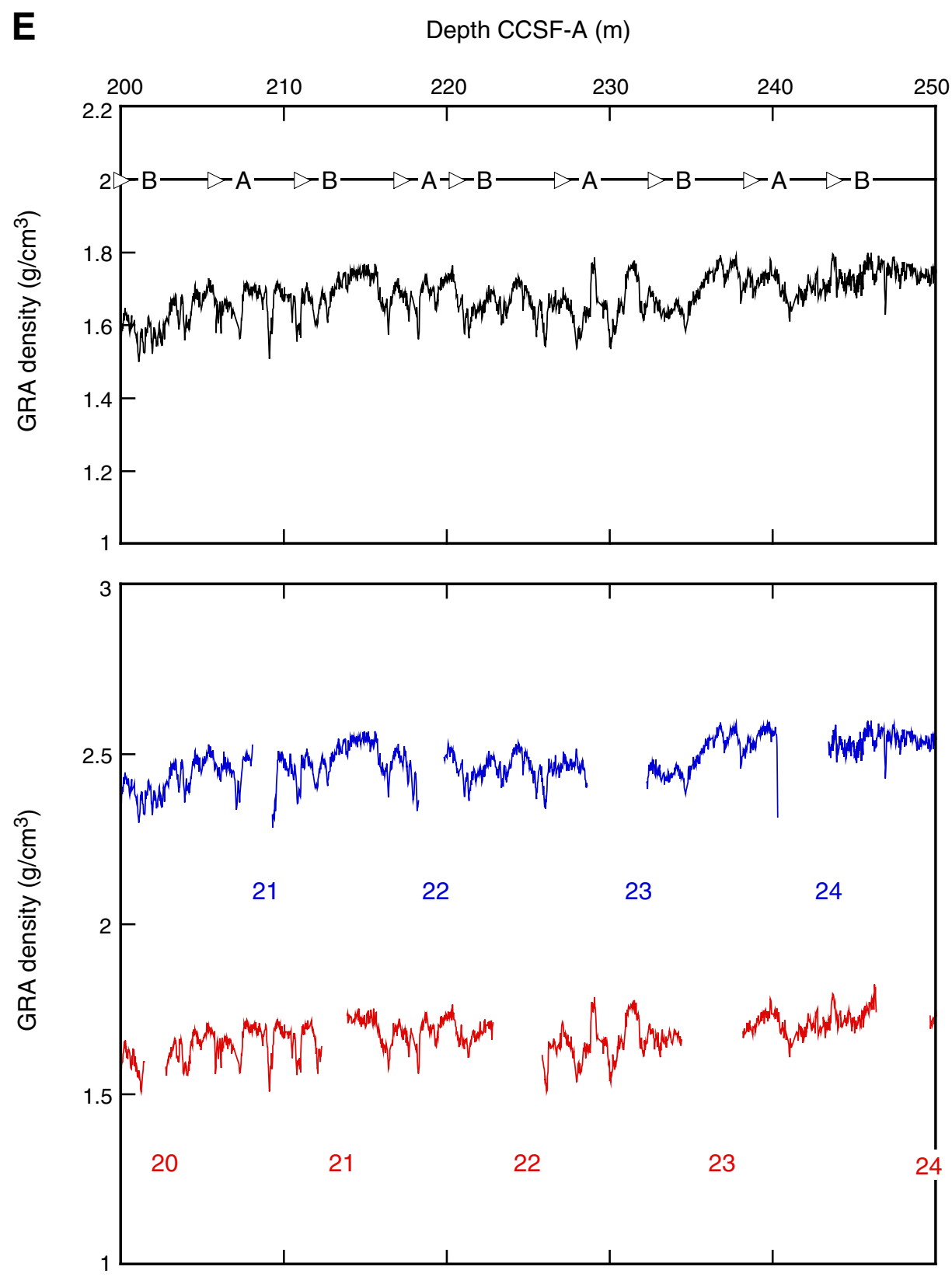


Figure F28 (continued). F. 250-300 CCSF-A. (Continued on next page.)
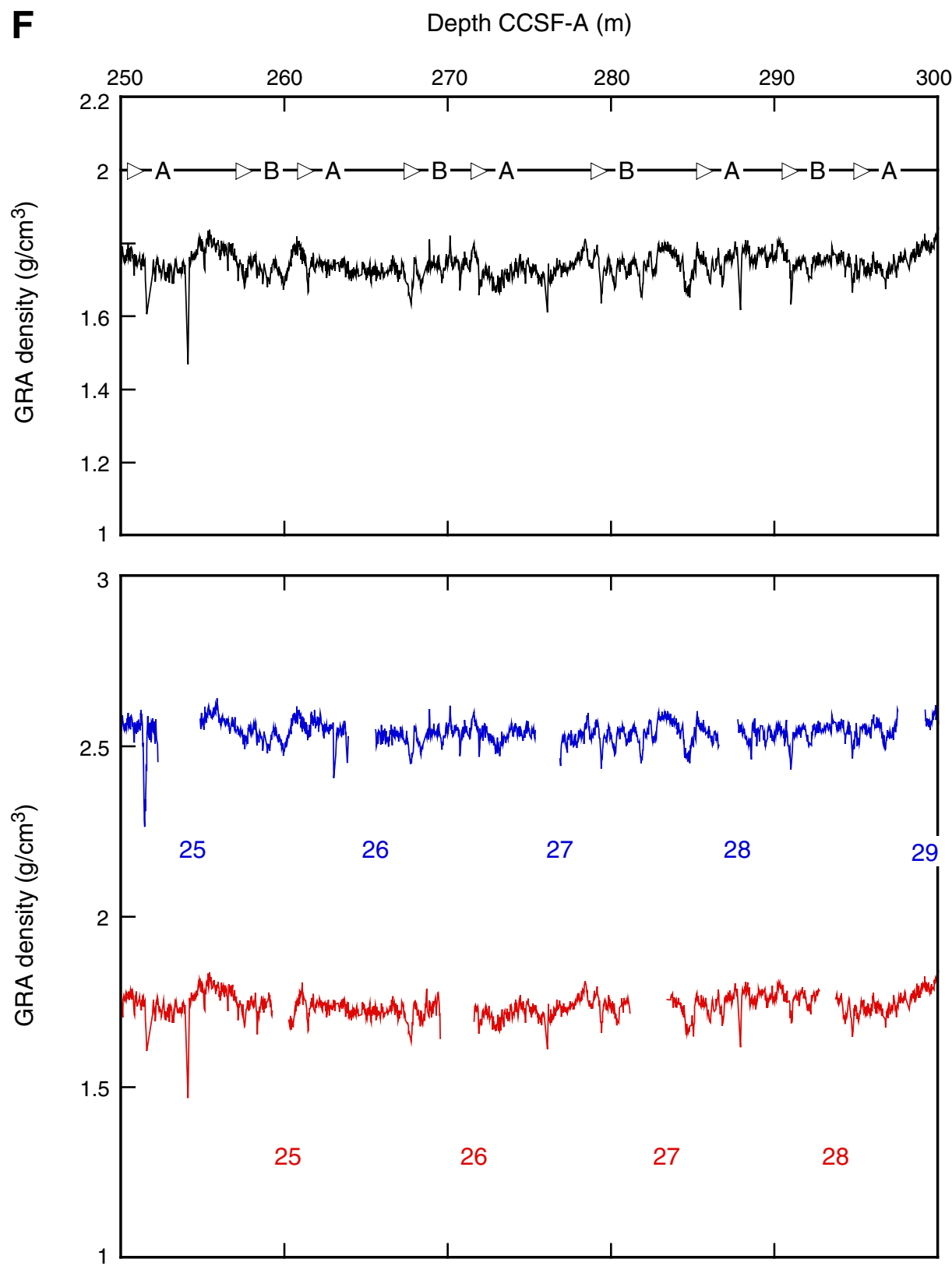
Figure F28 (continued). G. 300-350 CCSF-A. (Continued on next page.)

G Depth CCSF-A (m)
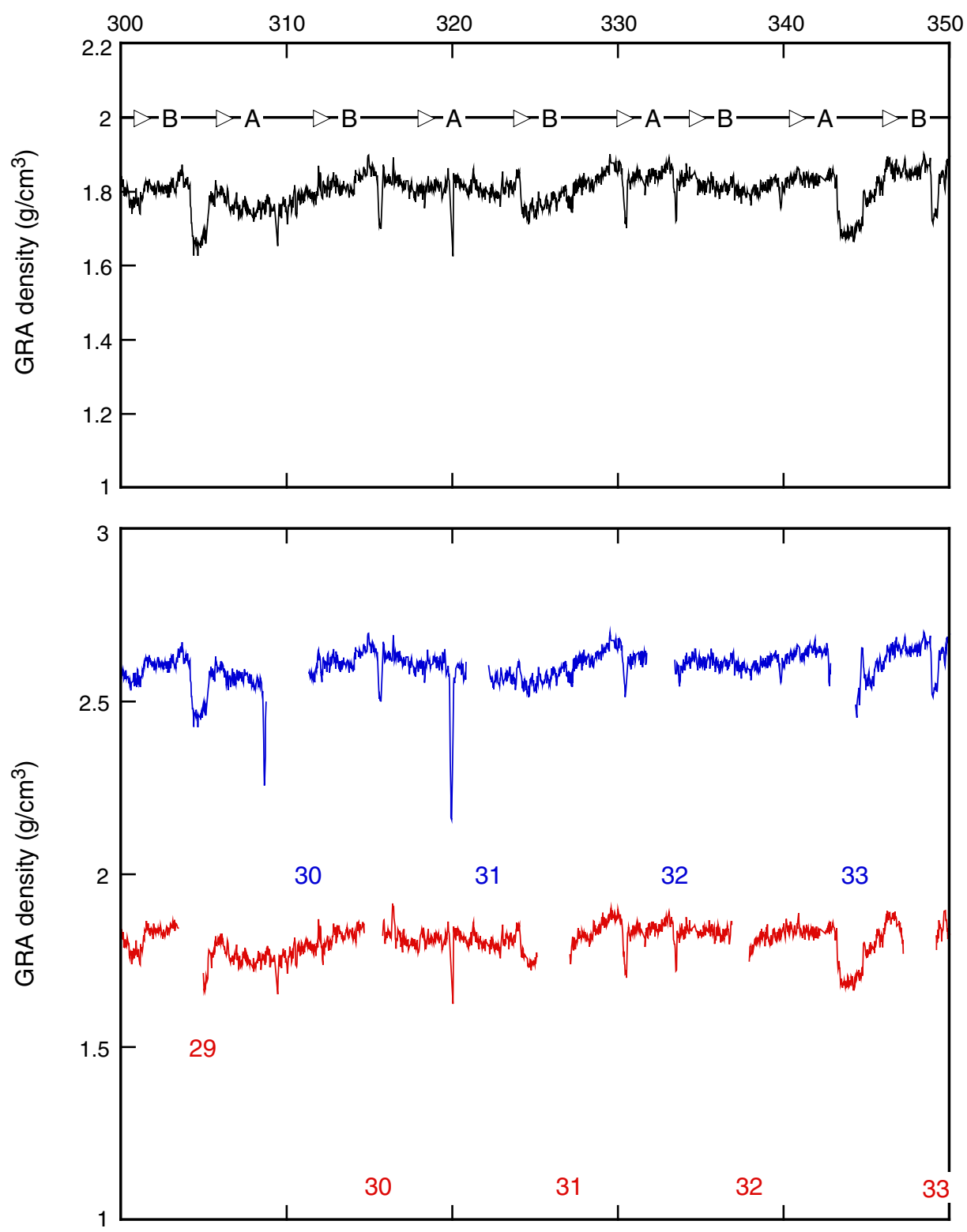
Figure F28 (continued). H. 350-400 CCSF-A.
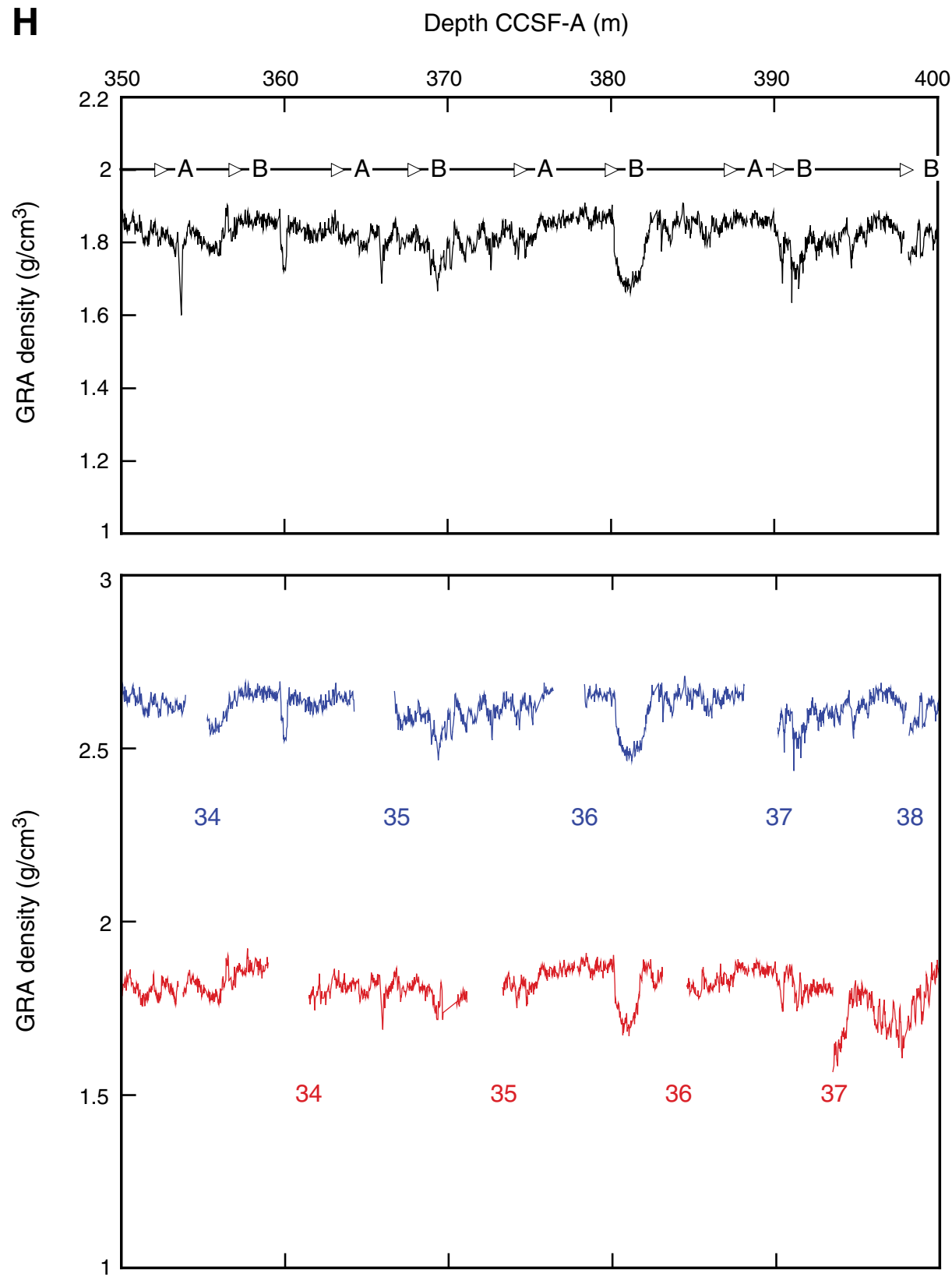
Figure F29. CSF depth vs. CCSF-A depth for tops of cores, Site U1335. Growth factor = slope of the regression line. On average, CCSF-A depth of spliced section is $16 \%$ greater than CSF depth.

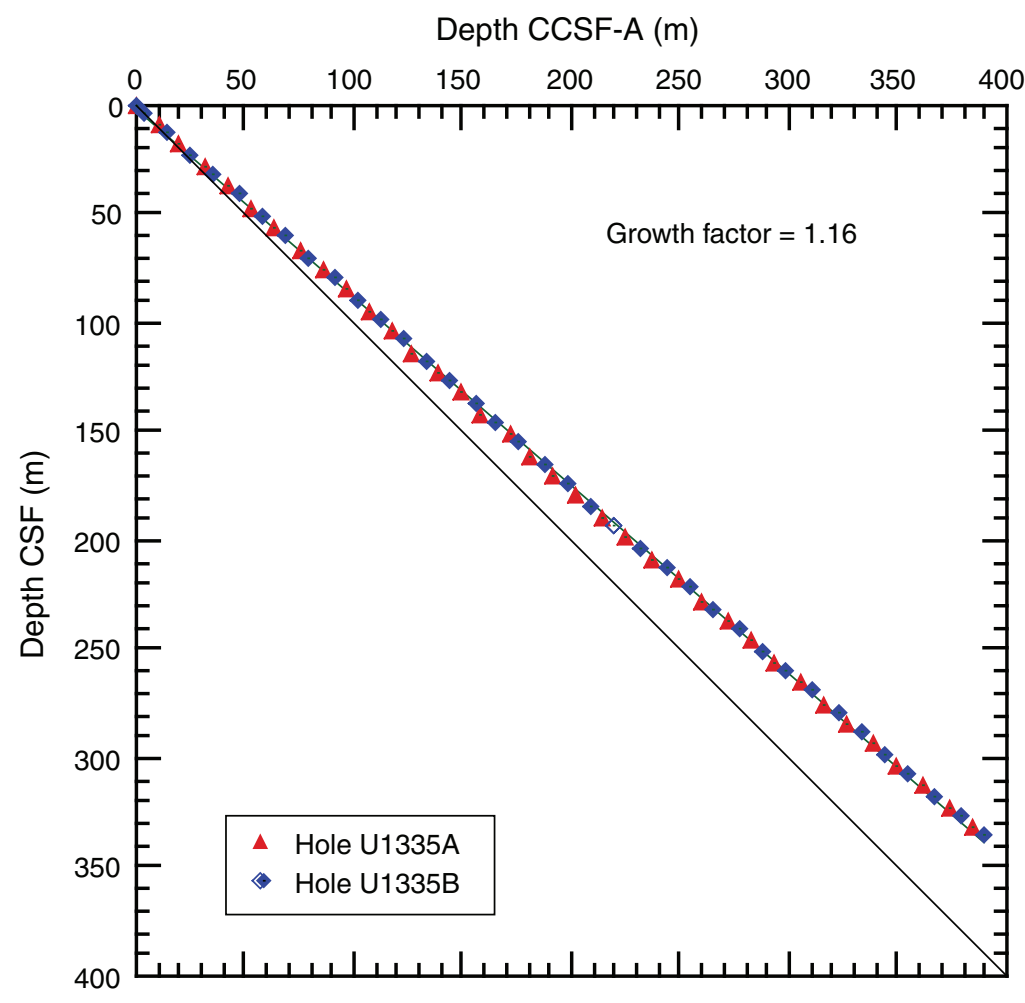


Figure F30. Heat flow calculation, Site U1335. A. Sediment temperatures, Hole U1335B. B. Thermal resistance based on laboratory thermal conductivity data, Hole U1335A. C. Bullard plot where heat flow is calculated from a linear fit of the temperature data. APCT-3 = advanced piston corer temperature tool.

A

APCT-3 temperature $\left({ }^{\circ} \mathrm{C}\right)$

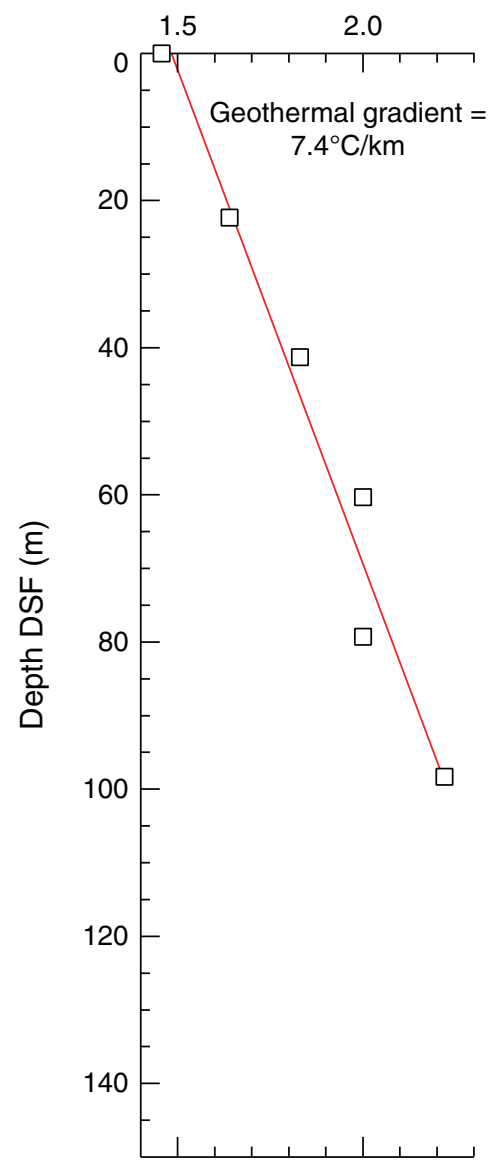

B

Thermal resistance $\left(\mathrm{m}^{2} \mathrm{~K} / \mathrm{W}\right)$

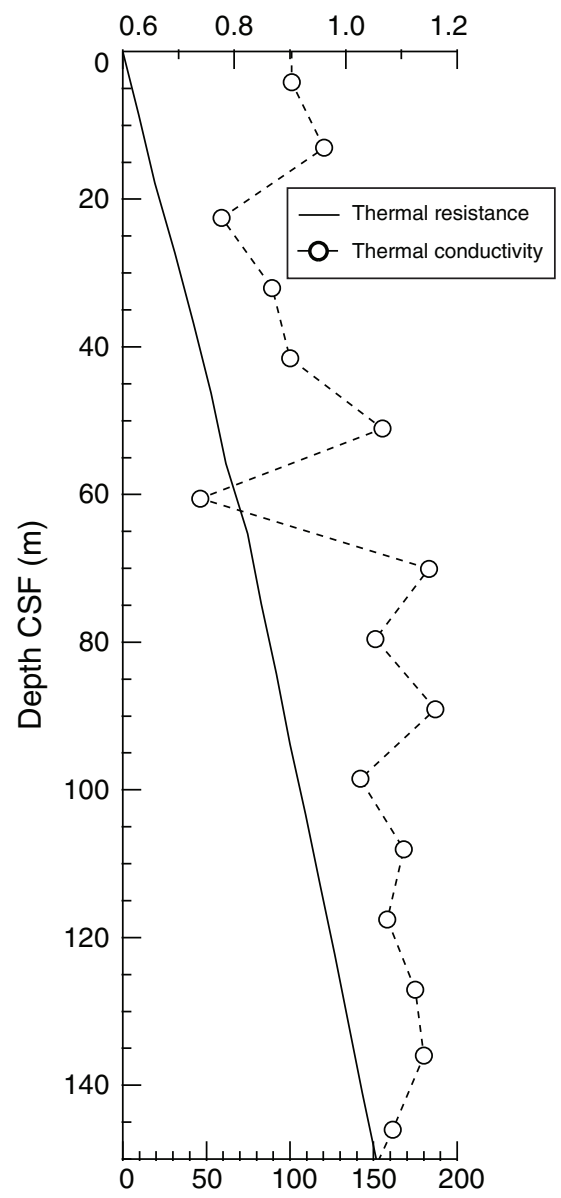

Thermal conductivity $(\mathrm{W} /[\mathrm{m} \cdot \mathrm{K}])$

\section{C} APCT-3 temperature $\left({ }^{\circ} \mathrm{C}\right)$

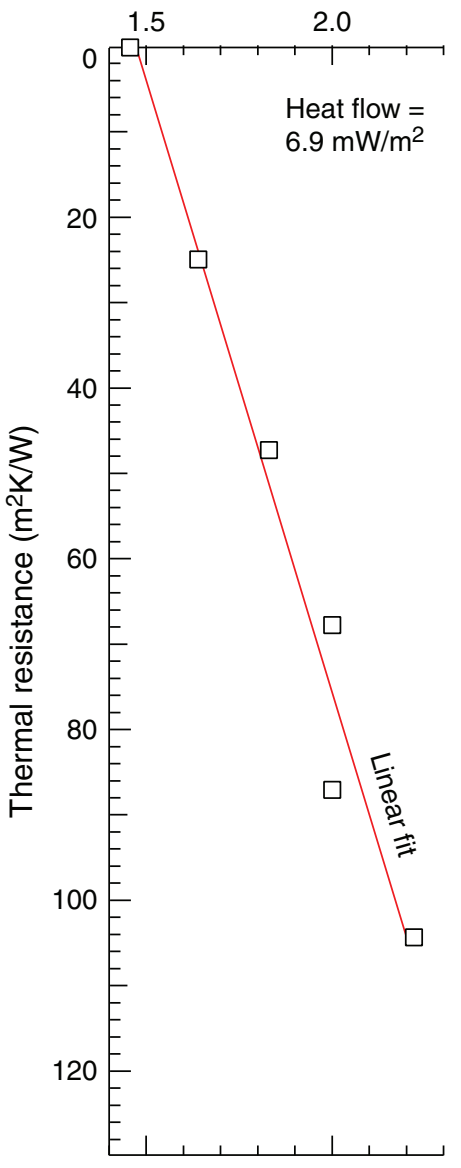


Table T1. Coring summary, Site U1335. (See table notes.) (Continued on next page.)

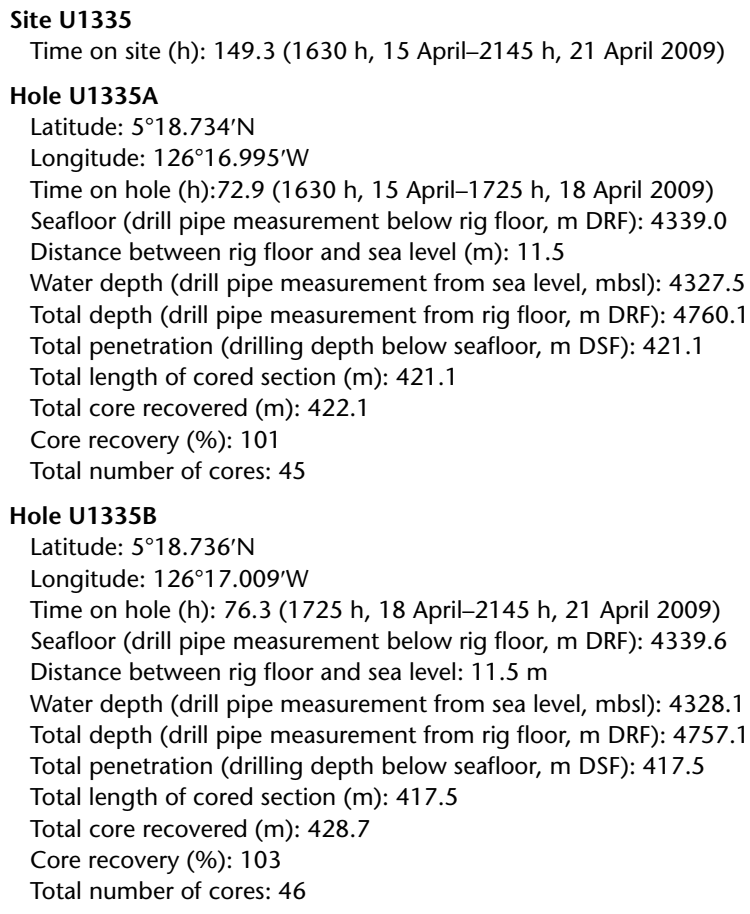

\begin{tabular}{|c|c|c|c|c|c|c|c|c|c|}
\hline \multirow[b]{2}{*}{ Core } & \multirow[b]{2}{*}{$\begin{array}{l}\text { Date } \\
\text { (2009) }\end{array}$} & \multirow[b]{2}{*}{$\begin{array}{l}\text { Local time } \\
\text { (h) }\end{array}$} & \multicolumn{2}{|c|}{ Depth DSF $(m)$} & \multirow[b]{2}{*}{$\begin{array}{l}\text { Interval } \\
\text { advanced } \\
(\mathrm{m})\end{array}$} & \multicolumn{2}{|c|}{ Depth CSF (m) } & \multirow[b]{2}{*}{$\begin{array}{l}\text { Length of core } \\
\text { recovered } \\
(\mathrm{m})\end{array}$} & \multirow[b]{2}{*}{$\begin{array}{l}\text { Recovery } \\
\text { (\%) }\end{array}$} \\
\hline & & & $\begin{array}{l}\text { Top of } \\
\text { cored } \\
\text { interval }\end{array}$ & $\begin{array}{l}\text { Bottom of } \\
\text { cored } \\
\text { interval }\end{array}$ & & $\begin{array}{l}\text { Top of } \\
\text { cored } \\
\text { interval }\end{array}$ & $\begin{array}{l}\text { Bottom of } \\
\text { cored } \\
\text { interval }\end{array}$ & & \\
\hline \multicolumn{10}{|c|}{ 320-U1335A- } \\
\hline $1 \mathrm{H}$ & $16 \mathrm{Apr}$ & 0420 & 0.0 & 8.9 & 8.9 & 0.00 & 8.90 & 8.86 & 100 \\
\hline $2 \mathrm{H}$ & $16 \mathrm{Apr}$ & 0530 & 8.9 & 18.4 & 9.5 & 8.90 & 18.90 & 10.00 & 105 \\
\hline $3 \mathrm{H}$ & $16 \mathrm{Apr}$ & 0620 & 18.4 & 27.9 & 9.5 & 18.40 & 28.20 & 9.78 & 103 \\
\hline $4 \mathrm{H}$ & $16 \mathrm{Apr}$ & 0725 & 27.9 & 37.4 & 9.5 & 27.90 & 37.85 & 9.95 & 105 \\
\hline $5 \mathrm{H}$ & $16 \mathrm{Apr}$ & 0820 & 37.4 & 46.9 & 9.5 & 37.40 & 46.50 & 9.10 & 96 \\
\hline $6 \mathrm{H}$ & $16 \mathrm{Apr}$ & 0915 & 46.9 & 56.4 & 9.5 & 46.90 & 56.50 & 9.60 & 101 \\
\hline $7 \mathrm{H}$ & $16 \mathrm{Apr}$ & 1010 & 56.4 & 65.9 & 9.5 & 56.40 & 66.30 & 9.89 & 104 \\
\hline $8 \mathrm{H}$ & $16 \mathrm{Apr}$ & 1110 & 65.9 & 75.4 & 9.5 & 65.90 & 75.91 & 10.01 & 105 \\
\hline $9 \mathrm{H}$ & $16 \mathrm{Apr}$ & 1215 & 75.4 & 84.9 & 9.5 & 75.40 & 85.10 & 9.67 & 102 \\
\hline $10 \mathrm{H}$ & $16 \mathrm{Apr}$ & 1320 & 84.9 & 94.4 & 9.5 & 84.90 & 95.00 & 10.09 & 106 \\
\hline $11 \mathrm{H}$ & $16 \mathrm{Apr}$ & 1420 & 94.4 & 103.9 & 9.5 & 94.40 & 104.58 & 9.84 & 107 \\
\hline $12 \mathrm{H}$ & $16 \mathrm{Apr}$ & 1600 & 103.9 & 113.4 & 9.5 & 103.90 & 113.90 & 9.99 & 105 \\
\hline $13 \mathrm{H}$ & $16 \mathrm{Apr}$ & 1655 & 113.4 & 122.9 & 9.5 & 113.40 & 123.44 & 10.04 & 106 \\
\hline $14 \mathrm{H}$ & $16 \mathrm{Apr}$ & 1755 & 122.9 & 132.4 & 9.5 & 122.90 & 133.04 & 10.14 & 107 \\
\hline $15 \mathrm{H}$ & $16 \mathrm{Apr}$ & 1855 & 132.4 & 141.9 & 9.5 & 132.40 & 142.13 & 9.73 & 102 \\
\hline $16 \mathrm{H}$ & $16 \mathrm{Apr}$ & 1955 & 141.9 & 151.4 & 9.5 & 141.90 & 151.53 & 9.63 & 101 \\
\hline $17 \mathrm{H}$ & $16 \mathrm{Apr}$ & 2135 & 151.4 & 160.9 & 9.5 & 151.40 & 161.24 & 9.84 & 104 \\
\hline $18 \mathrm{H}$ & $16 \mathrm{Apr}$ & 2225 & 160.9 & 170.4 & 9.5 & 160.90 & 169.80 & 8.87 & 94 \\
\hline $19 \mathrm{H}$ & $16 \mathrm{Apr}$ & 2335 & 170.4 & 179.9 & 9.5 & 170.40 & 180.50 & 10.06 & 106 \\
\hline $20 \mathrm{H}$ & $17 \mathrm{Apr}$ & 0055 & 179.9 & 189.4 & 9.5 & 179.90 & 189.92 & 10.02 & 105 \\
\hline $21 \mathrm{H}$ & $17 \mathrm{Apr}$ & 0210 & 189.4 & 198.9 & 9.5 & 189.40 & 199.00 & 9.60 & 101 \\
\hline $22 \mathrm{H}$ & $17 \mathrm{Apr}$ & 0335 & 198.9 & 208.4 & 9.5 & 198.90 & 208.70 & 9.80 & 103 \\
\hline $23 \mathrm{H}$ & $17 \mathrm{Apr}$ & 0435 & 208.4 & 217.9 & 9.5 & 208.40 & 218.20 & 9.76 & 103 \\
\hline $24 \mathrm{H}$ & $17 \mathrm{Apr}$ & 0605 & 217.9 & 227.4 & 9.5 & 217.90 & 227.90 & 9.99 & 105 \\
\hline $25 \mathrm{H}$ & $17 \mathrm{Apr}$ & 0710 & 227.4 & 236.9 & 9.5 & 227.40 & 236.90 & 9.50 & 100 \\
\hline $26 \mathrm{H}$ & $17 \mathrm{Apr}$ & 0835 & 236.9 & 246.4 & 9.5 & 236.90 & 246.83 & 9.93 & 105 \\
\hline $27 \mathrm{H}$ & $17 \mathrm{Apr}$ & 1005 & 246.4 & 255.9 & 9.5 & 246.40 & 256.24 & 9.84 & 104 \\
\hline $28 \mathrm{H}$ & $17 \mathrm{Apr}$ & 1110 & 255.9 & 265.4 & 9.5 & 255.90 & 266.01 & 10.11 & 106 \\
\hline $29 \mathrm{H}$ & $17 \mathrm{Apr}$ & 1210 & 265.4 & 274.9 & 9.5 & 265.40 & 275.61 & 10.21 & 107 \\
\hline $30 \mathrm{H}$ & $17 \mathrm{Apr}$ & 1310 & 274.9 & 284.4 & 9.5 & 274.90 & 284.82 & 9.92 & 104 \\
\hline $31 \mathrm{H}$ & $17 \mathrm{Apr}$ & 1415 & 284.4 & 293.9 & 9.5 & 284.40 & 294.55 & 10.15 & 107 \\
\hline $32 \mathrm{H}$ & $17 \mathrm{Apr}$ & 1520 & 293.9 & 303.4 & 9.5 & 293.90 & 303.80 & 9.85 & 104 \\
\hline $33 \mathrm{H}$ & $17 \mathrm{Apr}$ & 1625 & 303.4 & 312.9 & 9.5 & 303.40 & 313.53 & 10.13 & 107 \\
\hline $34 \mathrm{H}$ & $17 \mathrm{Apr}$ & 1750 & 312.9 & 322.4 & 9.5 & 312.90 & 323.05 & 10.15 & 107 \\
\hline $35 \mathrm{H}$ & $17 \mathrm{Apr}$ & 1940 & 322.4 & 331.9 & 9.5 & 322.40 & 332.64 & 10.24 & 108 \\
\hline
\end{tabular}


Table T1 (continued).

\begin{tabular}{|c|c|c|c|c|c|c|c|c|c|}
\hline \multirow[b]{2}{*}{ Core } & \multirow[b]{2}{*}{$\begin{array}{l}\text { Date } \\
(2009)\end{array}$} & \multirow[b]{2}{*}{$\begin{array}{l}\text { Local time } \\
\text { (h) }\end{array}$} & \multicolumn{2}{|c|}{ Depth DSF (m) } & \multirow[b]{2}{*}{$\begin{array}{l}\text { Interval } \\
\text { advanced } \\
(\mathrm{m})\end{array}$} & \multicolumn{2}{|c|}{ Depth CSF (m) } & \multirow[b]{2}{*}{$\begin{array}{l}\text { Length of core } \\
\text { recovered } \\
(\mathrm{m})\end{array}$} & \multirow[b]{2}{*}{$\begin{array}{l}\text { Recovery } \\
\text { (\%) }\end{array}$} \\
\hline & & & $\begin{array}{l}\text { Top of } \\
\text { cored } \\
\text { interval }\end{array}$ & $\begin{array}{l}\text { Bottom of } \\
\text { cored } \\
\text { interval }\end{array}$ & & $\begin{array}{l}\text { Top of } \\
\text { cored } \\
\text { interval }\end{array}$ & $\begin{array}{l}\text { Bottom of } \\
\text { cored } \\
\text { interval }\end{array}$ & & \\
\hline $36 \mathrm{H}$ & $17 \mathrm{Apr}$ & 2125 & 331.9 & 341.4 & 9.5 & 331.90 & 341.85 & 9.95 & 105 \\
\hline $37 x$ & $17 \mathrm{Apr}$ & 2245 & 341.4 & 351.1 & 9.7 & 341.40 & 350.10 & 8.66 & 90 \\
\hline $38 \mathrm{X}$ & $18 \mathrm{Apr}$ & 0000 & 351.1 & 360.7 & 9.6 & 351.10 & 359.20 & 8.06 & 84 \\
\hline $39 x$ & $18 \mathrm{Apr}$ & 0105 & 360.7 & 370.2 & 9.5 & 360.70 & 369.41 & 8.71 & 92 \\
\hline $40 x$ & $18 \mathrm{Apr}$ & 0245 & 370.2 & 379.7 & 9.5 & 370.20 & 376.65 & 6.45 & 68 \\
\hline $41 x$ & $18 \mathrm{Apr}$ & 0350 & 379.7 & 389.2 & 9.5 & 379.70 & 387.66 & 7.96 & 84 \\
\hline $42 x$ & $18 \mathrm{Apr}$ & 0525 & 389.2 & 398.8 & 9.6 & 389.20 & 396.33 & 7.13 & 74 \\
\hline $43 x$ & $18 \mathrm{Apr}$ & 0700 & 398.8 & 408.4 & 9.6 & 398.80 & 408.23 & 9.43 & 98 \\
\hline $44 X$ & $18 \mathrm{Apr}$ & 0915 & 408.4 & 418.1 & 9.7 & 408.40 & 417.81 & 9.41 & 97 \\
\hline \multirow[t]{2}{*}{$45 x$} & $18 \mathrm{Apr}$ & 1505 & 418.1 & 421.1 & 3.0 & 418.10 & 420.13 & 2.03 & 68 \\
\hline & & & \multicolumn{2}{|c|}{$\begin{array}{r}\text { Advanced total: } \\
\text { Total interval cored: }\end{array}$} & $\begin{array}{l}421.1 \\
421.1\end{array}$ & & & 422.08 & 100 \\
\hline \multicolumn{10}{|c|}{ 320-U1335B- } \\
\hline $1 \mathrm{H}$ & $18 \mathrm{Apr}$ & 2020 & 0.0 & 3.3 & 3.3 & 0.00 & 3.48 & 3.48 & 105 \\
\hline $2 \mathrm{H}$ & $18 \mathrm{Apr}$ & 2130 & 3.3 & 12.8 & 9.5 & 3.30 & 13.07 & 9.77 & 103 \\
\hline $3 \mathrm{H}$ & $18 \mathrm{Apr}$ & 2245 & 12.8 & 22.3 & 9.5 & 12.80 & 22.71 & 9.91 & 104 \\
\hline $4 \mathrm{H}$ & $18 \mathrm{Apr}$ & 2345 & 22.3 & 31.8 & 9.5 & 22.30 & 31.98 & 9.68 & 102 \\
\hline $5 \mathrm{H}$ & $19 \mathrm{Apr}$ & 0105 & 31.8 & 41.3 & 9.5 & 31.80 & 41.89 & 10.09 & 106 \\
\hline $6 \mathrm{H}$ & $19 \mathrm{Apr}$ & 0205 & 41.3 & 50.8 & 9.5 & 41.30 & 51.08 & 9.78 & 103 \\
\hline $7 \mathrm{H}$ & $19 \mathrm{Apr}$ & 0331 & 50.8 & 60.3 & 9.5 & 50.80 & 60.95 & 10.15 & 107 \\
\hline $8 \mathrm{H}$ & $19 \mathrm{Apr}$ & 0425 & 60.3 & 69.8 & 9.5 & 60.30 & 70.06 & 9.76 & 103 \\
\hline $9 \mathrm{H}$ & $19 \mathrm{Apr}$ & 0535 & 69.8 & 79.3 & 9.5 & 69.80 & 79.97 & 10.17 & 107 \\
\hline $10 \mathrm{H}$ & $19 \mathrm{Apr}$ & 0640 & 79.3 & 88.8 & 9.5 & 79.30 & 89.07 & 9.77 & 103 \\
\hline $11 \mathrm{H}$ & $19 \mathrm{Apr}$ & 0755 & 88.8 & 98.3 & 9.5 & 88.80 & 99.00 & 10.20 & 107 \\
\hline $12 \mathrm{H}$ & $19 \mathrm{Apr}$ & 0855 & 98.3 & 107.8 & 9.5 & 98.30 & 108.11 & 9.81 & 103 \\
\hline $13 \mathrm{H}$ & $19 \mathrm{Apr}$ & 0955 & 107.8 & 117.3 & 9.5 & 107.80 & 117.68 & 9.88 & 104 \\
\hline $14 \mathrm{H}$ & $19 \mathrm{Apr}$ & 1050 & 117.3 & 126.8 & 9.5 & 117.30 & 127.04 & 9.74 & 103 \\
\hline $15 \mathrm{H}$ & $19 \mathrm{Apr}$ & 1150 & 126.8 & 136.3 & 9.5 & 126.80 & 136.83 & 10.03 & 106 \\
\hline $16 \mathrm{H}$ & $19 \mathrm{Apr}$ & 1255 & 136.3 & 145.8 & 9.5 & 136.30 & 146.22 & 9.92 & 104 \\
\hline $17 \mathrm{H}$ & $19 \mathrm{Apr}$ & 1355 & 145.8 & 155.3 & 9.5 & 145.80 & 155.69 & 9.89 & 104 \\
\hline $18 \mathrm{H}$ & $19 \mathrm{Apr}$ & 1455 & 155.3 & 164.8 & 9.5 & 155.30 & 164.83 & 9.53 & 100 \\
\hline $19 \mathrm{H}$ & $19 \mathrm{Apr}$ & 1620 & 164.8 & 174.3 & 9.5 & 164.80 & 174.86 & 10.06 & 106 \\
\hline $20 \mathrm{H}$ & $19 \mathrm{Apr}$ & 1745 & 174.3 & 183.8 & 9.5 & 174.30 & 184.40 & 10.10 & 106 \\
\hline $21 \mathrm{H}$ & $19 \mathrm{Apr}$ & 1855 & 183.8 & 193.3 & 9.5 & 183.80 & 193.47 & 9.67 & 102 \\
\hline $22 \mathrm{H}$ & $19 \mathrm{Apr}$ & 1955 & 193.3 & 202.8 & 9.5 & 193.30 & 202.86 & 9.56 & 101 \\
\hline $23 \mathrm{H}$ & $19 \mathrm{Apr}$ & 2100 & 202.8 & 212.3 & 9.5 & 202.80 & 211.83 & 9.03 & 95 \\
\hline $24 \mathrm{H}$ & $19 \mathrm{Apr}$ & 2210 & 212.3 & 221.8 & 9.5 & 212.30 & 222.16 & 9.86 & 104 \\
\hline $25 \mathrm{H}$ & $19 \mathrm{Apr}$ & 2320 & 221.8 & 231.3 & 9.5 & 221.80 & 231.47 & 9.67 & 102 \\
\hline $26 \mathrm{H}$ & $20 \mathrm{Apr}$ & 0050 & 231.3 & 240.8 & 9.5 & 231.30 & 241.43 & 10.13 & 107 \\
\hline $27 \mathrm{H}$ & $20 \mathrm{Apr}$ & 0255 & 240.8 & 250.3 & 9.5 & 240.80 & 250.93 & 10.13 & 107 \\
\hline $28 \mathrm{H}$ & $20 \mathrm{Apr}$ & 0450 & 250.3 & 259.8 & 9.5 & 250.30 & 260.43 & 10.13 & 107 \\
\hline $29 \mathrm{H}$ & $20 \mathrm{Apr}$ & 0600 & 259.8 & 269.3 & 9.5 & 259.80 & 269.72 & 9.92 & 104 \\
\hline $30 \mathrm{H}$ & $20 \mathrm{Apr}$ & 0700 & 269.3 & 278.8 & 9.5 & 269.30 & 279.12 & 9.82 & 103 \\
\hline $31 \mathrm{H}$ & $20 \mathrm{Apr}$ & 0810 & 278.8 & 288.3 & 9.5 & 278.80 & 288.55 & 9.75 & 103 \\
\hline $32 \mathrm{H}$ & $20 \mathrm{Apr}$ & 0910 & 288.3 & 297.8 & 9.5 & 288.30 & 297.99 & 9.69 & 102 \\
\hline $33 \mathrm{H}$ & $20 \mathrm{Apr}$ & 1015 & 297.8 & 307.3 & 9.5 & 297.80 & 307.90 & 10.10 & 106 \\
\hline $34 \mathrm{H}$ & $20 \mathrm{Apr}$ & 1125 & 307.3 & 316.8 & 9.5 & 307.30 & 317.00 & 9.70 & 102 \\
\hline $35 \mathrm{H}$ & $20 \mathrm{Apr}$ & 1305 & 316.8 & 326.3 & 9.5 & 316.80 & 326.89 & 10.09 & 106 \\
\hline $36 \mathrm{H}$ & $20 \mathrm{Apr}$ & 1430 & 326.3 & 335.8 & 9.5 & 326.30 & 336.57 & 10.27 & 108 \\
\hline $37 \mathrm{H}$ & $20 \mathrm{Apr}$ & 1600 & 335.8 & 343.8 & 8.0 & 335.80 & 344.11 & 8.31 & 104 \\
\hline $38 \mathrm{H}$ & $20 \mathrm{Apr}$ & 1725 & 343.8 & 352.8 & 9.0 & 343.80 & 352.89 & 9.09 & 101 \\
\hline $39 \mathrm{H}$ & $20 \mathrm{Apr}$ & 1850 & 352.8 & 362.3 & 9.5 & 352.80 & 362.51 & 9.71 & 102 \\
\hline $40 \mathrm{H}$ & $20 \mathrm{Apr}$ & 2000 & 362.3 & 370.1 & 7.8 & 362.30 & 370.39 & 8.09 & 104 \\
\hline $41 \mathrm{H}$ & $20 \mathrm{Apr}$ & 2200 & 370.1 & 378.2 & 8.1 & 370.10 & 378.35 & 8.25 & 102 \\
\hline $42 x$ & $21 \mathrm{Apr}$ & 0010 & 378.2 & 386.2 & 8.0 & 378.20 & 386.67 & 8.47 & 106 \\
\hline $43 x$ & $21 \mathrm{Apr}$ & 0140 & 386.2 & 395.8 & 9.6 & 386.20 & 394.91 & 8.71 & 91 \\
\hline $44 X$ & $21 \mathrm{Apr}$ & 0345 & 395.8 & 405.4 & 9.6 & 395.80 & 404.75 & 8.95 & 93 \\
\hline $45 x$ & $21 \mathrm{Apr}$ & 0620 & 405.4 & 415.0 & 9.6 & 405.40 & 412.01 & 6.61 & 69 \\
\hline \multirow{3}{*}{$46 x$} & $21 \mathrm{Apr}$ & 1015 & 415.0 & 417.5 & 2.5 & 415.00 & 418.27 & 3.27 & 131 \\
\hline & & & \multirow{2}{*}{\multicolumn{2}{|c|}{$\begin{array}{l}\text { Advanced total: } \\
\text { Total interval cored: }\end{array}$}} & 417.5 & & & 428.70 & 103 \\
\hline & & & & & 417.5 & & & & \\
\hline
\end{tabular}

Notes: $\mathrm{DRF}=$ drilling depth below rig floor, $\mathrm{DSF}=$ drilling depth below seafloor, $\mathrm{CSF}=$ core depth below seafloor. $\mathrm{H}=\mathrm{APC}$ core, $\mathrm{X}=\mathrm{XCB}$ core Local time $=$ UTC $-10 \mathrm{~h}$. 
Table T2. Lithologic unit boundaries, Site U1335. (See table notes.)

\begin{tabular}{|c|c|c|c|c|}
\hline Unit & $\begin{array}{l}\text { Core, section, } \\
\text { interval }(\mathrm{cm})\end{array}$ & $\begin{array}{l}\text { Depth } \\
\text { CSF (m) }\end{array}$ & $\begin{array}{l}\text { Core, section, } \\
\text { interval }(\mathrm{cm})\end{array}$ & $\begin{array}{l}\text { Depth } \\
\operatorname{CSF}(m)\end{array}$ \\
\hline & 320-U1331A- & & 320-U1331B- & \\
\hline I & 7H-6, 44 & 64.34 & $8 \mathrm{H}-5,75$ & 67.05 \\
\hline II & $45 \mathrm{X}-\mathrm{CC}, 20^{*}$ & 420.13 & $46 \mathrm{X}-\mathrm{CC}, 8$ & 418.04 \\
\hline III & - & - & $46 \mathrm{X}-\mathrm{CC}, 46^{*}$ & 418.42 \\
\hline
\end{tabular}

Notes: Interval/depth are given for basal boundary of each unit. * = unit extends through at least given interval and depth, but boundary was not cored. $-=$ boundary not cored. 
Table T3. Positions of sharp contacts and thickness and textures of overlying nannofossil foraminifer ooze bed, Site U1335. (See table notes.)

\begin{tabular}{|c|c|c|c|c|c|c|c|c|}
\hline \multirow[b]{2}{*}{ Unit } & \multicolumn{2}{|c|}{ Contact position } & \multirow[b]{2}{*}{$\begin{array}{l}\text { Thickness } \\
\text { (cm) }\end{array}$} & \multirow[b]{2}{*}{ Texture } & \multicolumn{2}{|c|}{ Contact position } & \multirow[b]{2}{*}{$\begin{array}{l}\text { Thickness } \\
(\mathrm{cm})\end{array}$} & \multirow[b]{2}{*}{ Texture } \\
\hline & $\begin{array}{l}\text { Core, section, } \\
\text { interval }(\mathrm{cm})\end{array}$ & $\begin{array}{l}\text { Depth } \\
\text { CSF (m) }\end{array}$ & & & $\begin{array}{l}\text { Core, section, } \\
\text { interval }(\mathrm{cm})\end{array}$ & $\begin{array}{l}\text { Depth } \\
\text { CSF }(\mathrm{m})\end{array}$ & & \\
\hline I & $\begin{array}{c}320-\mathrm{U} 1335 \mathrm{~A}- \\
2 \mathrm{H}-1,126\end{array}$ & 10.16 & 2 & 1,2 & $\begin{array}{l}320-U 1335 B- \\
2 \mathrm{H}-6,55\end{array}$ & 11.35 & 5 & 1,2 \\
\hline \multirow[t]{50}{*}{ II } & $9 \mathrm{H}-2,103$ & 77.96 & 2 & 1,2 & $8 \mathrm{H}-6,133$ & 69.13 & 3 & 1,2 \\
\hline & $9 \mathrm{H}-6,55$ & 83.47 & 2 & 1,2 & $9 \mathrm{H}-6,112$ & 78.42 & 7 & 1,2 \\
\hline & $10 \mathrm{H}-4,57$ & 89.97 & 21 & 1,2 & $10 \mathrm{H}-2,93$ & 81.73 & 4 & 1,2 \\
\hline & $11 \mathrm{H}-3,50$ & 97.90 & 2 & 1,2 & $11 \mathrm{H}-4,38$ & 93.68 & 4 & $1,2^{\dagger}$ \\
\hline & $12 \mathrm{H}-6,135$ & 112.75 & 66 & $1,2,3,4$ & $12 \mathrm{H}-3,75$ & 102.05 & 2 & 1,2 \\
\hline & $13 \mathrm{H}-6,132$ & 122.27 & 5 & 1,2 & $13 \mathrm{H}-2,127$ & 110.57 & 7 & 1,2 \\
\hline & $14 \mathrm{H}-3,29$ & 126.19 & 9 & 1,2 & $15 \mathrm{H}-1,94$ & 127.74 & 11 & 1,2 \\
\hline & $15 \mathrm{H}-4,104$ & 137.44 & 4 & 1,2 & $15 \mathrm{H}-5,145$ & 134.25 & 5 & 1,2 \\
\hline & $16 \mathrm{H}-2,113$ & 144.54 & 22 & $1,2,5$ & $16 \mathrm{H}-7,32$ & 145.62 & 18 & 1,2 \\
\hline & $17 \mathrm{H}-2,92$ & 153.82 & 3 & 1,2 & $17 \mathrm{H}-2,13$ & 147.43 & 3 & 1,2 \\
\hline & $17 \mathrm{H}-6,84$ & 159.75 & 1 & 1,2 & $17 \mathrm{H}-4,136$ & 151.66 & 2 & 1,2 \\
\hline & $18 \mathrm{H}-4,117$ & 166.57 & 14 & $1,2,6$ & $17 \mathrm{H}-6,122$ & 154.52 & 4 & 1,2 \\
\hline & 19H-4, 39 & 175.29 & 15 & $1,2,6$ & $17 \mathrm{H}-\mathrm{CC}, 10$ & 155.54 & 6 & 1,2 \\
\hline & $20 \mathrm{H}-3,28$ & 183.18 & 12 & 1,2 & $19 \mathrm{H}-2,37$ & 166.67 & 2 & 1,2 \\
\hline & $21 \mathrm{H}-2,129$ & 192.19 & 67 & $1,2,3,4,5$ & $19 \mathrm{H}-6,39$ & 172.69 & 15 & 1,2 \\
\hline & $21 \mathrm{H}-5,135$ & 196.75 & 40 & $1,2,4$ & $20 \mathrm{H}-6,5$ & 181.85 & 15 & 1,2 \\
\hline & $22 \mathrm{H}-5,107$ & 205.97 & 17 & 1,2 & $21 \mathrm{H}-5,144$ & 191.24 & 49 & $1,2,3$ \\
\hline & $23 \mathrm{H}-1,130$ & 209.70 & 30 & 1,2 & $22 \mathrm{H}-1,125$ & 194.55 & 35 & 1,2 \\
\hline & $23 \mathrm{H}-3,141$ & 212.81 & 41 & $2,4^{*}$ & $22 \mathrm{H}-4,93$ & 198.73 & 10 & 1,2 \\
\hline & $24 \mathrm{H}-4,106$ & 223.46 & 3 & 1,2 & $22 \mathrm{H}-6,35$ & 201.15 & 6 & 1,2 \\
\hline & $24 \mathrm{H}-5,102$ & 224.92 & 2 & 1,2 & $23 \mathrm{H}-5,40$ & 209.02 & 28 & 1,2 \\
\hline & $25 \mathrm{H}-6,16$ & 235.06 & 22 & 1,2 & $24 \mathrm{H}-1,51$ & 212.81 & 4 & 1,2 \\
\hline & $25 \mathrm{H}-6,63$ & 235.53 & 6 & 1,2 & $24 \mathrm{H}-3,53$ & 215.83 & 7 & 1,2 \\
\hline & $26 \mathrm{H}-1,38$ & 237.28 & 2 & 1,2 & $25 \mathrm{H}-2,92$ & 224.22 & 7 & 1,2 \\
\hline & $27 \mathrm{H}-2,16$ & 248.06 & 53 & $1,2,4$ & $25 \mathrm{H}-4,12$ & 226.42 & 4 & 1,2 \\
\hline & $27 \mathrm{H}-4,131$ & 252.21 & 4 & 1,2 & $25 \mathrm{H}-6,126$ & 230.56 & 3 & 1,2 \\
\hline & $27 \mathrm{H}-4,144$ & 252.34 & 2 & 1,2 & $26 \mathrm{H}-2,85$ & 233.65 & 35 & 1,2 \\
\hline & $27 \mathrm{H}-6,24$ & 254.14 & 10 & 1,2 & $26 \mathrm{H}-5,42$ & 237.72 & 6 & 1,2 \\
\hline & $29 \mathrm{H}-1,35$ & 265.75 & 35 & 1 & $27 \mathrm{H}-2,107$ & 243.37 & 3 & 1,2 \\
\hline & $29 \mathrm{H}-3,102$ & 269.42 & 3 & 1 & $27 \mathrm{H}-5,76$ & 247.56 & 10 & 1,2 \\
\hline & $29 \mathrm{H}-4,115$ & 271.05 & 3 & 1 & $27 \mathrm{H}-6,68$ & 248.98 & 52 & 1,2 \\
\hline & $29 \mathrm{H}-5,119$ & 272.59 & 3 & 1 & $28 \mathrm{H}-1,120$ & 251.5 & 4 & 1,2 \\
\hline & $30 \mathrm{H}-1,22$ & 275.12 & 8 & 1 & $28 \mathrm{H}-1,135$ & 251.65 & 1 & 1,2 \\
\hline & $30 \mathrm{H}-2,147$ & 277.87 & 4 & 1 & $28 \mathrm{H}-3,42$ & 253.72 & 20 & 1,2 \\
\hline & $30 \mathrm{H}-6,8$ & 282.48 & 1 & 1 & $29 \mathrm{H}-1,51$ & 260.31 & 1 & 1,2 \\
\hline & $30 \mathrm{H}-6,113$ & 283.53 & 4 & $1^{\dagger}$ & $29 \mathrm{H}-5,13$ & 265.93 & 113 & 1,2 \\
\hline & $31 \mathrm{H}-3,49$ & 287.89 & 22 & 1 & $29 \mathrm{H}-\mathrm{CC}, 12$ & 269.55 & 1 & 1,2 \\
\hline & $31 \mathrm{H}-5,50$ & 290.90 & 22 & 1 & $30 \mathrm{H}-1,78$ & 270.08 & 1 & 1,2 \\
\hline & $31 \mathrm{H}-5,86$ & 291.26 & 1 & 1 & $30 \mathrm{H}-3,150$ & 273.8 & 30 & 1,2 \\
\hline & $32 \mathrm{H}-5,91$ & 300.81 & 162 & 1,2 & $31 \mathrm{H}-2,49$ & 280.79 & 2 & 1,2 \\
\hline & $33 \mathrm{H}-3,3$ & 306.43 & 2 & 1 & $31 \mathrm{H}-6,97$ & 287.27 & 43 & 1,2 \\
\hline & $35 \mathrm{H}-6,81$ & 330.71 & 3 & 1 & $33 \mathrm{H}-1,40$ & 298.2 & 40 & 1,2 \\
\hline & $36 \mathrm{H}-3,63$ & 335.53 & 3 & 1 & $33 \mathrm{H}-4,54$ & 302.4 & 44 & 1,2 \\
\hline & $36 \mathrm{H}-5,56$ & 338.46 & 12 & 1,2 & $34 \mathrm{H}-4,54$ & 312.34 & 32 & 1,2 \\
\hline & $37 X-6,44$ & 349.34 & 18 & 1,6 & $34 \mathrm{H}-5,115$ & 314.45 & 2 & 1,2 \\
\hline & $38 X-1,77$ & 351.87 & 3 & 1,2 & $35 \mathrm{H}-1,22$ & 317.02 & 0 & 1,2 \\
\hline & $39 X-1,95$ & 361.65 & 15 & $1,2,6$ & $36 \mathrm{H}-3,71$ & 330.11 & 176 & 1,2 \\
\hline & & & & & $38 \mathrm{H}-1,90$ & 344.7 & 4 & 1,2 \\
\hline & & & & & $39 \mathrm{H}-4,26$ & 357.56 & 18 & 1,2 \\
\hline & & & & & $39 \mathrm{H}-6,51$ & 360.81 & 6 & 1,2 \\
\hline
\end{tabular}

Notes: Textures: 1 = sharp basal boundary, 2 = normal grading, 3 = millimeter-scale angular fragments of basalt at base (rip-up clast?), $4=$ decreasing foraminifer content observed upward, $5=$ millimeter-scale pyritized foraminifers at base, $6=$ laminations in upper-middle part of bed. ${ }^{*}=$ thickness may be $>41 \mathrm{~cm}$, as the base of coarse layer is within interstitial water sampling interval, $\dagger=$ inclined basal boundary. 
Table T4. Calcareous nannofossil datums, Site U1335. (See table notes.)

\begin{tabular}{|c|c|c|c|c|c|c|c|}
\hline \multicolumn{2}{|c|}{ Core, section, interval $(\mathrm{cm})$} & \multirow[b]{2}{*}{ Marker species } & \multirow{2}{*}{$\begin{array}{c}\text { Age } \\
(\mathrm{Ma})\end{array}$} & \multicolumn{4}{|c|}{ Depth CSF (m) } \\
\hline Top & Bottom & & & Top & Bottom & Midpoint & \pm \\
\hline $\begin{array}{c}320-U 1335 \mathrm{~A}- \\
1 \mathrm{H}-1,40\end{array}$ & $\begin{array}{c}320-U 1335 \mathrm{~A}- \\
1 \mathrm{H}-3,100\end{array}$ & T Pseudoemiliania lacunosa & 0.44 & 0.40 & 4.00 & 2.20 & 1.80 \\
\hline \multirow[t]{2}{*}{$1 \mathrm{H}-5,90$} & $1 \mathrm{H}-\mathrm{CC}$ & T Calcidiscus macintyrei & 1.61 & 6.90 & 8.81 & 7.86 & 0.96 \\
\hline & & Pliocene/Pleistocene boundary & & & & & \\
\hline $1 \mathrm{H}-5,90$ & $1 \mathrm{H}-\mathrm{CC}$ & T Discoaster brouweri & 1.93 & 6.90 & 8.81 & 7.86 & 0.96 \\
\hline $2 \mathrm{H}-1,30$ & $2 \mathrm{H}-3,123$ & T Discoaster pentaradiatus & 2.39 & 9.20 & 13.13 & 11.17 & 1.97 \\
\hline $2 \mathrm{H}-1,30$ & $2 \mathrm{H}-3,123$ & T Discoaster surculus & 2.49 & 9.20 & 13.13 & 11.17 & 1.97 \\
\hline $2 \mathrm{H}-3,123$ & $2 \mathrm{H}-5,107$ & T Discoaster tamalis & 2.80 & 13.13 & 15.97 & 14.55 & 1.42 \\
\hline $2 \mathrm{H}-\mathrm{CC}$ & $3 \mathrm{H}-2,80$ & T Sphenolithus spp. & 3.54 & 18.85 & 20.70 & 19.78 & 0.92 \\
\hline $2 \mathrm{H}-\mathrm{CC}$ & $3 \mathrm{H}-2,80$ & T Reticulofenestra pseudoumbilicus & 3.70 & 18.85 & 20.70 & 19.78 & 0.92 \\
\hline $3 \mathrm{H}-5,18$ & $3 \mathrm{H}-6,88$ & T Ceratolithus acutus & 5.04 & 24.58 & 26.78 & 25.68 & 1.10 \\
\hline $3 \mathrm{H}-5,18$ & $3 \mathrm{H}-6,88$ & B Ceratolithus rugosus & 5.05 & 24.58 & 26.78 & 25.68 & 1.10 \\
\hline \multirow[t]{2}{*}{$3 \mathrm{H}-\mathrm{CC}$} & $4 \mathrm{H}-1,66$ & T Triquetrorhabdulus rugosus & 5.28 & 28.13 & 29.22 & 28.68 & 0.55 \\
\hline & & Miocene/Pliocene boundary & & & & & \\
\hline $3 \mathrm{H}-\mathrm{CC}$ & $4 \mathrm{H}-1,66$ & B Ceratolithus acutus & 5.35 & 28.13 & 29.22 & 28.68 & 0.55 \\
\hline $4 \mathrm{H}-1,66$ & $4 \mathrm{H}-2,66$ & T Discoaster quinqueramus & 5.58 & 29.22 & 30.37 & 29.80 & 0.58 \\
\hline $4 \mathrm{H}-5,37$ & $4 \mathrm{H}-6,66$ & Tc Nicklithus amplificus & 5.98 & 34.27 & 36.06 & 35.17 & 0.89 \\
\hline $5 \mathrm{H}-3,10$ & $5 \mathrm{H}-5,50$ & B Amaurolithus spp. & 7.36 & 40.50 & 43.90 & 42.20 & 1.70 \\
\hline $5 \mathrm{H}-\mathrm{CC}$ & $6 \mathrm{H}-1,60$ & B Discoaster berggrenii & 8.29 & 46.45 & 47.50 & 46.45 & 0.52 \\
\hline $7 \mathrm{H}-2,10$ & $7 \mathrm{H}-3,65$ & T Discoaster hamatus & 9.69 & 58.00 & 60.05 & 59.03 & 1.02 \\
\hline 7H-2, 10 & 7H-3, 65 & T Catinaster coalitus & 9.69 & 58.00 & 60.05 & 59.03 & 1.02 \\
\hline 7H-4, 82 & $7 \mathrm{H}-6,79$ & B Discoaster hamatus & 10.55 & 61.72 & 64.69 & 63.21 & 1.49 \\
\hline 7H- 4,82 & $7 \mathrm{H}-6,79$ & T Coccolithus miopelagicus & 10.60 & 61.72 & 64.69 & 63.21 & 1.49 \\
\hline $7 \mathrm{H}-4,82$ & $7 \mathrm{H}-6,79$ & B Catinaster coalitus & 10.89 & 61.72 & 64.69 & 63.21 & 1.49 \\
\hline $8 \mathrm{H}-4,90$ & $8 \mathrm{H}-6,90$ & Tc Discoaster kugleri & 11.58 & 71.30 & 74.30 & 72.80 & 1.50 \\
\hline $9 \mathrm{H}-1,70$ & $9 \mathrm{H}-3,70$ & Bc Discoaster kugleri & 11.86 & 76.10 & 79.10 & 77.60 & 1.50 \\
\hline $9 \mathrm{H}-7,70$ & $9 \mathrm{H}-\mathrm{CC}$ & T Coronocyclus nitescens & 12.12 & 84.70 & 85.02 & 84.86 & 0.16 \\
\hline 9H-CC & $10 \mathrm{H}-2,100$ & T Calcidiscus premacintyrei & 12.45 & 85.02 & 87.40 & 86.21 & 1.19 \\
\hline $12 \mathrm{H}-2,90$ & $12 \mathrm{H}-3, \mathrm{PAL}$ & Tc Cyclicargolithus floridanus & 13.33 & 106.30 & 108.39 & 107.35 & 1.05 \\
\hline $12 \mathrm{H}-4,90$ & $12 \mathrm{H}-6,90$ & T Sphenolithus heteromorphus & 13.53 & 109.30 & 112.30 & 110.80 & 1.50 \\
\hline $16 \mathrm{H}-\mathrm{CC}$ & $17 \mathrm{H}-2,70$ & B Discoaster petaliformis & 15.70 & 151.48 & 153.60 & 152.54 & 1.00 \\
\hline $17 \mathrm{H}-6,120$ & $17 \mathrm{H}-\mathrm{CC}$ & Tc Discoaster deflandrei & 15.66 & 161.10 & 161.19 & 160.65 & 0.55 \\
\hline $20 \mathrm{H}-2,70$ & $20 \mathrm{H}-4,70$ & Bc Sphenolithus heteromorphus & 17.71 & 182.10 & 185.10 & 183.60 & 1.50 \\
\hline $21 \mathrm{H}-2,80$ & $21 \mathrm{H}-4,80$ & Tc Sphenolithus belemnos & 17.95 & 191.70 & 194.70 & 193.20 & 1.50 \\
\hline $21 \mathrm{H}-4,80$ & $21 \mathrm{H}-6,80$ & T Triquetrorhabdulus carinatus & 18.28 & 194.70 & 197.70 & 196.20 & 1.50 \\
\hline $22 \mathrm{H}-\mathrm{CC}$ & $23 \mathrm{H}-2,90$ & B Sphenolithus belemnos & 19.03 & 208.65 & 210.80 & 209.73 & 1.08 \\
\hline $34 \mathrm{H}-3,149$ & $34 \mathrm{H}-\mathrm{CC}$ & Tc Triquetrorhabdulus carinatus & 22.09 & 316.00 & 323.00 & 319.50 & 3.50 \\
\hline \multirow[t]{2}{*}{$36 \mathrm{H}-\mathrm{CC}$} & $37 X-2,90$ & B Sphenolithus disbelemnos & 22.8 & 341.80 & 343.80 & 342.80 & 1.00 \\
\hline & & Oligocene/Miocene boundary & & & & & \\
\hline $37 X-6,50$ & $37 X-C C$ & T Sphenolithus delphix & 23.1 & 349.40 & 350.00 & 349.70 & 0.30 \\
\hline $37 X-C C$ & $38 X-2,90$ & B Sphenolithus delphix & 23.2 & 350.00 & 353.50 & 351.75 & 1.75 \\
\hline $43 X-2,81$ & $43 X-4,37$ & T Sphenolithus ciperoensis & 24.4 & 401.11 & 403.67 & 402.39 & 1.28 \\
\hline $42 \mathrm{X}-\mathrm{CC}$ & $43 X-2,81$ & X T. longus/T. carinatus & 24.7 & 396.30 & 401.10 & 398.70 & 2.40 \\
\hline $42 X-2,74$ & $42 X-4,114$ & Tc Cyclicargolithus abisectus & 24.7 & 391.44 & 394.84 & 393.14 & 1.70 \\
\hline
\end{tabular}

Notes: $\mathrm{PAL}=$ paleontology sample. $\mathrm{T}=$ top, $\mathrm{B}=$ bottom, $\mathrm{Tc}=$ top common, $\mathrm{BC}=$ bottom common, $\mathrm{X}=$ abundance crossover. 
Table T5. Radiolarian datums, Site U1335. (See table note.) (Continued on next page.)

\begin{tabular}{|c|c|c|c|c|c|c|c|c|c|c|c|c|c|}
\hline \multirow[b]{2}{*}{ Geologic age } & \multirow[b]{2}{*}{ Zone } & \multirow[b]{2}{*}{ Marker species } & \multirow{2}{*}{$\begin{array}{l}\text { Age } \\
\text { (Ma) }\end{array}$} & \multicolumn{2}{|c|}{ Core, section, interval $(\mathrm{cm})$} & \multicolumn{4}{|c|}{ Depth CSF (m) } & \multicolumn{4}{|c|}{ Depth CCSF-A (m) } \\
\hline & & & & Top & Bottom & Top & Bottom & Midpoint & \pm & Top & Bottom & Midpoint & \pm \\
\hline \multirow[t]{3}{*}{ Pleistocene } & RN14 & & & 320-U1335A- & 320-U1335A- & & & & & & & & \\
\hline & & T A. angulare & 1.214 & $1 \mathrm{H}-3,103-105$ & $1 \mathrm{H}-\mathrm{CC}$ & 4.04 & 8.82 & 6.43 & 2.39 & 4.18 & 8.96 & 6.57 & 2.39 \\
\hline & \multirow{3}{*}{ RN13 } & B T. trachelium & 1.757 & $1 \mathrm{H}-\mathrm{CC}$ & $2 \mathrm{H}-2,38-40$ & 8.82 & 10.79 & 9.81 & 0.98 & 8.96 & 11.80 & 10.38 & 1.42 \\
\hline \multirow{10}{*}{ Pliocene } & & B A. angulare & 1.972 & $1 \mathrm{H}-\mathrm{CC}$ & $2 \mathrm{H}-2,38-40$ & 8.82 & 10.79 & 9.81 & 0.98 & 8.96 & 11.80 & 10.38 & 1.42 \\
\hline & & T P. prismatium & 2.077 & $1 \mathrm{H}-\mathrm{CC}$ & $2 \mathrm{H}-2,38-40$ & 8.82 & 10.79 & 9.81 & 0.98 & 8.96 & 11.80 & 10.38 & 1.42 \\
\hline & RN12 & B C. davisiana & 2.889 & $2 \mathrm{H}-2,38-40$ & $2 \mathrm{H}-4,38-40$ & 10.79 & 13.79 & 12.29 & 1.50 & 11.80 & 14.80 & 13.30 & 1.50 \\
\hline & & T S. peregrina & 2.902 & $2 \mathrm{H}-4,38-40$ & $2 \mathrm{H}-\mathrm{CC}$ & 13.79 & 18.86 & 16.33 & 2.54 & 14.80 & 19.87 & 17.34 & 2.54 \\
\hline & RN11 & T S. pentas & 3.977 & $2 \mathrm{H}-\mathrm{CC}$ & $3 \mathrm{H}-2,105-107$ & 18.86 & 20.96 & 19.91 & 1.05 & 19.87 & 22.27 & 21.07 & 1.20 \\
\hline & & T P. doliolum & 4.032 & $2 \mathrm{H}-\mathrm{CC}$ & $3 \mathrm{H}-2,105-107$ & 18.86 & 20.96 & 19.91 & 1.05 & 19.87 & 22.27 & 21.07 & 1.20 \\
\hline & RN10 & $\mathrm{T} D$. penultima & 4.264 & $2 \mathrm{H}-\mathrm{CC}$ & $3 \mathrm{H}-2,105-107$ & 18.86 & 20.96 & 19.91 & 1.05 & 19.87 & 22.27 & 21.07 & 1.20 \\
\hline & \multirow{7}{*}{ RP9 } & B P. prismatium & 4.729 & $3 \mathrm{H}-4,105-107$ & $3 \mathrm{H}-\mathrm{CC}$ & 23.96 & 28.14 & 26.05 & 2.09 & 25.27 & 29.45 & 27.36 & 2.09 \\
\hline & & B N. renilla & 5.024 & $3 \mathrm{H}-4,105-107$ & $3 \mathrm{H}-\mathrm{CC}$ & 23.96 & 28.14 & 26.05 & 2.09 & 25.27 & 29.45 & 27.36 & 2.09 \\
\hline & & T S. omnitubus & 5.319 & $3 \mathrm{H}-4,105-107$ & $3 \mathrm{H}-\mathrm{CC}$ & 23.96 & 28.14 & 26.05 & 2.09 & 25.27 & 29.45 & 27.36 & 2.09 \\
\hline \multirow{14}{*}{ upper Miocene } & & T S. berminghami & 5.573 & $3 \mathrm{H}-\mathrm{CC}$ & $4 \mathrm{H}-2.100-102$ & 28.14 & 30.41 & 29.28 & 1.14 & 29.45 & 33.45 & 31.45 & 2.00 \\
\hline & & T S. johnsoni & 6.534 & $4 \mathrm{H}-4.100-102$ & $4 \mathrm{H}-\mathrm{CC}$ & 33.41 & 37.81 & 35.61 & 2.20 & 36.45 & 40.85 & 38.65 & 2.20 \\
\hline & & T C. саера & 6.599 & $4 \mathrm{H}-4.100-102$ & $4 \mathrm{H}-\mathrm{CC}$ & 33.41 & 37.81 & 35.61 & 2.20 & 36.45 & 40.85 & 38.65 & 2.20 \\
\hline & & S. delmontensis > S. peregrina & 7.75 & $4 \mathrm{H}-\mathrm{CC}$ & $5 \mathrm{H}-2,100-102$ & 37.81 & 39.91 & 38.86 & 1.05 & 40.85 & 45.08 & 42.97 & 2.11 \\
\hline & \multirow{5}{*}{ RN7 } & B S. peregrina & 7.84 & $5 \mathrm{H}-2,100-102$ & $5 \mathrm{H}-4,100-102$ & 39.91 & 42.91 & 41.41 & 1.50 & 45.08 & 48.08 & 46.58 & 1.50 \\
\hline & & B S. omnitubus & 8.25 & $5 \mathrm{H}-4,100-102$ & $5 \mathrm{H}-\mathrm{CC}$ & 42.91 & 46.46 & 44.69 & 1.78 & 48.08 & 51.63 & 49.86 & 1.78 \\
\hline & & T D. hughesi & 8.392 & $5 \mathrm{H}-4,100-102$ & $5 \mathrm{H}-\mathrm{CC}$ & 42.91 & 46.46 & 44.69 & 1.78 & 48.08 & 51.63 & 49.86 & 1.78 \\
\hline & & T B. miralestensis & 8.587 & $6 \mathrm{H}-2,105-107$ & $6 \mathrm{H}-4,105-107$ & 49.46 & 52.46 & 50.96 & 1.50 & 55.45 & 58.45 & 56.95 & 1.50 \\
\hline & & T D. petterssoni & 8.63 & $6 \mathrm{H}-2,105-107$ & $6 \mathrm{H}-4,105-107$ & 49.46 & 52.46 & 50.96 & 1.50 & 55.45 & 58.45 & 56.95 & 1.50 \\
\hline & \multirow{7}{*}{ RN6 } & D. petterssoni $>D$. hughesi & 8.76 & $6 \mathrm{H}-4,105-107$ & $6 \mathrm{H}-\mathrm{CC}$ & 52.46 & 56.46 & 54.46 & 2.00 & 58.45 & 62.45 & 60.45 & 2.00 \\
\hline & & B S. berminghami & 8.76 & $6 \mathrm{H}-\mathrm{CC}$ & 7H-2, 102-104 & 56.46 & 58.93 & 57.70 & 1.24 & 62.45 & 66.02 & 64.24 & 1.78 \\
\hline & & TS. wolffii & 8.95 & $6 \mathrm{H}-\mathrm{CC}$ & 7H-2, 102-104 & 56.46 & 58.93 & 57.70 & 1.24 & 62.45 & 66.02 & 64.24 & 1.78 \\
\hline & & B D. hughesi & 8.99 & $6 \mathrm{H}-\mathrm{CC}$ & 7H-2, 102-104 & 56.46 & 58.93 & 57.70 & 1.24 & 62.45 & 66.02 & 64.24 & 1.78 \\
\hline & & T C. japonica & 10.31 & 7H-2, 102-104 & $7 \mathrm{H}-4,102-104$ & 58.93 & 61.93 & 60.43 & 1.50 & 66.02 & 69.02 & 67.52 & 1.50 \\
\hline \multirow{16}{*}{ middle Miocene } & & T C. cristata & 10.88 & 7H-4, 102-104 & 7H-CC & 61.93 & 66.25 & 64.09 & 2.16 & 69.02 & 73.34 & 71.18 & 2.16 \\
\hline & & T C. cornuta & 11.86 & $9 \mathrm{H}-4,105-107$ & $9 \mathrm{H}-\mathrm{CC}$ & 80.96 & 85.03 & 83.00 & 2.04 & 91.05 & 95.12 & 93.09 & 2.04 \\
\hline & \multirow{8}{*}{ RN5 } & B D. petterssoni & 12.11 & $10 \mathrm{H}-2,105-107$ & $10 \mathrm{H}-4,105-107$ & 87.46 & 90.46 & 88.96 & 1.50 & 98.51 & 101.51 & 100.01 & 1.50 \\
\hline & & B C. japonica & 12.41 & $10 \mathrm{H}-\mathrm{CC}$ & $11 \mathrm{H}-2,104-106$ & 94.95 & 96.95 & 95.95 & 1.00 & 106.00 & 109.81 & 107.91 & 1.91 \\
\hline & & B L. neotera & 12.95 & $10 \mathrm{H}-\mathrm{CC}$ & $11 \mathrm{H}-2,104-106$ & 94.95 & 96.95 & 95.95 & 1.00 & 106.00 & 109.81 & 107.91 & 1.91 \\
\hline & & TS. armata & 13.5 & $12 \mathrm{H}-4,104-106$ & $12 \mathrm{H}-\mathrm{CC}$ & 109.45 & 113.85 & 111.65 & 2.20 & 122.31 & 126.71 & 124.51 & 2.20 \\
\hline & & T A. octopylus & 13.88 & $12 \mathrm{H}-4,104-106$ & $12 \mathrm{H}-\mathrm{CC}$ & 109.45 & 113.85 & 111.65 & 2.20 & 122.31 & 126.71 & 124.51 & 2.20 \\
\hline & & T C. costata & 14.229 & $13-4,104-106$ & $13 \mathrm{H}-\mathrm{CC}$ & 118.95 & 123.40 & 121.18 & 2.23 & 132.19 & 136.64 & 134.42 & 2.23 \\
\hline & & T D. dentata & 14.666 & $16 \mathrm{H}-3,149-150$ & $16 \mathrm{H}-4,115-117$ & 146.39 & 147.56 & 146.98 & 0.59 & 162.74 & 163.91 & 163.33 & 0.59 \\
\hline & & T L. stauropora & 14.826 & $16 \mathrm{H}-3,149-150$ & $16 \mathrm{H}-4,115-117$ & 146.39 & 147.56 & 146.98 & 0.59 & 162.74 & 163.91 & 163.33 & 0.59 \\
\hline & \multirow{6}{*}{ RN4 } & D. dentata $>D$. alata & 14.78 & $16 \mathrm{H}-\mathrm{CC}$ & $17 \mathrm{H}-2,104-106$ & 151.49 & 153.95 & 152.72 & 1.23 & 167.84 & 173.95 & 170.90 & 3.05 \\
\hline & & B D. alata & 15.08 & $17 \mathrm{H}-2,104-106$ & $17 \mathrm{H}-3,149-150$ & 153.95 & 155.89 & 154.92 & 0.97 & 173.95 & 175.89 & 174.92 & 0.97 \\
\hline & & B L. parkerae & 15.03 & $17 \mathrm{H}-2,104-106$ & $17 \mathrm{H}-3,149-150$ & 153.95 & 155.89 & 154.92 & 0.97 & 173.95 & 175.89 & 174.92 & 0.97 \\
\hline & & T C. cingulata & 15.13 & $18 \mathrm{H}-3,149-150$ & $18 \mathrm{H}-4,105-107$ & 165.39 & 166.46 & 165.93 & 0.54 & 185.86 & 186.93 & 186.40 & 0.54 \\
\hline & & T L. elongata & 15.15 & $18 \mathrm{H}-3,149-150$ & $18 \mathrm{H}-4,105-107$ & 165.39 & 166.46 & 165.93 & 0.54 & 185.86 & 186.93 & 186.40 & 0.54 \\
\hline & & B L. renzae & 16.77 & $18 \mathrm{H}-\mathrm{CC}$ & $19 \mathrm{H}-2,105-107$ & 169.73 & 172.96 & 171.35 & 1.62 & 190.20 & 194.27 & 192.24 & 2.04 \\
\hline \multirow{4}{*}{ lower Miocene } & & B C. costata & 17.49 & $19 \mathrm{H}-4,105-107$ & $19 \mathrm{H}-\mathrm{CC}$ & 175.96 & 180.42 & 178.19 & 2.23 & 197.27 & 201.73 & 199.50 & 2.23 \\
\hline & $\mathrm{RN3}$ & B D. dentata & 17.72 & $20 \mathrm{H}-4,104-106$ & $20 \mathrm{H}-\mathrm{CC}$ & 185.45 & 189.88 & 187.67 & 2.22 & 208.18 & 212.61 & 210.40 & 2.22 \\
\hline & RN3 & B L. stauropora & 17.72 & $20 \mathrm{H}-\mathrm{CC}$ & $21 \mathrm{H}-1,105-107$ & 189.88 & 190.46 & 190.17 & 0.29 & 212.61 & 214.58 & 213.60 & 0.99 \\
\hline & & B S. wolffii & 18.57 & $23 \mathrm{H}-3,149-150$ & $23 \mathrm{H}-4,105-107$ & 212.89 & 213.96 & 213.43 & 0.54 & 241.31 & 242.38 & 241.85 & 0.53 \\
\hline
\end{tabular}


Table T5 (continued).

\begin{tabular}{|c|c|c|c|c|c|c|c|c|c|c|c|c|c|}
\hline \multirow[b]{2}{*}{ Geologic age } & \multirow[b]{2}{*}{ Zone } & \multirow[b]{2}{*}{ Marker species } & \multirow{2}{*}{$\begin{array}{l}\text { Age } \\
(\mathrm{Ma})\end{array}$} & \multicolumn{2}{|c|}{ Core, section, interval $(\mathrm{cm})$} & \multicolumn{4}{|c|}{ Depth CSF (m) } & \multicolumn{4}{|c|}{ Depth CCSF-A (m) } \\
\hline & & & & Top & Bottom & Top & Bottom & Midpoint & \pm & Top & Bottom & Midpoint & \pm \\
\hline \multirow{15}{*}{ lower Miocene } & \multirow{6}{*}{ RN2 } & B D. forcipata & 18.61 & $24 \mathrm{H}-\mathrm{CC}$ & $25 \mathrm{H}-2,104-106$ & 227.85 & 229.96 & 228.91 & 1.06 & 259.48 & 262.73 & 261.11 & 1.63 \\
\hline & & T D. simplex & 18.69 & $24 \mathrm{H}-\mathrm{CC}$ & $25 \mathrm{H}-2,104-106$ & 227.85 & 229.96 & 228.91 & 1.06 & 259.48 & 262.73 & 261.11 & 1.63 \\
\hline & & T D. praeforcipata & 19.77 & $26 \mathrm{H}-\mathrm{CC}$ & $27 \mathrm{H}-2,100-102$ & 246.79 & 248.91 & 247.85 & 1.06 & 281.43 & 285.85 & 283.64 & 2.21 \\
\hline & & B D. simplex & 20.34 & $28 \mathrm{H}-4,105-107$ & $28 \mathrm{H}-\mathrm{CC}$ & 261.46 & 265.97 & 263.72 & 2.26 & 299.24 & 303.75 & 301.50 & 2.25 \\
\hline & & B S. delmontensis & 20.68 & $29 \mathrm{H}-4,105-107$ & $29 \mathrm{H}-\mathrm{CC}$ & 261.46 & 265.97 & 263.72 & 2.26 & 300.95 & 305.46 & 303.21 & 2.26 \\
\hline & & T L. pegetrum & 20.89 & $30 \mathrm{H}-5,104-106$ & $30 \mathrm{H}-\mathrm{CC}$ & 281.95 & 284.78 & 283.37 & 1.41 & 322.51 & 325.34 & 323.93 & 1.41 \\
\hline & & T T. annosa & 21.38 & $31 \mathrm{H}-3,149-150$ & $31 \mathrm{H}-4,105-107$ & 288.89 & 289.96 & 289.43 & 0.53 & 331.52 & 332.59 & 332.06 & 0.53 \\
\hline & \multirow{4}{*}{ RN1 } & B C. virginis & 21.39 & $31 \mathrm{H}-3,149-150$ & $31 \mathrm{H}-4,105-107$ & 288.89 & 289.96 & 289.43 & 0.53 & 331.52 & 332.59 & 332.06 & 0.53 \\
\hline & & $\mathrm{T}$ E. mitodes & 21.95 & $33 \mathrm{H}-4,105-107$ & $33 \mathrm{H}-\mathrm{CC}$ & 308.96 & 313.49 & 311.23 & 2.27 & 354.70 & 359.23 & 356.97 & 2.27 \\
\hline & & B C. serrata & 22.04 & $34 \mathrm{H}-2,105-107$ & $34 \mathrm{H}-3,149-150$ & 314.96 & 315.99 & 315.48 & 0.52 & 363.38 & 364.41 & 363.90 & 0.52 \\
\hline & & B C. cornuta & 22.26 & $36 \mathrm{H}-\mathrm{CC}$ & $37 X-2,104-106$ & 341.81 & 343.95 & 342.88 & 1.07 & 393.81 & 395.95 & 394.88 & 1.07 \\
\hline & & B C. tetrapera & 22.35 & $36 \mathrm{H}-\mathrm{CC}$ & $37 X-2,104-106$ & 341.81 & 343.95 & 342.88 & 1.07 & 393.81 & 395.95 & 394.88 & 1.07 \\
\hline & \multirow{7}{*}{ RP22 } & T A. gracilis & 22.62 & $38 \mathrm{H}-3,149-150$ & $38 \mathrm{H}-4,104-106$ & 355.59 & 356.65 & 356.12 & 0.53 & 407.59 & 408.65 & 408.12 & 0.53 \\
\hline & & B E. diaphanes & 22.95 & $39 X-3,149-150$ & 39X-CC & 365.19 & 396.37 & 380.78 & 15.59 & 417.19 & 448.37 & 432.78 & 15.59 \\
\hline & & T D. cyclacantha & 22.98 & $38 \mathrm{H}-3,149-150$ & $38 \mathrm{H}-4,104-106$ & 355.59 & 356.65 & 356.12 & 0.53 & 407.59 & 408.65 & 408.12 & 0.53 \\
\hline \multirow{9}{*}{ upper Oligocene } & & B D. cyclacantha & 23.29 & $39 X-3,149-150$ & $39 X-C C$ & 365.19 & 396.37 & 380.78 & 15.59 & 417.19 & 448.37 & 432.78 & 15.59 \\
\hline & & T D. papilio & 23.31 & 39X-CC & $40 X-2,104-106$ & 369.37 & 372.75 & 371.06 & 1.69 & 421.37 & 424.75 & 423.06 & 1.69 \\
\hline & & T L. longicornuta & 24.12 & $41 X-4,104-106$ & $41 \mathrm{X}-\mathrm{CC}$ & 385.25 & 387.62 & 386.44 & 1.19 & 437.25 & 439.62 & 438.44 & 1.19 \\
\hline & & T L. apodora & 24.5 & $41 \mathrm{X}-\mathrm{CC}$ & $42 X-2,104-106$ & 387.62 & 391.75 & 389.69 & 2.06 & 439.62 & 443.75 & 441.69 & 2.06 \\
\hline & & B L. elongata & 25.05 & $42 X-4,104-106$ & $42 \mathrm{X}-\mathrm{CC}$ & 394.75 & 396.29 & 395.52 & 0.77 & 446.75 & 448.29 & 447.52 & 0.77 \\
\hline & \multirow{4}{*}{ RP21 } & B A. octopylus & 25.09 & $42 X-4,104-106$ & $42 \mathrm{X}-\mathrm{CC}$ & 394.75 & 396.29 & 395.52 & 0.77 & 446.75 & 448.29 & 447.52 & 0.77 \\
\hline & & B C. robusta & 25.27 & $44 X-2,105-107$ & $44 X-4,105-107$ & 410.96 & 413.96 & 412.46 & 1.50 & 462.96 & 465.96 & 464.46 & 1.50 \\
\hline & & B L. longicornuta & 25.29 & $44 X-2,105-107$ & $44 X-4,105-107$ & 410.96 & 413.96 & 412.46 & 1.50 & 462.96 & 465.96 & 464.46 & 1.50 \\
\hline & & B L. apodora & 25.55 & $44 X-2,105-107$ & $44 X-4,105-107$ & 410.96 & 413.96 & 412.46 & 1.50 & 462.96 & 465.96 & 464.46 & 1.50 \\
\hline
\end{tabular}

Note: $\mathrm{T}=$ top, $\mathrm{B}=$ bottom.

Table T6. Preservation and relative abundance of radiolarians, Hole U1335A. This table is available in an oversized format. 
Table T7. Preservation and relative abundance of radiolarians, Hole U1335B. (See table notes.)

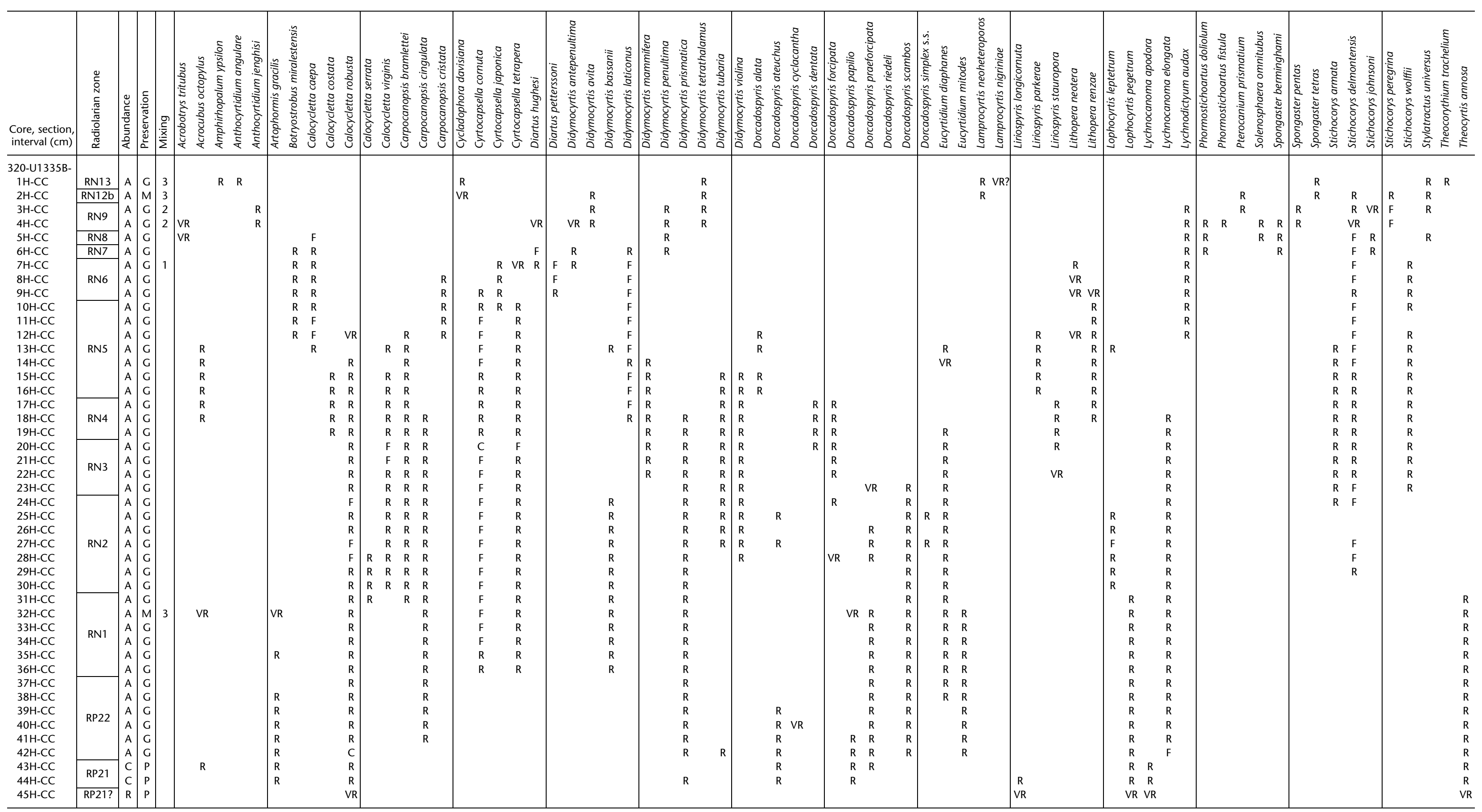

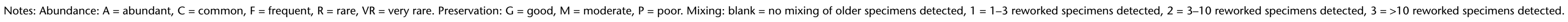


Table T8. Planktonic foraminifer datums, Site U1335. (See table note.) (Continued on next page.)

\begin{tabular}{|c|c|c|c|c|c|c|c|}
\hline \multicolumn{2}{|c|}{ Core, section, interval $(\mathrm{cm})$} & \multirow[b]{2}{*}{ Marker species } & \multirow{2}{*}{$\begin{array}{l}\text { Age } \\
(\mathrm{Ma})\end{array}$} & \multicolumn{4}{|c|}{ Depth CSF (m) } \\
\hline Top & Bottom & & & Top & Bottom & Midpoint & \pm \\
\hline 320-U1335A- & 320-U1335A- & Pliocene/Pleistocene boundary & & & & & \\
\hline $1 \mathrm{H}-\mathrm{CC}$ & $2 \mathrm{H}-2,104-106$ & T Globigerinoides fistulosus & 1.77 & 8.81 & 11.44 & 10.13 & 1.32 \\
\hline $1 \mathrm{H}-5,42-44$ & $1 \mathrm{H}-\mathrm{CC}$ & B Globorotalia (Truncorotalia) truncatulinoides & 1.92 & 6.42 & 8.81 & 7.62 & 1.20 \\
\hline $1 \mathrm{H}-\mathrm{CC}$ & $2 \mathrm{H}-2,104-106$ & T Globigerinoides extremus & 1.98 & 8.81 & 11.44 & 10.13 & 1.32 \\
\hline $1 \mathrm{H}-\mathrm{CC}$ & $2 \mathrm{H}-2,104-106$ & T Globorotalia pseudomiocenica & 2.30 & 8.81 & 11.44 & 10.13 & 1.32 \\
\hline $2 \mathrm{H}-2,104-106$ & $2 \mathrm{H}-4,104-106$ & T Globoturborotalita woodi & 2.30 & 11.44 & 14.44 & 12.94 & 1.50 \\
\hline $3 \mathrm{H}-2,38-40$ & $3 \mathrm{H}-4,38-40$ & T Globorotalia (Menardella) multicamerata & 2.98 & 20.28 & 23.28 & 21.78 & 1.50 \\
\hline $4 \mathrm{H}-5,120-1212$ & $5 \mathrm{H}-\mathrm{CC}$ & T Dentoglobigerina altispira & 3.47 & 35.10 & 46.45 & 40.78 & 5.68 \\
\hline $2 \mathrm{H}-2,104-106$ & $2 \mathrm{H}-4,104-106$ & T Sphaeroidinellopsis seminulina & 3.59 & 11.44 & 14.44 & 12.94 & 1.50 \\
\hline $2 \mathrm{H}-4,104-106$ & $2 \mathrm{H}-\mathrm{CC}$ & B Globorotalia (Menardella) exilis & 4.45 & 14.44 & 18.85 & 16.65 & 2.21 \\
\hline \multirow[t]{2}{*}{$3 \mathrm{H}-4,38-40$} & $3 \mathrm{H}-\mathrm{CC}$ & B Sphaeroidinella dehiscens s.I. & 5.54 & 23.28 & 28.13 & 25.71 & 2.42 \\
\hline & & Miocene/Pliocene boundary & & & & & \\
\hline $3 \mathrm{H}-\mathrm{CC}$ & $4 \mathrm{H}-3,100-102$ & B Globorotalia tumida & 5.57 & 28.13 & 31.90 & 30.02 & 1.89 \\
\hline $4 \mathrm{H}-\mathrm{CC}$ & $5 \mathrm{H}-2,80-82$ & B Globorotalia (Hirsutella) margaritae & 6.08 & 37.80 & 39.70 & 38.75 & 0.95 \\
\hline $6 \mathrm{H}-2,38-40$ & $6 \mathrm{H}-4,38-40$ & B Globorotalia plesiotumida & 8.58 & 46.45 & 51.78 & 49.12 & 2.67 \\
\hline $7 \mathrm{H}-6,95-97$ & 7H-CC & T Paragloborotalia mayeri & 10.46 & 64.85 & 66.24 & 65.55 & 0.69 \\
\hline $8 \mathrm{H}-\mathrm{CC}$ & $9 \mathrm{H}-2,38-40$ & B Globoturborotalita decoraperta & 11.49 & 75.86 & 77.28 & 76.57 & 0.71 \\
\hline $9 \mathrm{H}-2,38-40$ & $9 \mathrm{H}-4,38-40$ & T Globorotalia (Fohsella) fohsi s.I. & 11.79 & 77.28 & 80.28 & 78.78 & 1.50 \\
\hline $11 \mathrm{H}-\mathrm{CC}$ & $12-2 \mathrm{H}, 38-40$ & B Globorotalia (Fohsella) fohsi robusta & 13.13 & 104.16 & 105.78 & 104.97 & 0.81 \\
\hline $12-2 \mathrm{H}, 38-40$ & $12 \mathrm{H}-\mathrm{CC}$ & B Globorotalia (Fohsella) fohsi s.I. & 13.41 & 105.78 & 113.84 & 109.81 & 4.03 \\
\hline $12 \mathrm{H}-\mathrm{CC}$ & $13 \mathrm{H}-3,149-150$ & B Globorotalia (Fohsella) "praefohsi" & 13.77 & 113.84 & 117.89 & 115.87 & 2.03 \\
\hline $13 \mathrm{H}-4,38-40$ & $13 \mathrm{H}-\mathrm{CC}$ & T Globorotalia (Fohsella) peripheroronda & 13.80 & 118.28 & 123.39 & 120.84 & 2.56 \\
\hline $13 \mathrm{H}-3,149-150$ & $13 \mathrm{H}-4,38-40$ & T Clavatorella bermudezi & 13.82 & 117.89 & 118.28 & 118.09 & 0.20 \\
\hline $14 \mathrm{H}-2,38-40$ & $14 \mathrm{H}-4,38-40$ & B Clavatorella bermudezi & 14.89 & 124.78 & 127.78 & 126.28 & 1.50 \\
\hline $14 \mathrm{H}-2,38-41$ & $14 \mathrm{H}-4,38-41$ & B Globorotalia (Fohsella) peripheroacuta & 14.24 & 124.78 & 127.78 & 126.28 & 1.50 \\
\hline $16 \mathrm{H}-\mathrm{CC}$ & $17 \mathrm{H}-3,149-150$ & B Globorotalia (Menardella) archeomenardii & 16.26 & 155.89 & 161.19 & 158.54 & 2.65 \\
\hline $18 \mathrm{H}-\mathrm{CC}$ & $19 \mathrm{H}-2,38-40$ & B Praeorbulina sicana & 16.97 & 169.72 & 172.28 & 171.00 & 1.28 \\
\hline $19 \mathrm{H}-\mathrm{CC}$ & $20 \mathrm{H}-\mathrm{CC}$ & T Globoquadrina binaiensis & 19.09 & 180.41 & 189.97 & 185.19 & 4.78 \\
\hline $28 \mathrm{H}-4,38-40$ & $28 \mathrm{H}-\mathrm{CC}$ & T Paragloborotalia kugleri & 21.12 & 260.78 & 265.96 & 263.37 & 2.59 \\
\hline $28 \mathrm{H}-4,38-40$ & $28 \mathrm{H}-\mathrm{CC}$ & T Paragloborotalia pseudokugleri & 21.31 & 260.78 & 265.96 & 263.37 & 2.59 \\
\hline \multirow[t]{2}{*}{$37 X-2,48-50$} & $37 X-4,136-138$ & B Globoquadrina dehiscens & 22.44 & 343.38 & 347.26 & 345.32 & 1.94 \\
\hline & & Oligocene/Miocene boundary & & & & & \\
\hline $37 X-4,136-138$ & $37 X-C C$ & B Paragloborotalia kugleri & 23.00 & 347.26 & 350.01 & 348.64 & 1.38 \\
\hline \multirow[t]{2}{*}{ 320-U1335B- } & 320-U1335B- & & & & & & \\
\hline & & Pliocene/Pleistocene boundary & & & & & \\
\hline $1 \mathrm{H}-\mathrm{CC}$ & $2 \mathrm{H}-\mathrm{CC}$ & B Globorotalia (Truncorotalia) truncatulinoides & 1.92 & 3.43 & 13.02 & 8.23 & 4.80 \\
\hline $1 \mathrm{H}-\mathrm{CC}$ & $2 \mathrm{H}-\mathrm{CC}$ & T Globigerinoides extremus & 1.98 & 3.43 & 13.02 & 8.23 & 4.80 \\
\hline $1 \mathrm{H}-\mathrm{CC}$ & $2 \mathrm{H}-\mathrm{CC}$ & T Globorotalia pseudomiocenica & 2.30 & 3.43 & 13.02 & 8.23 & 4.80 \\
\hline $4 \mathrm{H}-\mathrm{CC}$ & $5 \mathrm{H}-\mathrm{CC}$ & T Dentoglobigerina altispira & 3.47 & 31.93 & 41.86 & 36.90 & 4.96 \\
\hline $2 \mathrm{H}-\mathrm{CC}$ & $3 \mathrm{H}-\mathrm{CC}$ & T Sphaeroidinellopsis seminulina & 3.59 & 13.02 & 22.66 & 17.84 & 4.82 \\
\hline \multirow[t]{2}{*}{$2 \mathrm{H}-\mathrm{CC}$} & $3 \mathrm{H}-\mathrm{CC}$ & B Sphaeroidinella dehiscens s.l. & 5.53 & 13.02 & 22.66 & 17.84 & 4.82 \\
\hline & & Miocene/Pliocene boundary & & & & & \\
\hline $3 \mathrm{H}-\mathrm{CC}$ & $4 \mathrm{H}-\mathrm{CC}$ & B Globorotalia tumida & 5.57 & 22.26 & 31.93 & 27.10 & 4.83 \\
\hline $6 \mathrm{H}-\mathrm{CC}$ & 7H-CC & B Globorotalia plesiotumida & 8.58 & 51.05 & 60.92 & 55.99 & 4.94 \\
\hline $\mathrm{7H}-\mathrm{CC}$ & $8 \mathrm{H}-\mathrm{CC}$ & T Globorotalia (Menardella) praemenardii & 10.09 & 60.92 & 70.02 & 65.47 & 4.55 \\
\hline 7H-CC & $8 \mathrm{H}-\mathrm{CC}$ & T Paragloborotalia mayeri & 10.46 & 60.92 & 70.02 & 65.47 & 4.55 \\
\hline $\mathrm{7H}-\mathrm{CC}$ & $8 \mathrm{H}-\mathrm{CC}$ & B Globoturborotalita decoraperta & 11.49 & 60.92 & 70.02 & 65.47 & 4.55 \\
\hline $8 \mathrm{H}-\mathrm{CC}$ & 9H-CC & T Globorotalia (Fohsella) fohsi s.I. & 11.79 & 70.02 & 79.49 & 74.76 & 4.74 \\
\hline $11 \mathrm{H}-\mathrm{CC}$ & $12 \mathrm{H}-\mathrm{CC}$ & B Globorotalia (Fohsella) fohsi robusta & 13.13 & 98.97 & 108.08 & 103.53 & 4.56 \\
\hline $11 \mathrm{H}-\mathrm{CC}$ & $12 \mathrm{H}-\mathrm{CC}$ & B Globorotalia (Fohsella) fohsi s.l. & 13.41 & 98.97 & 108.08 & 103.53 & 4.56 \\
\hline $12 \mathrm{H}-\mathrm{CC}$ & $13 \mathrm{H}-\mathrm{CC}$ & T Globorotalia praescitula & 13.73 & 108.08 & 117.65 & 112.87 & 4.79 \\
\hline $12 \mathrm{H}-\mathrm{CC}$ & $13 \mathrm{H}-\mathrm{CC}$ & B Globorotalia (Fohsella) "praefohsi" & 13.77 & 108.08 & 117.65 & 112.87 & 4.79 \\
\hline $12 \mathrm{H}-\mathrm{CC}$ & $13 \mathrm{H}-\mathrm{CC}$ & T Globorotalia (Fohsella) peripheroronda & 13.80 & 108.08 & 117.65 & 112.87 & 4.79 \\
\hline $17 \mathrm{H}-\mathrm{CC}$ & $18 \mathrm{H}-\mathrm{CC}$ & B Globorotalia (Menardella) archeomenardii & 16.26 & 155.64 & 164.78 & 160.21 & 4.57 \\
\hline $18 \mathrm{H}-\mathrm{CC}$ & $19 \mathrm{H}-\mathrm{CC}$ & B Praeorbulina sicana & 16.97 & 164.78 & 174.81 & 169.80 & 5.02 \\
\hline $20 \mathrm{H}-\mathrm{CC}$ & $21 \mathrm{H}-\mathrm{CC}$ & T Catapsydrax dissimilis & 17.54 & 184.35 & 193.42 & 188.89 & 4.53 \\
\hline $20 \mathrm{H}-\mathrm{CC}$ & $21 \mathrm{H}-\mathrm{CC}$ & T Globoquadrina binaiensis & 19.09 & 184.35 & 193.42 & 188.89 & 4.53 \\
\hline $30 \mathrm{H}-\mathrm{CC}$ & $29 \mathrm{H}-\mathrm{CC}$ & T Paragloborotalia kugleri & 21.12 & 269.69 & 279.09 & 274.39 & 4.70 \\
\hline $30 \mathrm{H}-\mathrm{CC}$ & $29 \mathrm{H}-\mathrm{CC}$ & T Paragloborotalia pseudokugleri & 21.31 & 269.69 & 279.09 & 274.39 & 4.70 \\
\hline $30 \mathrm{H}-\mathrm{CC}$ & $31 \mathrm{H}-\mathrm{CC}$ & B Globoquadrina dehiscens & 22.44 & 279.09 & 288.52 & 283.81 & 4.71 \\
\hline
\end{tabular}


Table T8 (continued).

\begin{tabular}{|c|c|c|c|c|c|c|c|}
\hline \multicolumn{2}{|c|}{ Core, section, interval $(\mathrm{cm})$} & \multirow[b]{2}{*}{ Marker species } & \multirow{2}{*}{$\begin{array}{c}\text { Age } \\
(\mathrm{Ma})\end{array}$} & \multicolumn{4}{|c|}{ Depth CSF (m) } \\
\hline Top & Bottom & & & Top & Bottom & Midpoint & \pm \\
\hline & & ligocene/Miocene boundary & & & & & \\
\hline $37 \mathrm{H}-\mathrm{CC}$ & $38 \mathrm{H}-\mathrm{CC}$ & B Paragloborotalia kugleri & 23.00 & 344.06 & 352.84 & 348.45 & 4.39 \\
\hline $42 X-C C$ & $43 X-C C$ & B Paragloborotalia pseudokugleri & 25.20 & 386.64 & 394.88 & 390.76 & 4.12 \\
\hline
\end{tabular}

Note: $\mathrm{T}=$ top, $\mathrm{B}=$ bottom.

Table T9. Distribution of planktonic foraminifers, Site U1335. This table is available in an oversized format.

Table T10. Distribution of benthic foraminifers, Site U1335. This table is available in an oversized format. 
Table T11. Coring-disturbed intervals and gaps, Site U1335. (See table notes.)

\begin{tabular}{|c|c|}
\hline $\begin{array}{l}\text { Core, section, } \\
\text { interval }(\mathrm{cm})\end{array}$ & Type of disturbance \\
\hline \multicolumn{2}{|l|}{ 320-U1335A- } \\
\hline $1 \mathrm{H}-1,0-9$ & Top of core \\
\hline $1 \mathrm{H}-2,145-150$ & Interstitial water \\
\hline $1 \mathrm{H}-4,145-150$ & Interstitial water \\
\hline $2 \mathrm{H}-1,0-34$ & Top of core \\
\hline $2 \mathrm{H}-2,145-150$ & Interstitial water \\
\hline $2 \mathrm{H}-5,145-150$ & Interstitial water \\
\hline $3 \mathrm{H}-1,0-48$ & Top of core \\
\hline $3 \mathrm{H}-2,145-150$ & Interstitial water \\
\hline $3 \mathrm{H}-5,145-150$ & Interstitial water \\
\hline $4 \mathrm{H}-1,0-120$ & Top of core \\
\hline $4 \mathrm{H}-2,145-150$ & Interstitial water \\
\hline $4 \mathrm{H}-5,145-150$ & Interstitial water \\
\hline $5 \mathrm{H}-1,0-45$ & Top of core \\
\hline $5 \mathrm{H}-2,145-150$ & Interstitial water \\
\hline $6 \mathrm{H}-1,0-28$ & Top of core \\
\hline $6 \mathrm{H}-2,145-150$ & Interstitial water \\
\hline $6 \mathrm{H}-5,145-150$ & Interstitial water \\
\hline $7 \mathrm{H}-3,140-150$ & Interstitial water \\
\hline $8 \mathrm{H}-1,0-9$ & Top of core \\
\hline $8 \mathrm{H}-3,140-150$ & Interstitial water \\
\hline $9 \mathrm{H}-3,18-23$ & Paleontology sample \\
\hline $10 \mathrm{H}-1,0-41$ & Top of core \\
\hline $10 \mathrm{H}-3,145-150$ & Interstitial water \\
\hline $11 \mathrm{H}-1,0-150$ & Top of core \\
\hline $11 \mathrm{H}-2,0-139$ & Disturbed \\
\hline $11 \mathrm{H}-2,140-150$ & Interstitial water \\
\hline $11 \mathrm{H}-3,0-150$ & Disturbed \\
\hline $11 \mathrm{H}-4,0-150$ & Disturbed \\
\hline $11 \mathrm{H}-5,0-150$ & Disturbed \\
\hline $11 \mathrm{H}-6,0-150$ & Disturbed \\
\hline $11 \mathrm{H}-7,0-42$ & Disturbed \\
\hline $12 \mathrm{H}-1,0-12$ & Top of core \\
\hline $12 \mathrm{H}-3,140-150$ & Interstitial water \\
\hline $13 \mathrm{H}-1,0-68$ & Top of core \\
\hline $13 \mathrm{H}-3,140-150$ & Interstitial water \\
\hline $13 \mathrm{H}-3,149-150$ & Paleontology sample \\
\hline $14 \mathrm{H}-1,0-51$ & Top of core \\
\hline $14 \mathrm{H}-3,140-150$ & Interstitial water \\
\hline $15 \mathrm{H}-1,0-56$ & Top of core \\
\hline $15 \mathrm{H}-3,140-150$ & Interstitial water \\
\hline $16 \mathrm{H}-1,0-10$ & Top of core \\
\hline $16 \mathrm{H}-3,140-150$ & Interstitial water \\
\hline $16 \mathrm{H}-4,25-150$ & Flow-in \\
\hline $16 \mathrm{H}-5,0-150$ & Flow-in \\
\hline $16 \mathrm{H}-6,0-150$ & Flow-in \\
\hline $16 \mathrm{H}-7,0-45$ & Flow-in \\
\hline $17 \mathrm{H}-1,0-69$ & Top of core \\
\hline $17 \mathrm{H}-3,140-150$ & Interstitial water \\
\hline $18 \mathrm{H}-1,0-25$ & Slurry \\
\hline $18 \mathrm{H}-3,140-150$ & Interstitial water \\
\hline $19 \mathrm{H}-3,140-150$ & Interstitial water \\
\hline $20 \mathrm{H}-1,0-7$ & Top of core \\
\hline $20 \mathrm{H}-3,140-150$ & Interstitial water \\
\hline $21 \mathrm{H}-1,0-35$ & Top of core \\
\hline $21 \mathrm{H}-3,140-150$ & Interstitial water \\
\hline $22 \mathrm{H}-1,0-94$ & Top of core \\
\hline $22 \mathrm{H}-3,140-150$ & Interstitial water \\
\hline $23 \mathrm{H}-1,0-130$ & Top of core \\
\hline $23 \mathrm{H}-2,70-150$ & Disturbed \\
\hline $23 \mathrm{H}-3,0-100$ & Disturbed \\
\hline
\end{tabular}

\begin{tabular}{|c|c|}
\hline $\begin{array}{l}\text { Core, section, } \\
\text { interval }(\mathrm{cm})\end{array}$ & Type of disturbance \\
\hline $23 \mathrm{H}-3,100-141$ & Biscuits \\
\hline $23 \mathrm{H}-3,140-150$ & Interstitial water \\
\hline $24 \mathrm{H}-1,57-150$ & Biscuits \\
\hline $24 \mathrm{H}-2,0-47$ & Biscuits \\
\hline $24 \mathrm{H}-2,74-85$ & Flow-in \\
\hline $24 \mathrm{H}-2,85-150$ & Biscuits \\
\hline $24 \mathrm{H}-3,140-150$ & Interstitial water \\
\hline $24 \mathrm{H}-5,0-79$ & Biscuits \\
\hline $25 \mathrm{H}-3,140-150$ & Interstitial water \\
\hline $26 \mathrm{H}-3,140-150$ & Interstitial water \\
\hline $27 \mathrm{H}-3,140-150$ & Interstitial water \\
\hline $28 \mathrm{H}-3,140-150$ & Interstitial water \\
\hline $29 \mathrm{H}-3,140-150$ & Interstitial water \\
\hline $30 \mathrm{H}-1,0-14$ & Top of core \\
\hline $30 \mathrm{H}-3,140-150$ & Interstitial water \\
\hline $31 \mathrm{H}-3,140-150$ & Interstitial water \\
\hline $32 \mathrm{H}-3,140-150$ & Interstitial water \\
\hline $33 \mathrm{H}-3,140-150$ & Interstitial water \\
\hline $34 \mathrm{H}-3,140-150$ & Interstitial water \\
\hline $34 \mathrm{H}-7,78-151$ & Flow-in \\
\hline $34 \mathrm{H}-8,0-72$ & Flow-in \\
\hline $35 \mathrm{H}-5,92-150$ & Flow-in \\
\hline $35 \mathrm{H}-6,0-81$ & Flow-in \\
\hline $36 \mathrm{H}-1,0-150$ & Top of core \\
\hline $36 \mathrm{H}-2,0-150$ & Top of core \\
\hline $36 \mathrm{H}-3,0-62$ & Top of core \\
\hline $37 X-45 X$, all sections & Drilling biscuits \\
\hline \multicolumn{2}{|l|}{ 320-U1335B- } \\
\hline $2 \mathrm{H}-1,0-74$ & Top of core \\
\hline $4 \mathrm{H}-1,0-80$ & Top of core \\
\hline $5 \mathrm{H}-1,0-20$ & Top of core \\
\hline $6 \mathrm{H}-1,0-16$ & Top of core \\
\hline 7H-1, 0-46 & Top of core \\
\hline $8 \mathrm{H}-1,0-13$ & Top of core \\
\hline $9 \mathrm{H}-1,0-40$ & Top of core \\
\hline $11 \mathrm{H}-5,140-150$ & Whole-round sample \\
\hline $13 \mathrm{H}-1,0-14$ & Top of core \\
\hline $15 \mathrm{H}-1,0-32$ & Top of core \\
\hline $16 \mathrm{H}-1,0-49$ & Top of core \\
\hline $17 \mathrm{H}-1,0-84$ & Top of core \\
\hline $18 \mathrm{H}-1,0-110$ & Top of core \\
\hline $20 \mathrm{H}-1,0-20$ & Top of core \\
\hline $21 \mathrm{H}-1,0-42$ & Top of core \\
\hline $22 \mathrm{H}-1,0-51$ & Top of core \\
\hline $22 \mathrm{H}-2,140-150$ & Whole-round sample \\
\hline $23 \mathrm{H}-1,0-50$ & Top of core \\
\hline $25 \mathrm{H}-1,0-46$ & Top of core \\
\hline $30 \mathrm{H}-1,0-5$ & Top of core \\
\hline $31 \mathrm{H}-1,8-12$ & Disturbed \\
\hline $31 \mathrm{H}-1,83-91$ & Disturbed \\
\hline $33 \mathrm{H}-5,140-150$ & Whole-round sample \\
\hline $36 \mathrm{H}-3,140-150$ & Interstitial water \\
\hline $37 \mathrm{H}-2,140-150$ & Interstitial water \\
\hline $38 \mathrm{H}-1,0-2$ & Top of core \\
\hline $38 \mathrm{H}-6,79-145$ & Flow-in \\
\hline $39 \mathrm{H}-1,0-2$ & Top of core \\
\hline $39 \mathrm{H}-3,140-150$ & Interstitial water \\
\hline $40 \mathrm{H}-1,0-6$ & Top of core \\
\hline $41 \mathrm{H}-1,0-3$ & Top of core \\
\hline $42 \mathrm{X}-46 \mathrm{X}$, all sections & Drilling biscuits \\
\hline
\end{tabular}

Notes: Top of core $=$ myriad forms of voids, disturbance, and debris from uphole that affect top portion of most cores. For that reason, probably the top $20 \mathrm{~cm}$ or so of all cores should be avoided. 
Table T12. Paleomagnetic data from archive-half sections, Hole U1335A, at $0 \mathrm{mT}$ AF demagnetization. (See table notes.)

\begin{tabular}{|c|c|c|c|c|c|c|}
\hline $\begin{array}{l}\text { Core, } \\
\text { section }\end{array}$ & $\begin{array}{l}\text { Offset } \\
(\mathrm{m})\end{array}$ & $\begin{array}{l}\text { Depth CSF } \\
\quad(\mathrm{m})\end{array}$ & $\begin{array}{l}\text { Declination } \\
\left({ }^{\circ}\right)\end{array}$ & $\begin{array}{c}\text { Inclination } \\
\left({ }^{\circ}\right)\end{array}$ & $\begin{array}{l}\text { Intensity } \\
(\mathrm{A} / \mathrm{m})\end{array}$ & $\begin{array}{l}\text { Time } \\
(\mathrm{s})\end{array}$ \\
\hline \multicolumn{7}{|c|}{ 320-U1335A- } \\
\hline $1 \mathrm{H}-1$ & 0.100 & 0.100 & 93.7 & -6.6 & $6.445 \mathrm{E}-03$ & 3322849274.76562 \\
\hline $1 \mathrm{H}-1$ & 0.150 & 0.150 & 62.2 & 3.6 & $2.542 \mathrm{E}-03$ & 3322849280.09375 \\
\hline $1 \mathrm{H}-1$ & 0.200 & 0.200 & 336.5 & 72.6 & $1.930 \mathrm{E}-03$ & 3322849285.42187 \\
\hline $1 \mathrm{H}-1$ & 0.250 & 0.250 & 81.7 & 24.5 & $3.273 \mathrm{E}-03$ & 3322849290.75000 \\
\hline $1 \mathrm{H}-1$ & 0.300 & 0.300 & 74.6 & 26.2 & $1.734 \mathrm{E}-03$ & 3322849296.06250 \\
\hline $1 \mathrm{H}-1$ & 0.350 & 0.350 & 106.1 & 30.4 & $1.484 \mathrm{E}-03$ & 3322849301.39062 \\
\hline $1 \mathrm{H}-1$ & 0.400 & 0.400 & 102.1 & 26.2 & $2.012 \mathrm{E}-03$ & 3322849306.71875 \\
\hline $1 \mathrm{H}-1$ & 0.450 & 0.450 & 110.3 & 14.5 & $3.365 \mathrm{E}-03$ & 3322849312.03125 \\
\hline $1 \mathrm{H}-1$ & 0.500 & 0.500 & 104.6 & 17.0 & $4.146 \mathrm{E}-03$ & 3322849317.35937 \\
\hline $1 \mathrm{H}-1$ & 0.550 & 0.550 & 114.2 & 16.9 & $5.322 \mathrm{E}-03$ & 3322849322.68750 \\
\hline $1 \mathrm{H}-1$ & 0.600 & 0.600 & 122.1 & 20.2 & $5.628 \mathrm{E}-03$ & 3322849328.01562 \\
\hline $1 \mathrm{H}-1$ & 0.650 & 0.650 & 126.4 & 23.9 & $5.074 \mathrm{E}-03$ & 3322849333.34375 \\
\hline $1 \mathrm{H}-1$ & 0.700 & 0.700 & 119.1 & 20.9 & $6.714 \mathrm{E}-03$ & 3322849338.65625 \\
\hline $1 \mathrm{H}-1$ & 0.750 & 0.750 & 118.8 & 17.9 & $7.110 \mathrm{E}-03$ & 3322849343.98437 \\
\hline $1 \mathrm{H}-1$ & 0.800 & 0.800 & 119.1 & 17.6 & $6.510 \mathrm{E}-03$ & 3322849349.31250 \\
\hline $1 \mathrm{H}-1$ & 0.850 & 0.850 & 118.1 & 20.4 & $6.783 \mathrm{E}-03$ & 3322849354.64062 \\
\hline $1 \mathrm{H}-1$ & 0.900 & 0.900 & 127.5 & 24.7 & $5.409 \mathrm{E}-03$ & 3322849359.96875 \\
\hline $1 \mathrm{H}-1$ & 0.950 & 0.950 & 110.1 & 14.3 & $4.068 \mathrm{E}-03$ & 3322849365.28125 \\
\hline $1 \mathrm{H}-1$ & 1.000 & 1.000 & 101.6 & 16.4 & $3.064 \mathrm{E}-03$ & 3322849370.60937 \\
\hline $1 \mathrm{H}-1$ & 1.050 & 1.050 & 134.7 & 22.5 & $4.764 \mathrm{E}-03$ & 3322849375.93750 \\
\hline $1 \mathrm{H}-1$ & 1.100 & 1.100 & 139.5 & 22.2 & $5.204 \mathrm{E}-03$ & 3322849381.26562 \\
\hline $1 \mathrm{H}-1$ & 1.150 & 1.150 & 122.8 & 21.1 & $4.343 \mathrm{E}-03$ & 3322849386.57812 \\
\hline $1 \mathrm{H}-1$ & 1.200 & 1.200 & 125.5 & 19.8 & $4.728 \mathrm{E}-03$ & 3322849391.90625 \\
\hline $1 \mathrm{H}-1$ & 1.250 & 1.250 & 147.6 & 4.0 & $6.640 \mathrm{E}-03$ & 3322849397.23437 \\
\hline $1 \mathrm{H}-1$ & 1.300 & 1.300 & 114.5 & -13.2 & 1.017E-02 & 3322849402.56250 \\
\hline $1 \mathrm{H}-1$ & 1.350 & 1.350 & 104.1 & 3.6 & $6.861 \mathrm{E}-03$ & 3322849407.89062 \\
\hline $1 \mathrm{H}-1$ & 1.400 & 1.400 & 135.8 & 18.8 & $5.656 \mathrm{E}-03$ & 3322849413.21875 \\
\hline $1 \mathrm{H}-2$ & 0.100 & 1.600 & 138.7 & 11.4 & 8.087E-03 & 3322850832.31250 \\
\hline $1 \mathrm{H}-2$ & 0.150 & 1.650 & 135.7 & 14.1 & $5.576 \mathrm{E}-03$ & 3322850837.64062 \\
\hline $1 \mathrm{H}-2$ & 0.200 & 1.700 & 133.6 & 14.4 & $4.534 \mathrm{E}-03$ & 3322850842.96875 \\
\hline $1 \mathrm{H}-2$ & 0.250 & 1.750 & 129.6 & 13.7 & $6.217 \mathrm{E}-03$ & 3322850848.29687 \\
\hline $1 \mathrm{H}-2$ & 0.300 & 1.800 & 135.9 & 12.5 & 7.053E-03 & 3322850853.60937 \\
\hline $1 \mathrm{H}-2$ & 0.350 & 1.850 & 135.4 & 12.2 & $7.722 \mathrm{E}-03$ & 3322850858.93750 \\
\hline $1 \mathrm{H}-2$ & 0.400 & 1.900 & 138.3 & 14.0 & $6.300 \mathrm{E}-03$ & 3322850864.26562 \\
\hline $1 \mathrm{H}-2$ & 0.450 & 1.950 & 134.3 & 13.9 & $6.638 \mathrm{E}-03$ & 3322850869.59375 \\
\hline $1 \mathrm{H}-2$ & 0.500 & 2.000 & 132.6 & 13.8 & $7.602 \mathrm{E}-03$ & 3322850874.90625 \\
\hline $1 \mathrm{H}-2$ & 0.550 & 2.050 & 136.2 & 13.0 & $8.158 \mathrm{E}-03$ & 3322850880.23437 \\
\hline $1 \mathrm{H}-2$ & 0.600 & 2.100 & 135.0 & 13.2 & $8.066 \mathrm{E}-03$ & 3322850885.56250 \\
\hline $1 \mathrm{H}-2$ & 0.650 & 2.150 & 139.4 & 14.6 & $6.468 \mathrm{E}-03$ & 3322850890.89062 \\
\hline $1 \mathrm{H}-2$ & 0.700 & 2.200 & 137.2 & 13.6 & $5.856 \mathrm{E}-03$ & 3322850896.20312 \\
\hline $1 \mathrm{H}-2$ & 0.750 & 2.250 & 135.2 & 13.0 & $7.960 \mathrm{E}-03$ & 3322850901.53125 \\
\hline $1 \mathrm{H}-2$ & 0.800 & 2.300 & 132.5 & 13.6 & $8.825 \mathrm{E}-03$ & 3322850906.85937 \\
\hline $1 \mathrm{H}-2$ & 0.850 & 2.350 & 135.7 & 12.5 & $9.411 \mathrm{E}-03$ & 3322850912.18750 \\
\hline $1 \mathrm{H}-2$ & 0.900 & 2.400 & 135.3 & 14.7 & $9.278 \mathrm{E}-03$ & 3322850917.51562 \\
\hline $1 \mathrm{H}-2$ & 0.950 & 2.450 & 135.5 & 14.7 & $9.415 \mathrm{E}-03$ & 3322850922.84375 \\
\hline $1 \mathrm{H}-2$ & 1.000 & 2.500 & 135.6 & 14.0 & $9.319 \mathrm{E}-03$ & 3322850928.15625 \\
\hline $1 \mathrm{H}-2$ & 1.050 & 2.550 & 141.3 & 16.2 & 7.987E-03 & 3322850933.48437 \\
\hline $1 \mathrm{H}-2$ & 1.100 & 2.600 & 139.7 & 14.0 & $6.436 \mathrm{E}-03$ & 3322850938.81250 \\
\hline $1 \mathrm{H}-2$ & 1.150 & 2.650 & 132.5 & 19.8 & $4.464 \mathrm{E}-03$ & 3322850944.14062 \\
\hline $1 \mathrm{H}-2$ & 1.200 & 2.700 & 149.3 & 19.0 & 4.137E-03 & 3322850949.46875 \\
\hline $1 \mathrm{H}-2$ & 1.250 & 2.750 & 144.3 & 16.2 & $4.475 \mathrm{E}-03$ & 3322850954.79687 \\
\hline $1 \mathrm{H}-2$ & 1.300 & 2.800 & 134.4 & 13.9 & $5.791 \mathrm{E}-03$ & 3322850960.10937 \\
\hline $1 \mathrm{H}-2$ & 1.350 & 2.850 & 151.1 & 24.0 & $5.858 \mathrm{E}-03$ & 3322850965.43750 \\
\hline $1 \mathrm{H}-2$ & 1.400 & 2.900 & 131.9 & 16.8 & $7.771 \mathrm{E}-03$ & 3322850970.76562 \\
\hline $1 \mathrm{H}-3$ & 0.100 & 3.100 & 138.8 & 11.2 & $7.612 \mathrm{E}-03$ & 3322851803.90625 \\
\hline $1 \mathrm{H}-3$ & 0.150 & 3.150 & 141.1 & 9.5 & $6.436 \mathrm{E}-03$ & 3322851809.21875 \\
\hline $1 \mathrm{H}-3$ & 0.200 & 3.200 & 135.1 & 10.2 & 4.291E-03 & 3322851814.54687 \\
\hline $1 \mathrm{H}-3$ & 0.250 & 3.250 & 140.8 & 13.7 & $3.941 \mathrm{E}-03$ & 3322851819.87500 \\
\hline $1 \mathrm{H}-3$ & 0.300 & 3.300 & 138.2 & 13.6 & $4.270 \mathrm{E}-03$ & 3322851825.18750 \\
\hline $1 \mathrm{H}-3$ & 0.350 & 3.350 & 139.6 & 13.4 & 4.367E-03 & 3322851830.51562 \\
\hline $1 \mathrm{H}-3$ & 0.400 & 3.400 & 138.8 & 16.4 & $4.836 \mathrm{E}-03$ & 3322851835.84375 \\
\hline
\end{tabular}

Notes: Time $=$ since 1 January 1904. Only a portion of this table appears here. The complete table is available in ASCII. 
Table T13. Paleomagnetic data from archive-half sections, Hole U1335A, at $20 \mathrm{mT}$ AF demagnetization. (See table notes.)

\begin{tabular}{|c|c|c|c|c|c|c|c|c|c|c|c|c|c|c|}
\hline \multirow{3}{*}{$\begin{array}{l}\text { Core, } \\
\text { section }\end{array}$} & \multirow{3}{*}{$\begin{array}{l}\text { Offset } \\
(\mathrm{m})\end{array}$} & \multirow{3}{*}{$\begin{array}{c}\text { Depth } \\
\text { CSF }(m)\end{array}$} & \multirow{3}{*}{$\begin{array}{c}\text { Declination } \\
\left({ }^{\circ}\right)\end{array}$} & \multirow{3}{*}{$\begin{array}{l}\text { Inclination } \\
\left({ }^{\circ}\right)\end{array}$} & \multirow{3}{*}{$\begin{array}{c}\text { Intensity } \\
(A / m)\end{array}$} & \multirow{3}{*}{$\underset{(s)}{\text { Time }}$} & \multicolumn{3}{|c|}{ Declination } & \multirow{3}{*}{$\begin{array}{c}\text { CCSF } \\
\text { offset } \\
\text { (m) }\end{array}$} & \multirow{2}{*}{\multicolumn{2}{|c|}{ Depth (m) }} & \multirow{2}{*}{\multicolumn{2}{|c|}{$\operatorname{VGP}\left({ }^{\circ}\right)$}} \\
\hline & & & & & & & & Geogra & oordinates & & & & & \\
\hline & & & & & & & $\left({ }^{\circ}\right)$ & $0^{\circ}-360^{\circ}$ & $-90^{\circ}-270^{\circ}$ & & CCSF-A & CCSF-B & Latitude & Longitude \\
\hline \multicolumn{15}{|c|}{ 320-U1335A- } \\
\hline $1 \mathrm{H}-1$ & 0.100 & 0.100 & 87.0 & 2.8 & $2.112 \mathrm{E}-03$ & 3322850308.59375 & 109.8 & 337.2 & -22.8 & 0.14 & 0.24 & 0.21 & 66.9 & 134.9 \\
\hline $1 \mathrm{H}-1$ & 0.125 & 0.125 & 76.9 & 6.4 & $2.030 \mathrm{E}-03$ & 3322850313.53125 & 109.8 & 327.1 & -32.9 & 0.14 & 0.27 & 0.23 & 57.1 & 141.5 \\
\hline $1 \mathrm{H}-1$ & 0.150 & 0.150 & 72.8 & 10.1 & $2.249 \mathrm{E}-03$ & 3322850318.45312 & 109.8 & 323.0 & -37.0 & 0.14 & 0.29 & 0.25 & 53.2 & -214.8 \\
\hline $1 \mathrm{H}-1$ & 0.175 & 0.175 & 71.3 & 8.3 & 2.037E-03 & 3322850323.39062 & 109.8 & 321.5 & -38.5 & 0.14 & 0.32 & 0.27 & 51.6 & -216.2 \\
\hline $1 \mathrm{H}-1$ & 0.200 & 0.200 & 70.4 & 10.0 & $1.574 \mathrm{E}-03$ & 3322850328.32812 & 109.8 & 320.6 & -39.4 & 0.14 & 0.34 & 0.29 & 50.8 & -214.7 \\
\hline $1 \mathrm{H}-1$ & 0.225 & 0.225 & 70.0 & 13.4 & $1.220 \mathrm{E}-03$ & 3322850333.25000 & 109.8 & 320.2 & -39.8 & 0.14 & 0.37 & 0.32 & 50.4 & -211.9 \\
\hline $1 \mathrm{H}-1$ & 0.250 & 0.250 & 71.3 & 18.7 & $1.033 \mathrm{E}-03$ & 3322850338.18750 & 109.8 & 321.5 & -38.5 & 0.14 & 0.39 & 0.34 & 51.6 & -207.4 \\
\hline $1 \mathrm{H}-1$ & 0.275 & 0.275 & 50.8 & 43.8 & $5.224 \mathrm{E}-04$ & 3322850343.12500 & 109.8 & 301.0 & -59.0 & 0.14 & 0.42 & 0.36 & 30.2 & -189.6 \\
\hline $1 \mathrm{H}-1$ & 0.300 & 0.300 & 73.6 & 23.7 & $8.704 \mathrm{E}-04$ & 3322850348.06250 & 109.8 & 323.8 & -36.2 & 0.14 & 0.44 & 0.38 & 53.6 & -202.5 \\
\hline $1 \mathrm{H}-1$ & 0.325 & 0.325 & 75.1 & 27.0 & 7.409E-04 & 3322850352.98437 & 109.8 & 325.3 & -34.7 & 0.14 & 0.47 & 0.40 & 54.7 & -198.9 \\
\hline $1 \mathrm{H}-1$ & 0.350 & 0.350 & 82.0 & 30.4 & $6.924 \mathrm{E}-04$ & 3322850357.92187 & 109.8 & 332.2 & -27.8 & 0.14 & 0.49 & 0.42 & 60.6 & -191.9 \\
\hline $1 \mathrm{H}-1$ & 0.375 & 0.375 & 95.5 & 28.2 & $8.162 \mathrm{E}-04$ & 3322850362.85937 & 109.8 & 345.7 & -14.3 & 0.14 & 0.52 & 0.45 & 72.9 & -180.5 \\
\hline $1 \mathrm{H}-1$ & 0.400 & 0.400 & 99.4 & 24.8 & $1.055 \mathrm{E}-03$ & 3322850367.78125 & 109.8 & 349.6 & -10.4 & 0.14 & 0.54 & 0.47 & 77.2 & -178.6 \\
\hline $1 \mathrm{H}-1$ & 0.425 & 0.425 & 102.5 & 21.0 & $1.389 \mathrm{E}-03$ & 3322850372.71875 & 109.8 & 352.7 & -7.3 & 0.14 & 0.57 & 0.49 & 80.9 & -178.2 \\
\hline $1 \mathrm{H}-1$ & 0.450 & 0.450 & 102.2 & 18.6 & $1.652 \mathrm{E}-03$ & 3322850377.65625 & 109.8 & 352.4 & -7.6 & 0.14 & 0.59 & 0.51 & 81.4 & -186.4 \\
\hline $1 \mathrm{H}-1$ & 0.475 & 0.475 & 100.9 & 15.0 & $2.098 \mathrm{E}-03$ & 3322850382.59375 & 109.8 & 351.1 & -8.9 & 0.14 & 0.62 & 0.53 & 80.9 & -201.0 \\
\hline $1 \mathrm{H}-1$ & 0.500 & 0.500 & 102.6 & 20.5 & $2.087 \mathrm{E}-03$ & 3322850387.51562 & 109.8 & 352.8 & -7.2 & 0.14 & 0.64 & 0.55 & 81.1 & -179.2 \\
\hline $1 \mathrm{H}-1$ & 0.525 & 0.525 & 104.4 & 16.9 & $2.070 \mathrm{E}-03$ & 3322850392.45312 & 109.8 & 354.6 & -5.4 & 0.14 & 0.67 & 0.58 & 83.7 & -184.1 \\
\hline $1 \mathrm{H}-1$ & 0.550 & 0.550 & 109.5 & 16.9 & $2.152 \mathrm{E}-03$ & 3322850397.39062 & 109.8 & 359.7 & -0.3 & 0.14 & 0.69 & 0.60 & 86.7 & -131.3 \\
\hline $1 \mathrm{H}-1$ & 0.575 & 0.575 & 118.9 & 15.4 & $2.484 \mathrm{E}-03$ & 3322850402.31250 & 109.8 & 9.1 & 9.1 & 0.14 & 0.72 & 0.62 & 80.6 & -52.3 \\
\hline $1 \mathrm{H}-1$ & 0.600 & 0.600 & 118.6 & 15.9 & $2.547 \mathrm{E}-03$ & 3322850407.25000 & 109.8 & 8.8 & 8.8 & 0.14 & 0.74 & 0.64 & 80.8 & -54.4 \\
\hline $1 \mathrm{H}-1$ & 0.625 & 0.625 & 119.9 & 17.0 & $2.516 \mathrm{E}-03$ & 3322850412.17187 & 109.8 & 10.1 & 10.1 & 0.14 & 0.77 & 0.66 & 79.4 & -55.4 \\
\hline $1 \mathrm{H}-1$ & 0.650 & 0.650 & 118.5 & 18.9 & $2.428 \mathrm{E}-03$ & 3322850417.10937 & 109.8 & 8.7 & 8.7 & 0.14 & 0.79 & 0.68 & 80.3 & -63.7 \\
\hline $1 \mathrm{H}-1$ & 0.675 & 0.675 & 112.3 & 22.0 & $2.613 \mathrm{E}-03$ & 3322850422.03125 & 109.8 & 2.5 & 2.5 & 0.14 & 0.82 & 0.71 & 83.4 & -104.3 \\
\hline $1 \mathrm{H}-1$ & 0.700 & 0.700 & 106.6 & 18.2 & $3.277 \mathrm{E}-03$ & 3322850426.96875 & 109.8 & 356.8 & -3.2 & 0.14 & 0.84 & 0.73 & 84.9 & -164.3 \\
\hline $1 \mathrm{H}-1$ & 0.725 & 0.725 & 109.8 & 18.4 & $3.368 \mathrm{E}-03$ & 3322850431.90625 & 109.8 & 0.0 & 0.0 & 0.14 & 0.87 & 0.75 & 85.9 & -126.2 \\
\hline $1 \mathrm{H}-1$ & 0.750 & 0.750 & 113.8 & 17.2 & $3.425 \mathrm{E}-03$ & 3322850436.82812 & 109.8 & 4.0 & 4.0 & 0.14 & 0.89 & 0.77 & 84.7 & -77.7 \\
\hline $1 \mathrm{H}-1$ & 0.775 & 0.775 & 117.9 & 15.8 & $3.284 \mathrm{E}-03$ & 3322850441.76562 & 109.8 & 8.1 & 8.1 & 0.14 & 0.92 & 0.79 & 81.5 & -55.4 \\
\hline $1 \mathrm{H}-1$ & 0.800 & 0.800 & 119.0 & 15.7 & $3.058 \mathrm{E}-03$ & 3322850446.68750 & 109.8 & 9.2 & 9.2 & 0.14 & 0.94 & 0.81 & 80.5 & -53.1 \\
\hline $1 \mathrm{H}-1$ & 0.825 & 0.825 & 118.4 & 17.2 & $2.941 \mathrm{E}-03$ & 3322850451.62500 & 109.8 & 8.6 & 8.6 & 0.14 & 0.97 & 0.83 & 80.8 & -58.9 \\
\hline $1 \mathrm{H}-1$ & 0.850 & 0.850 & 118.2 & 19.1 & $2.980 \mathrm{E}-03$ & 3322850456.54687 & 109.8 & 8.4 & 8.4 & 0.14 & 0.99 & 0.86 & 80.5 & -65.1 \\
\hline $1 \mathrm{H}-1$ & 0.875 & 0.875 & 117.8 & 21.0 & $3.008 \mathrm{E}-03$ & 3322850461.48437 & 109.8 & 8.0 & 8.0 & 0.14 & 1.02 & 0.88 & 80.3 & -71.7 \\
\hline $1 \mathrm{H}-1$ & 0.900 & 0.900 & 119.2 & 22.7 & $2.838 \mathrm{E}-03$ & 3322850466.40625 & 109.8 & 9.4 & 9.4 & 0.14 & 1.04 & 0.90 & 78.7 & -71.8 \\
\hline $1 \mathrm{H}-1$ & 0.925 & 0.925 & 118.7 & 22.8 & $2.532 \mathrm{E}-03$ & 3322850471.34375 & 109.8 & 8.9 & 8.9 & 0.14 & 1.07 & 0.92 & 79.0 & -73.5 \\
\hline $1 \mathrm{H}-1$ & 0.950 & 0.950 & 108.3 & 19.2 & $2.321 \mathrm{E}-03$ & 3322850476.28125 & 109.8 & 358.5 & -1.5 & 0.14 & 1.09 & 0.94 & 85.2 & -144.1 \\
\hline $1 \mathrm{H}-1$ & 0.975 & 0.975 & 80.8 & 10.6 & $2.254 \mathrm{E}-03$ & 3322850481.20312 & 109.8 & 331.0 & -29.0 & 0.14 & 1.12 & 0.96 & 61.1 & -214.7 \\
\hline $1 \mathrm{H}-1$ & 1.000 & 1.000 & 76.4 & 8.9 & $1.150 \mathrm{E}-03$ & 3322850486.14062 & 109.8 & 326.6 & -33.4 & 0.14 & 1.14 & 0.99 & 56.7 & -216.1 \\
\hline $1 \mathrm{H}-1$ & 1.025 & 1.025 & 93.9 & 9.8 & $1.508 \mathrm{E}-03$ & 3322850491.06250 & 109.8 & 344.1 & -15.9 & 0.14 & 1.17 & 1.01 & 74.2 & 143.2 \\
\hline $1 \mathrm{H}-1$ & 1.050 & 1.050 & 131.7 & 12.4 & $1.952 \mathrm{E}-03$ & 3322850496.00000 & 109.8 & 21.9 & 21.9 & 0.14 & 1.19 & 1.03 & 68.2 & -39.8 \\
\hline $1 \mathrm{H}-1$ & 1.075 & 1.075 & 123.7 & 14.5 & $2.059 \mathrm{E}-03$ & 3322850500.93750 & 109.8 & 13.9 & 13.9 & 0.14 & 1.22 & 1.05 & 76.0 & -45.4 \\
\hline $1 \mathrm{H}-1$ & 1.100 & 1.100 & 123.6 & 17.3 & $2.265 \mathrm{E}-03$ & 3322850505.85937 & 109.8 & 13.8 & 13.8 & 0.14 & 1.24 & 1.07 & 75.9 & -51.5 \\
\hline $1 \mathrm{H}-1$ & 1.125 & 1.125 & 123.6 & 16.4 & $2.247 \mathrm{E}-03$ & 3322850510.79687 & 109.8 & 13.8 & 13.8 & 0.14 & 1.27 & 1.09 & 76.0 & -49.5 \\
\hline $1 \mathrm{H}-1$ & 1.150 & 1.150 & 122.2 & 16.4 & $2.144 \mathrm{E}-03$ & 3322850515.73437 & 109.8 & 12.4 & 12.4 & 0.14 & 1.29 & 1.12 & 77.3 & -50.8 \\
\hline $1 \mathrm{H}-1$ & 1.175 & 1.175 & 120.1 & 15.5 & $2.088 \mathrm{E}-03$ & 3322850520.65625 & 109.8 & 10.3 & 10.3 & 0.14 & 1.32 & 1.14 & 79.4 & -50.9 \\
\hline
\end{tabular}

Notes: Time $=$ since 1 January 1904. VGP = virtual geomagnetic pole. Only a portion of this table appears here. The complete table is available in ASCII. 
Table T14. Paleomagnetic data from archive-half sections, Hole U1335B, at $0 \mathrm{mT}$ AF demagnetization. (See table notes.)

\begin{tabular}{|c|c|c|c|c|c|c|}
\hline $\begin{array}{l}\text { Core, } \\
\text { section, }\end{array}$ & $\begin{array}{l}\text { Offset } \\
(\mathrm{m})\end{array}$ & $\begin{array}{l}\text { Depth-CSF } \\
\text { (m) }\end{array}$ & $\begin{array}{l}\text { Declination } \\
\left({ }^{\circ}\right)\end{array}$ & $\begin{array}{c}\text { Inclination } \\
\left({ }^{\circ}\right)\end{array}$ & $\begin{array}{l}\text { Intensity } \\
(\mathrm{A} / \mathrm{m})\end{array}$ & $\begin{array}{l}\text { Time } \\
(\mathrm{s})\end{array}$ \\
\hline \multicolumn{7}{|c|}{ 320-U1335B- } \\
\hline $1 \mathrm{H}-1$ & 0.100 & 0.100 & 241.7 & -23.4 & $1.521 \mathrm{E}-02$ & 3323143964.25450 \\
\hline $1 \mathrm{H}-1$ & 0.150 & 0.150 & 241.4 & 16.5 & $6.560 \mathrm{E}-03$ & 3323143969.58262 \\
\hline $1 \mathrm{H}-1$ & 0.200 & 0.200 & 297.8 & 31.7 & $7.816 \mathrm{E}-03$ & 3323143974.91075 \\
\hline $1 \mathrm{H}-1$ & 0.250 & 0.250 & 267.9 & 16.5 & $6.816 \mathrm{E}-03$ & 3323143980.22325 \\
\hline $1 \mathrm{H}-1$ & 0.300 & 0.300 & 162.8 & -7.3 & $5.043 \mathrm{E}-03$ & 3323143985.55137 \\
\hline $1 \mathrm{H}-1$ & 0.350 & 0.350 & 215.2 & -2.2 & $1.216 \mathrm{E}-02$ & 3323143990.87950 \\
\hline $1 \mathrm{H}-1$ & 0.400 & 0.400 & 281.6 & 14.8 & $1.062 \mathrm{E}-02$ & 3323143996.20762 \\
\hline $1 \mathrm{H}-1$ & 0.450 & 0.450 & 346.1 & 27.3 & $2.661 \mathrm{E}-02$ & 3323144001.53575 \\
\hline $1 \mathrm{H}-1$ & 0.500 & 0.500 & 252.7 & 35.8 & $1.243 \mathrm{E}-02$ & 3323144006.84825 \\
\hline $1 \mathrm{H}-1$ & 0.550 & 0.550 & 138.1 & -12.9 & $3.402 \mathrm{E}-02$ & 3323144012.17637 \\
\hline $1 \mathrm{H}-1$ & 0.600 & 0.600 & 133.7 & 12.0 & 5.697E-02 & 3323144017.50450 \\
\hline $1 \mathrm{H}-1$ & 0.650 & 0.650 & 191.3 & 37.3 & $8.961 \mathrm{E}-02$ & 3323144022.83262 \\
\hline $1 \mathrm{H}-1$ & 0.700 & 0.700 & 236.5 & 23.5 & $3.344 \mathrm{E}-02$ & 3323144028.16075 \\
\hline $1 \mathrm{H}-1$ & 0.750 & 0.750 & 309.4 & 65.1 & $3.304 \mathrm{E}-03$ & 3323144033.47325 \\
\hline $1 \mathrm{H}-1$ & 0.800 & 0.800 & 166.8 & 5.8 & $1.026 \mathrm{E}-02$ & 3323144038.80137 \\
\hline $1 \mathrm{H}-1$ & 0.850 & 0.850 & 188.9 & 19.4 & $6.260 \mathrm{E}-03$ & 3323144044.12950 \\
\hline $1 \mathrm{H}-1$ & 0.900 & 0.900 & 221.1 & 19.6 & $6.313 \mathrm{E}-03$ & 3323144049.45762 \\
\hline $1 \mathrm{H}-1$ & 0.950 & 0.950 & 218.9 & 18.7 & $6.722 \mathrm{E}-03$ & 3323144054.77012 \\
\hline $1 \mathrm{H}-1$ & 1.000 & 1.000 & 213.5 & 16.8 & $6.649 \mathrm{E}-03$ & 3323144060.09825 \\
\hline $1 \mathrm{H}-1$ & 1.050 & 1.050 & 207.6 & 16.8 & $4.581 \mathrm{E}-03$ & 3323144065.42637 \\
\hline $1 \mathrm{H}-1$ & 1.100 & 1.100 & 208.0 & 22.8 & $2.816 \mathrm{E}-03$ & 3323144070.75450 \\
\hline $1 \mathrm{H}-1$ & 1.150 & 1.150 & 210.6 & 20.9 & $3.395 \mathrm{E}-03$ & 3323144076.08262 \\
\hline $1 \mathrm{H}-1$ & 1.200 & 1.200 & 208.5 & 23.9 & $4.012 \mathrm{E}-03$ & 3323144081.39512 \\
\hline $1 \mathrm{H}-1$ & 1.250 & 1.250 & 205.1 & 18.5 & $4.632 \mathrm{E}-03$ & 3323144086.72325 \\
\hline $1 \mathrm{H}-1$ & 1.300 & 1.300 & 203.1 & 15.8 & $5.234 \mathrm{E}-03$ & 3323144092.05137 \\
\hline $1 \mathrm{H}-1$ & 1.350 & 1.350 & 204.8 & 16.5 & $5.093 \mathrm{E}-03$ & 3323144097.37950 \\
\hline $1 \mathrm{H}-1$ & 1.400 & 1.400 & 209.9 & 19.5 & $5.489 \mathrm{E}-03$ & 3323144102.70762 \\
\hline $1 \mathrm{H}-2$ & 0.100 & 1.600 & 220.6 & 12.1 & $8.470 \mathrm{E}-03$ & 3323145023.41075 \\
\hline $1 \mathrm{H}-2$ & 0.150 & 1.650 & 228.1 & 15.1 & $7.126 \mathrm{E}-03$ & 3323145028.73887 \\
\hline $1 \mathrm{H}-2$ & 0.200 & 1.700 & 222.5 & 19.4 & $7.549 \mathrm{E}-03$ & 3323145034.06700 \\
\hline $1 \mathrm{H}-2$ & 0.250 & 1.750 & 221.2 & 17.4 & $7.890 \mathrm{E}-03$ & 3323145039.39512 \\
\hline $1 \mathrm{H}-2$ & 0.300 & 1.800 & 222.4 & 18.4 & 7.527E-03 & 3323145044.72325 \\
\hline $1 \mathrm{H}-2$ & 0.350 & 1.850 & 226.9 & 18.6 & $6.061 \mathrm{E}-03$ & 3323145050.03575 \\
\hline $1 \mathrm{H}-2$ & 0.400 & 1.900 & 221.9 & 16.5 & $5.695 \mathrm{E}-03$ & 3323145055.36387 \\
\hline $1 \mathrm{H}-2$ & 0.450 & 1.950 & 218.4 & 13.5 & $7.212 \mathrm{E}-03$ & 3323145060.69200 \\
\hline $1 \mathrm{H}-2$ & 0.500 & 2.000 & 215.3 & 13.1 & $8.220 \mathrm{E}-03$ & 3323145066.02012 \\
\hline $1 \mathrm{H}-2$ & 0.550 & 2.050 & 213.4 & 13.8 & $8.322 \mathrm{E}-03$ & 3323145071.34825 \\
\hline $1 \mathrm{H}-2$ & 0.600 & 2.100 & 216.1 & 14.9 & $7.534 \mathrm{E}-03$ & 3323145076.67637 \\
\hline $1 \mathrm{H}-2$ & 0.650 & 2.150 & 218.2 & 14.9 & $7.228 \mathrm{E}-03$ & 3323145081.98887 \\
\hline $1 \mathrm{H}-2$ & 0.700 & 2.200 & 215.3 & 14.2 & $7.334 \mathrm{E}-03$ & 3323145087.31700 \\
\hline $1 \mathrm{H}-2$ & 0.750 & 2.250 & 213.2 & 12.9 & $7.788 \mathrm{E}-03$ & 3323145092.64512 \\
\hline $1 \mathrm{H}-2$ & 0.800 & 2.300 & 214.1 & 11.3 & $7.983 \mathrm{E}-03$ & 3323145097.97325 \\
\hline $1 \mathrm{H}-2$ & 0.850 & 2.350 & 215.0 & 10.6 & $8.143 \mathrm{E}-03$ & 3323145103.30137 \\
\hline $1 \mathrm{H}-2$ & 0.900 & 2.400 & 215.8 & 11.5 & 8.095E-03 & 3323145108.62950 \\
\hline $1 \mathrm{H}-2$ & 0.950 & 2.450 & 215.8 & 13.4 & $7.962 \mathrm{E}-03$ & 3323145113.94200 \\
\hline $1 \mathrm{H}-2$ & 1.000 & 2.500 & 215.3 & 15.2 & $8.135 \mathrm{E}-03$ & 3323145119.27012 \\
\hline $1 \mathrm{H}-2$ & 1.050 & 2.550 & 212.1 & 17.7 & 9.047E-03 & 3323145124.59825 \\
\hline $1 \mathrm{H}-2$ & 1.100 & 2.600 & 210.3 & 18.8 & $9.152 \mathrm{E}-03$ & 3323145129.91075 \\
\hline $1 \mathrm{H}-2$ & 1.150 & 2.650 & 209.7 & 19.1 & $9.207 \mathrm{E}-03$ & 3323145135.23887 \\
\hline $1 \mathrm{H}-2$ & 1.200 & 2.700 & 209.6 & 17.8 & $9.752 \mathrm{E}-03$ & 3323145140.56700 \\
\hline $1 \mathrm{H}-2$ & 1.250 & 2.750 & 212.0 & 17.5 & $9.672 \mathrm{E}-03$ & 3323145145.89512 \\
\hline $1 \mathrm{H}-2$ & 1.300 & 2.800 & 216.5 & 14.7 & $8.434 \mathrm{E}-03$ & 3323145151.22325 \\
\hline $1 \mathrm{H}-2$ & 1.350 & 2.850 & 222.2 & 16.5 & $6.775 \mathrm{E}-03$ & 3323145156.55137 \\
\hline $1 \mathrm{H}-2$ & 1.400 & 2.900 & 224.8 & 16.2 & $5.793 \mathrm{E}-03$ & 3323145161.87950 \\
\hline $1 \mathrm{H}-3$ & 0.075 & 3.075 & 184.9 & 20.9 & $5.988 \mathrm{E}-03$ & 3323146071.20762 \\
\hline $1 \mathrm{H}-3$ & 0.100 & 3.100 & 174.4 & 20.3 & $6.969 \mathrm{E}-03$ & 3323146076.14512 \\
\hline $1 \mathrm{H}-3$ & 0.125 & 3.125 & 170.5 & 17.9 & $8.804 \mathrm{E}-03$ & 3323146081.06700 \\
\hline $1 \mathrm{H}-3$ & 0.150 & 3.150 & 162.2 & 16.2 & $1.086 \mathrm{E}-02$ & 3323146086.00450 \\
\hline $1 \mathrm{H}-3$ & 0.175 & 3.175 & 150.2 & 13.8 & $1.381 \mathrm{E}-02$ & 3323146090.92637 \\
\hline $1 \mathrm{H}-3$ & 0.200 & 3.200 & 143.2 & 13.9 & $1.601 \mathrm{E}-02$ & 3323146095.86387 \\
\hline $1 \mathrm{H}-3$ & 0.225 & 3.225 & 155.5 & 23.2 & 1.107E-02 & 3323146100.78575 \\
\hline $1 \mathrm{H}-3$ & 0.250 & 3.250 & 280.9 & 11.5 & 2.617E-02 & 3323146105.72325 \\
\hline $1 \mathrm{H}-3$ & 0.275 & 3.275 & 289.4 & 3.3 & $7.721 \mathrm{E}-02$ & 3323146110.66075 \\
\hline $2 \mathrm{H}-1$ & 0.750 & 4.050 & 142.1 & 31.5 & $4.702 \mathrm{E}-03$ & 3323148890.89512 \\
\hline
\end{tabular}

Notes: Time $=$ since 1 January 1904 . Only a portion of this table appears here. The complete table is available in ASCII. 
Table T15. Paleomagnetic data from archive-half sections, Hole U1335B, at $20 \mathrm{mT}$ AF demagnetization. (See table notes.)

\begin{tabular}{|c|c|c|c|c|c|c|c|c|c|c|c|c|c|c|}
\hline \multirow{3}{*}{$\begin{array}{l}\text { Core, } \\
\text { section }\end{array}$} & \multirow{3}{*}{$\begin{array}{l}\text { Offset } \\
(\mathrm{m})\end{array}$} & \multirow{3}{*}{$\begin{array}{l}\text { Depth } \\
\text { CSF (m) }\end{array}$} & \multirow{3}{*}{$\begin{array}{l}\text { Declination } \\
\left({ }^{\circ}\right)\end{array}$} & \multirow{3}{*}{$\begin{array}{c}\text { Inclination } \\
\left(^{(}\right)\end{array}$} & \multirow{3}{*}{$\begin{array}{l}\text { Intensity } \\
(\mathrm{A} / \mathrm{m})\end{array}$} & \multirow{3}{*}{$\underset{(s)}{\text { Time }}$} & \multicolumn{3}{|c|}{ Declination } & \multirow{3}{*}{$\begin{array}{l}\text { CCSF } \\
\text { offset } \\
\text { (m) }\end{array}$} & \multirow{2}{*}{\multicolumn{2}{|c|}{ Depth $(\mathrm{m})$}} & \multirow{2}{*}{\multicolumn{2}{|c|}{$\operatorname{VGP}\left({ }^{\circ}\right)$}} \\
\hline & & & & & & & \multirow{2}{*}{$\begin{array}{c}\text { Core mean } \\
\left({ }^{\circ}\right)\end{array}$} & \multicolumn{2}{|c|}{ Geographical coordinates } & & & & & \\
\hline & & & & & & & & $0^{\circ}-360^{\circ}$ & $-90^{\circ}-270^{\circ}$ & & CCSF-A & CCSF-B & Latitude & Longitude \\
\hline \multicolumn{15}{|c|}{ 320-U1335B- } \\
\hline $1 \mathrm{H}-1 \mathrm{~A}$ & 0.075 & 0.075 & 169.8 & -44.0 & $6.562 \mathrm{E}-03$ & 3323144406.11387 & 200.6 & 329.2 & -30.8 & 0.00 & 0.08 & 0.06 & 46.9 & 96.2 \\
\hline $1 \mathrm{H}-1 \mathrm{~A}$ & 0.100 & 0.100 & 229.1 & -35.3 & $1.022 \mathrm{E}-02$ & 3323144411.05137 & 200.6 & 28.5 & 28.5 & 0.00 & 0.10 & 0.09 & 52.6 & 6.1 \\
\hline $1 \mathrm{H}-1 \mathrm{~A}$ & 0.125 & 0.125 & 242.9 & -20.6 & $1.158 \mathrm{E}-02$ & 3323144415.98887 & 200.6 & 42.3 & 42.3 & 0.00 & 0.13 & 0.11 & 45.0 & -15.4 \\
\hline $1 \mathrm{H}-1 \mathrm{~A}$ & 0.150 & 0.150 & 249.3 & -4.6 & $1.103 \mathrm{E}-02$ & 3323144420.91075 & 200.6 & 48.7 & 48.7 & 0.00 & 0.15 & 0.13 & 40.8 & -28.5 \\
\hline $1 \mathrm{H}-1 \mathrm{~A}$ & 0.175 & 0.175 & 236.1 & 5.1 & $5.436 \mathrm{E}-03$ & 3323144425.84825 & 200.6 & 35.5 & 35.5 & 0.00 & 0.18 & 0.15 & 54.5 & -33.1 \\
\hline $1 \mathrm{H}-1 \mathrm{~A}$ & 0.200 & 0.200 & 239.9 & 24.0 & $2.549 \mathrm{E}-03$ & 3323144430.78575 & 200.6 & 39.3 & 39.3 & 0.00 & 0.20 & 0.17 & 50.6 & -49.5 \\
\hline $1 \mathrm{H}-1 \mathrm{~A}$ & 0.225 & 0.225 & 258.7 & 36.3 & $2.720 \mathrm{E}-03$ & 3323144435.72325 & 200.6 & 58.1 & 58.1 & 0.00 & 0.23 & 0.19 & 31.7 & -56.6 \\
\hline $1 \mathrm{H}-1 \mathrm{~A}$ & 0.250 & 0.250 & 278.6 & 26.4 & $4.080 \mathrm{E}-03$ & 3323144440.64512 & 200.6 & 78.0 & 78.0 & 0.00 & 0.25 & 0.22 & 12.9 & -49.3 \\
\hline $1 \mathrm{H}-1 \mathrm{~A}$ & 0.275 & 0.275 & 278.3 & 18.0 & $4.513 \mathrm{E}-03$ & 3323144445.58262 & 200.6 & 77.7 & 77.7 & 0.00 & 0.28 & 0.24 & 13.0 & -44.5 \\
\hline $1 \mathrm{H}-1 \mathrm{~A}$ & 0.300 & 0.300 & 267.9 & 5.1 & $2.000 \mathrm{E}-03$ & 3323144450.52012 & 200.6 & 67.3 & 67.3 & 0.00 & 0.30 & 0.26 & 22.8 & -36.7 \\
\hline $1 \mathrm{H}-1 \mathrm{~A}$ & 0.325 & 0.325 & 151.2 & -0.1 & $1.474 \mathrm{E}-03$ & 3323144455.45762 & 200.6 & 310.6 & -49.4 & 0.00 & 0.33 & 0.28 & 40.4 & 139.2 \\
\hline $1 \mathrm{H}-1 \mathrm{~A}$ & 0.350 & 0.350 & 164.3 & -8.2 & $2.265 \mathrm{E}-03$ & 3323144460.37950 & 200.6 & 323.7 & -36.3 & 0.00 & 0.35 & 0.30 & 52.5 & 129.9 \\
\hline $1 \mathrm{H}-1 \mathrm{~A}$ & 0.375 & 0.375 & 202.8 & -8.3 & $4.345 \mathrm{E}-03$ & 3323144465.31700 & 200.6 & 2.2 & 2.2 & 0.00 & 0.38 & 0.32 & 80.3 & 40.7 \\
\hline $1 \mathrm{H}-1 \mathrm{~A}$ & 0.400 & 0.400 & 224.1 & -1.0 & $7.813 \mathrm{E}-03$ & 3323144470.23887 & 200.6 & 23.5 & 23.5 & 0.00 & 0.40 & 0.35 & 65.8 & -23.0 \\
\hline $1 \mathrm{H}-1 \mathrm{~A}$ & 0.425 & 0.425 & 237.4 & 5.5 & $7.694 \mathrm{E}-03$ & 3323144475.17637 & 200.6 & 36.8 & 36.8 & 0.00 & 0.43 & 0.37 & 53.2 & -33.7 \\
\hline $1 \mathrm{H}-1 \mathrm{~A}$ & 0.450 & 0.450 & 275.1 & 17.0 & $5.486 \mathrm{E}-03$ & 3323144480.11387 & 200.6 & 74.5 & 74.5 & 0.00 & 0.45 & 0.39 & 16.1 & -43.7 \\
\hline $1 \mathrm{H}-1 \mathrm{~A}$ & 0.475 & 0.475 & 348.8 & 24.9 & $6.479 \mathrm{E}-03$ & 3323144485.03575 & 200.6 & 148.2 & 148.2 & 0.00 & 0.48 & 0.41 & -53.5 & -66.6 \\
\hline $1 \mathrm{H}-1 \mathrm{~A}$ & 0.500 & 0.500 & 11.5 & 26.9 & $8.511 \mathrm{E}-03$ & 3323144489.97325 & 200.6 & 170.9 & 170.9 & 0.00 & 0.50 & 0.43 & -68.5 & -101.5 \\
\hline $1 \mathrm{H}-1 \mathrm{~A}$ & 0.525 & 0.525 & 15.2 & 30.8 & $7.448 \mathrm{E}-03$ & 3323144494.91075 & 200.6 & 174.6 & 174.6 & 0.00 & 0.53 & 0.45 & -67.4 & -112.6 \\
\hline $1 \mathrm{H}-1 \mathrm{~A}$ & 0.550 & 0.550 & 358.4 & 58.1 & $2.532 \mathrm{E}-03$ & 3323144499.84825 & 200.6 & 157.8 & 157.8 & 0.00 & 0.55 & 0.48 & -41.4 & -103.1 \\
\hline $1 \mathrm{H}-1 \mathrm{~A}$ & 0.575 & 0.575 & 208.3 & 11.4 & $2.461 \mathrm{E}-03$ & 3323144504.78575 & 200.6 & 7.7 & 7.7 & 0.00 & 0.58 & 0.50 & 82.3 & -39.9 \\
\hline $1 \mathrm{H}-1 \mathrm{~A}$ & 0.600 & 0.600 & 141.7 & -5.5 & $9.288 \mathrm{E}-03$ & 3323144509.70762 & 200.6 & 301.1 & -58.9 & 0.00 & 0.60 & 0.52 & 30.6 & 137.4 \\
\hline $1 \mathrm{H}-1 \mathrm{~A}$ & 0.625 & 0.625 & 158.5 & -0.7 & $2.001 \mathrm{E}-02$ & 3323144514.64512 & 200.6 & 317.9 & -42.1 & 0.00 & 0.63 & 0.54 & 47.6 & 137.5 \\
\hline $1 \mathrm{H}-1 \mathrm{~A}$ & 0.650 & 0.650 & 174.9 & 7.3 & $2.590 \mathrm{E}-02$ & 3323144519.58262 & 200.6 & 334.3 & -25.7 & 0.00 & 0.65 & 0.56 & 64.3 & 141.2 \\
\hline $1 \mathrm{H}-1 \mathrm{~A}$ & 0.675 & 0.675 & 183.8 & 16.9 & $3.047 \mathrm{E}-02$ & 3323144524.52012 & 200.6 & 343.2 & -16.8 & 0.00 & 0.68 & 0.58 & 73.0 & -204.0 \\
\hline $1 \mathrm{H}-1 \mathrm{~A}$ & 0.700 & 0.700 & 195.6 & 26.8 & $3.011 \mathrm{E}-02$ & 3323144529.44200 & 200.6 & 355.0 & -5.0 & 0.00 & 0.70 & 0.60 & 79.9 & -154.9 \\
\hline $1 \mathrm{H}-1 \mathrm{~A}$ & 0.725 & 0.725 & 205.6 & 27.4 & $2.329 \mathrm{E}-02$ & 3323144534.48887 & 200.6 & 5.0 & 5.0 & 0.00 & 0.73 & 0.63 & 79.6 & -98.5 \\
\hline $1 \mathrm{H}-1 \mathrm{~A}$ & 0.750 & 0.750 & 224.0 & 19.8 & $1.472 \mathrm{E}-02$ & 3323144539.59825 & 200.6 & 23.4 & 23.4 & 0.00 & 0.75 & 0.65 & 66.3 & -49.5 \\
\hline $1 \mathrm{H}-1 \mathrm{~A}$ & 0.775 & 0.775 & 251.8 & 29.2 & $4.489 \mathrm{E}-03$ & 3323144544.91075 & 200.6 & 51.2 & 51.2 & 0.00 & 0.78 & 0.67 & 38.7 & -52.0 \\
\hline $1 \mathrm{H}-1 \mathrm{~A}$ & 0.800 & 0.800 & 291.2 & 47.5 & $1.794 \mathrm{E}-03$ & 3323144549.84825 & 200.6 & 90.6 & 90.6 & 0.00 & 0.80 & 0.69 & 2.0 & -64.7 \\
\hline $1 \mathrm{H}-1 \mathrm{~A}$ & 0.825 & 0.825 & 198.2 & 34.8 & $1.274 \mathrm{E}-03$ & 3323144554.78575 & 200.6 & 357.6 & -2.4 & 0.00 & 0.83 & 0.71 & 76.0 & -135.6 \\
\hline $1 \mathrm{H}-1 \mathrm{~A}$ & 0.850 & 0.850 & 169.4 & 9.6 & $3.117 \mathrm{E}-03$ & 3323144559.70762 & 200.6 & 328.8 & -31.2 & 0.00 & 0.85 & 0.73 & 58.9 & -215.6 \\
\hline $1 \mathrm{H}-1 \mathrm{~A}$ & 0.875 & 0.875 & 170.5 & 7.5 & $3.913 \mathrm{E}-03$ & 3323144564.64512 & 200.6 & 329.9 & -30.1 & 0.00 & 0.88 & 0.76 & 60.0 & 142.2 \\
\hline $1 \mathrm{H}-1 \mathrm{~A}$ & 0.900 & 0.900 & 172.1 & 10.9 & $3.524 \mathrm{E}-03$ & 3323144569.56700 & 200.6 & 331.5 & -28.5 & 0.00 & 0.90 & 0.78 & 61.6 & -214.4 \\
\hline $1 \mathrm{H}-1 \mathrm{~A}$ & 0.925 & 0.925 & 200.8 & 18.9 & $3.137 \mathrm{E}-03$ & 3323144574.50450 & 200.6 & 0.2 & 0.2 & 0.00 & 0.93 & 0.80 & 85.6 & -123.6 \\
\hline $1 \mathrm{H}-1 \mathrm{~A}$ & 0.950 & 0.950 & 221.6 & 18.3 & $3.177 \mathrm{E}-03$ & 3323144579.45762 & 200.6 & 21.0 & 21.0 & 0.00 & 0.95 & 0.82 & 68.8 & -48.5 \\
\hline $1 \mathrm{H}-1 \mathrm{~A}$ & 0.975 & 0.975 & 219.4 & 17.9 & $3.465 \mathrm{E}-03$ & 3323144584.37950 & 200.6 & 18.8 & 18.8 & 0.00 & 0.98 & 0.84 & 71.0 & -49.0 \\
\hline $1 \mathrm{H}-1 \mathrm{~A}$ & 1.000 & 1.000 & 218.1 & 18.5 & $3.536 \mathrm{E}-03$ & 3323144589.31700 & 200.6 & 17.5 & 17.5 & 0.00 & 1.00 & 0.86 & 72.2 & -50.8 \\
\hline $1 \mathrm{H}-1 \mathrm{~A}$ & 1.025 & 1.025 & 216.3 & 17.9 & $3.634 \mathrm{E}-03$ & 3323144594.25450 & 200.6 & 15.7 & 15.7 & 0.00 & 1.03 & 0.89 & 74.0 & -51.0 \\
\hline $1 \mathrm{H}-1 \mathrm{~A}$ & 1.050 & 1.050 & 214.2 & 16.8 & $3.632 \mathrm{E}-03$ & 3323144599.19200 & 200.6 & 13.6 & 13.6 & 0.00 & 1.05 & 0.91 & 76.1 & -50.6 \\
\hline $1 \mathrm{H}-1 \mathrm{~A}$ & 1.075 & 1.075 & 211.5 & 16.0 & $3.472 \mathrm{E}-03$ & 3323144604.11387 & 200.6 & 10.9 & 10.9 & 0.00 & 1.08 & 0.93 & 78.8 & -51.5 \\
\hline $1 \mathrm{H}-1 \mathrm{~A}$ & 1.100 & 1.100 & 208.4 & 15.6 & $3.081 \mathrm{E}-03$ & 3323144609.05137 & 200.6 & 7.8 & 7.8 & 0.00 & 1.10 & 0.95 & 81.8 & -55.4 \\
\hline $1 \mathrm{H}-1 \mathrm{~A}$ & 1.125 & 1.125 & 208.1 & 15.6 & $2.549 \mathrm{E}-03$ & 3323144613.98887 & 200.6 & 7.5 & 7.5 & 0.00 & 1.13 & 0.97 & 82.1 & -56.1 \\
\hline
\end{tabular}

Notes: Time $=$ since 1 January 1904. Only a portion of this table appears here. The complete table is available in ASCII. 
Table T16. Mean paleomagnetic direction for each core, Site U1335. (See table notes.)

\begin{tabular}{|c|c|c|c|c|}
\hline Core & $\begin{array}{c}\text { Inclination } \\
\left(^{\circ}\right)\end{array}$ & $\begin{array}{c}\text { Declination } \\
\left(^{\circ}\right)\end{array}$ & $N$ & $\begin{array}{c}\alpha 95 \\
\left({ }^{\circ}\right)\end{array}$ \\
\hline \multicolumn{5}{|c|}{ 320-U1335A- } \\
\hline $1 \mathrm{H}$ & 10.7 & 109.8 & 317 & 3.1 \\
\hline $2 \mathrm{H}$ & 7.7 & 223.5 & 344 & 2.0 \\
\hline $3 \mathrm{H}$ & 1.1 & 164.2 & 331 & 3.1 \\
\hline $4 \mathrm{H}$ & -2.7 & 315.0 & 310 & 2.8 \\
\hline $5 \mathrm{H}$ & -8.9 & 87.6 & 173 & 5.2 \\
\hline $6 \mathrm{H}$ & -0.2 & 191.9 & 224 & 11.6 \\
\hline $7 \mathrm{H}$ & 12.9 & 103.6 & 254 & 4.0 \\
\hline $8 \mathrm{H}-16 \mathrm{H}$ & NA & NA & NA & NA \\
\hline $17 \mathrm{H}$ & -14.6 & 118.9 & 158 & 4.2 \\
\hline $18 \mathrm{H}$ & 4.2 & 76.7 & 171 & 3.4 \\
\hline $19 \mathrm{H}$ & -10.5 & 116.9 & 327 & 1.4 \\
\hline $20 \mathrm{H}$ & 3.5 & 266.8 & 173 & 2.2 \\
\hline $21 \mathrm{H}$ & 17.8 & 38.3 & 159 & 4.0 \\
\hline $22 \mathrm{H}$ & -57.8 & 179.5 & 153 & 4.1 \\
\hline $23 \mathrm{H}-36 \mathrm{H}$ & NA & NA & NA & NA \\
\hline \multicolumn{5}{|c|}{ 320-U1335B- } \\
\hline $1 \mathrm{H}$ & 19.8 & 200.6 & 119 & 2.9 \\
\hline $2 \mathrm{H}$ & 4.5 & 207.9 & 321 & 2.0 \\
\hline $3 \mathrm{H}$ & 2.5 & 15.1 & 343 & 2.7 \\
\hline $4 \mathrm{H}$ & -75.9 & 251.0 & 313 & 3.0 \\
\hline $5 \mathrm{H}$ & -64.6 & 9.9 & 347 & 7.2 \\
\hline $6 \mathrm{H}$ & -16.3 & 206.1 & 344 & 5.6 \\
\hline $7 \mathrm{H}$ & 43.7 & 272.1 & 343 & 9.9 \\
\hline $8 \mathrm{H}$ & 4.1 & 81.8 & 346 & 2.1 \\
\hline $9 \mathrm{H}-12 \mathrm{H}$ & NA & NA & NA & NA \\
\hline $13 \mathrm{H}$ & 5.0 & 248.6 & 345 & 2.8 \\
\hline $14 \mathrm{H}$ & 4.7 & 284.8 & 346 & 4.4 \\
\hline $15 \mathrm{H}$ & -10.2 & 187.7 & 348 & 2.0 \\
\hline $16 \mathrm{H}$ & -9.2 & 292.6 & 332 & 2.7 \\
\hline $17 \mathrm{H}$ & 21.6 & 253.0 & 308 & 6.1 \\
\hline $18 \mathrm{H}$ & -1.6 & 276.0 & 289 & 2.0 \\
\hline $19 \mathrm{H}$ & 0.5 & 272.8 & 358 & 1.3 \\
\hline $20 \mathrm{H}$ & -13.3 & 71.3 & 350 & 1.6 \\
\hline $21 \mathrm{H}$ & 2.0 & 204.2 & 301 & 2.0 \\
\hline $22 \mathrm{H}$ & 45.6 & 272.1 & 231 & 5.9 \\
\hline $23 \mathrm{H}-41 \mathrm{H}$ & NA & NA & NA & NA \\
\hline
\end{tabular}

Notes: Mean paleomagnetic directions and statistics calculated using Bingham statistics for each core. We used data from stable polarity intervals. Reversed polarity intervals were inverted prior to computing mean directions and statistics. Inclination = mean paleomagnetic inclination from stable polarity intervals in core, declination = mean paleomagnetic declination from stable polarity intervals in core. By subtracting this value from observed paleomagnetic declinations measured along core, core can be approximately reoriented back into geographic coordinates. After reorientation, normal polarity intervals will have $\sim 0^{\circ}$ declination and reversed polarity intervals will have $\sim 180^{\circ}$ declination. $\mathrm{N}=$ number of paleomagnetic observations used in calculating mean, $\alpha 95=95 \%$ confidence angle for mean direction. 
Table T17. Paleomagnetic results for discrete samples, Hole U1335A. (See table notes.)

\begin{tabular}{|c|c|c|c|c|c|c|c|}
\hline \multirow{3}{*}{$\begin{array}{l}\text { Core, section, } \\
\text { interval }(\mathrm{cm})\end{array}$} & \multirow{3}{*}{$\begin{array}{l}\text { Depth } \\
\text { CSF }(m)\end{array}$} & \multirow{3}{*}{$\begin{array}{l}\text { Demag } \\
(\mathrm{mT})\end{array}$} & \multicolumn{3}{|c|}{ Declination } & \multirow{3}{*}{$\begin{array}{c}\text { Inclination } \\
\left({ }^{\circ}\right)\end{array}$} & \multirow{3}{*}{$\begin{array}{l}\text { Intensity } \\
(\mathrm{A} / \mathrm{m})\end{array}$} \\
\hline & & & \multirow{2}{*}{$\begin{array}{l}\text { Azimuthally } \\
\text { unoriented }\left({ }^{\circ}\right)\end{array}$} & \multicolumn{2}{|c|}{ Geographical coordinates } & & \\
\hline & & & & $0^{\circ}-360^{\circ}$ & $-90^{\circ}-270^{\circ}$ & & \\
\hline \multicolumn{8}{|l|}{ 320-U1335A- } \\
\hline $1 \mathrm{H}-2,90$ & 2.40 & 0 & 136.8 & 27.0 & 27.0 & 8.9 & $6.94 \mathrm{E}-03$ \\
\hline $1 \mathrm{H}-2,90$ & 2.40 & 5 & 134.5 & 24.7 & 24.7 & 8.9 & $4.69 \mathrm{E}-03$ \\
\hline $1 \mathrm{H}-2,90$ & 2.40 & 10 & 134.9 & 25.1 & 25.1 & 8.7 & $3.82 \mathrm{E}-03$ \\
\hline $1 \mathrm{H}-2,90$ & 2.40 & 15 & 138.3 & 28.5 & 28.5 & 8.7 & $3.62 \mathrm{E}-03$ \\
\hline $1 \mathrm{H}-2,90$ & 2.40 & 20 & 136.8 & 27.0 & 27.0 & 10.9 & $3.15 \mathrm{E}-03$ \\
\hline $1 \mathrm{H}-2,90$ & 2.40 & 25 & 138.5 & 28.7 & 28.7 & 12.8 & $2.85 \mathrm{E}-03$ \\
\hline $1 \mathrm{H}-2,90$ & 2.40 & 30 & 134.2 & 24.4 & 24.4 & 16.7 & $2.35 \mathrm{E}-03$ \\
\hline $1 \mathrm{H}-2,90$ & 2.40 & 35 & 133.5 & 23.7 & 23.7 & 21.5 & $1.95 \mathrm{E}-03$ \\
\hline $1 \mathrm{H}-2,90$ & 2.40 & 40 & 136.4 & 26.6 & 26.6 & 24.4 & $1.72 \mathrm{E}-03$ \\
\hline $1 \mathrm{H}-2,90$ & 2.40 & 50 & 133.3 & 23.5 & 23.5 & 43.0 & 1.37E-03 \\
\hline $1 \mathrm{H}-2,90$ & 2.40 & 60 & 141.1 & 31.3 & 31.3 & 46.2 & $1.15 \mathrm{E}-03$ \\
\hline $1 \mathrm{H}-4,85$ & 5.35 & 0 & -125.0 & 125.2 & 125.2 & 4.4 & $2.45 \mathrm{E}-03$ \\
\hline $1 \mathrm{H}-4,85$ & 5.35 & 5 & -94.3 & 155.9 & 155.9 & -3.6 & $2.89 \mathrm{E}-03$ \\
\hline $1 \mathrm{H}-4,85$ & 5.35 & 10 & -89.2 & 161.0 & 161.0 & -3.8 & $3.54 \mathrm{E}-03$ \\
\hline $1 \mathrm{H}-4,85$ & 5.35 & 15 & -94.9 & 155.3 & 155.3 & -3.4 & $3.35 \mathrm{E}-03$ \\
\hline $1 \mathrm{H}-4,85$ & 5.35 & 20 & -89.9 & 160.3 & 160.3 & -0.6 & $2.98 \mathrm{E}-03$ \\
\hline $1 \mathrm{H}-4,85$ & 5.35 & 25 & -90.0 & 160.2 & 160.2 & 3.0 & $2.52 \mathrm{E}-03$ \\
\hline $1 \mathrm{H}-4,85$ & 5.35 & 30 & -88.3 & 161.9 & 161.9 & 8.1 & $2.08 \mathrm{E}-03$ \\
\hline $1 \mathrm{H}-4,85$ & 5.35 & 35 & -86.9 & 163.3 & 163.3 & 15.2 & $1.64 \mathrm{E}-03$ \\
\hline $1 \mathrm{H}-4,85$ & 5.35 & 40 & -89.3 & 160.9 & 160.9 & 23.5 & $1.45 \mathrm{E}-03$ \\
\hline $1 \mathrm{H}-4,85$ & 5.35 & 50 & -96.5 & 153.7 & 153.7 & 44.2 & $1.08 \mathrm{E}-03$ \\
\hline $1 \mathrm{H}-4,85$ & 5.35 & 60 & -99.6 & 150.6 & 150.6 & 59.7 & $1.04 \mathrm{E}-03$ \\
\hline $1 \mathrm{H}-5,85$ & 6.85 & 0 & 108.6 & 358.8 & -1.2 & 13.4 & $1.84 \mathrm{E}-03$ \\
\hline $1 \mathrm{H}-5,85$ & 6.85 & 5 & 91.0 & 341.2 & -18.8 & 10.9 & $9.29 \mathrm{E}-04$ \\
\hline $1 \mathrm{H}-5,85$ & 6.85 & 10 & 90.6 & 340.8 & -19.2 & 8.0 & 5.40E-04 \\
\hline $1 \mathrm{H}-5,85$ & 6.85 & 15 & 60.3 & 310.5 & -49.5 & 13.3 & 4.84E-04 \\
\hline $1 \mathrm{H}-5,85$ & 6.85 & 20 & 36.1 & 286.3 & -73.7 & 18.8 & 6.37E-04 \\
\hline $1 \mathrm{H}-5,85$ & 6.85 & 25 & 68.0 & 318.2 & -41.8 & 31.2 & $4.14 \mathrm{E}-04$ \\
\hline $1 \mathrm{H}-5,85$ & 6.85 & 30 & 46.0 & 296.2 & -63.8 & 39.2 & 4.66E-04 \\
\hline $1 \mathrm{H}-5,85$ & 6.85 & 35 & 73.2 & 323.4 & -36.6 & 52.3 & 4.50E-04 \\
\hline $1 \mathrm{H}-5,85$ & 6.85 & 40 & 49.5 & 299.7 & -60.3 & 60.4 & 4.50E-04 \\
\hline $1 \mathrm{H}-5,85$ & 6.85 & 50 & 50.2 & 300.4 & -59.6 & 75.1 & 5.72E-04 \\
\hline $1 \mathrm{H}-5,85$ & 6.85 & 60 & 13.0 & 263.2 & 263.2 & 57.7 & $6.24 \mathrm{E}-04$ \\
\hline $2 \mathrm{H}-2,85$ & 11.25 & 0 & -1.2 & 135.3 & 135.3 & -22.0 & $1.45 \mathrm{E}-03$ \\
\hline $2 \mathrm{H}-2,85$ & 11.25 & 5 & 22.3 & 158.8 & 158.8 & -9.2 & $1.89 \mathrm{E}-03$ \\
\hline $2 \mathrm{H}-2,85$ & 11.25 & 10 & 23.7 & 160.2 & 160.2 & -9.5 & 2.37E-03 \\
\hline $2 \mathrm{H}-2,85$ & 11.25 & 15 & 23.7 & 160.2 & 160.2 & -8.6 & $2.22 \mathrm{E}-03$ \\
\hline $2 \mathrm{H}-2,85$ & 11.25 & 20 & 24.2 & 160.7 & 160.7 & -7.5 & $2.04 \mathrm{E}-03$ \\
\hline $2 \mathrm{H}-2,85$ & 11.25 & 25 & 23.4 & 159.9 & 159.9 & -3.8 & 1.77E-03 \\
\hline $2 \mathrm{H}-2,85$ & 11.25 & 30 & 23.1 & 159.6 & 159.6 & 3.8 & 1.37E-03 \\
\hline $2 \mathrm{H}-2,85$ & 11.25 & 35 & 22.2 & 158.7 & 158.7 & 9.7 & $1.26 \mathrm{E}-03$ \\
\hline $2 \mathrm{H}-2,85$ & 11.25 & 40 & 21.9 & 158.4 & 158.4 & 20.4 & $9.56 \mathrm{E}-04$ \\
\hline $2 \mathrm{H}-2,85$ & 11.25 & 50 & 12.1 & 148.6 & 148.6 & 43.6 & $9.66 \mathrm{E}-04$ \\
\hline $2 \mathrm{H}-2,85$ & 11.25 & 60 & 25.9 & 162.4 & 162.4 & 72.4 & $6.18 \mathrm{E}-04$ \\
\hline $2 \mathrm{H}-5,85$ & 15.75 & 0 & -136.5 & 0.0 & 0.0 & 11.4 & $4.14 \mathrm{E}-03$ \\
\hline $2 \mathrm{H}-5,85$ & 15.75 & 5 & -128.6 & 7.9 & 7.9 & 4.9 & $2.69 \mathrm{E}-03$ \\
\hline $2 \mathrm{H}-5,85$ & 15.75 & 10 & -131.8 & 4.7 & 4.7 & 2.9 & $2.11 \mathrm{E}-03$ \\
\hline $2 \mathrm{H}-5,85$ & 15.75 & 15 & -127.2 & 9.3 & 9.3 & 5.5 & 1.79E-03 \\
\hline $2 \mathrm{H}-5,85$ & 15.75 & 20 & -124.5 & 12.0 & 12.0 & 9.2 & $1.43 \mathrm{E}-03$ \\
\hline $2 \mathrm{H}-5,85$ & 15.75 & 25 & -138.3 & -1.8 & -1.8 & 8.8 & $1.45 \mathrm{E}-03$ \\
\hline $2 \mathrm{H}-5,85$ & 15.75 & 30 & -125.6 & 10.9 & 10.9 & 17.5 & $1.03 \mathrm{E}-03$ \\
\hline $2 \mathrm{H}-5,85$ & 15.75 & 35 & -128.4 & 8.1 & 8.1 & 24.9 & $8.68 \mathrm{E}-04$ \\
\hline $2 \mathrm{H}-5,85$ & 15.75 & 40 & -121.5 & 15.0 & 15.0 & 39.9 & 7.31E-04 \\
\hline $2 \mathrm{H}-5,85$ & 15.75 & 50 & -139.3 & -2.8 & -2.8 & 53.1 & $5.51 \mathrm{E}-04$ \\
\hline $2 \mathrm{H}-5,85$ & 15.75 & 60 & -105.0 & 31.5 & 31.5 & 74.3 & $6.01 \mathrm{E}-04$ \\
\hline $2 \mathrm{H}-7,50$ & 18.40 & 0 & -162.8 & -26.3 & -26.3 & 29.8 & $7.63 \mathrm{E}-04$ \\
\hline $2 \mathrm{H}-7,50$ & 18.40 & 5 & 61.7 & 198.2 & 198.2 & -5.4 & 7.14E-04 \\
\hline $2 \mathrm{H}-7,50$ & 18.40 & 10 & 59.8 & 196.3 & 196.3 & -5.6 & $1.23 \mathrm{E}-03$ \\
\hline $2 \mathrm{H}-7,50$ & 18.40 & 15 & 72.8 & 209.3 & 209.3 & -7.4 & $1.03 \mathrm{E}-03$ \\
\hline $2 \mathrm{H}-7,50$ & 18.40 & 20 & 49.4 & 185.9 & 185.9 & 0.9 & $1.25 \mathrm{E}-03$ \\
\hline $2 \mathrm{H}-7,50$ & 18.40 & 25 & 60.5 & 197.0 & 197.0 & 7.6 & $9.33 \mathrm{E}-04$ \\
\hline $2 \mathrm{H}-7,50$ & 18.40 & 30 & 59.1 & 195.6 & 195.6 & 14.1 & $7.90 \mathrm{E}-04$ \\
\hline
\end{tabular}

Notes: Only a portion of this table appears here. The complete table is available in ASCII. 
Table T18. Principal component analysis (PCA) results for paleomagnetic data, Hole U1335A. (See table notes.) (Continued on next page.)

\begin{tabular}{|c|c|c|c|c|c|c|c|c|c|c|}
\hline \multirow[b]{3}{*}{$\begin{array}{l}\text { Core, section, } \\
\text { interval }(\mathrm{cm})\end{array}$} & \multirow[b]{3}{*}{$\begin{array}{l}\text { Depth } \\
\text { CSF }(m)\end{array}$} & \multicolumn{5}{|c|}{ PCA } & \multirow[b]{3}{*}{$\begin{array}{l}\text { NRM } 20 \mathrm{mT} \\
\quad(\mathrm{A} / \mathrm{m})\end{array}$} & \multirow{2}{*}{\multicolumn{3}{|c|}{$\begin{array}{l}\text { Archive-half section at } 20 \mathrm{mT} \text { AF } \\
\text { demagnetization }\end{array}$}} \\
\hline & & \multicolumn{2}{|c|}{ Declination } & \multirow[b]{2}{*}{$\begin{array}{c}\text { Inclination } \\
\left({ }^{\circ}\right)\end{array}$} & \multirow[b]{2}{*}{$\begin{array}{c}\text { MAD } \\
\left({ }^{\circ}\right)\end{array}$} & \multirow[b]{2}{*}{$\begin{array}{l}\text { Range } \\
(\mathrm{mT})\end{array}$} & & & & \\
\hline & & $\begin{array}{l}\text { Azimuthally } \\
\text { unoriented }\left({ }^{\circ}\right)\end{array}$ & $\begin{array}{c}\text { Geographical } \\
\text { coordinates } \\
\left(0^{\circ}-360^{\circ}\right)\end{array}$ & & & & & $\begin{array}{c}\text { Declination } \\
\left({ }^{\circ}\right)\end{array}$ & $\begin{array}{l}\text { Inclination } \\
\left({ }^{\circ}\right)\end{array}$ & $\begin{array}{ll}\mathrm{NRM} \\
\\
\quad(\mathrm{A} / \mathrm{m})\end{array}$ \\
\hline \multicolumn{11}{|l|}{ 320-U1335A- } \\
\hline $1 \mathrm{H}-2,90$ & 2.40 & 136.4 & 26.6 & 8.0 & 4.6 & $0-20$ & $3.15 \mathrm{E}-03$ & 129.8 & 17.5 & $4.459 \mathrm{E}-03$ \\
\hline $1 \mathrm{H}-4,85$ & 5.35 & 264.3 & 154.5 & -19.3 & 8.3 & $10-35$ & $2.98 \mathrm{E}-03$ & 267.3 & 3.1 & $2.315 \mathrm{E}-03$ \\
\hline $1 \mathrm{H}-5,85$ & 6.85 & NA & NA & NA & NA & NA & $6.37 \mathrm{E}-04$ & 239.6 & 40.9 & 7.587E-04 \\
\hline $2 \mathrm{H}-2,85$ & 11.25 & 25.0 & 161.5 & -27.0 & 2.0 & $10-30$ & $2.04 \mathrm{E}-03$ & 38.1 & 4.0 & $1.371 \mathrm{E}-03$ \\
\hline $2 \mathrm{H}-5,85$ & 15.75 & 233.2 & 9.7 & -0.9 & 15.2 & $5-25$ & $1.43 \mathrm{E}-03$ & 221.7 & 8.9 & $2.845 \mathrm{E}-03$ \\
\hline $2 \mathrm{H}-7,85$ & 18.40 & NA & NA & NA & NA & NA & $1.25 \mathrm{E}-03$ & 65.8 & 13.5 & $1.333 \mathrm{E}-03$ \\
\hline $3 \mathrm{H}-2,85$ & 20.75 & 156.9 & 352.7 & -1.2 & 8.6 & $5-25$ & $4.46 \mathrm{E}-04$ & 170.6 & 42.5 & $1.205 \mathrm{E}-03$ \\
\hline $3 \mathrm{H}-4,85$ & 23.75 & 333.5 & 169.3 & -32.2 & 8.7 & $10-60$ & 1.87E-03 & 326.7 & -2.4 & $2.283 \mathrm{E}-03$ \\
\hline $3 \mathrm{H}-5,85$ & 25.25 & 162.9 & 358.7 & 2.9 & 7.7 & $5-25$ & $1.70 \mathrm{E}-03$ & 166.9 & 12.2 & $2.465 \mathrm{E}-03$ \\
\hline $4 \mathrm{H}-2,85$ & 30.25 & 115.3 & 160.3 & -23.6 & 8.4 & $10-30$ & 1.97E-03 & 120.7 & 21.6 & $2.648 \mathrm{E}-03$ \\
\hline $4 \mathrm{H}-5,85$ & 34.75 & 315.5 & 0.4 & 6.7 & 14.2 & $5-25$ & $1.12 \mathrm{E}-03$ & 307.2 & 24.9 & $1.119 \mathrm{E}-03$ \\
\hline $4 \mathrm{H}-7,60$ & 37.50 & 153.8 & 198.8 & -17.7 & 6.6 & $15-40$ & $1.84 \mathrm{E}-03$ & 142.9 & 20.9 & $1.724 \mathrm{E}-03$ \\
\hline $5 \mathrm{H}-2,110$ & 40.00 & 266.4 & 178.8 & 8.2 & 15.7 & $5-35$ & $3.30 \mathrm{E}-04$ & 256.9 & 21.2 & $1.932 \mathrm{E}-04$ \\
\hline $5 \mathrm{H}-4,85$ & 42.75 & NA & NA & NA & NA & NA & $8.45 \mathrm{E}-04$ & 72.7 & 12.0 & $7.612 \mathrm{E}-04$ \\
\hline $5 \mathrm{H}-5,85$ & 44.25 & 265.7 & 178.1 & 10.5 & 17.0 & $5-40$ & 7.97E-04 & 257.2 & 25.1 & $1.058 \mathrm{E}-03$ \\
\hline $6 \mathrm{H}-2,85$ & 49.25 & NA & NA & NA & NA & NA & $2.54 \mathrm{E}-04$ & 290.9 & 32.0 & $2.733 \mathrm{E}-04$ \\
\hline $7 \mathrm{H}-2,85$ & 58.75 & 256.9 & 153.3 & -35.8 & 7.4 & $10-30$ & $1.38 \mathrm{E}-03$ & 252.9 & 14.3 & $2.046 \mathrm{E}-03$ \\
\hline $7 \mathrm{H}-5,85$ & 63.25 & 115.3 & 11.7 & 2.1 & 11.1 & $5-25$ & $1.74 \mathrm{E}-03$ & 123.1 & 16.5 & $1.851 \mathrm{E}-03$ \\
\hline $7 \mathrm{H}-7,40$ & 65.80 & 126.7 & 23.1 & -14.3 & 15.4 & $5-30$ & $6.30 \mathrm{E}-04$ & 131.7 & 20.9 & $1.153 \mathrm{E}-03$ \\
\hline $8 \mathrm{H}-1,85$ & 66.75 & 130.7 & NA & -1.7 & 22.9 & $5-25$ & $1.92 \mathrm{E}-04$ & 131.7 & 51.5 & $4.609 \mathrm{E}-04$ \\
\hline $8 \mathrm{H}-2,85$ & 68.25 & 311.7 & NA & -19.3 & 19.4 & $5-35$ & $4.10 \mathrm{E}-04$ & 310.6 & 11.3 & $3.837 \mathrm{E}-04$ \\
\hline $8 \mathrm{H}-5,85$ & 72.75 & 164.1 & NA & -2.1 & 13.3 & $5-30$ & $1.36 \mathrm{E}-04$ & 136.6 & 15.8 & $4.854 \mathrm{E}-04$ \\
\hline $9 \mathrm{H}-2,85$ & 77.75 & NA & NA & NA & NA & NA & $1.39 \mathrm{E}-04$ & 218.0 & 40.9 & $1.900 \mathrm{E}-04$ \\
\hline $9 \mathrm{H}-5,85$ & 82.25 & NA & NA & NA & NA & NA & $1.14 \mathrm{E}-04$ & 124.4 & -47.0 & $5.435 \mathrm{E}-05$ \\
\hline $10 \mathrm{H}-2,85$ & 87.25 & NA & NA & NA & NA & NA & $7.60 \mathrm{E}-05$ & 290.5 & 25.5 & $1.363 \mathrm{E}-05$ \\
\hline $11 \mathrm{H}-2,85$ & 96.75 & 9.4 & NA & -25.6 & 5.5 & $5-25$ & $6.39 \mathrm{E}-05$ & NA & NA & NA \\
\hline $11 \mathrm{H}-5,85$ & 101.25 & 353.5 & NA & 2.0 & 19.3 & $10-30$ & 1.47E-04 & NA & NA & NA \\
\hline $12 \mathrm{H}-2,85$ & 106.25 & NA & NA & NA & NA & NA & $3.02 \mathrm{E}-05$ & 226.5 & 51.3 & $5.679 \mathrm{E}-05$ \\
\hline $12 \mathrm{H}-5,85$ & 110.75 & NA & NA & NA & NA & NA & $2.54 \mathrm{E}-04$ & 242.0 & 39.0 & $1.291 \mathrm{E}-04$ \\
\hline $13 \mathrm{H}-2,85$ & 115.75 & NA & NA & NA & NA & NA & $1.36 \mathrm{E}-04$ & 187.0 & 1.5 & $2.100 \mathrm{E}-04$ \\
\hline $13 \mathrm{H}-5,85$ & 120.25 & 38.4 & NA & -28.9 & 20.3 & $5-25$ & $2.70 \mathrm{E}-05$ & 186.3 & 23.0 & $2.738 \mathrm{E}-04$ \\
\hline $13 \mathrm{H}-7,60$ & 123.00 & NA & NA & NA & NA & NA & 1.47E-04 & 220.5 & 29.0 & $3.626 \mathrm{E}-04$ \\
\hline $14 \mathrm{H}-2,85$ & 125.25 & 88.7 & NA & -12.2 & 11.0 & $10-35$ & $9.88 \mathrm{E}-04$ & 87.7 & 6.6 & $1.666 \mathrm{E}-03$ \\
\hline $14 \mathrm{H}-5,85$ & 129.75 & 244.5 & NA & -11.7 & 10.8 & $5-30$ & $8.05 \mathrm{E}-04$ & 241.2 & 29.3 & $4.400 \mathrm{E}-04$ \\
\hline $14 \mathrm{H}-7,75$ & 132.60 & NA & NA & NA & NA & NA & $1.71 \mathrm{E}-04$ & 238.8 & 18.8 & $3.491 \mathrm{E}-04$ \\
\hline $15 \mathrm{H}-2,75$ & 134.65 & NA & NA & NA & NA & NA & $2.78 \mathrm{E}-04$ & 235.9 & 15.4 & $4.513 \mathrm{E}-04$ \\
\hline $15 \mathrm{H}-5,85$ & 138.75 & 131.0 & NA & -30.5 & 32.5 & $5-25$ & $2.23 \mathrm{E}-04$ & 143.6 & 56.1 & $4.541 \mathrm{E}-04$ \\
\hline $16 \mathrm{H}-2,85$ & 144.25 & NA & NA & NA & NA & NA & 3.77E-04 & 151.8 & 61.0 & $2.167 \mathrm{E}-04$ \\
\hline $17 \mathrm{H}-2,85$ & 153.75 & NA & NA & NA & NA & NA & $6.18 \mathrm{E}-05$ & 343.7 & 18.7 & $3.816 \mathrm{E}-04$ \\
\hline $17 \mathrm{H}-7,50$ & 160.90 & 307.9 & 189.0 & -21.4 & 6.9 & $20-40$ & $2.93 \mathrm{E}-03$ & 310.6 & 2.8 & $3.584 \mathrm{E}-03$ \\
\hline $18 \mathrm{H}-2,85$ & 163.25 & 229.2 & 152.5 & -10.2 & 16.9 & $5-50$ & 7.49E-04 & 246.9 & -3.2 & $6.911 \mathrm{E}-04$ \\
\hline $18 \mathrm{H}-5,85$ & 167.75 & 79.3 & 2.6 & -3.1 & 4.3 & $10-40$ & $1.52 \mathrm{E}-03$ & 78.0 & 3.9 & $1.565 \mathrm{E}-03$ \\
\hline $19 \mathrm{H}-2,85$ & 172.75 & 84.2 & 327.3 & -8.3 & 15.1 & $15-35$ & $9.20 \mathrm{E}-04$ & 107.5 & 17.9 & $1.336 \mathrm{E}-03$ \\
\hline $19 \mathrm{H}-5,85$ & 177.25 & 295.8 & 178.9 & -25.1 & 16.0 & $15-50$ & $6.11 \mathrm{E}-04$ & 339.9 & 34.7 & $3.788 \mathrm{E}-04$ \\
\hline $20 \mathrm{H}-2,85$ & 182.25 & 235.6 & 328.8 & 5.0 & 14.8 & $5-25$ & $5.68 \mathrm{E}-04$ & 265.1 & -2.7 & $6.262 \mathrm{E}-04$ \\
\hline $20 \mathrm{H}-5,85$ & 186.75 & 128.1 & 221.3 & -26.2 & 26.7 & $5-50$ & $5.85 \mathrm{E}-04$ & 111.4 & -15.1 & $3.742 \mathrm{E}-04$ \\
\hline $21 \mathrm{H}-2,85$ & 191.75 & NA & NA & NA & NA & NA & $1.50 \mathrm{E}-04$ & 256.0 & -9.5 & $1.186 \mathrm{E}-04$ \\
\hline $22 \mathrm{H}-2,85$ & 201.25 & NA & NA & NA & NA & NA & $5.82 \mathrm{E}-04$ & 16.3 & 31.1 & $4.475 \mathrm{E}-04$ \\
\hline $22 \mathrm{H}-3,85$ & 202.75 & NA & NA & NA & NA & NA & $2.42 \mathrm{E}-04$ & 13.3 & 52.6 & $4.269 \mathrm{E}-04$ \\
\hline $23 \mathrm{H}-2,90$ & 210.80 & NA & NA & NA & NA & NA & $1.30 \mathrm{E}-04$ & NA & NA & NA \\
\hline $24 \mathrm{H}-2,85$ & 220.25 & NA & NA & NA & NA & NA & $7.78 \mathrm{E}-05$ & NA & NA & NA \\
\hline $25 \mathrm{H}-2,75$ & 229.75 & NA & NA & NA & NA & NA & $8.15 \mathrm{E}-05$ & 234.4 & 11.8 & $2.238 \mathrm{E}-05$ \\
\hline $26 \mathrm{H}-2,85$ & 239.25 & NA & NA & NA & NA & NA & $5.21 \mathrm{E}-05$ & 135.7 & 26.6 & $1.128 \mathrm{E}-04$ \\
\hline $27 \mathrm{H}-2,85$ & 248.75 & NA & NA & NA & NA & NA & $2.37 \mathrm{E}-05$ & 198.7 & 66.5 & 2.097E-04 \\
\hline $28 \mathrm{H}-2,85$ & 258.25 & NA & NA & NA & NA & NA & $4.83 \mathrm{E}-04$ & 44.4 & 31.8 & $6.934 \mathrm{E}-04$ \\
\hline $29 \mathrm{H}-2,85$ & 267.75 & NA & NA & NA & NA & NA & $2.18 \mathrm{E}-04$ & 291.3 & 43.3 & $6.239 \mathrm{E}-05$ \\
\hline $30 \mathrm{H}-2,85$ & 277.25 & NA & NA & NA & NA & NA & 8.87E-05 & 207.7 & 20.5 & $5.990 \mathrm{E}-05$ \\
\hline $31 \mathrm{H}-2,85$ & 286.75 & NA & NA & NA & NA & NA & $2.43 \mathrm{E}-05$ & 320.1 & -27.0 & $2.427 \mathrm{E}-05$ \\
\hline $32 \mathrm{H}-2,85$ & 296.25 & NA & NA & NA & NA & NA & $1.11 \mathrm{E}-04$ & 297.8 & 55.8 & $3.387 \mathrm{E}-05$ \\
\hline $33 \mathrm{H}-2,85$ & 305.75 & NA & NA & NA & NA & NA & $9.40 \mathrm{E}-05$ & 243.8 & 73.4 & $1.260 \mathrm{E}-05$ \\
\hline $34 \mathrm{H}-3,85$ & 315.35 & NA & NA & NA & NA & NA & $9.65 \mathrm{E}-05$ & 266.4 & 61.7 & $1.930 \mathrm{E}-05$ \\
\hline $35 \mathrm{H}-2,85$ & 324.75 & NA & NA & NA & NA & NA & $6.46 \mathrm{E}-05$ & 241.0 & 53.3 & $1.277 \mathrm{E}-05$ \\
\hline $36 \mathrm{H}-2,85$ & 334.25 & NA & NA & NA & NA & NA & $5.37 \mathrm{E}-05$ & NA & NA & NA \\
\hline
\end{tabular}


Table T18 (continued).

\begin{tabular}{|c|c|c|c|c|c|c|c|c|c|c|}
\hline \multirow[b]{4}{*}{$\begin{array}{l}\text { Core, section, } \\
\text { interval }(\mathrm{cm})\end{array}$} & \multirow[b]{4}{*}{$\begin{array}{l}\text { Depth } \\
\text { CSF }(m)\end{array}$} & \multicolumn{5}{|c|}{ PCA } & \multirow[b]{4}{*}{$\begin{array}{c}\text { NRM } 20 \mathrm{mT} \\
(\mathrm{A} / \mathrm{m})\end{array}$} & \multirow{3}{*}{\multicolumn{3}{|c|}{$\begin{array}{c}\text { Archive-half section at } 20 \mathrm{mT} \text { AF } \\
\text { demagnetization }\end{array}$}} \\
\hline & & \multicolumn{2}{|c|}{ Declination } & \multirow[b]{3}{*}{$\begin{array}{c}\text { Inclination } \\
\left(^{\circ}\right)\end{array}$} & \multirow[b]{3}{*}{$\begin{array}{c}\text { MAD } \\
\left({ }^{\circ}\right)\end{array}$} & \multirow[b]{3}{*}{$\begin{array}{c}\text { Range } \\
(\mathrm{mT})\end{array}$} & & & & \\
\hline & & & Geographical & & & & & & & \\
\hline & & $\begin{array}{l}\text { Azimuthally } \\
\text { unoriented }\left({ }^{\circ}\right)\end{array}$ & $\begin{array}{l}\text { coordinates } \\
\left(0^{\circ}-360^{\circ}\right)\end{array}$ & & & & & $\begin{array}{c}\text { Declination } \\
\left({ }^{\circ}\right)\end{array}$ & $\begin{array}{c}\text { Inclination } \\
\left({ }^{\circ}\right)\end{array}$ & $\begin{array}{l}\text { NRM } \\
(\mathrm{A} / \mathrm{m})\end{array}$ \\
\hline $38 X-3,88$ & 354.97 & NA & NA & NA & NA & NA & $1.37 \mathrm{E}-04$ & NA & NA & NA \\
\hline $39 X-3,94$ & 364.65 & NA & NA & NA & NA & NA & $1.92 \mathrm{E}-04$ & NA & NA & NA \\
\hline $40 X-3,90$ & 374.10 & 5.0 & NA & -8.2 & 17.6 & $15-40$ & $6.93 \mathrm{E}-05$ & NA & NA & NA \\
\hline $41 X-3,90$ & 383.60 & NA & NA & NA & NA & NA & $9.61 \mathrm{E}-05$ & NA & NA & NA \\
\hline $42 X-3,69$ & 392.89 & NA & NA & NA & NA & NA & $4.71 \mathrm{E}-05$ & NA & NA & NA \\
\hline $43 X-4,127$ & 404.57 & NA & NA & NA & NA & NA & $2.99 \mathrm{E}-04$ & NA & NA & NA \\
\hline $44 X-2,85$ & 410.75 & NA & NA & NA & NA & NA & $1.24 \mathrm{E}-04$ & NA & NA & NA \\
\hline
\end{tabular}

Notes: $\mathrm{MAD}=$ maximum angular deviation, $\mathrm{NRM}=$ natural remanence magnetism. $\mathrm{NA}=$ not applicable. 
Table T19. Magnetic susceptibility of discrete samples, Hole U1335A. (See table notes.) (Continued on next five pages.)

\begin{tabular}{|c|c|c|c|c|c|c|c|c|c|c|c|}
\hline \multirow[b]{2}{*}{$\begin{array}{l}\text { Core, section, } \\
\text { interval }(\mathrm{cm})\end{array}$} & \multirow[b]{2}{*}{$\begin{array}{c}\text { Depth } \\
\text { CSF }(m)\end{array}$} & \multirow[b]{2}{*}{ LIMS ID } & \multicolumn{2}{|c|}{ Susceptibility } & \multirow[b]{2}{*}{$\begin{array}{l}\text { Total mass } \\
(\mathrm{g})\end{array}$} & \multirow{2}{*}{$\begin{array}{c}\text { Bulk } \\
\text { density } \\
\left(\mathrm{g} / \mathrm{cm}^{3}\right)\end{array}$} & \multirow[b]{2}{*}{$\begin{array}{l}\text { Volume } \\
\left(\mathrm{cm}^{3}\right)\end{array}$} & \multicolumn{3}{|c|}{ Susceptibility } & \multirow[b]{2}{*}{ Scale factor } \\
\hline & & & $\begin{array}{l}\text { Raw } \\
\left(10^{-6}\right)\end{array}$ & $\begin{array}{c}\text { Corrected } \\
\left(10^{-6}\right)\end{array}$ & & & & $\begin{array}{c}\text { Volume normalized } \\
\left(10^{-5}\right)\end{array}$ & $\begin{array}{c}\text { Mass normalized } \\
\left(\mathrm{m}^{3} / \mathrm{kg}\right)\end{array}$ & $\begin{array}{l}\text { Whole core } \\
\text { (raw values) }\end{array}$ & \\
\hline \multicolumn{12}{|l|}{ 320-U1335A- } \\
\hline $1 \mathrm{H}-1,94-96$ & 0.95 & CUBE716101 & 69.5 & 74.4 & 12.14 & 1.30 & 5.81 & 8.97 & $4.288 \mathrm{E}-08$ & 7.62 & $1.18 \mathrm{E}+00$ \\
\hline $1 \mathrm{H}-2,89-91$ & 2.40 & CUBE716111 & 83.5 & 88.4 & 10.88 & 1.31 & 4.79 & 12.92 & 5.687E-08 & 10.68 & $1.21 \mathrm{E}+00$ \\
\hline $1 \mathrm{H}-3,84-86$ & 3.85 & CUBE716121 & 22.8 & 27.7 & 13.78 & 1.33 & 6.91 & 2.80 & $1.405 \mathrm{E}-08$ & 7.93 & $3.53 \mathrm{E}-01$ \\
\hline $1 \mathrm{H}-4,84-86$ & 5.35 & CUBE716131 & 96.6 & 101.5 & 12.55 & 1.35 & 5.91 & 12.03 & $5.660 \mathrm{E}-08$ & 10.66 & $1.13 \mathrm{E}+00$ \\
\hline $1 \mathrm{H}-5,84-86$ & 6.85 & CUBE716141 & 51.3 & 56.2 & 14.17 & 1.37 & 6.99 & 5.63 & $2.778 \mathrm{E}-08$ & 9.88 & $5.70 \mathrm{E}-01$ \\
\hline $1 \mathrm{H}-6,84-86$ & 8.05 & CUBE716151 & 74.3 & 79.2 & 13.36 & 1.38 & 6.36 & 8.71 & $4.148 \mathrm{E}-08$ & 9.94 & $8.76 \mathrm{E}-01$ \\
\hline $2 \mathrm{H}-1,84-86$ & 9.75 & CUBE717291 & 106.1 & 111.0 & 12.20 & 1.26 & 6.05 & 12.85 & $6.369 \mathrm{E}-08$ & 13.06 & $9.84 \mathrm{E}-01$ \\
\hline $2 \mathrm{H}-2,84-86$ & 11.25 & CUBE717301 & 69.5 & 74.4 & 12.93 & 1.24 & 6.70 & 7.77 & $4.026 \mathrm{E}-08$ & 11.04 & $7.04 \mathrm{E}-01$ \\
\hline $2 \mathrm{H}-3,84-86$ & 12.75 & CUBE717311 & 34.3 & 39.2 & 14.26 & 1.40 & 6.90 & 3.97 & $1.924 \mathrm{E}-08$ & 8.68 & $4.58 \mathrm{E}-01$ \\
\hline $2 \mathrm{H}-4,94-96$ & 14.35 & CUBE717321 & 44.6 & 49.5 & 12.88 & 1.51 & 5.51 & 6.30 & $2.691 \mathrm{E}-08$ & 8.82 & 7.14E-01 \\
\hline $2 \mathrm{H}-5,84-86$ & 15.75 & CUBE717331 & 51.1 & 56.0 & 10.32 & 1.37 & 4.19 & 9.36 & $3.796 \mathrm{E}-08$ & 13.20 & $7.09 \mathrm{E}-01$ \\
\hline $2 \mathrm{H}-6,84-86$ & 17.25 & CUBE717341 & 33.8 & 38.7 & 12.50 & 1.27 & 6.23 & 4.35 & $2.168 \mathrm{E}-08$ & 8.86 & $4.91 \mathrm{E}-01$ \\
\hline $2 \mathrm{H}-7,49-51$ & 18.40 & CUBE717351 & 70.2 & 75.1 & 11.92 & 1.25 & 5.89 & 8.94 & $4.412 \mathrm{E}-08$ & 9.47 & $9.43 \mathrm{E}-01$ \\
\hline $3 \mathrm{H}-1,84-86$ & 19.25 & CUBE720851 & 76.3 & 81.2 & 12.37 & 1.19 & 6.55 & 8.68 & $4.596 \mathrm{E}-08$ & 12.67 & $6.85 \mathrm{E}-01$ \\
\hline $3 \mathrm{H}-2,84-86$ & 20.75 & CUBE720861 & 89.5 & 94.4 & 12.46 & 1.26 & 6.22 & 10.61 & $5.301 \mathrm{E}-08$ & 14.03 & $7.56 \mathrm{E}-01$ \\
\hline $3 \mathrm{H}-3,84-86$ & 22.25 & CUBE720871 & 109.8 & 114.7 & 12.15 & 1.34 & 5.63 & 14.27 & $6.608 \mathrm{E}-08$ & 18.20 & $7.84 \mathrm{E}-01$ \\
\hline $3 \mathrm{H}-4,84-86$ & 23.75 & CUBE720881 & 96.2 & 101.1 & 12.39 & 1.27 & 6.14 & 11.52 & $5.712 \mathrm{E}-08$ & 15.37 & $7.50 \mathrm{E}-01$ \\
\hline $3 \mathrm{H}-5,84-86$ & 25.25 & CUBE720891 & 115.7 & 120.6 & 12.42 & 1.29 & 6.05 & 13.96 & $6.797 \mathrm{E}-08$ & 15.29 & $9.13 \mathrm{E}-01$ \\
\hline $3 \mathrm{H}-6,84-86$ & 26.75 & CUBE720901 & 88.6 & 93.5 & 12.80 & 1.33 & 6.15 & 10.65 & $5.115 \mathrm{E}-08$ & 11.85 & $8.98 \mathrm{E}-01$ \\
\hline $4 \mathrm{H}-2,84-86$ & 30.25 & CUBE722191 & 116.1 & 121.0 & 12.17 & 1.29 & 5.88 & 14.40 & $6.960 \mathrm{E}-08$ & 17.35 & $8.30 \mathrm{E}-01$ \\
\hline $4 \mathrm{H}-3,84-86$ & 31.75 & CUBE722211 & 106.7 & 111.6 & 12.78 & 1.42 & 5.78 & 13.53 & $6.113 \mathrm{E}-08$ & 13.81 & $9.80 \mathrm{E}-01$ \\
\hline $4 \mathrm{H}-4,84-86$ & 33.25 & CUBE722221 & 44.8 & 49.7 & 13.46 & 1.51 & 5.87 & 5.93 & $2.583 \mathrm{E}-08$ & 11.73 & $5.05 \mathrm{E}-01$ \\
\hline $4 \mathrm{H}-5,84-86$ & 34.75 & CUBE722231 & 87.4 & 92.3 & 12.44 & 1.40 & 5.60 & 11.53 & $5.191 \mathrm{E}-08$ & 12.92 & $8.93 \mathrm{E}-01$ \\
\hline $4 \mathrm{H}-6,84-86$ & 36.25 & CUBE722241 & 97.3 & 102.2 & 12.81 & 1.34 & 6.15 & 11.62 & $5.582 \mathrm{E}-08$ & 14.14 & $8.22 \mathrm{E}-01$ \\
\hline $4 \mathrm{H}-7,59-61$ & 37.50 & CUBE722201 & 88.0 & 92.9 & 12.47 & 1.39 & 5.65 & 11.52 & 5.217E-08 & 12.01 & $9.59 \mathrm{E}-01$ \\
\hline $5 \mathrm{H}-1,109-111$ & 38.50 & CUBE722951 & 17.1 & 22.0 & 13.94 & 1.68 & 5.57 & 2.76 & $1.104 \mathrm{E}-08$ & 2.69 & $1.03 \mathrm{E}+00$ \\
\hline $5 \mathrm{H}-2,109-111$ & 40.00 & CUBE722991 & 12.1 & 17.0 & 14.33 & 1.59 & 6.14 & 1.94 & $8.309 \mathrm{E}-09$ & 3.02 & $6.42 \mathrm{E}-01$ \\
\hline $5 \mathrm{H}-3,109-111$ & 41.50 & CUBE723001 & 63.9 & 68.8 & 13.14 & 1.42 & 6.02 & 7.99 & $3.663 \mathrm{E}-08$ & 9.05 & $8.83 \mathrm{E}-01$ \\
\hline $5 \mathrm{H}-4,84-86$ & 42.75 & CUBE722961 & 53.7 & 58.6 & 13.11 & 1.41 & 6.05 & 6.78 & $3.127 \mathrm{E}-08$ & 9.46 & $7.16 \mathrm{E}-01$ \\
\hline $5 \mathrm{H}-5,84-86$ & 44.25 & CUBE722971 & 48.8 & 53.7 & 13.61 & 1.51 & 5.97 & 6.29 & $2.759 \mathrm{E}-08$ & 5.67 & $1.11 \mathrm{E}+00$ \\
\hline $5 \mathrm{H}-6,84-86$ & 45.75 & CUBE722981 & 48.3 & 53.2 & 13.56 & 1.37 & 6.53 & 5.70 & $2.745 \mathrm{E}-08$ & 7.71 & $7.39 \mathrm{E}-01$ \\
\hline $6 \mathrm{H}-1,84-86$ & 47.75 & CUBE723831 & 21.7 & 26.6 & 13.33 & 1.54 & 5.67 & 3.28 & $1.394 \mathrm{E}-08$ & 5.41 & 6.07E-01 \\
\hline $6 \mathrm{H}-2,84-86$ & 49.25 & CUBE723841 & 19.2 & 24.1 & 13.13 & 1.55 & 5.50 & 3.07 & $1.285 \mathrm{E}-08$ & 3.27 & $9.38 \mathrm{E}-01$ \\
\hline $6 \mathrm{H}-3,84-86$ & 50.75 & CUBE723851 & -1.7 & 3.2 & 15.02 & 1.63 & 6.40 & 0.35 & 1.496E-09 & 0.98 & \\
\hline $6 \mathrm{H}-4,84-86$ & 52.25 & CUBE723861 & -2.6 & 2.3 & 11.64 & 1.55 & 4.54 & 0.35 & $1.361 \mathrm{E}-09$ & 0.88 & \\
\hline $6 \mathrm{H}-5,84-86$ & 53.75 & CUBE723871 & 3.1 & 8.0 & 13.80 & 1.51 & 6.08 & 0.92 & $4.042 \mathrm{E}-09$ & 1.04 & \\
\hline $6 \mathrm{H}-6,84-86$ & 55.25 & CUBE723881 & 2.1 & 7.0 & 13.33 & 1.35 & 6.47 & 0.76 & $3.684 \mathrm{E}-09$ & 2.33 & $3.26 \mathrm{E}-01$ \\
\hline $7 \mathrm{H}-1,84-86$ & 57.25 & CUBE724381 & 79.4 & 84.3 & 11.28 & 1.24 & 5.40 & 10.93 & $5.229 \mathrm{E}-08$ & 12.74 & $8.58 \mathrm{E}-01$ \\
\hline $7 \mathrm{H}-2,84-86$ & 58.75 & CUBE724391 & 143.9 & 148.8 & 12.40 & 1.21 & 6.43 & 16.19 & $8.400 \mathrm{E}-08$ & 19.29 & $8.39 \mathrm{E}-01$ \\
\hline $7 \mathrm{H}-3,84-86$ & 60.25 & CUBE724401 & 140.0 & 144.9 & 12.28 & 1.28 & 6.01 & 16.88 & $8.260 \mathrm{E}-08$ & 20.77 & $8.13 \mathrm{E}-01$ \\
\hline $7 \mathrm{H}-4,84-86$ & 61.75 & CUBE724411 & 61.9 & 66.8 & 12.40 & 1.37 & 5.68 & 8.23 & $3.773 \mathrm{E}-08$ & 15.92 & 5.17E-01 \\
\hline $7 \mathrm{H}-5,84-86$ & 63.25 & CUBE724421 & 121.4 & 126.3 & 12.46 & 1.28 & 6.15 & 14.38 & 7.096E-08 & 19.07 & $7.54 \mathrm{E}-01$ \\
\hline $7 \mathrm{H}-6,84-86$ & 64.75 & CUBE724431 & 41.3 & 46.2 & 13.20 & 1.54 & 5.59 & 5.78 & $2.449 \mathrm{E}-08$ & 12.30 & $4.70 \mathrm{E}-01$ \\
\hline 7H-7, 39-41 & 65.80 & CUBE724441 & 69.7 & 74.6 & 12.38 & 1.39 & 5.58 & 9.35 & 4.217E-08 & 11.41 & 8.19E-01 \\
\hline $8 \mathrm{H}-1,84-86$ & 66.75 & CUBE725011 & 49.4 & 54.3 & 13.02 & 1.46 & 5.78 & 6.57 & 2.917E-08 & 7.33 & $8.96 \mathrm{E}-01$ \\
\hline $8 \mathrm{H}-2,84-86$ & 68.25 & CUBE725021 & 1.6 & 6.5 & 13.90 & 1.64 & 5.68 & 0.80 & $3.252 \mathrm{E}-09$ & 2.46 & $3.24 \mathrm{E}-01$ \\
\hline $8 \mathrm{H}-3,84-86$ & 69.75 & CUBE725031 & -9.8 & -4.9 & 14.18 & 1.66 & 5.79 & -0.60 & $-2.434 \mathrm{E}-09$ & 0.43 & \\
\hline $8 \mathrm{H}-4,84-86$ & 71.25 & CUBE725041 & -7.6 & -2.7 & 13.10 & 1.60 & 5.30 & -0.36 & $-1.464 \mathrm{E}-09$ & 0.82 & \\
\hline $8 \mathrm{H}-5,84-86$ & 72.75 & CUBE725051 & 13.6 & 18.5 & 12.88 & 1.59 & 5.20 & 2.49 & $1.006 \mathrm{E}-08$ & 3.79 & $6.57 \mathrm{E}-01$ \\
\hline
\end{tabular}


Table T19 (continued). (Continued on next page.)

\begin{tabular}{|c|c|c|c|c|c|c|c|c|c|c|c|}
\hline \multirow[b]{2}{*}{$\begin{array}{l}\text { Core, section, } \\
\text { interval }(\mathrm{cm})\end{array}$} & \multirow[b]{2}{*}{$\begin{array}{l}\text { Depth } \\
\text { CSF (m) }\end{array}$} & \multirow[b]{2}{*}{ LIMS ID } & \multicolumn{2}{|c|}{ Susceptibility } & \multirow[b]{2}{*}{$\begin{array}{l}\text { Total mass } \\
\text { (g) }\end{array}$} & \multirow{2}{*}{$\begin{array}{c}\text { Bulk } \\
\text { density } \\
\left(\mathrm{g} / \mathrm{cm}^{3}\right)\end{array}$} & \multirow[b]{2}{*}{$\begin{array}{l}\text { Volume } \\
\left(\mathrm{cm}^{3}\right)\end{array}$} & \multicolumn{3}{|c|}{ Susceptibility } & \multirow[b]{2}{*}{ Scale factor } \\
\hline & & & $\begin{array}{l}\text { Raw } \\
\left(10^{-6}\right)\end{array}$ & $\begin{array}{c}\text { Corrected } \\
\left(10^{-6}\right)\end{array}$ & & & & $\begin{array}{l}\text { Volume normalized } \\
\qquad\left(10^{-5}\right)\end{array}$ & $\begin{array}{l}\text { Mass normalized } \\
\left(\mathrm{m}^{3} / \mathrm{kg}\right)\end{array}$ & $\begin{array}{l}\text { Whole core } \\
\text { (raw values) }\end{array}$ & \\
\hline $8 \mathrm{H}-6,84-86$ & 74.25 & CUBE725061 & -6.0 & -1.1 & 13.41 & 1.55 & 5.68 & -0.14 & $-5.888 \mathrm{E}-10$ & 1.38 & \\
\hline $8 \mathrm{H}-7,49-51$ & 75.40 & CUBE725071 & -5.6 & -0.7 & 14.16 & 1.56 & 6.12 & -0.08 & $-3.470 \mathrm{E}-10$ & 0.85 & \\
\hline $9 \mathrm{H}-1,84-86$ & 76.25 & CUBE726251 & -5.3 & -0.4 & 13.89 & 1.64 & 5.65 & -0.04 & $-1.814 \mathrm{E}-10$ & -0.05 & \\
\hline $9 \mathrm{H}-2,84-86$ & 77.75 & CUBE726261 & -5.7 & -0.8 & 14.39 & 1.66 & 5.89 & -0.09 & $-3.663 \mathrm{E}-10$ & 0.60 & \\
\hline $9 \mathrm{H}-3,84-86$ & 79.25 & CUBE726271 & -0.1 & 4.8 & 14.09 & 1.62 & 5.87 & 0.57 & $2.388 \mathrm{E}-09$ & 1.36 & \\
\hline $9 \mathrm{H}-4,84-86$ & 80.75 & CUBE726281 & 2.7 & 7.6 & 12.37 & 1.64 & 4.73 & 1.13 & $4.308 \mathrm{E}-09$ & 1.68 & \\
\hline $9 \mathrm{H}-5,84-86$ & 82.25 & CUBE726291 & -4.0 & 0.9 & 13.64 & 1.53 & 5.92 & 0.11 & $4.588 \mathrm{E}-10$ & 0.34 & \\
\hline $9 \mathrm{H}-6,84-86$ & 83.75 & CUBE726301 & -5.6 & -0.7 & 13.12 & 1.67 & 5.12 & -0.09 & $-3.505 \mathrm{E}-10$ & -0.27 & \\
\hline $10 \mathrm{H}-1,84-86$ & 85.75 & CUBE727371 & -7.7 & -2.8 & 11.36 & 1.65 & 4.11 & -0.48 & $-1.746 \mathrm{E}-09$ & -0.76 & \\
\hline $10 \mathrm{H}-2,84-86$ & 87.25 & CUBE727381 & -10.1 & -5.2 & 13.65 & 1.69 & 5.37 & -0.68 & $-2.667 \mathrm{E}-09$ & -0.98 & \\
\hline $10 \mathrm{H}-3,84-86$ & 88.75 & CUBE727391 & -9.7 & -4.8 & 13.07 & 1.77 & 4.79 & -0.71 & $-2.590 \mathrm{E}-09$ & -1.05 & \\
\hline $10 \mathrm{H}-4,84-86$ & 90.25 & CUBE727401 & -11.6 & -6.7 & 14.30 & 1.66 & 5.87 & -0.80 & $-3.285 \mathrm{E}-09$ & -0.88 & \\
\hline $10 \mathrm{H}-5,84-86$ & 91.75 & CUBE727411 & -9.0 & -4.1 & 12.70 & 1.65 & 4.92 & -0.59 & $-2.269 \mathrm{E}-09$ & -0.92 & \\
\hline $10 \mathrm{H}-6,84-86$ & 93.25 & CUBE727421 & -7.9 & -3.0 & 9.92 & 1.72 & 3.11 & -0.67 & $-2.101 \mathrm{E}-09$ & -1.00 & \\
\hline $10 \mathrm{H}-7,74-76$ & 94.65 & CUBE727431 & -4.9 & -0.0 & 12.46 & 1.65 & 4.76 & -0.00 & $-1.854 \mathrm{E}-11$ & -0.97 & \\
\hline $11 \mathrm{H}-1,84-86$ & 95.25 & CUBE728351 & -6.0 & -1.1 & 12.58 & 1.65 & 4.86 & -0.16 & $-6.037 \mathrm{E}-10$ & -1.49 & \\
\hline $11 \mathrm{H}-2,84-86$ & 96.75 & CUBE728361 & -2.1 & 2.8 & 14.62 & 1.54 & 6.52 & 0.30 & $1.345 \mathrm{E}-09$ & -0.82 & \\
\hline $11 \mathrm{H}-3,84-86$ & 98.25 & CUBE728371 & -4.3 & 0.6 & 14.39 & 1.63 & 5.99 & 0.07 & $2.841 \mathrm{E}-10$ & -0.83 & \\
\hline $11 \mathrm{H}-4,84-86$ & 99.75 & CUBE728381 & -9.3 & -4.4 & 14.86 & 1.69 & 6.07 & -0.51 & $-2.066 \mathrm{E}-09$ & -1.24 & \\
\hline $11 \mathrm{H}-5,84-86$ & 101.25 & CUBE728391 & -7.9 & -3.0 & 13.78 & 1.63 & 5.63 & -0.38 & $-1.533 \mathrm{E}-09$ & -1.21 & \\
\hline $11 \mathrm{H}-6,84-86$ & 102.75 & CUBE728401 & -1.2 & 3.7 & 14.22 & 1.64 & 5.88 & 0.44 & $1.814 \mathrm{E}-09$ & -0.83 & \\
\hline $12 \mathrm{H}-1,84-86$ & 104.75 & CUBE729601 & -8.6 & -3.7 & 14.66 & 1.65 & 6.09 & -0.43 & $-1.767 \mathrm{E}-09$ & -0.93 & \\
\hline $12 \mathrm{H}-2,84-86$ & 106.25 & CUBE729611 & -6.8 & -1.9 & 13.39 & 1.62 & 5.42 & -0.24 & $-9.818 \mathrm{E}-10$ & -0.90 & \\
\hline $12 \mathrm{H}-3,84-86$ & 107.75 & CUBE729621 & -5.7 & -0.8 & 14.29 & 1.62 & 5.98 & -0.10 & $-4.076 \mathrm{E}-10$ & -0.63 & \\
\hline $12 \mathrm{H}-4,84-86$ & 109.25 & CUBE729631 & -3.2 & 1.7 & 13.69 & 1.58 & 5.77 & 0.21 & $8.713 \mathrm{E}-10$ & 0.14 & \\
\hline $12 \mathrm{H}-5,84-86$ & 110.75 & CUBE729641 & -5.1 & -0.2 & 14.74 & 1.71 & 5.95 & -0.02 & $-8.548 \mathrm{E}-11$ & 0.33 & \\
\hline $12 \mathrm{H}-6,59-61$ & 112.00 & CUBE729651 & -2.4 & 2.5 & 14.98 & 1.70 & 6.11 & 0.29 & $1.182 \mathrm{E}-09$ & -0.08 & \\
\hline $12 \mathrm{H}-7,59-61$ & 113.50 & CUBE729661 & 1.2 & 6.1 & 14.02 & 1.68 & 5.60 & 0.76 & $3.038 \mathrm{E}-09$ & 1.25 & \\
\hline $13 \mathrm{H}-1,104-106$ & 114.45 & CUBE730671 & 17.9 & 22.8 & 13.83 & 1.65 & 5.60 & 2.85 & $1.154 \mathrm{E}-08$ & 1.32 & \\
\hline $13 \mathrm{H}-2,84-86$ & 115.75 & CUBE730681 & 5.8 & 10.7 & 14.53 & 1.68 & 5.93 & 1.26 & $5.133 \mathrm{E}-09$ & 1.01 & \\
\hline $13 \mathrm{H}-3,84-86$ & 117.25 & CUBE730701 & 10.8 & 15.7 & 14.20 & 1.62 & 5.95 & 1.85 & $7.759 \mathrm{E}-09$ & 0.79 & \\
\hline $13 \mathrm{H}-4,84-86$ & 118.75 & CUBE730711 & -0.4 & 4.5 & 13.73 & 1.68 & 5.43 & 0.58 & $2.275 \mathrm{E}-09$ & 1.57 & \\
\hline $13 \mathrm{H}-5,84-86$ & 120.25 & CUBE730721 & 19.2 & 24.1 & 14.68 & 1.62 & 6.24 & 2.71 & $1.151 \mathrm{E}-08$ & 4.47 & $6.05 \mathrm{E}-01$ \\
\hline $13 \mathrm{H}-6,84-86$ & 121.75 & CUBE730731 & 12.2 & 17.1 & 14.71 & 1.66 & 6.08 & 1.97 & $8.156 \mathrm{E}-09$ & 1.79 & \\
\hline $13 \mathrm{H}-7,59-61$ & 123.00 & CUBE730691 & 8.2 & 13.1 & 13.72 & 1.69 & 5.40 & 1.70 & 6.697E-09 & 2.10 & $8.09 \mathrm{E}-01$ \\
\hline $14 \mathrm{H}-1,84-86$ & 123.75 & CUBE731601 & 2.6 & 7.5 & 14.19 & 1.74 & 5.51 & 0.95 & $3.681 \mathrm{E}-09$ & 0.43 & \\
\hline $14 \mathrm{H}-2,84-86$ & 125.25 & CUBE731611 & 35.1 & 40.0 & 13.11 & 1.53 & 5.55 & 5.04 & $2.135 \mathrm{E}-08$ & 2.85 & $1.77 \mathrm{E}+00$ \\
\hline $14 \mathrm{H}-3,84-86$ & 126.75 & CUBE731621 & 34.0 & 38.9 & 13.62 & 1.57 & 5.76 & 4.73 & $2.001 \mathrm{E}-08$ & 2.09 & $2.26 \mathrm{E}+00$ \\
\hline $14 \mathrm{H}-4,84-86$ & 128.25 & CUBE731631 & 34.4 & 39.3 & 13.97 & 1.65 & 5.69 & 4.83 & $1.969 \mathrm{E}-08$ & 3.29 & $1.47 \mathrm{E}+00$ \\
\hline $14 \mathrm{H}-5,84-86$ & 129.75 & CUBE731641 & 30.7 & 35.6 & 14.36 & 1.66 & 5.89 & 4.24 & $1.737 \mathrm{E}-08$ & 1.87 & \\
\hline $14 \mathrm{H}-6,84-86$ & 131.25 & CUBE731651 & 3.5 & 8.4 & 14.11 & 1.70 & 5.60 & 1.05 & $4.173 \mathrm{E}-09$ & 0.50 & \\
\hline $14 \mathrm{H}-7,69-71$ & 132.60 & CUBE731661 & 16.7 & 21.6 & 14.59 & 1.62 & 6.19 & 2.44 & $1.036 \mathrm{E}-08$ & 2.75 & $8.86 \mathrm{E}-01$ \\
\hline $15 \mathrm{H}-1,84-86$ & 133.25 & CUBE731781 & 17.8 & 22.7 & 14.40 & 1.62 & 6.04 & 2.63 & $1.102 \mathrm{E}-08$ & 3.85 & $6.82 \mathrm{E}-01$ \\
\hline $15 \mathrm{H}-2,74-76$ & 134.65 & CUBE731791 & 22.1 & 27.0 & 13.29 & 1.59 & 5.46 & 3.46 & $1.420 \mathrm{E}-08$ & 3.84 & $9.01 \mathrm{E}-01$ \\
\hline $15 \mathrm{H}-3,84-86$ & 135.75 & CUBE731801 & 0.6 & 5.5 & 12.81 & 1.64 & 5.01 & 0.77 & $2.993 \mathrm{E}-09$ & 1.27 & \\
\hline $15 \mathrm{H}-4,84-86$ & 137.25 & CUBE731811 & 12.8 & 17.7 & 14.77 & 1.69 & 6.03 & 2.05 & $8.374 \mathrm{E}-09$ & 3.72 & $5.52 \mathrm{E}-01$ \\
\hline $15 \mathrm{H}-5,84-86$ & 138.75 & CUBE731821 & 22.7 & 27.6 & 14.66 & 1.67 & 6.02 & 3.21 & $1.318 \mathrm{E}-08$ & 2.59 & $1.24 \mathrm{E}+00$ \\
\hline $15 \mathrm{H}-6,84-86$ & 140.25 & CUBE731831 & 34.8 & 39.7 & 14.46 & 1.64 & 6.03 & 4.61 & $1.924 \mathrm{E}-08$ & 3.79 & $1.22 \mathrm{E}+00$ \\
\hline $15 \mathrm{H}-7,49-51$ & 141.40 & CUBE731841 & 21.0 & 25.9 & 14.58 & 1.67 & 5.99 & 3.03 & $1.245 \mathrm{E}-08$ & 2.54 & $1.19 \mathrm{E}+00$ \\
\hline $16 \mathrm{H}-1,84-86$ & 142.75 & CUBE732281 & 72.6 & 77.5 & 14.42 & 1.64 & 5.99 & 9.06 & $3.762 \mathrm{E}-08$ & 4.75 & $1.91 \mathrm{E}+00$ \\
\hline
\end{tabular}


Table T19 (continued). (Continued on next page.)

\begin{tabular}{|c|c|c|c|c|c|c|c|c|c|c|c|}
\hline \multirow[b]{2}{*}{$\begin{array}{l}\text { Core, section, } \\
\text { interval }(\mathrm{cm})\end{array}$} & \multirow[b]{2}{*}{$\begin{array}{l}\text { Depth } \\
\text { CSF }(m)\end{array}$} & \multirow[b]{2}{*}{ LIMS ID } & \multicolumn{2}{|c|}{ Susceptibility } & \multirow[b]{2}{*}{$\begin{array}{l}\text { Total mass } \\
\text { (g) }\end{array}$} & \multirow{2}{*}{$\begin{array}{c}\text { Bulk } \\
\text { density } \\
\left(\mathrm{g} / \mathrm{cm}^{3}\right)\end{array}$} & \multirow[b]{2}{*}{$\begin{array}{l}\text { Volume } \\
\left(\mathrm{cm}^{3}\right)\end{array}$} & \multicolumn{3}{|c|}{ Susceptibility } & \multirow[b]{2}{*}{ Scale facto } \\
\hline & & & $\begin{array}{l}\text { Raw } \\
\left(10^{-6}\right)\end{array}$ & $\begin{array}{c}\text { Corrected } \\
\left(10^{-6}\right)\end{array}$ & & & & $\begin{array}{l}\text { Volume normalized } \\
\qquad\left(10^{-5}\right)\end{array}$ & $\begin{array}{c}\text { Mass normalized } \\
\left(\mathrm{m}^{3} / \mathrm{kg}\right)\end{array}$ & $\begin{array}{l}\text { Whole core } \\
\text { (raw values) }\end{array}$ & \\
\hline $16 \mathrm{H}-2,84-86$ & 144.25 & CUBE732291 & 5.5 & 10.4 & 14.07 & 1.69 & 5.62 & 1.30 & $5.193 \mathrm{E}-09$ & 0.69 & \\
\hline $16 \mathrm{H}-3,84-86$ & 145.75 & CUBE732301 & 56.4 & 61.3 & 13.62 & 1.50 & 6.00 & 7.15 & $3.150 \mathrm{E}-08$ & 5.18 & $1.38 \mathrm{E}+00$ \\
\hline $16 \mathrm{H}-4,84-86$ & 147.25 & CUBE732311 & 13.9 & 18.8 & 14.44 & 1.69 & 5.82 & 2.27 & $9.128 \mathrm{E}-09$ & 2.21 & $1.02 \mathrm{E}+00$ \\
\hline $16 \mathrm{H}-5,84-86$ & 148.75 & CUBE732321 & 14.2 & 19.1 & 14.42 & 1.73 & 5.69 & 2.35 & $9.272 \mathrm{E}-09$ & 2.81 & $8.36 \mathrm{E}-01$ \\
\hline $17 \mathrm{H}-1,84-86$ & 152.25 & CUBE732671 & 22.3 & 27.2 & 13.83 & 1.52 & 6.07 & 3.13 & $1.376 \mathrm{E}-08$ & 2.88 & $1.09 \mathrm{E}+00$ \\
\hline $17 \mathrm{H}-2,84-86$ & 153.75 & CUBE732701 & 5.5 & 10.4 & 14.78 & 1.64 & 6.20 & 1.18 & $4.936 \mathrm{E}-09$ & 0.91 & \\
\hline $17 \mathrm{H}-3,84-86$ & 155.25 & CUBE732711 & 5.3 & 10.2 & 14.70 & 1.69 & 6.00 & 1.20 & $4.879 \mathrm{E}-09$ & 1.90 & \\
\hline $17 \mathrm{H}-4,84-86$ & 156.75 & CUBE732721 & -6.2 & -1.3 & 14.40 & 1.64 & 5.99 & -0.15 & $-6.281 \mathrm{E}-10$ & 1.23 & \\
\hline $17 \mathrm{H}-5,84-86$ & 158.25 & CUBE732731 & 14.8 & 19.7 & 14.75 & 1.58 & 6.43 & 2.14 & $9.354 \mathrm{E}-09$ & 5.74 & $3.74 \mathrm{E}-01$ \\
\hline $17 \mathrm{H}-6,74-76$ & 159.65 & CUBE732681 & 95.9 & 100.8 & 14.03 & 1.47 & 6.40 & 11.02 & $5.030 \mathrm{E}-08$ & 8.73 & $1.26 \mathrm{E}+00$ \\
\hline $17 \mathrm{H}-7,49-51$ & 160.90 & CUBE732691 & 85.9 & 90.8 & 13.98 & 1.63 & 5.77 & 11.03 & $4.548 \mathrm{E}-08$ & 8.24 & $1.34 \mathrm{E}+00$ \\
\hline $18 \mathrm{H}-1,84-86$ & 161.75 & CUBE733251 & 18.3 & 23.2 & 12.43 & 1.60 & 4.90 & 3.31 & $1.304 \mathrm{E}-08$ & 5.87 & $5.63 \mathrm{E}-01$ \\
\hline $18 \mathrm{H}-2,84-86$ & 163.25 & CUBE733261 & 16.1 & 21.0 & 13.89 & 1.62 & 5.76 & 2.55 & 1.057E-08 & 4.53 & $5.63 \mathrm{E}-01$ \\
\hline $18 \mathrm{H}-3,84-86$ & 164.75 & CUBE733271 & 10.0 & 14.9 & 14.07 & 1.62 & 5.84 & 1.78 & 7.399E-09 & 3.48 & $5.12 \mathrm{E}-01$ \\
\hline $18 \mathrm{H}-4,84-86$ & 166.25 & CUBE733281 & 35.6 & 40.5 & 14.50 & 1.66 & 5.97 & 4.75 & $1.954 \mathrm{E}-08$ & 6.97 & $6.81 \mathrm{E}-01$ \\
\hline $18 \mathrm{H}-5,84-86$ & 167.75 & CUBE733291 & 26.6 & 31.5 & 14.32 & 1.66 & 5.88 & 3.75 & $1.541 \mathrm{E}-08$ & 4.19 & $8.95 \mathrm{E}-01$ \\
\hline $18 \mathrm{H}-6,84-86$ & 169.25 & CUBE733301 & 77.7 & 82.6 & 13.70 & 1.58 & 5.76 & 10.04 & $4.218 \mathrm{E}-08$ & 6.92 & $1.45 \mathrm{E}+00$ \\
\hline $19 \mathrm{H}-1,84-86$ & 171.25 & CUBE733691 & 26.3 & 31.2 & 14.42 & 1.68 & 5.83 & 3.74 & $1.514 \mathrm{E}-08$ & 9.69 & $3.86 \mathrm{E}-01$ \\
\hline $19 \mathrm{H}-2,84-86$ & 172.75 & CUBE733701 & 43.1 & 48.0 & 13.68 & 1.56 & 5.82 & 5.76 & $2.454 \mathrm{E}-08$ & 10.79 & $5.34 \mathrm{E}-01$ \\
\hline $19 \mathrm{H}-3,84-86$ & 174.25 & CUBE733711 & 54.7 & 59.6 & 14.04 & 1.58 & 5.98 & 6.97 & $2.971 \mathrm{E}-08$ & 10.61 & $6.58 \mathrm{E}-01$ \\
\hline $19 \mathrm{H}-4,84-86$ & 175.75 & CUBE733721 & 17.3 & 22.2 & 12.53 & 1.59 & 4.99 & 3.11 & $1.237 \mathrm{E}-08$ & 10.23 & $3.03 \mathrm{E}-01$ \\
\hline $19 \mathrm{H}-5,84-86$ & 177.25 & CUBE733731 & 46.4 & 51.3 & 14.37 & 1.54 & 6.33 & 5.67 & $2.500 \mathrm{E}-08$ & 10.25 & $5.53 \mathrm{E}-01$ \\
\hline $19 \mathrm{H}-6,84-86$ & 178.75 & CUBE733741 & 81.0 & 85.9 & 14.19 & 1.54 & 6.24 & 9.63 & $4.237 \mathrm{E}-08$ & 14.95 & $6.44 \mathrm{E}-01$ \\
\hline $19 \mathrm{H}-7,59-61$ & 180.00 & CUBE733751 & 56.7 & 61.6 & 14.21 & 1.49 & 6.44 & 6.70 & $3.035 \mathrm{E}-08$ & 8.48 & $7.89 \mathrm{E}-01$ \\
\hline $20 \mathrm{H}-1,84-86$ & 180.75 & CUBE734301 & 37.0 & 41.9 & 13.65 & 1.68 & 5.40 & 5.43 & $2.150 \mathrm{E}-08$ & 7.62 & 7.13E-01 \\
\hline $20 \mathrm{H}-2,84-86$ & 182.25 & CUBE734311 & 30.5 & 35.4 & 14.06 & 1.61 & 5.90 & 4.21 & 1.764E-08 & 6.37 & $6.60 \mathrm{E}-01$ \\
\hline $20 \mathrm{H}-3,84-86$ & 183.75 & CUBE734321 & 21.1 & 26.0 & 14.30 & 1.62 & 5.98 & 3.04 & $1.272 \mathrm{E}-08$ & 5.50 & $5.53 \mathrm{E}-01$ \\
\hline $20 \mathrm{H}-4,84-86$ & 185.25 & CUBE734331 & 9.7 & 14.6 & 13.70 & 1.68 & 5.41 & 1.89 & 7.478E-09 & 5.50 & $3.45 \mathrm{E}-01$ \\
\hline $20 \mathrm{H}-5,84-86$ & 186.75 & CUBE734341 & 27.1 & 32.0 & 14.10 & 1.60 & 5.92 & 3.78 & $1.590 \mathrm{E}-08$ & 7.91 & $4.78 \mathrm{E}-01$ \\
\hline $20 \mathrm{H}-6,84-86$ & 188.25 & CUBE734351 & 79.9 & 84.8 & 14.11 & 1.57 & 6.06 & 9.79 & 4.209E-08 & 10.54 & $9.29 \mathrm{E}-01$ \\
\hline $20 \mathrm{H}-7,59-61$ & 189.50 & CUBE734361 & 66.4 & 71.3 & 14.23 & 1.62 & 5.96 & 8.38 & 3.507E-08 & 10.13 & 8.27E-01 \\
\hline $21 \mathrm{H}-1,84-86$ & 190.25 & CUBE734901 & 19.7 & 24.6 & 14.80 & 1.68 & 6.07 & 2.83 & $1.162 \mathrm{E}-08$ & 4.42 & $6.41 \mathrm{E}-01$ \\
\hline $21 \mathrm{H}-2,84-86$ & 191.75 & CUBE734911 & 4.2 & 9.1 & 13.65 & 1.63 & 5.56 & 1.15 & $4.682 \mathrm{E}-09$ & 4.61 & $2.49 \mathrm{E}-01$ \\
\hline $21 \mathrm{H}-3,84-86$ & 193.25 & CUBE734921 & 41.8 & 46.7 & 15.09 & 1.65 & 6.37 & 5.14 & $2.167 \mathrm{E}-08$ & 7.76 & $6.62 \mathrm{E}-01$ \\
\hline $21 \mathrm{H}-4,84-86$ & 194.75 & CUBE734931 & 27.7 & 32.6 & 14.14 & 1.74 & 5.48 & 4.16 & $1.614 \mathrm{E}-08$ & 7.16 & $5.81 \mathrm{E}-01$ \\
\hline $21 \mathrm{H}-5,84-86$ & 196.25 & CUBE734941 & 16.0 & 20.9 & 14.51 & 1.75 & 5.68 & 2.57 & $1.006 \mathrm{E}-08$ & 4.34 & $5.91 \mathrm{E}-01$ \\
\hline $21 \mathrm{H}-6,94-96$ & 197.85 & CUBE734951 & 21.5 & 26.4 & 14.12 & 1.66 & 5.75 & 3.21 & 1.307E-08 & 5.82 & $5.52 \mathrm{E}-01$ \\
\hline $22 \mathrm{H}-1,119-121$ & 200.10 & CUBE735481 & 11.9 & 16.8 & 13.03 & 1.53 & 5.53 & 2.12 & $9.015 \mathrm{E}-09$ & 3.62 & $5.86 \mathrm{E}-01$ \\
\hline $22 \mathrm{H}-2,84-86$ & 201.25 & CUBE735531 & 9.3 & 14.2 & 13.31 & 1.67 & 5.21 & 1.91 & 7.455E-09 & 2.73 & $6.97 \mathrm{E}-01$ \\
\hline $22 \mathrm{H}-3,84-86$ & 202.75 & CUBE735471 & 8.9 & 13.8 & 13.73 & 1.64 & 5.56 & 1.74 & 7.047E-09 & 3.23 & $5.39 \mathrm{E}-01$ \\
\hline $22 \mathrm{H}-4,84-86$ & 204.25 & CUBE735491 & 16.3 & 21.2 & 13.51 & 1.57 & 5.68 & 2.61 & $1.097 \mathrm{E}-08$ & 2.15 & $1.21 \mathrm{E}+00$ \\
\hline $22 \mathrm{H}-5,84-86$ & 205.75 & CUBE735501 & -0.8 & 4.1 & 14.56 & 1.71 & 5.84 & 0.50 & $1.992 \mathrm{E}-09$ & 0.62 & \\
\hline $22 \mathrm{H}-6,84-86$ & 207.25 & CUBE735511 & 6.3 & 11.2 & 14.09 & 1.65 & 5.74 & 1.37 & $5.578 \mathrm{E}-09$ & 1.51 & \\
\hline $22 \mathrm{H}-7,49-51$ & 208.40 & CUBE735521 & 1.9 & 6.8 & 14.53 & 1.62 & 6.12 & 0.78 & $3.298 \mathrm{E}-09$ & 1.14 & \\
\hline $23 \mathrm{H}-2,89-91$ & 210.80 & CUBE736691 & -4.8 & 0.1 & 13.43 & 1.70 & 5.21 & 0.01 & 3.909E-11 & 2.40 & $4.20 \mathrm{E}-03$ \\
\hline $23 \mathrm{H}-3,84-86$ & 212.25 & CUBE736701 & -5.7 & -0.8 & 13.81 & 1.69 & 5.47 & -0.11 & $-4.283 \mathrm{E}-10$ & 1.37 & \\
\hline $23 \mathrm{H}-4,84-86$ & 213.75 & CUBE736711 & 6.2 & 11.1 & 14.63 & 1.69 & 5.95 & 1.30 & $5.294 \mathrm{E}-09$ & 3.28 & 3.97E-01 \\
\hline $23 \mathrm{H}-5,84-86$ & 215.25 & CUBE736721 & -2.1 & 2.8 & 14.76 & 1.79 & 5.68 & 0.35 & $1.338 \mathrm{E}-09$ & 2.41 & $1.44 \mathrm{E}-01$ \\
\hline $23 \mathrm{H}-6,84-86$ & 216.75 & CUBE736731 & 2.1 & 7.0 & 13.87 & 1.71 & 5.43 & 0.90 & $3.530 \mathrm{E}-09$ & 2.16 & $4.18 \mathrm{E}-01$ \\
\hline $23 \mathrm{H}-7,39-41$ & 217.80 & CUBE736741 & 2.5 & 7.4 & 14.66 & 1.75 & 5.75 & 0.90 & $3.516 \mathrm{E}-09$ & 1.36 & \\
\hline
\end{tabular}


Table T19 (continued). (Continued on next page.)

\begin{tabular}{|c|c|c|c|c|c|c|c|c|c|c|c|}
\hline \multirow[b]{2}{*}{$\begin{array}{l}\text { Core, section, } \\
\text { interval }(\mathrm{cm})\end{array}$} & \multirow[b]{2}{*}{$\begin{array}{l}\text { Depth } \\
\text { CSF (m) }\end{array}$} & \multirow[b]{2}{*}{ LIMS ID } & \multicolumn{2}{|c|}{ Susceptibility } & \multirow[b]{2}{*}{$\begin{array}{l}\text { Total mass } \\
\quad(\mathrm{g})\end{array}$} & \multirow{2}{*}{$\begin{array}{c}\text { Bulk } \\
\text { density } \\
\left(\mathrm{g} / \mathrm{cm}^{3}\right)\end{array}$} & \multirow[b]{2}{*}{$\begin{array}{l}\text { Volume } \\
\left(\mathrm{cm}^{3}\right)\end{array}$} & \multicolumn{3}{|c|}{ Susceptibility } & \multirow[b]{2}{*}{ Scale factor } \\
\hline & & & $\begin{array}{l}\text { Raw } \\
\left(10^{-6}\right)\end{array}$ & $\begin{array}{c}\text { Corrected } \\
\left(10^{-6}\right)\end{array}$ & & & & $\begin{array}{c}\text { Volume normalized } \\
\qquad\left(10^{-5}\right)\end{array}$ & $\begin{array}{l}\text { Mass normalized } \\
\left(\mathrm{m}^{3} / \mathrm{kg}\right)\end{array}$ & $\begin{array}{l}\text { Whole core } \\
\text { (raw values) }\end{array}$ & \\
\hline $24 \mathrm{H}-1,84-86$ & 218.75 & CUBE738071 & 0.6 & 5.5 & 14.71 & 1.78 & 5.70 & 0.67 & $2.598 \mathrm{E}-09$ & -0.33 & \\
\hline $24 \mathrm{H}-2,84-86$ & 220.25 & CUBE738091 & -0.6 & 4.3 & 14.02 & 1.60 & 5.88 & 0.51 & $2.141 \mathrm{E}-09$ & -0.34 & \\
\hline $24 \mathrm{H}-3,84-86$ & 221.75 & CUBE738101 & -2.3 & 2.6 & 13.47 & 1.74 & 5.09 & 0.35 & $1.328 \mathrm{E}-09$ & -0.52 & \\
\hline $24 \mathrm{H}-4,84-86$ & 223.25 & CUBE738111 & -8.9 & -4.0 & 14.54 & 1.81 & 5.48 & -0.51 & $-1.913 \mathrm{E}-09$ & -0.55 & \\
\hline $24 \mathrm{H}-5,84-86$ & 224.75 & CUBE738121 & -5.9 & -1.0 & 14.54 & 1.76 & 5.65 & -0.12 & $-4.829 \mathrm{E}-10$ & -0.79 & \\
\hline $24 \mathrm{H}-6,84-86$ & 226.25 & CUBE738131 & -5.0 & -0.1 & 14.77 & 1.73 & 5.90 & -0.02 & $-7.014 \mathrm{E}-11$ & -0.55 & \\
\hline $24 \mathrm{H}-7,59-61$ & 227.50 & CUBE738081 & -5.8 & -0.9 & 13.86 & 1.73 & 5.35 & -0.11 & $-4.323 \mathrm{E}-10$ & -1.01 & \\
\hline $25 \mathrm{H}-1,84-86$ & 228.25 & CUBE738751 & -7.1 & -2.2 & 15.19 & 1.72 & 6.16 & -0.24 & $-9.935 E-10$ & -1.64 & \\
\hline $25 \mathrm{H}-2,84-86$ & 229.75 & CUBE738771 & -6.7 & -1.8 & 13.64 & 1.73 & 5.23 & -0.25 & $-9.412 \mathrm{E}-10$ & -1.67 & \\
\hline $25 \mathrm{H}-3,84-86$ & 231.25 & CUBE738781 & -7.8 & -2.9 & 14.47 & 1.71 & 5.76 & -0.35 & $-1.393 \mathrm{E}-09$ & -1.83 & \\
\hline $25 \mathrm{H}-4,84-86$ & 232.75 & CUBE738791 & -8.0 & -3.1 & 13.86 & 1.71 & 5.43 & -0.39 & $-1.540 \mathrm{E}-09$ & -1.89 & \\
\hline $25 \mathrm{H}-5,84-86$ & 234.25 & CUBE738801 & -8.1 & -3.2 & 13.68 & 1.71 & 5.32 & -0.42 & $-1.635 E-09$ & -1.19 & \\
\hline $25 \mathrm{H}-6,84-86$ & 235.75 & CUBE738811 & -8.7 & -3.8 & 14.35 & 1.59 & 6.15 & -0.43 & $-1.840 \mathrm{E}-09$ & -1.34 & \\
\hline $25 \mathrm{H}-7,34-36$ & 236.75 & CUBE738761 & -9.7 & -4.8 & 13.37 & 1.56 & 5.64 & -0.59 & $-2.511 \mathrm{E}-09$ & -0.98 & \\
\hline $26 \mathrm{H}-1,84-86$ & 237.75 & CUBE739761 & -8.4 & -3.5 & 14.72 & 1.57 & 6.45 & -0.38 & $-1.669 \mathrm{E}-09$ & -0.91 & \\
\hline $26 \mathrm{H}-2,84-86$ & 239.25 & CUBE739781 & -6.6 & -1.7 & 13.99 & 1.72 & 5.47 & -0.22 & $-8.416 \mathrm{E}-10$ & -1.02 & \\
\hline $26 \mathrm{H}-3,84-86$ & 240.75 & CUBE739791 & -7.1 & -2.2 & 13.88 & 1.69 & 5.48 & -0.28 & $-1.105 \mathrm{E}-09$ & -0.95 & \\
\hline $26 \mathrm{H}-4,84-86$ & 242.25 & CUBE739801 & -6.1 & -1.2 & 13.70 & 1.71 & 5.34 & -0.16 & $-6.254 \mathrm{E}-10$ & -0.15 & \\
\hline $26 \mathrm{H}-5,84-86$ & 243.75 & CUBE739811 & -2.2 & 2.7 & 14.65 & 1.77 & 5.70 & 0.33 & $1.281 \mathrm{E}-09$ & 0.16 & \\
\hline $26 \mathrm{H}-6,84-86$ & 245.25 & CUBE739821 & 3.4 & 8.3 & 14.35 & 1.72 & 5.68 & 1.02 & $4.029 \mathrm{E}-09$ & 1.42 & \\
\hline $26 \mathrm{H}-7,64-66$ & 246.55 & CUBE739771 & 7.3 & 12.2 & 14.34 & 1.69 & 5.78 & 1.47 & $5.946 \mathrm{E}-09$ & 0.10 & \\
\hline $27 \mathrm{H}-1,84-86$ & 247.25 & CUBE740511 & -2.9 & 2.0 & 14.64 & 1.72 & 5.85 & 0.24 & $9.563 \mathrm{E}-10$ & -1.51 & \\
\hline $27 \mathrm{H}-2,84-86$ & 248.75 & CUBE740521 & -0.4 & 4.5 & 14.36 & 1.71 & 5.72 & 0.55 & $2.198 \mathrm{E}-09$ & -0.16 & \\
\hline $27 \mathrm{H}-3,84-86$ & 250.25 & CUBE740531 & 0.1 & 5.0 & 14.44 & 1.72 & 5.71 & 0.61 & $2.430 \mathrm{E}-09$ & -0.68 & \\
\hline $27 \mathrm{H}-4,84-86$ & 251.75 & CUBE740541 & -1.8 & 3.1 & 14.26 & 1.75 & 5.52 & 0.39 & $1.524 \mathrm{E}-09$ & -0.92 & \\
\hline $27 \mathrm{H}-5,84-86$ & 253.25 & CUBE740551 & -0.4 & 4.5 & 15.72 & 1.73 & 6.42 & 0.49 & 2.017E-09 & -0.69 & \\
\hline $27 \mathrm{H}-6,84-86$ & 254.75 & CUBE740561 & 6.1 & 11.0 & 14.50 & 1.73 & 5.71 & 1.35 & $5.330 \mathrm{E}-09$ & -0.03 & \\
\hline $28 \mathrm{H}-1,84-86$ & 256.75 & CUBE741121 & 5.8 & 10.7 & 14.80 & 1.71 & 5.97 & 1.25 & $5.045 \mathrm{E}-09$ & 1.47 & \\
\hline $28 \mathrm{H}-2,84-86$ & 258.25 & CUBE741141 & 3.8 & 8.7 & 14.57 & 1.70 & 5.87 & 1.03 & $4.163 \mathrm{E}-09$ & 1.21 & \\
\hline $28 \mathrm{H}-3,84-86$ & 259.75 & CUBE741151 & 1.6 & 6.5 & 14.96 & 1.70 & 6.11 & 0.74 & $3.025 \mathrm{E}-09$ & 0.83 & \\
\hline $28 \mathrm{H}-4,84-86$ & 261.25 & CUBE741161 & 3.4 & 8.3 & 15.11 & 1.78 & 5.90 & 0.99 & $3.850 \mathrm{E}-09$ & 0.71 & \\
\hline $28 \mathrm{H}-5,84-86$ & 262.75 & CUBE741171 & 1.5 & 6.4 & 15.33 & 1.76 & 6.10 & 0.74 & $2.924 \mathrm{E}-09$ & 0.43 & \\
\hline $28 \mathrm{H}-6,84-86$ & 264.25 & CUBE741181 & -3.0 & 1.9 & 14.39 & 1.84 & 5.33 & 0.25 & $9.150 \mathrm{E}-10$ & -0.72 & \\
\hline $28 \mathrm{H}-7,59-61$ & 265.50 & CUBE741131 & -4.0 & 0.9 & 13.90 & 1.79 & 5.19 & 0.12 & 4.563E-10 & -0.33 & \\
\hline $29 \mathrm{H}-1,84-86$ & 266.25 & CUBE741711 & -0.4 & 4.5 & 16.13 & 1.80 & 6.42 & 0.49 & $1.952 \mathrm{E}-09$ & -0.12 & \\
\hline $29 \mathrm{H}-2,84-86$ & 267.75 & CUBE741731 & 0.7 & 5.6 & 11.36 & 1.73 & 3.92 & 1.01 & $3.473 \mathrm{E}-09$ & 0.19 & \\
\hline $29 \mathrm{H}-3,84-86$ & 269.25 & CUBE741741 & -3.4 & 1.5 & 12.83 & 1.72 & 4.80 & 0.22 & $8.348 \mathrm{E}-10$ & -0.04 & \\
\hline $29 \mathrm{H}-4,84-86$ & 270.75 & CUBE741751 & 0.9 & 5.8 & 14.29 & 1.75 & 5.54 & 0.74 & $2.852 \mathrm{E}-09$ & 0.29 & \\
\hline $29 \mathrm{H}-5,84-86$ & 272.25 & CUBE741761 & -1.8 & 3.1 & 15.15 & 1.75 & 6.05 & 0.35 & $1.413 \mathrm{E}-09$ & -1.70 & \\
\hline $29 \mathrm{H}-6,84-86$ & 273.75 & CUBE741771 & 3.6 & 8.5 & 14.83 & 1.84 & 5.55 & 1.07 & $4.021 \mathrm{E}-09$ & -3.08 & \\
\hline $29 \mathrm{H}-7,59-61$ & 275.00 & CUBE741721 & -7.9 & -3.0 & 14.80 & 1.89 & 5.40 & -0.39 & $-1.438 \mathrm{E}-09$ & -2.90 & \\
\hline $30 \mathrm{H}-1,84-86$ & 275.75 & CUBE742871 & -9.2 & -4.3 & 15.80 & 1.80 & 6.23 & -0.49 & $-1.914 \mathrm{E}-09$ & 0.51 & \\
\hline $30 \mathrm{H}-2,84-86$ & 277.25 & CUBE742891 & -9.2 & -4.3 & 15.11 & 1.78 & 5.92 & -0.50 & $-1.978 \mathrm{E}-09$ & 0.32 & \\
\hline $30 \mathrm{H}-3,84-86$ & 278.75 & CUBE742901 & -7.6 & -2.7 & 15.32 & 1.76 & 6.10 & -0.31 & $-1.222 \mathrm{E}-09$ & -0.06 & \\
\hline $30 \mathrm{H}-4,84-86$ & 280.25 & CUBE742911 & -5.5 & -0.6 & 15.57 & 1.77 & 6.22 & -0.07 & $-2.819 \mathrm{E}-10$ & 0.42 & \\
\hline $30 \mathrm{H}-5,84-86$ & 281.75 & CUBE742921 & -5.6 & -0.7 & 14.70 & 1.75 & 5.79 & -0.08 & $-3.338 \mathrm{E}-10$ & 0.22 & \\
\hline $30 \mathrm{H}-6,84-86$ & 283.25 & CUBE742931 & -3.8 & 1.1 & 15.76 & 1.76 & 6.35 & 0.13 & $5.081 \mathrm{E}-10$ & 0.42 & \\
\hline $30 \mathrm{H}-7,59-61$ & 284.50 & CUBE742881 & -1.3 & 3.6 & 14.38 & 1.76 & 5.56 & 0.45 & $1.746 \mathrm{E}-09$ & 0.86 & \\
\hline $31 \mathrm{H}-1,84-86$ & 285.25 & CUBE744131 & -9.2 & -4.3 & 14.67 & 1.77 & 5.69 & -0.53 & $-2.038 \mathrm{E}-09$ & 0.86 & \\
\hline $31 \mathrm{H}-2,84-86$ & 286.75 & CUBE744141 & -7.8 & -2.9 & 15.66 & 1.78 & 6.23 & -0.33 & $-1.305 E-09$ & 0.68 & \\
\hline
\end{tabular}


Table T19 (continued). (Continued on next page.)

\begin{tabular}{|c|c|c|c|c|c|c|c|c|c|c|c|}
\hline \multirow[b]{2}{*}{$\begin{array}{l}\text { Core, section, } \\
\text { interval }(\mathrm{cm})\end{array}$} & \multirow[b]{2}{*}{$\begin{array}{l}\text { Depth } \\
\text { CSF (m) }\end{array}$} & \multirow[b]{2}{*}{ LIMS ID } & \multicolumn{2}{|c|}{ Susceptibility } & \multirow[b]{2}{*}{$\begin{array}{l}\text { Total mass } \\
\quad(\mathrm{g})\end{array}$} & \multirow{2}{*}{$\begin{array}{c}\text { Bulk } \\
\text { density } \\
\left(\mathrm{g} / \mathrm{cm}^{3}\right)\end{array}$} & \multirow[b]{2}{*}{$\begin{array}{l}\text { Volume } \\
\left(\mathrm{cm}^{3}\right)\end{array}$} & \multicolumn{3}{|c|}{ Susceptibility } & \multirow[b]{2}{*}{ Scale factor } \\
\hline & & & $\begin{array}{l}\text { Raw } \\
\left(10^{-6}\right)\end{array}$ & $\begin{array}{c}\text { Corrected } \\
\left(10^{-6}\right)\end{array}$ & & & & $\begin{array}{c}\text { Volume normalized } \\
\qquad\left(10^{-5}\right)\end{array}$ & $\begin{array}{l}\text { Mass normalized } \\
\left(\mathrm{m}^{3} / \mathrm{kg}\right)\end{array}$ & $\begin{array}{l}\text { Whole core } \\
\text { (raw values) }\end{array}$ & \\
\hline $31 \mathrm{H}-3,84-86$ & 288.25 & CUBE744151 & -7.3 & -2.4 & 14.73 & 1.78 & 5.71 & -0.29 & $-1.123 \mathrm{E}-09$ & 0.44 & \\
\hline $31 \mathrm{H}-4,84-86$ & 289.75 & CUBE744161 & -7.6 & -2.7 & 14.60 & 1.81 & 5.54 & -0.35 & $-1.318 \mathrm{E}-09$ & 0.33 & \\
\hline $31 \mathrm{H}-5,94-96$ & 291.35 & CUBE744171 & -5.3 & -0.4 & 14.66 & 1.80 & 5.59 & -0.06 & $-2.125 \mathrm{E}-10$ & 0.41 & \\
\hline $31 \mathrm{H}-6,84-86$ & 292.75 & CUBE744181 & -8.0 & -3.1 & 15.37 & 1.80 & 5.98 & -0.36 & $-1.389 \mathrm{E}-09$ & 0.30 & \\
\hline $31 \mathrm{H}-7,69-71$ & 294.10 & CUBE744191 & -8.3 & -3.4 & 14.40 & 1.81 & 5.42 & -0.44 & $-1.649 \mathrm{E}-09$ & 0.59 & \\
\hline $32 \mathrm{H}-1,84-86$ & 294.75 & CUBE744711 & -5.0 & -0.1 & 14.63 & 1.80 & 5.58 & -0.01 & $-4.163 \mathrm{E}-11$ & 1.24 & \\
\hline $32 \mathrm{H}-2,84-86$ & 296.25 & CUBE744721 & -8.9 & -4.0 & 15.37 & 1.80 & 5.99 & -0.46 & $-1.800 \mathrm{E}-09$ & 0.87 & \\
\hline $32 \mathrm{H}-3,84-86$ & 297.75 & CUBE744731 & -8.3 & -3.4 & 15.42 & 1.80 & 6.02 & -0.39 & $-1.541 \mathrm{E}-09$ & 0.48 & \\
\hline $32 \mathrm{H}-4,84-86$ & 299.25 & CUBE744741 & -9.9 & -5.0 & 13.81 & 1.78 & 5.19 & -0.67 & $-2.522 \mathrm{E}-09$ & 0.43 & \\
\hline $32 \mathrm{H}-5,109-111$ & 301.00 & CUBE744751 & -9.0 & -4.1 & 15.28 & 1.74 & 6.14 & -0.46 & $-1.866 \mathrm{E}-09$ & 0.74 & \\
\hline $32 \mathrm{H}-6,84-86$ & 302.25 & CUBE744761 & -7.8 & -2.9 & 14.97 & 1.81 & 5.73 & -0.35 & $-1.341 \mathrm{E}-09$ & 1.44 & \\
\hline $32 \mathrm{H}-7,49-51$ & 303.40 & CUBE744771 & -6.8 & -1.9 & 15.23 & 1.81 & 5.88 & -0.23 & $-8.871 \mathrm{E}-10$ & 0.20 & \\
\hline $33 \mathrm{H}-1,94-96$ & 304.35 & CUBE745891 & -8.3 & -3.4 & 14.80 & 1.82 & 5.62 & -0.42 & $-1.608 \mathrm{E}-09$ & -1.30 & \\
\hline $33 \mathrm{H}-2,84-86$ & 305.75 & CUBE745901 & -4.8 & 0.1 & 14.67 & 1.72 & 5.85 & 0.01 & 4.867E-11 & -1.19 & \\
\hline $33 \mathrm{H}-3,84-86$ & 307.25 & CUBE745911 & -7.4 & -2.5 & 14.54 & 1.77 & 5.61 & -0.32 & $-1.219 \mathrm{E}-09$ & -0.87 & \\
\hline $33 \mathrm{H}-4,84-86$ & 308.75 & CUBE745921 & -8.2 & -3.3 & 14.89 & 1.80 & 5.71 & -0.40 & $-1.532 \mathrm{E}-09$ & -1.30 & \\
\hline $33 \mathrm{H}-5,84-86$ & 310.25 & CUBE745931 & -6.6 & -1.7 & 14.88 & 1.74 & 5.93 & -0.20 & $-7.969 \mathrm{E}-10$ & -1.03 & \\
\hline $33 \mathrm{H}-6,84-86$ & 311.75 & CUBE745941 & -7.5 & -2.6 & 15.68 & 1.71 & 6.50 & -0.28 & $-1.179 \mathrm{E}-09$ & -0.98 & \\
\hline $33 \mathrm{H}-7,69-71$ & 313.10 & CUBE745951 & -9.1 & -4.2 & 15.40 & 1.76 & 6.14 & -0.48 & $-1.919 \mathrm{E}-09$ & -0.85 & \\
\hline $34 \mathrm{H}-1,84-86$ & 313.75 & CUBE746381 & -8.5 & -3.6 & 14.24 & 1.81 & 5.32 & -0.47 & $-1.765 \mathrm{E}-09$ & -0.11 & \\
\hline $34 \mathrm{H}-3,84-86$ & 315.35 & CUBE746391 & -7.8 & -2.9 & 14.31 & 1.81 & 5.38 & -0.38 & $-1.411 \mathrm{E}-09$ & -0.23 & \\
\hline $34 \mathrm{H}-4,84-86$ & 316.85 & CUBE746401 & -7.7 & -2.8 & 14.29 & 1.66 & 5.84 & -0.33 & $-1.365 E-09$ & 0.50 & \\
\hline $34 \mathrm{H}-5,84-86$ & 318.35 & CUBE746411 & -7.3 & -2.4 & 15.09 & 1.86 & 5.66 & -0.30 & $-1.111 \mathrm{E}-09$ & 0.13 & \\
\hline $34 \mathrm{H}-6,84-86$ & 319.85 & CUBE746421 & -8.9 & -4.0 & 14.64 & 1.84 & 5.47 & -0.52 & $-1.932 \mathrm{E}-09$ & -0.02 & \\
\hline $34 \mathrm{H}-7,70-72$ & 321.21 & CUBE746431 & -3.2 & 1.8 & 13.96 & 1.79 & 5.23 & 0.23 & $8.775 \mathrm{E}-10$ & 0.51 & \\
\hline $35 \mathrm{H}-1,84-86$ & 323.25 & CUBE747471 & -8.8 & -3.9 & 15.10 & 1.79 & 5.87 & -0.47 & $-1.813 \mathrm{E}-09$ & 0.40 & \\
\hline $35 \mathrm{H}-2,84-86$ & 324.75 & CUBE747481 & -8.5 & -3.6 & 14.67 & 1.82 & 5.54 & -0.46 & $-1.727 \mathrm{E}-09$ & 0.42 & \\
\hline $35 \mathrm{H}-3,84-86$ & 326.25 & CUBE747501 & -8.6 & -3.7 & 14.69 & 1.81 & 5.57 & -0.46 & $-1.754 \mathrm{E}-09$ & 0.41 & \\
\hline $35 \mathrm{H}-4,84-86$ & 327.75 & CUBE747521 & -8.7 & -3.8 & 14.81 & 1.83 & 5.59 & -0.48 & $-1.806 \mathrm{E}-09$ & 0.45 & \\
\hline $35 \mathrm{H}-5,84-86$ & 329.25 & CUBE747531 & -7.8 & -2.9 & 15.12 & 1.84 & 5.72 & -0.35 & $-1.325 \mathrm{E}-09$ & 0.26 & \\
\hline $35 \mathrm{H}-6,84-86$ & 330.75 & CUBE747541 & -9.4 & -4.5 & 15.65 & 1.69 & 6.54 & -0.48 & $-2.007 \mathrm{E}-09$ & 0.27 & \\
\hline $35 \mathrm{H}-7,84-86$ & 332.25 & CUBE747551 & -8.4 & -3.5 & 15.15 & 1.83 & 5.78 & -0.43 & $-1.621 \mathrm{E}-09$ & 0.07 & \\
\hline $36 \mathrm{H}-1,84-86$ & 332.75 & CUBE747901 & -10.6 & -5.7 & 14.80 & 1.78 & 5.73 & -0.69 & $-2.677 \mathrm{E}-09$ & 0.51 & \\
\hline $36 \mathrm{H}-2,84-86$ & 334.25 & CUBE747911 & -8.4 & -3.5 & 14.29 & 1.77 & 5.47 & -0.45 & $-1.738 \mathrm{E}-09$ & 1.35 & \\
\hline $36 \mathrm{H}-3,84-86$ & 335.75 & CUBE747921 & -5.4 & -0.5 & 14.69 & 1.81 & 5.59 & -0.06 & $-2.297 \mathrm{E}-10$ & 0.81 & \\
\hline $36 \mathrm{H}-4,84-86$ & 337.25 & CUBE747931 & -7.4 & -2.5 & 14.29 & 1.82 & 5.34 & -0.33 & $-1.215 \mathrm{E}-09$ & 0.03 & \\
\hline $36 \mathrm{H}-5,84-86$ & 338.75 & CUBE747941 & -11.0 & -6.1 & 14.54 & 1.80 & 5.53 & -0.77 & $-2.946 \mathrm{E}-09$ & -0.16 & \\
\hline $36 \mathrm{H}-6,84-86$ & 340.25 & CUBE747951 & -2.6 & 2.3 & 15.44 & 1.78 & 6.08 & 0.26 & $1.028 \mathrm{E}-09$ & 0.94 & \\
\hline $36 \mathrm{H}-7,54-56$ & 341.45 & CUBE747961 & -5.7 & -0.8 & 14.80 & 1.78 & 5.73 & -0.10 & $-3.930 \mathrm{E}-10$ & -0.28 & \\
\hline $38 X-3,86-88$ & 354.97 & CUBE749861 & -6.2 & -1.3 & 12.87 & 1.75 & 4.73 & -0.20 & $-7.326 \mathrm{E}-10$ & -0.05 & \\
\hline $38 X-5,113-115$ & 358.24 & CUBE749871 & -9.1 & -4.2 & 13.71 & 1.71 & 5.32 & -0.55 & $-2.132 \mathrm{E}-09$ & 0.48 & \\
\hline $39 \times-3,94-96$ & 364.65 & CUBE750471 & -6.9 & -2.0 & 13.75 & 1.84 & 4.99 & -0.28 & $-1.014 \mathrm{E}-09$ & 0.77 & \\
\hline $39 X-5,80-82$ & 367.51 & CUBE750481 & -8.0 & -3.1 & 12.72 & 1.84 & 4.42 & -0.50 & $-1.727 \mathrm{E}-09$ & 1.18 & \\
\hline $40 \mathrm{X}-2,84-86$ & 372.55 & CUBE751501 & -5.8 & -0.9 & 12.38 & 1.75 & 4.44 & -0.14 & $-5.174 \mathrm{E}-10$ & 1.18 & \\
\hline 40X-3, 89-91 & 374.10 & CUBE751511 & -8.2 & -3.3 & 12.46 & 1.77 & 4.43 & -0.52 & $-1.837 \mathrm{E}-09$ & 1.74 & \\
\hline $40 X-4,76-78$ & 375.47 & CUBE751521 & -1.3 & 3.6 & 14.50 & 1.74 & 5.68 & 0.45 & 1.746E-09 & 5.10 & $8.75 \mathrm{E}-02$ \\
\hline $41 X-2,69-71$ & 381.90 & CUBE751981 & -3.4 & 1.5 & 14.62 & 1.88 & 5.34 & 0.19 & 7.019E-10 & 7.42 & $2.59 \mathrm{E}-02$ \\
\hline $41 X-3,89-91$ & 383.60 & CUBE751991 & -5.9 & -1.0 & 15.63 & 1.91 & 5.78 & -0.13 & $-4.622 \mathrm{E}-10$ & 1.16 & \\
\hline $41 X-5,36-38$ & 386.07 & CUBE752001 & 0.2 & 5.1 & 13.88 & 1.93 & 4.82 & 0.74 & 2.557E-09 & 0.44 & \\
\hline $42 \mathrm{X}-2,119-121$ & 391.90 & CUBE752811 & 3.1 & 8.0 & 14.15 & 1.84 & 5.20 & 1.07 & $3.945 \mathrm{E}-09$ & -0.34 & \\
\hline
\end{tabular}


Table T19 (continued).

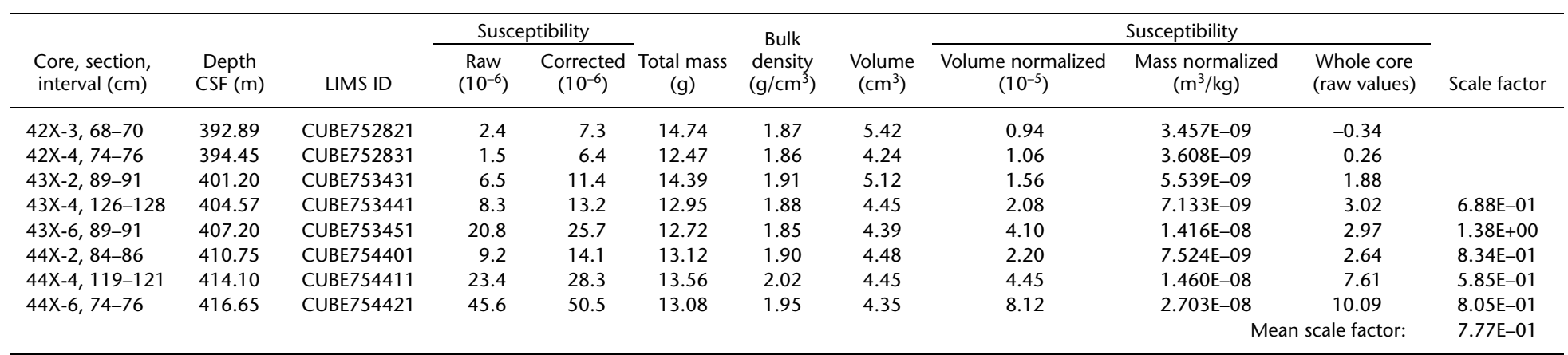

Notes: Depth = depth to middle of discrete sample measured in meters using the core depth below seafloor, method A (CSF), depth scale. LIMS ID = sample identification within the Laboratory Information Management System (LIMS) database. Susceptibility raw = volume magnetic susceptibility (in SI units) of the discrete sample measured in the Kappabridge with the volume of the cube assumed to be $7 \mathrm{~cm}^{3}$. Susceptibility corrected $=$ the susceptibility of the plastic cube with a label was determined to be $-4.9 \mathrm{E}-06$ (SI) with a standard error of $\pm 0.19 \mathrm{E}-06$. Mass = mass of sample including mass of plastic cube, which has a mean of $4.5921 \mathrm{~g}$. Bulk density = density from moisture and density (MAD) measurements. When these were not available or were obviously anomalous, we used a density of $1.2 \mathrm{~m}^{3} / \mathrm{kg}$. Volume = volume of sediments, calculated by subtracting mass of plastic cube from total mass and then dividing by bulk density. Volume normalized susceptibility = susceptibility of discrete samples normalized by true sample volume. These are unitless in the SI unit system. Mass normalized susceptibility = susceptibility of discrete samples normalize by mass of sediments in each sample cube. Scale factor = factor whole-core raw susceptibility values would need to be multiplied by to convert them to SI volume normalized susceptibilities. 


\begin{tabular}{|c|c|c|c|c|c|c|c|c|c|}
\hline \multirow[b]{2}{*}{ Polarity chron } & \multirow[b]{2}{*}{$\begin{array}{l}\text { Age } \\
(\mathrm{Ma})\end{array}$} & \multicolumn{4}{|c|}{ Hole U1335A } & \multicolumn{4}{|c|}{ Hole U1335B } \\
\hline & & $\begin{array}{l}\text { Range } \\
\text { CSF (m) }\end{array}$ & $\begin{array}{l}\text { Best estimate } \\
\text { CSF }(m)\end{array}$ & $\begin{array}{c}\text { Best estimate core, } \\
\text { section, interval }(\mathrm{cm})\end{array}$ & $\begin{array}{l}\text { Measurement } \\
\text { type }\end{array}$ & $\begin{array}{c}\text { Range } \\
\text { CSF (m) }\end{array}$ & $\begin{array}{l}\text { Best estimate } \\
\text { CSF }(\mathrm{m})\end{array}$ & $\begin{array}{c}\text { Best estimate core, } \\
\text { section, interval }(\mathrm{cm})\end{array}$ & $\begin{array}{l}\text { Measurement } \\
\text { type }\end{array}$ \\
\hline $\mathrm{C} 1 \mathrm{n}$ & 0.000 & $0.000-0.000$ & 0.000 & Mudline & & & & Not recovered & \\
\hline $\mathrm{C} 1 \mathrm{n}-\mathrm{C} 1 \mathrm{r} .1 \mathrm{r}$ & 0.781 & $5.125-5.225$ & 5.175 & $1 \mathrm{H}-4,67.50$ & Split core & $5.775-5.850$ & 5.813 & $2 \mathrm{H}-2,101.25$ & Split core \\
\hline $\mathrm{C} 1 \mathrm{r} .1 \mathrm{r}-\mathrm{C} 1 \mathrm{r} .1 \mathrm{n}$ & 0.988 & $6.375-6.450$ & 6.413 & $1 \mathrm{H}-5,41.25$ & Split core & $6.875-6.925$ & 6.900 & $2 \mathrm{H}-3,60.00$ & Split core \\
\hline $\mathrm{C} 1 \mathrm{r} .1 \mathrm{n}-\mathrm{C} 1 \mathrm{r} .2 \mathrm{r}$ & 1.072 & $6.825-6.875$ & 6.850 & $1 \mathrm{H}-5,85.00$ & Split core & $7.275-7.375$ & 7.325 & $2 \mathrm{H}-3,102.50$ & Split core \\
\hline $\mathrm{C} 1 \mathrm{r} .2 \mathrm{r}-\mathrm{C} 1 \mathrm{r} .2 \mathrm{n}$ & 1.173 & $7.450-7.525$ & 7.488 & $1 \mathrm{H}-6,28.75$ & Split core & & & Not identified & \\
\hline $\mathrm{C} 1 \mathrm{r} .2 \mathrm{n}-\mathrm{C} 1 \mathrm{r} .2 \mathrm{r}$ & 1.185 & $7.575-7.650$ & 7.613 & $1 \mathrm{H}-6,41.25$ & Split core & & & Not identified & \\
\hline $\mathrm{C} 1 \mathrm{r} \cdot 2 \mathrm{r}-\mathrm{C} 2 \mathrm{n}$ & 1.778 & $9.525-9.550$ & 9.538 & $2 \mathrm{H}-1,63.75$ & Split core & $10.700-10.875$ & 10.788 & Between Sections $2 \mathrm{H}-5$ and 6 & Split core \\
\hline$C 2 n-C 2 r .1 r$ & 1.945 & $10.200-10.225$ & 10.213 & $2 \mathrm{H}-1,132.50$ & Split core & $11.275-11.375$ & 11.325 & $2 \mathrm{H}-6,52.50$ & Split core \\
\hline $\mathrm{C} 2 \mathrm{r} .1 \mathrm{r}-\mathrm{C} 2 \mathrm{r} .1 \mathrm{n}$ & 2.128 & $10.950-10.975$ & 10.963 & $2 \mathrm{H}-2,56.75$ & Split core & $11.650-11.725$ & 11.688 & $2 \mathrm{H}-6,88.75$ & Split core \\
\hline $\mathrm{C} 2 \mathrm{r} .1 \mathrm{n}-\mathrm{C} 2 \mathrm{r} .2 \mathrm{r}$ & 2.148 & $10.975-11.000$ & 10.988 & $2 \mathrm{H}-2,58.75$ & Split core & $11.725-11.775$ & 11.750 & $2 \mathrm{H}-6,95.00$ & Split core \\
\hline C2r.2r-C2An.1n & 2.581 & $13.550-13.600$ & 13.575 & $2 \mathrm{H}-4,17.50$ & Split core & $13.475-13.575$ & 13.525 & $3 \mathrm{H}-1,73.75$ & Split core \\
\hline C2An.1n-C2An.1r & 3.032 & $16.025-16.075$ & 16.050 & $2 \mathrm{H}-5,115.00$ & Split core & $15.725-15.900$ & 15.813 & Between Sections $3 \mathrm{H}-2$ and 3 & Split core \\
\hline C2An.1r-C2An.2n & 3.116 & $16.275-16.300$ & 16.288 & $2 \mathrm{H}-5,138.75$ & Split core & $16.075-16.150$ & 16.113 & $3 \mathrm{H}-3,31.25$ & Split core \\
\hline C2An.2n-C2An.2r & 3.207 & $16.725-16.750$ & 16.738 & $2 \mathrm{H}-6,33.75$ & Split core & $16.525-16.625$ & 16.575 & $3 \mathrm{H}-3,77.50$ & Split core \\
\hline C2An.2r-C2An.3n & 3.330 & $17.175-17.225$ & 17.200 & $2 \mathrm{H}-6,80.00$ & Split core & $17.025-17.050$ & 17.038 & $3 \mathrm{H}-3,123.75$ & Split core \\
\hline C2An.3n-C2Ar & 3.596 & $18.325-18.375$ & 18.350 & $2 \mathrm{H}-7,45.00$ & Split core & $18.175-18.225$ & 18.200 & $3 \mathrm{H}-4,90.00$ & Split core \\
\hline $\mathrm{C} 2 \mathrm{Ar}-\mathrm{C} 3 \mathrm{n} .1 \mathrm{n}$ & 4.187 & $20.350-20.475$ & 20.413 & $3 \mathrm{H}-2,51.25$ & Split core & $20.500-20.550$ & 20.525 & $3 \mathrm{H}-6,22.50$ & Split core \\
\hline C $3 n .1 n-C 3 n .1 r$ & 4.300 & $21.125-21.275$ & 21.200 & $3 \mathrm{H}-2,130.00$ & Split core & $21.275-21.300$ & 21.288 & $3 \mathrm{H}-6,98.75$ & Split core \\
\hline$C 3 n .1 r-C 3 n .2 n$ & 4.493 & $22.475-22.675$ & 22.575 & $3 \mathrm{H}-3,117.50$ & Split core & $22.275-23.125$ & & Between Sections $3 \mathrm{H}-7$ and $4 \mathrm{H}-1$ & Split core \\
\hline C $3 n .2 n-C 3 n .2 r$ & 4.631 & $23.575-23.625$ & 23.600 & $3 \mathrm{H}-4,70.00$ & Split core & $22.275-23.125$ & & Between Sections $3 \mathrm{H}-7$ and $4 \mathrm{H}-1$ & Split core \\
\hline$C 3 n .2 r-C 3 n .3 n$ & 4.799 & $24.975-25.075$ & 25.025 & $3 \mathrm{H}-5,62.50$ & Split core & $24.025-24.075$ & 24.050 & $4 \mathrm{H}-2,25.00$ & Split core \\
\hline C $3 n \cdot 3 n-C 3 n \cdot 3 r$ & 4.896 & $25.650-25.700$ & 25.675 & $3 \mathrm{H}-5,127.50$ & Split core & $24.675-24.725$ & 24.700 & $4 \mathrm{H}-2,90.00$ & Split core \\
\hline C $3 n .3 r-C 3 n .4 n$ & 4.997 & $26.200-26.300$ & 26.250 & $3 \mathrm{H}-6,35.00$ & Split core & $25.125-25.175$ & 25.150 & $4 \mathrm{H}-2,135.00$ & Split core \\
\hline$C 3 n \cdot 4 n-C 3 r$ & 5.235 & $27.925-29.125$ & 28.525 & Between Sections $3 \mathrm{H}-7$ and $4 \mathrm{H}-1$ & Split core & $26.900-26.925$ & 26.913 & $4 \mathrm{H}-4,11.25$ & Split core \\
\hline Excursion C $3 r-1 ?$ & & & & Not identified & & $27.325-27.375$ & 27.350 & $4 \mathrm{H}-4,55.00$ & Split core \\
\hline Excursion $\mathrm{C} 3 \mathrm{r}-2$ ? & & & & Not identified & & $28.550-28.575$ & 28.563 & $4 \mathrm{H}-5,26.25$ & Split core \\
\hline Excursion $\mathrm{C} 3 \mathrm{r}-3$ ? & & & & Not identified & & $28.900-28.950$ & 28.925 & $4 \mathrm{H}-5,62.50$ & Split core \\
\hline Excursion $\mathrm{C} 3 \mathrm{r}-4$ ? & & & & Not identified & & $29.925-29.975$ & 29.950 & $4 \mathrm{H}-6,15.00$ & Split core \\
\hline Excursion $\mathrm{C} 3 \mathrm{r}-5$ ? & & & & Not identified & & $30.825-30.875$ & 30.850 & $4 \mathrm{H}-6,105.00$ & Split core \\
\hline C3r-C3An.1n & 6.033 & $30.775-31.400$ & 31.088 & $4 \mathrm{H}-3,25.00$ & Split core & $31.225-31.375$ & 31.300 & Between Sections $4 \mathrm{H}-4$ and 5 & Split core \\
\hline C3An.1n-C3An.1r & 6.252 & $33.225-33.450$ & 33.338 & $4 \mathrm{H}-4,93.75$ & Split core & $32.150-32.225$ & 32.188 & $5 \mathrm{H}-1,38.75$ & Split core \\
\hline C3An.1r-C3An.2n & 6.436 & $34.675-34.775$ & 34.725 & $4 \mathrm{H}-5,82.50$ & Split core & $33.525-33.575$ & 33.550 & $5 \mathrm{H}-2,25.00$ & Split core \\
\hline C3An.2n-C3Ar & 6.733 & $36.975-37.025$ & 37.000 & $4 \mathrm{H}-7,10.00$ & Split core & $35.875-35.950$ & 35.913 & $5 \mathrm{H}-3,112.50$ & Split core \\
\hline $\mathrm{C} 3 \mathrm{Ar}-\mathrm{C} 3 \mathrm{Bn}$ & 7.140 & $38.400-38.450$ & 38.425 & $5 \mathrm{H}-1,102.50$ & Split core & $38.850-38.875$ & 38.863 & $5 \mathrm{H}-5,106.25$ & Split core \\
\hline C3Bn-C3Br.1r & 7.212 & $38.575-38.625$ & 38.600 & $5 \mathrm{H}-1,120.00$ & Split core & $39.025-39.075$ & 39.050 & $5 \mathrm{H}-5,125.00$ & Split core \\
\hline C3Br.1r-C3Br.1n & 7.251 & $38.825-39.000$ & 38.913 & Between Sections $5 \mathrm{H}-1$ and 2 & Split core & $39.225-39.375$ & 39.300 & Between Sections $5 \mathrm{H}-5$ and 6 & Split core \\
\hline C $3 B r .1 n-C 3 B r .2 r$ & 7.285 & $39.700-39.750$ & 39.725 & $5 \mathrm{H}-2,82.5$ & Split core & $39.550-39.600$ & 39.575 & $5 \mathrm{H}-6,27.50$ & Split core \\
\hline $\mathrm{C} 3 \mathrm{Br} .2 \mathrm{r}-\mathrm{C} 3 \mathrm{Br} .2 \mathrm{n}$ & 7.454 & $41.000-41.050$ & 41.025 & $5 \mathrm{H}-3,62.5$ & Split core & $40.375-40.450$ & 40.413 & $5 \mathrm{H}-6,111.25$ & Split core \\
\hline C $3 B r .2 n-C 3 B r .3 r$ & 7.489 & $41.150-41.200$ & 41.175 & $5 \mathrm{H}-3,77.5$ & Split core & $40.475-40.500$ & 40.488 & $5 \mathrm{H}-6,118.75$ & Split core \\
\hline C $3 B r .3 r-C 4 n .1 n$ & 7.528 & $41.250-41.300$ & 41.275 & $5 \mathrm{H}-3,87.5$ & Split core & $40.525-40.600$ & 40.563 & $5 \mathrm{H}-6,126.25$ & Split core \\
\hline$C 4 n .1 n-C 4 n .1 r$ & 7.642 & $41.350-41.450$ & 41.400 & $5 \mathrm{H}-3,100.0$ & Split core & & & Not identified & \\
\hline C $4 n .1 r-C 4 n .2 n$ & 7.695 & $41.800-42.000$ & 41.900 & Between Sections $5 \mathrm{H}-3$ and 4 & Split core & & & Not identified & \\
\hline Excursion C $4 \mathrm{n} .2 \mathrm{n}-1$ ? & & $42.350-42.450$ & 42.400 & $5 \mathrm{H}-4,102.5$ & Split core & $41.825-41.950$ & 41.888 & $6 \mathrm{H}-1,58.75$ & Split core \\
\hline$C 4 n .2 n-C 4 r .1 r$ & 8.108 & $42.850-43.000$ & 42.925 & $5 \mathrm{H}-4,50.00$ & Split core & $42.525-42.550$ & 42.538 & $6 \mathrm{H}-1,123.75$ & Split core \\
\hline Excursion C4r.1r-1? & & $43.250-43.300$ & 43.275 & $5 \mathrm{H}-4,137.5$ & Split core & $42.875-43.050$ & 42.963 & $6 \mathrm{H}-2,16.25$ & Split core \\
\hline Excursion C4r.1r-2? & & & & Not identified & & $43.250-43.450$ & 43.350 & $6 \mathrm{H}-2,55.00$ & Split core \\
\hline C4r.1r-C4r.1n & 8.254 & $44.500-44.550$ & 44.525 & $5 \mathrm{H}-5,112.5$ & Split core & $44.375-44.400$ & 44.388 & Between Sections $6 \mathrm{H}-2$ and 3 & Split core \\
\hline C4r.1n-C4r.2r & 8.300 & $44.800-45.000$ & 44.900 & Between $5 \mathrm{H}-5$ and 6 & Split core & $44.650-44.750$ & 44.700 & $6 \mathrm{H}-3,40.00$ & Split core \\
\hline C4r.2r-C4An & 8.769 & $48.300-48.500$ & 48.400 & Between $6 \mathrm{H}-1$ and 2 & Split core & $48.875-48.950$ & 48.913 & $6 \mathrm{H}-6,11.25$ & Split core \\
\hline Excursion C4An-1 ? & & $48.700-48.750$ & 48.725 & $6 \mathrm{H}-2,32.5$ & Split core & $49.075-49.125$ & 49.100 & $6 \mathrm{H}-6,30.00$ & Split core \\
\hline
\end{tabular}




\begin{tabular}{|c|c|c|c|c|c|c|c|c|c|}
\hline \multirow[b]{2}{*}{ Polarity chron } & \multirow[b]{2}{*}{$\begin{array}{l}\text { Age } \\
(\mathrm{Ma})\end{array}$} & \multicolumn{4}{|c|}{ Hole U1335A } & \multicolumn{4}{|c|}{ Hole U1335B } \\
\hline & & $\begin{array}{l}\text { Range } \\
\text { CSF }(\mathrm{m})\end{array}$ & $\begin{array}{l}\text { Best estimate } \\
\text { CSF }(\mathrm{m})\end{array}$ & $\begin{array}{l}\text { Best estimate core, } \\
\text { section, interval }(\mathrm{cm})\end{array}$ & $\begin{array}{l}\text { Measurement } \\
\text { type }\end{array}$ & $\begin{array}{l}\text { Range } \\
\text { CSF }(\mathrm{m})\end{array}$ & $\begin{array}{l}\text { Best estimate } \\
\text { CSF }(\mathrm{m})\end{array}$ & $\begin{array}{c}\text { Best estimate core, } \\
\text { section, interval }(\mathrm{cm})\end{array}$ & $\begin{array}{l}\text { Measurement } \\
\text { type }\end{array}$ \\
\hline Excursion C4An-2 ? & & & & Not identified & & $49.700-49.800$ & 49.750 & $6 \mathrm{H}-6,95.00$ & Split core \\
\hline C4An-C4Ar.1r & 9.098 & $56.850-56.900$ & 56.875 & $7 \mathrm{H}-1,96.25$ & Split core & $57.225-57.275$ & 57.250 & $7 \mathrm{H}-5,45.00$ & Split core \\
\hline Excursion C4Ar.1r-1 ? & & & & Not identified & & $57.425-57.500$ & 57.463 & $7 \mathrm{H}-5,66.25$ & Split core \\
\hline Excursion C4Ar.1r-2? & & $57.350-57.375$ & 57.363 & $7 \mathrm{H}-1,47.50$ & Split core & $57.550-57.675$ & 57.613 & $7 \mathrm{H}-5,81.25$ & Split core \\
\hline C4Ar.1r-C4Ar.1n & 9.312 & $57.700-57.775$ & 57.738 & $7 \mathrm{H}-1,133.75$ & Split core & $57.925-58.075$ & 58.000 & $7 \mathrm{H}-5,120.00$ & Split core \\
\hline C4Ar.1n-C4Ar.2r & 9.409 & $58.300-58.350$ & 58.325 & $7 \mathrm{H}-2,42.50$ & Split core & $58.725-58.800$ & 58.763 & $7 \mathrm{H}-6,42.50$ & Split core \\
\hline C4Ar.2r-C4Ar.2n & 9.656 & $59.300-59.325$ & 59.313 & $7 \mathrm{H}-2,141.25$ & Split core & $59.725-59.875$ & 59.800 & Between Sections $7 \mathrm{H}-6$ and 7 & Split core \\
\hline C4Ar.2n-C4Ar.3r & 9.717 & $59.650-59.700$ & 59.675 & $7 \mathrm{H}-3,27.50$ & Split core & $60.075-60.125$ & 60.100 & $7 \mathrm{H}-7,30.00$ & Split core \\
\hline C4Ar.3r-C5n.1n & 9.779 & $59.875-59.975$ & 59.925 & $7 \mathrm{H}-3,52.50$ & Split core & $60.325-60.400$ & 60.363 & $7 \mathrm{H}-7,56.25$ & Split core \\
\hline C5n.1n-C5n.1r & 9.934 & $60.775-61.000$ & 60.888 & Between Sections $7 \mathrm{H}-3$ and 4 & Split core & $60.600-60.625$ & & Between Sections $7 \mathrm{H}-7$ and $8 \mathrm{H}-1$ & Split core \\
\hline$C 5 n .1 r-C 5 n .2 n$ & 9.987 & $61.000-61.050$ & 61.025 & $7 \mathrm{H}-4,12.50$ & Split core & $60.600-60.625$ & & Between Sections $7 \mathrm{H}-7$ and $8 \mathrm{H}-1$ & Split core \\
\hline C5n.2n-C5r.1r & 11.040 & Below 65.95 & & Below 7H-7, 55.00 & Split core & $65.350-65.375$ & 65.363 & $8 \mathrm{H}-4,56.25$ & Split core \\
\hline C5r.1r-C5r.1n & 11.118 & & & Not identified & & $66.025-66.075$ & 66.050 & $8 \mathrm{H}-4,125.00$ & Split core \\
\hline C5r.1n-C5r.2r & 11.154 & & & Not identified & & Below 66.225 & & Below $8 \mathrm{H}-4142.5$ & Split core \\
\hline C5r.2r-C5r.2n & 11.554 & & & Not identified & & & & Not identified & \\
\hline C5r.2n-C5r.3r & 11.614 & & & Not identified & & & & Not identified & \\
\hline C5r.3r-C5An.1n & 12.014 & & & Not identified & & & & Not identified & \\
\hline C5An.1n-C5An.1r & 12.116 & & & Not identified & & & & Not identified & \\
\hline C5An. $1 \mathrm{r}-\mathrm{C} 5 \mathrm{An} .2 \mathrm{n}$ & 12.207 & & & Not identified & & & & Not identified & \\
\hline C5An.2n-C5Ar.1r & 12.415 & & & Not identified & & & & Not identified & \\
\hline C5Ar.1r-C5Ar.1n & 12.730 & & & Not identified & & & & Not identified & \\
\hline C5Ar.1n-C5Ar.2r & 12.765 & & & Not identified & & & & Not identified & \\
\hline C5Ar.2r-C5Ar.2n & 12.820 & & & Not identified & & & & Not identified & \\
\hline C5Ar.2n-C5Ar.3r & 12.878 & & & Not identified & & & & Not identified & \\
\hline C5Ar.3r-C5AAn & 13.015 & & & Not identified & & Above 107.95 & & Above $13 \mathrm{H}-1,15.00$ & Split core \\
\hline C5AAn-C5AAr & 13.183 & & & Not identified & & $110.675-110.900$ & 110.788 & Between Sections $13 \mathrm{H}-2$ and 3 & Split core \\
\hline $\mathrm{C} 5 \mathrm{AAr}-\mathrm{C} 5 \mathrm{ABn}$ & 13.369 & & & Not identified & & $113.275-113.350$ & 113.313 & $13 \mathrm{H}-2,101.25$ & Split core \\
\hline $\mathrm{C} 5 \mathrm{ABn}-\mathrm{C} 5 \mathrm{ABr}$ & 13.605 & & & Not identified & & $117.800-117.875$ & 117.838 & $14 \mathrm{H}-1,53.75$ & Split core \\
\hline $\mathrm{C} 5 \mathrm{ABr}-\mathrm{C} 5 \mathrm{ACn}$ & 13.734 & & & Not identified & & $118.975-120.375$ & 119.675 & $14 \mathrm{H}-2,87.50$ & Split core \\
\hline Excursion C5ACn-1? & & & & Not identified & & $123.075-123.100$ & 123.088 & $14 \mathrm{H}-4,128.75$ & Split core \\
\hline $\mathrm{C} 5 \mathrm{ACn}-\mathrm{C} 5 \mathrm{ACr}$ & 14.095 & & & Not identified & & $123.925-124.000$ & 123.963 & $14 \mathrm{H}-5,66.25$ & Split core \\
\hline $\mathrm{C} 5 \mathrm{ACr}-\mathrm{C} 5 \mathrm{ADn}$ & 14.194 & & & Not identified & & $124.700-125.025$ & 124.863 & Between Sections $14 \mathrm{H}-5$ and 6 & Split core \\
\hline Excursion C5ADn-1? & & & & Not identified & & $125.875-125.975$ & 125.925 & $14 \mathrm{H}-6,112.50$ & Split core \\
\hline Excursion C5ADn-2? & & & & Not identified & & $130.600-130.650$ & 130.625 & $15 \mathrm{H}-3,82.50$ & Split core \\
\hline Excursion C5ADn-3? & & & & Not identified & & $135.100-135.150$ & 135.125 & $15 \mathrm{H}-6,82.50$ & Split core \\
\hline C5ADn-C5ADr & 14.581 & & & Not identified & & $137.350-137.425$ & 137.388 & $16 \mathrm{H}-1,108.75$ & Split core \\
\hline Excursion C5ADr-1 ? & & & & Not identified & & $138.175-138.450$ & 138.313 & $16 \mathrm{H}-2,51.25$ & Split core \\
\hline Excursion C5ADr-2? & & & & Not identified & & $139.775-140.000$ & 139.888 & $16 \mathrm{H}-3,58.75$ & Split core \\
\hline Excursion C5ADr-3? & & & & Not identified & & $140.125-140.200$ & 140.163 & $16 \mathrm{H}-3,86.25$ & Split core \\
\hline Excursion C5ADr-4? & & & & Not identified & & $141.650-142.025$ & 141.838 & $16 \mathrm{H}-4,103.75$ & Split core \\
\hline C5ADr-C5Bn.1n & 14.784 & & & Not identified & & $143.050-143.150$ & 143.100 & $16 \mathrm{H}-5,80.00$ & Split core \\
\hline C5Bn.1n-C5Bn.1r & 14.877 & & & Not identified & & $145.85-146.65$ & & Between Sections $16 \mathrm{H}-7$ and $17 \mathrm{H}-1$ & \\
\hline C5Bn.1r-C5Bn.2n & 15.032 & & & Not identified & & $149.175-149.375$ & 149.275 & $17 \mathrm{H}-3,47.50$ & Split core \\
\hline Excursion C $5 B n \cdot 2 n-1$ ? & & & & Not identified & & $150.750-150.850$ & 150.800 & $17 \mathrm{H}-4,50.00$ & Split core \\
\hline Excursion C $5 B n .2 n-2$ ? & & & & Not identified & & $151.300-151.400$ & 151.350 & $17 \mathrm{H}-4,105.00$ & Split core \\
\hline Excursion C $5 B n \cdot 2 n-3$ ? & & & & Not identified & & $152.200-152.300$ & 152.250 & $17 \mathrm{H}-5,45.00$ & Split core \\
\hline $\mathrm{C} 5 \mathrm{Bn} \cdot 2 \mathrm{n}-\mathrm{C} 5 \mathrm{Br}$ & 15.160 & Above 155.35 & & Above $17 \mathrm{H}-3,95.0$ & Split core & $153.150-153.225$ & 153.188 & $17 \mathrm{H}-5,138.75$ & Split core \\
\hline Excursion $\mathrm{C} 5 \mathrm{Br}-1$ ? & & & & Not identified & & $153.775-154.000$ & 153.888 & $17 \mathrm{H}-6,58.75$ & Split core \\
\hline Excursion $\mathrm{C} 5 \mathrm{Br}-2$ ? & & & & Not identified & & $154.250-154.350$ & 154.300 & $17 \mathrm{H}-6,100.00$ & Split core \\
\hline Excursion $\mathrm{C} 5 \mathrm{Br}-3$ ? & & & & Not identified & & $158.375-158.625$ & 158.500 & $18 \mathrm{H}-3,20.00$ & Split core \\
\hline
\end{tabular}




\begin{tabular}{|c|c|c|c|c|c|c|c|c|c|}
\hline \multirow[b]{2}{*}{ Polarity chron } & \multirow[b]{2}{*}{$\begin{array}{l}\text { Age } \\
(\mathrm{Ma})\end{array}$} & \multicolumn{4}{|c|}{ Hole U1335A } & \multicolumn{4}{|c|}{ Hole U1335B } \\
\hline & & $\begin{array}{l}\text { Range } \\
\operatorname{CSF}(\mathrm{m})\end{array}$ & $\begin{array}{l}\text { Best estimate } \\
\text { CSF }(m)\end{array}$ & $\begin{array}{l}\text { Best estimate core, } \\
\text { section, interval }(\mathrm{cm})\end{array}$ & $\begin{array}{l}\text { Measurement } \\
\text { type }\end{array}$ & $\begin{array}{l}\text { Range } \\
\text { CSF }(\mathrm{m})\end{array}$ & $\begin{array}{l}\text { Best estimate } \\
\text { CSF (m) }\end{array}$ & $\begin{array}{c}\text { Best estimate core, } \\
\text { section, interval }(\mathrm{cm})\end{array}$ & $\begin{array}{l}\text { Measurement } \\
\text { type }\end{array}$ \\
\hline Excursion C5Br-4 ? & & $156.750-156.850$ & 156.800 & $17 \mathrm{H}-4,90.0$ & Split core & $159.000-159.100$ & 159.050 & $18 \mathrm{H}-3,75.00$ & Split core \\
\hline Excursion C5Br-5 ? & & $157.050-157.100$ & 157.075 & $17 \mathrm{H}-4,117.5$ & Split core & $159.600-159.625$ & 159.613 & $18 \mathrm{H}-3,131.25$ & Split core \\
\hline Excursion C5Br-6? & & $158.500-158.550$ & 158.525 & $17 \mathrm{H}-5,112.5$ & Split core & $160.225-160.400$ & 160.313 & $18 \mathrm{H}-4,51.25$ & Split core \\
\hline Excursion C5Br-7? & & $159.250-159.250$ & 159.250 & $17 \mathrm{H}-6,35.0$ & Split core & $160.600-160.700$ & 160.650 & $18 \mathrm{H}-4,85.00$ & Split core \\
\hline Excursion C5Br-8? & & & & Not identified & & $161.050-161.225$ & 161.138 & $18 \mathrm{H}-4,133.75$ & Split core \\
\hline Excursion C5Br-9? & & $162.600-163.100$ & 162.850 & $18 \mathrm{H}-2,45.0$ & Split core & $162.725-163.250$ & 162.988 & $18 \mathrm{H}-6,25.00$ & Split core \\
\hline $\mathrm{C} 5 \mathrm{Br}-\mathrm{C} 5 \mathrm{Cn} .1 \mathrm{n}$ & 15.974 & $163.750-163.400$ & 163.575 & Between Sections $18 \mathrm{H}-2$ and 3 & Split core & $163.925-163.950$ & 163.938 & $18 \mathrm{H}-6,113.75$ & Split core \\
\hline Excursion $\mathrm{C} 5 \mathrm{Cn}-1$ ? & & $164.200-164.200$ & 164.200 & $18 \mathrm{H}-3,30.0$ & Split core & $164.075-164.150$ & 164.113 & $18 \mathrm{H}-6,131.25$ & Split core \\
\hline C5Cn.1n-C5Cn.1r & 16.268 & $169.100-169.150$ & 169.125 & $18 \mathrm{H}-6,72.5$ & Split core & $167.300-167.425$ & 167.363 & $19 \mathrm{H}-2,106.25$ & Split core \\
\hline Excursion C5Cn.1r-1? & & & & Not identified & & $167.675-167.725$ & 167.700 & $19 \mathrm{H}-2,140.00$ & Split core \\
\hline Excursion $\mathrm{C} 5 \mathrm{Cn} .1 \mathrm{r}-2$ ? & & & & Not identified & & $167.975-167.975$ & 167.975 & $19 \mathrm{H}-3,17.50$ & Split core \\
\hline C5Cn.1r-C5Cn.2n & 16.303 & Below 169.475 & & Below $18 \mathrm{H}-6,107.5$ & Split core & $168.700-168.725$ & 168.713 & $19 \mathrm{H}-3,91.25$ & Split core \\
\hline $\mathrm{C} 5 \mathrm{Cn} .2 \mathrm{n}-\mathrm{C} 5 \mathrm{Cn} .2 \mathrm{r}$ & 16.472 & Above 170.475 & & Above $19 \mathrm{H}-1,7.50$ & Split core & $169.675-169.725$ & 169.700 & $19 \mathrm{H}-4,40.00$ & Split core \\
\hline C5Cn.2r-C5Cn.3n & 16.543 & $171.725-171.775$ & 171.750 & $19 \mathrm{H}-1,135.00$ & Split core & $170.925-170.950$ & 170.938 & $19 \mathrm{H}-5,13.75$ & Split core \\
\hline $\mathrm{C} 5 \mathrm{Cn} \cdot 3 \mathrm{n}-\mathrm{C} 5 \mathrm{Cr}$ & 16.721 & $172.950-173.075$ & 173.013 & $19 \mathrm{H}-2,111.25$ & Split core & $172.100-172.125$ & 172.113 & $19 \mathrm{H}-5,131.25$ & Split core \\
\hline Excursion $\mathrm{C} 5 \mathrm{Cr}-1$ ? & & $176.650-176.700$ & 176.675 & $19 \mathrm{H}-5,27.50$ & Split core & & & Not identified & \\
\hline $\mathrm{C} 5 \mathrm{Cr}-\mathrm{C} 5 \mathrm{Dn}$ & 17.235 & $180.125-180.00$ & 180.063 & Between Sections $19 \mathrm{H}-7$ and $20 \mathrm{H}-1$ & Split core & $177.875-177.950$ & 177.913 & $20 \mathrm{H}-3,61.25$ & Split core \\
\hline C5Dn-C5Dr & 17.533 & $184.250-184.500$ & 184.375 & Between Sections $20 \mathrm{H}-3$ and 4 & Split core & $182.950-183.025$ & 182.988 & $20 \mathrm{H}-6,118.75$ & Split core \\
\hline C5Dr-C5Dr-1 & 17.825 & $187.250-187.300$ & 187.275 & $20 \mathrm{H}-5,137.5$ & Split core & $184.975-185.100$ & 185.038 & $21 \mathrm{H}-1,123.75$ & Split core \\
\hline C5Dr-1-C5Dr & 17.853 & $187.900-187.950$ & 187.925 & $20 \mathrm{H}-6,52.5$ & Split core & $185.600-185.650$ & 185.625 & $21 \mathrm{H}-2,32.50$ & Split core \\
\hline Excursion C5Dr-2? & & & & Not identified & & $187.850-187.900$ & 187.875 & $21 \mathrm{H}-3,107.50$ & Split core \\
\hline Excursion C5Dr-3? & & & & Not identified & & $188.525-188.600$ & 188.563 & $21 \mathrm{H}-4,26.25$ & Split core \\
\hline C5Dr-C5En & 18.056 & $192.300-192.500$ & 192.400 & Between Sections $21 \mathrm{H}-2$ and 3 & Split core & $191.400-191.450$ & 191.425 & $21 \mathrm{H}-6,12.50$ & Split core \\
\hline Excursion C5En-1 ? & & & & Not identified & & 198.175-198.475 & 198.325 & $22 \mathrm{H}-4,52.50$ & Split core \\
\hline C5En-C5Er & 18.524 & 198.65-199.85 & 199.250 & Between Sections $21 \mathrm{H}-7$ and $22 \mathrm{H}-1$ & Split core & $199.600-200.050$ & 199.825 & $22 \mathrm{H}-5,52.50$ & Split core \\
\hline Excursion C5Er-1? & & $202.800-202.850$ & 202.825 & $22 \mathrm{H}-3,92.50$ & Split core & & & Not identified & \\
\hline C5Er-C6n & 18.748 & $204.400-204.500$ & 204.450 & $22 \mathrm{H}-4,105.0$ & Split core & Below 202.60 & & Below $22 \mathrm{H}-7,30.00$ & \\
\hline C6n-C6r & 19.722 & Below 208.40 & & Below $22 \mathrm{H}-7,50.0$ & Split core & & & Not identified & \\
\hline
\end{tabular}

Table T21. Interstitial water data from squeezed whole-round samples, Site U1335. (See table notes.) (Continued on next page.)

\begin{tabular}{|c|c|c|c|c|c|c|c|c|c|c|c|c|c|c|c|c|c|c|}
\hline $\begin{array}{l}\text { Core, section, } \\
\text { interval }(\mathrm{cm})\end{array}$ & $\begin{array}{l}\text { Depth } \\
\text { CSF }(m)\end{array}$ & $\mathrm{pH}$ & $\begin{array}{l}\text { Alkalinity } \\
(\mathrm{mM})\end{array}$ & Salinity & $\begin{array}{c}\mathrm{Cl}^{-} \\
(\mathrm{mM})\end{array}$ & $\begin{array}{l}\mathrm{Na}^{+} \\
(\mathrm{mM})\end{array}$ & $\begin{array}{l}\mathrm{SO}_{4}{ }^{2-} \\
(\mathrm{mM})\end{array}$ & $\begin{array}{c}\mathrm{HPO}_{4}{ }^{2-} \\
(\mu \mathrm{M})\end{array}$ & $\begin{array}{c}\mathrm{H}_{4} \mathrm{SiO}_{4} \\
(\mu \mathrm{M})\end{array}$ & $\begin{array}{c}\mathrm{Mn}^{2+} \\
(\mu \mathrm{M})\end{array}$ & $\begin{array}{l}\mathrm{Fe}^{2+} \\
(\mu \mathrm{M})\end{array}$ & $\begin{array}{l}\mathrm{Ca}^{2+} \\
(\mathrm{mM})\end{array}$ & $\begin{array}{l}\mathrm{Mg}^{2+} \\
(\mathrm{mM})\end{array}$ & $\begin{array}{c}B \\
(\mu M)\end{array}$ & $\begin{array}{l}\mathrm{Sr}^{2+} \\
(\mu \mathrm{M})\end{array}$ & $\begin{array}{l}\mathrm{Ba}^{2+} \\
(\mu \mathrm{M})\end{array}$ & $\begin{array}{c}\mathrm{Li}^{+} \\
(\mu \mathrm{M})\end{array}$ & $\begin{array}{c}\mathrm{K}^{+} \\
(\mathrm{mM})\end{array}$ \\
\hline \multicolumn{19}{|l|}{ 320-U1335A- } \\
\hline $1 \mathrm{H}-2,145-150$ & 2.95 & 7.53 & 2.77 & - & 555 & 478 & 25.8 & 1.94 & 500 & 33.91 & BDL & 10.0 & 50.4 & 466 & 82 & 0.79 & 24.8 & 10.7 \\
\hline $1 \mathrm{H}-4,145-150$ & 5.95 & 7.54 & 2.65 & - & 559 & 484 & 27.9 & 1.72 & 519 & 37.93 & 5.72 & 10.5 & 50.7 & 466 & 89 & 1.84 & 23.7 & 10.7 \\
\hline $2 \mathrm{H}-2,145-150$ & 11.85 & 7.54 & 2.65 & - & 562 & 483 & 25.8 & 1.17 & 535 & 43.82 & $\mathrm{BDL}$ & 10.1 & 50.8 & 475 & 95 & 2.22 & 22.8 & 10.8 \\
\hline $2 \mathrm{H}-5,145-150$ & 16.35 & 7.52 & 2.78 & - & 560 & 482 & 26.6 & 1.14 & 590 & 36.91 & $\mathrm{BDL}$ & 10.4 & 50.8 & 477 & 103 & 2.23 & 22.3 & 10.8 \\
\hline $3 \mathrm{H}-2,145-150$ & 21.35 & 7.54 & 2.79 & - & 561 & 484 & 27.1 & 1.20 & 627 & 33.14 & BDL & 10.3 & 50.9 & 480 & 109 & 1.10 & 22.5 & 10.8 \\
\hline $3 \mathrm{H}-5,145-150$ & 25.85 & 7.54 & 2.80 & - & 563 & 483 & 26.0 & 1.21 & 626 & 29.59 & 0.55 & 10.5 & 51.1 & 476 & 110 & 1.30 & 21.4 & 10.8 \\
\hline $4 \mathrm{H}-2,145-150$ & 30.85 & 7.75 & 2.81 & - & 565 & 487 & 26.7 & 1.10 & 630 & 18.96 & BDL & 10.5 & 51.0 & 479 & 118 & 0.83 & 21.0 & 10.8 \\
\hline $4 \mathrm{H}-5,145-150$ & 35.35 & 7.52 & 2.84 & - & 563 & 484 & 26.2 & 1.08 & 654 & 13.75 & 1.05 & 10.5 & 50.9 & 486 & 124 & 0.83 & 20.8 & 11.4 \\
\hline $5 \mathrm{H}-2,145-150$ & 40.35 & 7.48 & 2.92 & - & 563 & 484 & 25.4 & 0.95 & 604 & 6.62 & BDL & 9.9 & 50.9 & 467 & 121 & 1.07 & 19.8 & 10.7 \\
\hline $6 \mathrm{H}-2,145-150$ & 49.85 & 7.52 & 2.92 & - & 565 & 487 & 26.7 & 1.16 & 615 & 4.59 & 0.53 & 10.4 & 51.0 & 470 & 139 & 0.71 & 18.9 & 10.6 \\
\hline $6 \mathrm{H}-5,145-150$ & 54.35 & 7.89 & 2.96 & - & 564 & 485 & 25.6 & 1.14 & 654 & 7.71 & 0.26 & 10.5 & 50.7 & 463 & 145 & 0.76 & 18.5 & 10.8 \\
\hline 7H-3, $140-150$ & 60.80 & 7.50 & 2.97 & - & 564 & 488 & 27.0 & 0.66 & 648 & 12.77 & 0.26 & 10.8 & 50.0 & 487 & 156 & 0.70 & 18.7 & 10.7 \\
\hline
\end{tabular}


Table T21 (continued).

\begin{tabular}{|c|c|c|c|c|c|c|c|c|c|c|c|c|c|c|c|c|c|c|}
\hline $\begin{array}{l}\text { Core, section, } \\
\text { interval }(\mathrm{cm})\end{array}$ & $\begin{array}{l}\text { Depth } \\
\text { CSF (m) }\end{array}$ & $\mathrm{pH}$ & $\begin{array}{l}\text { Alkalinity } \\
(\mathrm{mM})\end{array}$ & Salinity & $\begin{array}{c}\mathrm{Cl}^{-} \\
(\mathrm{mM})\end{array}$ & $\begin{array}{l}\mathrm{Na}^{+} \\
(\mathrm{mM})\end{array}$ & $\begin{array}{l}\mathrm{SO}_{4}{ }^{2-} \\
(\mathrm{mM})\end{array}$ & $\begin{array}{c}\mathrm{HPO}_{4}{ }^{2-} \\
(\mu \mathrm{M})\end{array}$ & $\begin{array}{c}\mathrm{H}_{4} \mathrm{SiO}_{4} \\
(\mu \mathrm{M})\end{array}$ & $\begin{array}{l}\mathrm{Mn}^{2+} \\
(\mu \mathrm{M})\end{array}$ & $\begin{array}{l}\mathrm{Fe}^{2+} \\
(\mu \mathrm{M})\end{array}$ & $\begin{array}{l}\mathrm{Ca}^{2+} \\
(\mathrm{mM})\end{array}$ & $\begin{array}{l}\mathrm{Mg}^{2+} \\
(\mathrm{mM})\end{array}$ & $\begin{array}{c}\text { B } \\
(\mu \mathrm{M})\end{array}$ & $\begin{array}{l}\mathrm{Sr}^{2+} \\
(\mu \mathrm{M})\end{array}$ & $\begin{array}{l}\mathrm{Ba}^{2+} \\
(\mu \mathrm{M})\end{array}$ & $\begin{array}{c}\mathrm{Li}^{+} \\
(\mu \mathrm{M})\end{array}$ & $\begin{array}{c}\mathrm{K}^{+} \\
(\mathrm{mM})\end{array}$ \\
\hline $8 \mathrm{H}-3,140-150$ & 70.30 & 7.48 & 3.02 & - & 562 & 485 & 25.4 & 0.66 & 603 & 7.66 & $\mathrm{BDL}$ & 10.2 & 49.9 & 456 & 153 & 1.05 & 16.3 & 10.5 \\
\hline $9 \mathrm{H}-3,145-150$ & 78.58 & 7.47 & 2.97 & - & 561 & 485 & 26.2 & 0.71 & 651 & 3.32 & 1.81 & 10.4 & 49.9 & 461 & 163 & 1.00 & 15.3 & 10.7 \\
\hline $10 \mathrm{H}-3,145-150$ & 89.35 & 7.42 & 3.40 & - & 560 & 479 & 23.6 & 1.01 & 622 & 1.18 & 1.53 & 10.4 & 50.1 & 472 & 168 & 1.16 & 14.9 & 10.7 \\
\hline $11 \mathrm{H}-2,140-150$ & 97.30 & 7.40 & 3.24 & - & 560 & 479 & 24.7 & 0.74 & 633 & 0.62 & 3.46 & 10.7 & 50.4 & 471 & 183 & $\mathrm{BDL}$ & 14.4 & 10.8 \\
\hline $12 \mathrm{H}-3,140-150$ & 108.30 & 7.42 & 3.13 & - & 561 & 482 & 25.5 & 0.75 & 586 & 0.45 & 3.88 & 10.9 & 50.1 & 471 & 198 & $\mathrm{BDL}$ & 13.3 & 10.6 \\
\hline $13 \mathrm{H}-3,140-150$ & 117.80 & 7.63 & 3.39 & - & 557 & 482 & 24.9 & 0.62 & 630 & 0.50 & 5.43 & 10.8 & 47.9 & 478 & 203 & $\mathrm{BDL}$ & 13.0 & 10.6 \\
\hline $14 \mathrm{H}-3,140-150$ & 127.30 & 7.42 & 3.20 & - & 559 & 480 & 25.0 & 0.56 & 642 & 0.52 & 6.26 & 10.9 & 49.6 & 471 & 205 & 1.00 & 11.9 & 10.7 \\
\hline $15 \mathrm{H}-3,140-150$ & 136.30 & 7.40 & 3.33 & - & 560 & 485 & 24.9 & 0.55 & 615 & 0.57 & 5.73 & 10.8 & 47.9 & 473 & 214 & 0.91 & 11.7 & 10.5 \\
\hline $16 \mathrm{H}-3,140-150$ & 146.30 & 7.57 & 6.50 & - & 558 & 487 & 25.5 & 0.47 & 650 & 0.93 & 5.23 & 11.0 & 48.1 & 467 & 212 & 0.77 & 10.5 & 10.6 \\
\hline $17 \mathrm{H}-3,140-150$ & 155.80 & 7.50 & 3.30 & - & 554 & 479 & 24.9 & 0.51 & 660 & 1.52 & 6.23 & 11.1 & 47.7 & 454 & 220 & 0.85 & 10.2 & 10.7 \\
\hline $18 \mathrm{H}-3,140-150$ & 165.30 & 7.44 & 3.38 & - & 556 & 482 & 25.5 & 0.59 & 637 & 2.78 & 2.80 & 11.0 & 47.8 & 461 & 223 & 0.47 & 9.3 & 10.7 \\
\hline $19 \mathrm{H}-3,140-150$ & 174.80 & 7.46 & 3.35 & - & 559 & 481 & 23.5 & 0.59 & 722 & 4.32 & 0.31 & 11.4 & 47.3 & 457 & 228 & 1.17 & 9.2 & 10.6 \\
\hline $20 \mathrm{H}-3,140-150$ & 184.30 & 7.47 & 3.31 & - & 559 & 483 & 24.8 & 0.56 & 692 & 4.69 & 1.06 & 11.3 & 47.9 & 476 & 241 & $\mathrm{BDL}$ & 8.7 & 10.8 \\
\hline $21 \mathrm{H}-3,140-150$ & 193.80 & 7.42 & 3.11 & - & 558 & 479 & 23.2 & 0.51 & 770 & 3.09 & 1.54 & 11.2 & 47.4 & 465 & 243 & $\mathrm{BDL}$ & 8.1 & 10.7 \\
\hline $22 \mathrm{H}-3,140-150$ & 203.30 & 7.24 & 3.13 & - & 558 & 491 & 25.2 & 0.57 & 709 & 2.06 & 1.98 & 10.5 & 44.4 & 466 & 248 & 1.18 & 8.0 & 10.5 \\
\hline $23 \mathrm{H}-3,140-150$ & 212.80 & 7.51 & 3.09 & - & 558 & 483 & 25.0 & $\mathrm{BDL}$ & 781 & 1.24 & 3.79 & 11.3 & 47.1 & 461 & 242 & 1.00 & 8.3 & 10.7 \\
\hline $24 \mathrm{H}-3,140-150$ & 222.30 & 7.43 & 3.22 & - & 562 & 481 & 22.9 & 0.46 & 707 & 0.76 & 2.98 & 11.4 & 47.9 & 474 & 244 & $\mathrm{BDL}$ & 6.9 & 10.8 \\
\hline $25 \mathrm{H}-3,140-150$ & 231.80 & 7.44 & 3.49 & - & 563 & 488 & 24.9 & 0.48 & 703 & 0.82 & 2.34 & 11.1 & 47.4 & 460 & 242 & 0.88 & 6.4 & 10.5 \\
\hline $26 \mathrm{H}-3,140-150$ & 241.30 & 7.46 & 3.35 & - & 558 & 478 & 23.2 & $\mathrm{BDL}$ & 733 & 0.71 & 4.30 & 11.6 & 48.0 & 472 & 249 & $\mathrm{BDL}$ & 5.6 & 10.6 \\
\hline $27 \mathrm{H}-3,140-150$ & 250.80 & 7.44 & 3.26 & - & 557 & 477 & 23.1 & 0.44 & 71 & 0.61 & 3.15 & 11.3 & 48.0 & 479 & 242 & $\mathrm{BDL}$ & 5.6 & 10.7 \\
\hline $28 \mathrm{H}-3,140-150$ & 260.30 & 7.42 & 3.26 & - & 557 & 478 & 23.2 & 0.41 & 710 & 0.55 & 3.62 & 11.1 & 47.7 & 467 & 240 & $\mathrm{BDL}$ & 5.3 & 10.7 \\
\hline $29 \mathrm{H}-3,140-150$ & 269.80 & 7.57 & 3.50 & - & 556 & 480 & 25.1 & 0.49 & 823 & & 3.84 & 11.8 & 47.5 & 470 & 195 & $\mathrm{BDL}$ & 13.2 & 10.7 \\
\hline $30 \mathrm{H}-3,140-150$ & 279.30 & 7.39 & 3.71 & - & 559 & 482 & 23.5 & 0.49 & 722 & 0.59 & 5.37 & 11.0 & 47.5 & 467 & 238 & $\mathrm{BDL}$ & 5.3 & 10.6 \\
\hline $31 \mathrm{H}-3,140-150$ & 288.80 & 7.37 & 3.54 & - & 561 & 482 & 23.4 & 0.49 & 717 & 0.30 & 3.51 & 11.3 & 48.0 & 451 & 232 & 0.87 & 4.5 & 10.6 \\
\hline $32 \mathrm{H}-3,140-150$ & 298.30 & 7.53 & 3.54 & - & 558 & 479 & 23.0 & 0.48 & 731 & 0.30 & 4.39 & 11.3 & 47.7 & 456 & 235 & $\mathrm{BDL}$ & 4.3 & 10.7 \\
\hline $33 \mathrm{H}-3,140-150$ & 307.80 & 7.60 & 3.54 & - & 561 & 490 & 23.3 & 0.4 & 744 & 0.27 & 3.47 & 10.4 & 44.8 & 451 & 229 & $\mathrm{BDL}$ & 4.7 & 10.4 \\
\hline $34 \mathrm{H}-3,140-150$ & 315.90 & 7.56 & 3.61 & - & 560 & 486 & 24.2 & $\mathrm{BDL}$ & 759 & 0.37 & 3.63 & 11.0 & 46.7 & 471 & 234 & 0.71 & 7.5 & 10.5 \\
\hline $39 X-3,140-150$ & 365.10 & 7.42 & 3.07 & - & 563 & 483 & 25.9 & 0.52 & 686 & 0.34 & 1.11 & 11.1 & 50.8 & 467 & 186 & $\mathrm{BDL}$ & 8.6 & 10.7 \\
\hline $40 X-3,140-150$ & 374.60 & 7.40 & 2.78 & - & 562 & 499 & 25.7 & 0.52 & 65 & 0.49 & $\mathrm{BDL}$ & 9.5 & 43.8 & 437 & 161 & 1.02 & 9.7 & 9.9 \\
\hline $41 X-3,140-150$ & 384.10 & 7.73 & 3.21 & - & 562 & 481 & 24.4 & 0.48 & 678 & $\mathrm{BDL}$ & 0.19 & 10.7 & 50.2 & 461 & 161 & 0.74 & 12.3 & 10.7 \\
\hline $42 X-3,140-150$ & 393.60 & 7.46 & 2.83 & - & 564 & 481 & 25.4 & 0.49 & 690 & 0.16 & 0.21 & 12.1 & 50.9 & 468 & 145 & $\mathrm{BDL}$ & 15.0 & 10.6 \\
\hline $43 X-3,140-150$ & 403.20 & 7.50 & 2.73 & - & 562 & 493 & 24.0 & $\mathrm{BDL}$ & 665 & & 0.19 & 9.5 & 45.1 & 442 & 115 & 0.85 & 19.4 & 10.3 \\
\hline $44 X-3,140-150$ & 412.80 & 7.43 & 2.54 & - & 561 & 485 & 24.1 & $\mathrm{BDL}$ & 719 & 0.11 & 0.29 & 10.0 & 48.0 & 458 & 101 & 1.12 & 32.4 & 10.5 \\
\hline \multicolumn{19}{|l|}{ 320-U1335B- } \\
\hline $36 \mathrm{H}-3,140-150$ & 330.80 & 7.59 & 4.32 & - & 560 & 486 & 24.9 & 0.49 & 754 & BDL & 2.88 & 10.9 & 47.9 & 443 & 208 & BDL & 4.7 & 10.6 \\
\hline $37 \mathrm{H}-2,140-150$ & 338.70 & 7.60 & 3.57 & - & 557 & 474 & 23.6 & $\mathrm{BDL}$ & 743 & $\mathrm{BDL}$ & 3.22 & 11.5 & 50.0 & 442 & 212 & $\mathrm{BDL}$ & 6.1 & 10.6 \\
\hline $39 \mathrm{H}-3,140-150$ & 357.20 & 7.51 & 3.52 & - & 558 & 475 & 23.8 & - & 739 & $\mathrm{BDL}$ & 3.17 & 11.1 & 50.3 & 454 & 196 & $\mathrm{BDL}$ & 7.3 & 10.7 \\
\hline
\end{tabular}

Notes: $\mathrm{BDL}=$ below detection limit $\left(\mathrm{HPO}_{4}{ }^{2-}=0.4 \mu \mathrm{M}, \mathrm{Mn}^{2+}=0.1 \mu \mathrm{M}, \mathrm{Fe}^{2+}=0.2 \mu \mathrm{M}, \mathrm{B}=1.4 \mu \mathrm{M}, \mathrm{Sr}^{2+}=0.2 \mu \mathrm{M}, \mathrm{Ba}^{2+}=0.7 \mu \mathrm{M}, \mathrm{Li}^{+}=0.4 \mu \mathrm{M}\right)$. $\mathrm{H}_{4} \mathrm{SiO}{ }_{4}$ values measured by different techniques during Expeditions 320 and 321 disagree significantly, especially for low values. Therefore, caution should be used concerning the $\mathrm{H}_{4} \mathrm{SiO}_{4}$ data and comparison between the different expeditions. 
Table T22. Inorganic geochemistry of solid samples, Site U1335. (See table notes.)

\begin{tabular}{|c|c|c|c|c|c|c|c|c|c|c|c|c|c|c|c|c|c|c|c|}
\hline \multirow{2}{*}{$\begin{array}{l}\text { Core, section, } \\
\text { interval }(\mathrm{cm})\end{array}$} & \multirow{2}{*}{$\begin{array}{l}\text { Depth } \\
\text { CSF (m) }\end{array}$} & \multicolumn{10}{|c|}{ Major element oxide (wt\%) } & \multicolumn{8}{|c|}{ Trace element (ppm) } \\
\hline & & $\mathrm{SiO}_{2}$ & $\mathrm{Al}_{2} \mathrm{O}_{3}$ & $\mathrm{Fe}_{2} \mathrm{O}_{3} \mathrm{~T}$ & $\mathrm{MnO}$ & $\mathrm{MgO}$ & $\mathrm{CaO}$ & $\mathrm{Na}_{2} \mathrm{O}$ & $\mathrm{K}_{2} \mathrm{O}$ & $\mathrm{TiO}_{2}$ & $\mathrm{P}_{2} \mathrm{O}_{5}$ & $\mathrm{Ba}$ & $\mathrm{Cr}$ & $\mathrm{Cu}$ & Sc & $\mathrm{Sr}$ & $\mathrm{V}$ & $\mathrm{Y}$ & $\mathrm{Zr}$ \\
\hline \multicolumn{20}{|l|}{ 320-U1335A- } \\
\hline $1 \mathrm{H}-3,65-66$ & 3.65 & 21.76 & 3.56 & 2.31 & $(0.40)$ & 1.15 & 31.2 & 3.06 & 0.88 & 0.17 & 0.30 & 3931 & 18.2 & 271 & 9.7 & 1031 & 20.6 & 54.9 & 65.3 \\
\hline $7 \mathrm{H}-3,65-66$ & 60.05 & 34.22 & 2.96 & 2.66 & $(0.68)$ & 1.46 & 26.1 & 3.34 & 0.76 & 0.14 & 0.49 & 7372 & 11.1 & 631 & 14.3 & 1448 & 10.8 & 151.4 & 91.7 \\
\hline $12 \mathrm{H}-7,40-41$ & 113.30 & 6.85 & 0.42 & 0.54 & 0.05 & 0.37 & 40.5 & 1.40 & 0.24 & 0.02 & 0.20 & 2254 & 51.0 & 68 & 1.1 & 2061 & BDL & 23.3 & 24.7 \\
\hline $18 \mathrm{H}-2,65-66$ & 163.05 & 7.76 & 0.06 & 0.43 & 0.10 & 0.37 & 41.4 & 1.54 & 0.11 & 0.00 & 0.24 & 1052 & BDL & 88 & 0.6 & 1526 & BDL & 10.0 & 15.2 \\
\hline $19 \mathrm{H}-2,65-65$ & 172.55 & 29.14 & 1.73 & 1.83 & 0.09 & 0.81 & 31.7 & 2.14 & 0.55 & 0.07 & 0.31 & 5692 & 6.7 & 312 & 5.4 & 1640 & BDL & 50.0 & 43.0 \\
\hline $22 \mathrm{H}-2,65-66$ & 201.05 & 9.10 & 0.08 & 0.47 & 0.08 & 0.32 & 36.7 & 1.07 & 0.09 & 0.00 & 0.18 & 1591 & BDL & 52 & $\mathrm{BDL}$ & 1366 & BDL & 13.7 & 13.7 \\
\hline $30 \mathrm{H}-5,65-66$ & 281.55 & 6.01 & BDL & 0.40 & 0.04 & 0.28 & 40.5 & 0.93 & 0.07 & 0.00 & 0.16 & 1369 & BDL & 35 & BDL & 1668 & BDL & 10.3 & 12.0 \\
\hline $34 \mathrm{H}-6,65-66$ & 319.65 & 5.93 & BDL & 0.41 & 0.04 & 0.26 & 42.5 & 0.98 & 0.07 & 0.00 & 0.18 & 1524 & $\mathrm{BDL}$ & 44 & $\mathrm{BDL}$ & 1927 & BDL & 11.0 & 12.6 \\
\hline $41 X-6,33-35$ & 387.13 & 9.03 & 0.17 & 0.45 & 0.05 & 0.42 & 40.6 & 0.86 & 0.08 & 0.01 & $\mathrm{BDL}$ & 1769 & 89.5 & 69 & $\mathrm{BDL}$ & 1942 & BDL & 12.2 & 15.3 \\
\hline
\end{tabular}

Notes: $\mathrm{BDL}=$ below detection limit $\left(\mathrm{SiO}_{2}=3.5 \mathrm{wt} \%, \mathrm{Al}_{2} \mathrm{O}_{3}=0.04 \mathrm{wt} \%, \mathrm{Fe}_{2} \mathrm{O}_{3} \mathrm{~T}=0.003 \mathrm{wt} \%, \mathrm{MnO}=0.0004 \mathrm{wt} \%, \mathrm{MgO}=0.007 \mathrm{wt} \%, \mathrm{CaO}=0.1\right.$ wt $\%, \mathrm{Na} 2 \mathrm{O}=0.02 \mathrm{wt} \%, \mathrm{~K}, \mathrm{O}=0.004 \mathrm{wt} \%$, $\left.\mathrm{TiO}_{2}=0.001 \mathrm{wt} \%, \mathrm{P}_{2} \mathrm{O}_{5}=0.1 \mathrm{wt} \%, \mathrm{Ba}=28 \mathrm{wt} \%, \mathrm{Cr}=5 \mathrm{wt} \%, \mathrm{Cu}=16 \mathrm{wt} \%, \mathrm{Sc}=0.4 \mathrm{wt} \%, \mathrm{Sr}=3 \mathrm{wt} \%, \mathrm{~V}=4 \mathrm{wt} \%, \mathrm{Y}=1.7 \mathrm{wt} \%, \mathrm{Zr}=4 \mathrm{wt} \%\right)$. See Table T9 for maximum values of calibration. 
Table T23. Calcium carbonate and organic carbon data, Site U1335. (See table notes). (Continued on next two pages.)

\begin{tabular}{|c|c|c|c|c|c|}
\hline \multirow{2}{*}{$\begin{array}{l}\text { Core, section, } \\
\text { interval }(\mathrm{cm})\end{array}$} & \multirow{2}{*}{$\begin{array}{l}\text { Depth CSF } \\
\quad(\mathrm{m})\end{array}$} & \multicolumn{4}{|c|}{ Carbon (wt\%) } \\
\hline & & $\mathrm{CaCO}_{3}$ & IC & TC & TOC \\
\hline \multicolumn{6}{|l|}{ 320-U1335A- } \\
\hline $1 \mathrm{H}-1,105-106$ & 1.05 & 68.7 & 8.25 & 8.52 & 0.10 \\
\hline $1 \mathrm{H}-2,65-66$ & 2.15 & 58.8 & 7.05 & ND & ND \\
\hline $1 \mathrm{H}-3,65-66$ & 3.65 & 59.7 & 7.17 & ND & ND \\
\hline $1 \mathrm{H}-4,65-66$ & 5.15 & 69.9 & 8.39 & ND & ND \\
\hline $1 \mathrm{H}-5,65-66$ & 6.65 & 58.7 & 7.05 & ND & ND \\
\hline $1 \mathrm{H}-6,65-66$ & 7.85 & 62.4 & 7.49 & ND & ND \\
\hline $2 \mathrm{H}-1,65-66$ & 9.55 & 41.5 & 4.98 & ND & ND \\
\hline $2 \mathrm{H}-2,65-66$ & 11.05 & 62.0 & 7.44 & ND & ND \\
\hline $2 \mathrm{H}-3,65-66$ & 12.55 & 67.8 & 8.14 & ND & ND \\
\hline $2 \mathrm{H}-4,65-66$ & 14.05 & 77.0 & 9.24 & ND & ND \\
\hline $2 \mathrm{H}-5,65-66$ & 15.55 & 62.2 & 7.46 & ND & ND \\
\hline $2 \mathrm{H}-6,65-66$ & 17.05 & 40.9 & 4.91 & ND & ND \\
\hline $2 \mathrm{H}-7,65-66$ & 18.55 & 24.4 & 2.93 & ND & ND \\
\hline $3 \mathrm{H}-1,65-66$ & 19.05 & 30.8 & 3.70 & 3.98 & 0.10 \\
\hline $3 \mathrm{H}-2,65-66$ & 20.55 & 41.2 & 4.95 & ND & ND \\
\hline $3 \mathrm{H}-3,65-66$ & 22.05 & 61.1 & 7.34 & ND & ND \\
\hline $3 \mathrm{H}-4,65-66$ & 23.55 & 59.3 & 7.12 & ND & ND \\
\hline $3 \mathrm{H}-5,65-66$ & 25.05 & 42.3 & 5.08 & ND & ND \\
\hline $3 \mathrm{H}-6,65-66$ & 26.55 & 69.0 & 8.29 & ND & ND \\
\hline $3 \mathrm{H}-7,25-26$ & 27.65 & 62.1 & 7.46 & ND & ND \\
\hline $4 \mathrm{H}-1,115-116$ & 29.05 & 38.0 & 4.56 & ND & ND \\
\hline $4 \mathrm{H}-2,64-65$ & 30.04 & 22.5 & 2.71 & ND & ND \\
\hline $4 \mathrm{H}-3,64-65$ & 31.54 & 65.8 & 7.89 & ND & ND \\
\hline $4 \mathrm{H}-4,64-65$ & 33.04 & 59.0 & 7.08 & ND & ND \\
\hline $4 \mathrm{H}-5,64-65$ & 34.54 & 65.1 & 7.81 & ND & ND \\
\hline $4 \mathrm{H}-6,64-65$ & 36.04 & 61.4 & 7.37 & ND & ND \\
\hline $4 \mathrm{H}-7,40-41$ & 37.30 & 58.5 & 7.02 & ND & ND \\
\hline $5 \mathrm{H}-1,64-65$ & 38.04 & 80.1 & 9.62 & 9.89 & 0.05 \\
\hline $5 \mathrm{H}-2,64-65$ & 39.54 & 87.8 & 10.54 & ND & ND \\
\hline $5 \mathrm{H}-3,64-65$ & 41.04 & 65.1 & 7.81 & ND & ND \\
\hline $5 \mathrm{H}-4,64-65$ & 42.54 & 73.6 & 8.83 & ND & ND \\
\hline $5 \mathrm{H}-5,64-65$ & 44.04 & 82.3 & 9.88 & ND & ND \\
\hline $5 \mathrm{H}-6,64-65$ & 45.54 & 35.5 & 4.26 & ND & ND \\
\hline $6 \mathrm{H}-1,65-66$ & 47.55 & 80.6 & 9.68 & ND & ND \\
\hline $6 \mathrm{H}-2,65-66$ & 49.05 & 83.1 & 9.97 & ND & ND \\
\hline $6 \mathrm{H}-3,65-66$ & 50.55 & 86.5 & 10.38 & ND & ND \\
\hline $6 \mathrm{H}-4,65-66$ & 52.05 & 80.8 & 9.70 & ND & ND \\
\hline $6 \mathrm{H}-5,65-66$ & 53.55 & 83.8 & 10.06 & ND & ND \\
\hline $6 \mathrm{H}-6,65-66$ & 55.05 & 29.9 & 3.59 & ND & ND \\
\hline $6 \mathrm{H}-7,20-21$ & 56.10 & 46.6 & 5.60 & ND & ND \\
\hline $7 \mathrm{H}-1,65-66$ & 57.05 & 12.6 & 1.51 & ND & ND \\
\hline $7 \mathrm{H}-1,65-66$ & 57.05 & 12.8 & 1.54 & 1.57 & 0.10 \\
\hline $7 \mathrm{H}-2,65-66$ & 58.55 & 16.0 & 1.92 & ND & ND \\
\hline $7 \mathrm{H}-3,65-66$ & 60.05 & 44.4 & 5.33 & ND & ND \\
\hline $7 \mathrm{H}-4,65-65$ & 61.55 & 36.6 & 4.39 & ND & ND \\
\hline $7 \mathrm{H}-5,65-65$ & 63.05 & 47.2 & 5.67 & ND & ND \\
\hline $7 \mathrm{H}-6,65-65$ & 64.55 & 79.5 & 9.54 & ND & ND \\
\hline $7 \mathrm{H}-7,20-21$ & 65.60 & 51.1 & 6.13 & ND & ND \\
\hline $8 \mathrm{H}-1,65-66$ & 66.55 & 72.0 & 8.65 & ND & ND \\
\hline $8 \mathrm{H}-2,65-66$ & 68.05 & 85.6 & 10.28 & ND & ND \\
\hline $8 \mathrm{H}-3,65-66$ & 69.55 & 89.4 & 10.73 & ND & ND \\
\hline $8 \mathrm{H}-4,65-66$ & 71.05 & 88.1 & 10.57 & ND & ND \\
\hline $8 \mathrm{H}-5,65-66$ & 72.55 & 80.6 & 9.68 & ND & ND \\
\hline $8 \mathrm{H}-6,65-66$ & 74.05 & 83.3 & 10.00 & ND & ND \\
\hline $8 \mathrm{H}-7,30-31$ & 75.20 & 87.0 & 10.44 & ND & ND \\
\hline $9 \mathrm{H}-1,65-66$ & 76.05 & 87.6 & 10.52 & 10.59 & 0.04 \\
\hline $9 \mathrm{H}-2,65-66$ & 77.55 & 86.4 & 10.37 & ND & ND \\
\hline $9 \mathrm{H}-3,65-66$ & 79.05 & 86.2 & 10.34 & ND & ND \\
\hline $9 \mathrm{H}-4,65-66$ & 80.55 & 80.6 & 9.68 & ND & ND \\
\hline $9 \mathrm{H}-5,65-66$ & 82.05 & 75.9 & 9.11 & ND & ND \\
\hline $9 \mathrm{H}-6,65-66$ & 83.55 & 88.0 & 10.56 & ND & ND \\
\hline $9 \mathrm{H}-7,15-16$ & 84.55 & 81.5 & 9.78 & ND & ND \\
\hline $10 \mathrm{H}-1,65-66$ & 85.55 & 87.2 & 10.47 & ND & ND \\
\hline $10 \mathrm{H}-2,65-66$ & 87.05 & 89.5 & 10.75 & ND & ND \\
\hline $10 \mathrm{H}-3,65-66$ & 88.55 & 91.2 & 10.94 & ND & ND \\
\hline $10 \mathrm{H}-4,65-66$ & 90.05 & 89.0 & 10.68 & ND & ND \\
\hline
\end{tabular}

\begin{tabular}{|c|c|c|c|c|c|}
\hline \multirow{2}{*}{$\begin{array}{l}\text { Core, section, } \\
\text { interval }(\mathrm{cm})\end{array}$} & \multirow{2}{*}{$\begin{array}{l}\text { Depth CSF } \\
\quad(\mathrm{m})\end{array}$} & \multicolumn{4}{|c|}{ Carbon (wt\%) } \\
\hline & & $\mathrm{CaCO}_{3}$ & IC & $\mathrm{TC}$ & TOC \\
\hline $10 \mathrm{H}-5,65-66$ & 91.55 & 87.6 & 10.52 & ND & ND \\
\hline $10 \mathrm{H}-6,65-66$ & 93.05 & 89.7 & 10.77 & ND & ND \\
\hline $10 \mathrm{H}-7,55-56$ & 94.45 & 89.2 & 10.71 & ND & ND \\
\hline $11 \mathrm{H}-1,65-66$ & 95.05 & 82.8 & 9.93 & 10.20 & 0.04 \\
\hline $11 \mathrm{H}-2,65-66$ & 96.55 & 79.1 & 9.49 & ND & ND \\
\hline $11 \mathrm{H}-3,65-66$ & 98.05 & 85.9 & 10.31 & ND & ND \\
\hline $11 \mathrm{H}-4,65-66$ & 99.55 & 88.2 & 10.58 & ND & ND \\
\hline $11 \mathrm{H}-5,65-66$ & 101.05 & 84.7 & 10.17 & ND & ND \\
\hline $11 \mathrm{H}-6,65-66$ & 102.55 & 81.1 & 9.73 & ND & ND \\
\hline $11 \mathrm{H}-7,20-21$ & 103.60 & 84.9 & 10.19 & ND & ND \\
\hline $12 \mathrm{H}-1,64-65$ & 104.54 & 85.2 & 10.23 & ND & ND \\
\hline $12 \mathrm{H}-2,64-65$ & 106.04 & 88.2 & 10.59 & ND & ND \\
\hline $12 \mathrm{H}-3,64-65$ & 107.54 & 86.5 & 10.39 & ND & ND \\
\hline $12 \mathrm{H}-4,64-65$ & 109.04 & 82.8 & 9.94 & ND & ND \\
\hline $12 \mathrm{H}-5,64-65$ & 110.54 & 87.9 & 10.55 & ND & ND \\
\hline $12 \mathrm{H}-6,40-41$ & 111.80 & 90.1 & 10.82 & ND & ND \\
\hline $12 \mathrm{H}-7,40-41$ & 113.30 & 83.7 & 10.05 & ND & ND \\
\hline $13 \mathrm{H}-1,84-85$ & 114.24 & 88.5 & 10.63 & 10.92 & 0.04 \\
\hline $13 \mathrm{H}-2,64-65$ & 115.54 & 84.8 & 10.18 & ND & ND \\
\hline $13 \mathrm{H}-3,64-65$ & 117.04 & 86.9 & 10.44 & ND & ND \\
\hline $13 \mathrm{H}-4,64-65$ & 118.54 & 90.0 & 10.80 & ND & ND \\
\hline $13 \mathrm{H}-5,64-65$ & 120.04 & 76.3 & 9.16 & ND & ND \\
\hline $13 \mathrm{H}-6,64-65$ & 121.54 & 78.4 & 9.41 & ND & ND \\
\hline $13 \mathrm{H}-7,40-41$ & 122.80 & 90.1 & 10.82 & ND & ND \\
\hline $14 \mathrm{H}-1,65-66$ & 123.55 & 90.9 & 10.91 & ND & ND \\
\hline $14 \mathrm{H}-2,65-66$ & 125.05 & 77.9 & 9.35 & ND & ND \\
\hline $14 \mathrm{H}-3,65-66$ & 126.55 & 84.1 & 10.10 & ND & ND \\
\hline $14 \mathrm{H}-4,65-66$ & 128.05 & 85.5 & 10.27 & ND & ND \\
\hline $14 \mathrm{H}-5,65-66$ & 129.55 & 81.2 & 9.75 & ND & ND \\
\hline $14 \mathrm{H}-6,65-66$ & 131.05 & 91.6 & 11.00 & ND & ND \\
\hline $14 \mathrm{H}-7,50-51$ & 132.40 & 81.0 & 9.72 & ND & ND \\
\hline $15 \mathrm{H}-1,10-11$ & 133.40 & 86.7 & 10.41 & 10.63 & 0.04 \\
\hline $15 \mathrm{H}-2,50-51$ & 134.40 & 82.7 & 9.93 & ND & ND \\
\hline $15 \mathrm{H}-3,50-51$ & 135.40 & 86.3 & 10.36 & ND & ND \\
\hline $15 \mathrm{H}-4,65-66$ & 137.05 & 88.3 & 10.60 & ND & ND \\
\hline $15 \mathrm{H}-5,65-66$ & 138.55 & 86.7 & 10.40 & ND & ND \\
\hline $15 \mathrm{H}-6,65-66$ & 140.05 & 82.3 & 9.89 & ND & ND \\
\hline $15 \mathrm{H}-7,65-66$ & 141.55 & 88.8 & 10.66 & ND & ND \\
\hline $16 \mathrm{H}-1,65-66$ & 142.55 & 80.3 & 9.64 & ND & ND \\
\hline $16 \mathrm{H}-2,65-66$ & 144.05 & 87.9 & 10.56 & ND & ND \\
\hline $16 \mathrm{H}-3,65-66$ & 145.55 & 77.2 & 9.27 & ND & ND \\
\hline $16 \mathrm{H}-4,65-66$ & 147.05 & 86.6 & 10.40 & ND & ND \\
\hline $17 \mathrm{H}-1,65-66$ & 152.05 & 73.0 & 8.76 & 8.99 & 0.05 \\
\hline $17 \mathrm{H}-2,65-66$ & 153.55 & 81.3 & 9.75 & ND & ND \\
\hline $17 \mathrm{H}-3,65-66$ & 155.05 & 81.0 & 9.72 & ND & ND \\
\hline $17 \mathrm{H}-4,65-66$ & 156.55 & 91.9 & 11.03 & ND & ND \\
\hline $17 \mathrm{H}-5,65-66$ & 158.05 & 59.6 & 7.15 & ND & ND \\
\hline $17 \mathrm{H}-6,55-56$ & 159.45 & 62.5 & 7.50 & ND & ND \\
\hline $17 \mathrm{H}-7,40-41$ & 160.80 & 76.9 & 9.23 & ND & ND \\
\hline $18 \mathrm{H}-1,65-66$ & 161.55 & 82.7 & 9.93 & ND & ND \\
\hline $18 \mathrm{H}-2,65-66$ & 163.05 & 84.1 & 10.10 & ND & ND \\
\hline $18 \mathrm{H}-3,65-66$ & 164.55 & 84.0 & 10.08 & ND & ND \\
\hline $18 \mathrm{H}-4,65-66$ & 166.05 & 82.6 & 9.92 & ND & ND \\
\hline $18 \mathrm{H}-5,65-66$ & 167.55 & 86.2 & 10.35 & ND & ND \\
\hline $18 \mathrm{H}-6,65-66$ & 169.05 & 74.9 & 8.99 & ND & ND \\
\hline $19 \mathrm{H}-1,65-67$ & 171.05 & 83.8 & 10.07 & 10.31 & 0.04 \\
\hline $19 \mathrm{H}-2,65-65$ & 172.55 & 55.8 & 6.70 & ND & ND \\
\hline $19 \mathrm{H}-3,65-65$ & 174.05 & 73.3 & 8.80 & ND & ND \\
\hline $19 \mathrm{H}-4,65-65$ & 175.55 & 71.8 & 8.62 & ND & ND \\
\hline $19 \mathrm{H}-5,65-65$ & 177.05 & 66.6 & 7.99 & ND & ND \\
\hline $19 \mathrm{H}-6,65-65$ & 178.55 & 60.0 & 7.21 & ND & ND \\
\hline $19 \mathrm{H}-7,40-41$ & 179.80 & 68.1 & 8.17 & ND & ND \\
\hline $20 \mathrm{H}-1,65-66$ & 180.55 & 83.1 & 9.98 & ND & ND \\
\hline $20 \mathrm{H}-2,65-66$ & 182.05 & 81.3 & 9.76 & ND & ND \\
\hline $20 \mathrm{H}-3,65-66$ & 183.55 & 80.1 & 9.62 & ND & ND \\
\hline $20 \mathrm{H}-4,65-66$ & 185.05 & 85.2 & 10.22 & ND & ND \\
\hline $20 \mathrm{H}-5,65-66$ & 186.55 & 74.5 & 8.94 & ND & ND \\
\hline
\end{tabular}


Table T23 (continued). (Continued on next page.)

\begin{tabular}{|c|c|c|c|c|c|}
\hline \multirow{2}{*}{$\begin{array}{l}\text { Core, section, } \\
\text { interval }(\mathrm{cm})\end{array}$} & \multirow{2}{*}{$\begin{array}{l}\text { Depth CSF } \\
(\mathrm{m})\end{array}$} & \multicolumn{4}{|c|}{ Carbon (wt\%) } \\
\hline & & $\mathrm{CaCO}_{3}$ & IC & $\mathrm{TC}$ & TOC \\
\hline $20 \mathrm{H}-6,65-66$ & 188.05 & 66.0 & 7.92 & ND & ND \\
\hline $20 \mathrm{H}-7,40-41$ & 189.30 & 67.5 & 8.11 & ND & ND \\
\hline $21 \mathrm{H}-1,65-66$ & 190.05 & 85.9 & 10.32 & 10.63 & 0.04 \\
\hline $21 \mathrm{H}-2,65-66$ & 191.55 & 86.5 & 10.38 & ND & ND \\
\hline $21 \mathrm{H}-3,65-66$ & 193.05 & 81.6 & 9.79 & ND & ND \\
\hline $21 \mathrm{H}-4,65-66$ & 194.55 & 81.7 & 9.81 & ND & ND \\
\hline $21 \mathrm{H}-5,65-66$ & 196.05 & 83.1 & 9.97 & ND & ND \\
\hline $21 \mathrm{H}-6,65-66$ & 197.55 & 84.6 & 10.16 & ND & ND \\
\hline $21 \mathrm{H}-7,20-21$ & 198.50 & 84.9 & 10.19 & ND & ND \\
\hline $22 \mathrm{H}-1,100-101$ & 199.90 & 80.9 & 9.72 & ND & ND \\
\hline $22 \mathrm{H}-2,65-66$ & 201.05 & 83.6 & 10.04 & ND & ND \\
\hline $22 \mathrm{H}-3,65-66$ & 202.55 & 79.5 & 9.54 & ND & ND \\
\hline $22 \mathrm{H}-4,65-66$ & 204.05 & 65.8 & 7.90 & ND & ND \\
\hline $22 \mathrm{H}-5,65-66$ & 205.55 & 85.8 & 10.30 & ND & ND \\
\hline $22 \mathrm{H}-6,65-66$ & 207.05 & 77.2 & 9.27 & ND & ND \\
\hline $22 \mathrm{H}-7,30-31$ & 208.20 & 84.5 & 10.14 & ND & ND \\
\hline $23 \mathrm{H}-2,65-66$ & 210.55 & 85.0 & 10.20 & 10.40 & 0.04 \\
\hline $23 \mathrm{H}-3,65-66$ & 212.05 & 87.1 & 10.45 & ND & ND \\
\hline $23 \mathrm{H}-4,65-66$ & 213.55 & 78.3 & 9.40 & ND & ND \\
\hline $23 \mathrm{H}-5,65-66$ & 215.05 & 83.4 & 10.01 & ND & ND \\
\hline $23 \mathrm{H}-6,65-66$ & 216.55 & 85.0 & 10.21 & ND & ND \\
\hline $23 \mathrm{H}-7,20-21$ & 217.60 & 81.4 & 9.77 & ND & ND \\
\hline $24 \mathrm{H}-1,65-66$ & 218.55 & 87.5 & 10.50 & ND & ND \\
\hline $24 \mathrm{H}-2,65-66$ & 220.05 & 38.0 & 4.56 & 4.84 & 0.06 \\
\hline $24 \mathrm{H}-3,65-66$ & 221.55 & 81.2 & 9.75 & ND & ND \\
\hline $24 \mathrm{H}-4,65-66$ & 223.05 & 89.1 & 10.70 & ND & ND \\
\hline $24 \mathrm{H}-5,65-66$ & 224.55 & 89.7 & 10.77 & ND & ND \\
\hline $24 \mathrm{H}-6,65-66$ & 226.05 & 88.0 & 10.56 & ND & ND \\
\hline $24 \mathrm{H}-7,40-41$ & 227.30 & 87.3 & 10.48 & ND & ND \\
\hline $25 \mathrm{H}-1,65-66$ & 228.05 & 86.3 & 10.36 & 10.77 & 0.05 \\
\hline $25 \mathrm{H}-2,65-66$ & 229.55 & 87.0 & 10.44 & ND & ND \\
\hline $25 \mathrm{H}-3,65-66$ & 231.05 & 89.3 & 10.72 & ND & ND \\
\hline $25 \mathrm{H}-4,65-66$ & 232.55 & 84.2 & 10.11 & ND & ND \\
\hline $25 \mathrm{H}-5,65-66$ & 234.05 & 87.4 & 10.50 & ND & ND \\
\hline $25 \mathrm{H}-6,65-66$ & 235.55 & 84.4 & 10.13 & ND & ND \\
\hline $25 \mathrm{H}-7,15-16$ & 236.55 & 85.8 & 10.30 & ND & ND \\
\hline $26 \mathrm{H}-1,64-65$ & 237.54 & 85.8 & 10.30 & ND & ND \\
\hline $26 \mathrm{H}-2,64-65$ & 239.04 & 84.6 & 10.15 & ND & ND \\
\hline $26 \mathrm{H}-3,64-65$ & 240.54 & 87.6 & 10.52 & ND & ND \\
\hline $26 \mathrm{H}-4,64-65$ & 242.04 & 87.9 & 10.55 & ND & ND \\
\hline $26 \mathrm{H}-5,64-65$ & 243.54 & 87.9 & 10.55 & ND & ND \\
\hline $26 \mathrm{H}-6,64-65$ & 245.04 & 86.6 & 10.39 & ND & ND \\
\hline $26 \mathrm{H}-7,45-46$ & 246.35 & 87.7 & 10.53 & ND & ND \\
\hline $27 \mathrm{H}-1,65-66$ & 247.05 & 87.7 & 10.52 & 10.79 & 0.05 \\
\hline $27 \mathrm{H}-2,65-66$ & 248.55 & 87.5 & 10.51 & ND & ND \\
\hline $27 \mathrm{H}-3,65-66$ & 250.05 & 90.2 & 10.83 & ND & ND \\
\hline $27 \mathrm{H}-4,65-66$ & 251.55 & 89.4 & 10.73 & ND & ND \\
\hline $27 \mathrm{H}-5,65-66$ & 253.05 & 89.0 & 10.68 & ND & ND \\
\hline $27 \mathrm{H}-6,65-66$ & 254.55 & 87.4 & 10.49 & ND & ND \\
\hline $28 \mathrm{H}-1,64-65$ & 256.54 & 83.6 & 10.03 & ND & ND \\
\hline $28 \mathrm{H}-2,64-65$ & 258.04 & 83.4 & 10.01 & ND & ND \\
\hline $28 \mathrm{H}-3,64-65$ & 259.54 & 85.6 & 10.28 & ND & ND \\
\hline $28 \mathrm{H}-4,64-65$ & 261.04 & 86.6 & 10.39 & ND & ND \\
\hline $28 \mathrm{H}-5,64-65$ & 262.54 & 91.2 & 10.95 & ND & ND \\
\hline $28 \mathrm{H}-6,64-65$ & 264.04 & 89.4 & 10.73 & ND & ND \\
\hline $28 \mathrm{H}-7,40-41$ & 265.30 & 89.6 & 10.75 & ND & ND \\
\hline $29 \mathrm{H}-1,65-66$ & 266.05 & 89.5 & 10.74 & 10.99 & 0.06 \\
\hline $29 \mathrm{H}-2,65-66$ & 267.55 & 88.3 & 10.61 & ND & ND \\
\hline $29 \mathrm{H}-3,65-66$ & 269.05 & 88.0 & 10.56 & ND & ND \\
\hline $29 \mathrm{H}-4,65-66$ & 270.55 & 81.5 & 9.79 & ND & ND \\
\hline $29 \mathrm{H}-5,65-66$ & 272.05 & 86.4 & 10.37 & ND & ND \\
\hline $29 \mathrm{H}-6,65-66$ & 273.55 & 88.4 & 10.61 & ND & ND \\
\hline $29 \mathrm{H}-7,35-36$ & 274.75 & 89.1 & 10.70 & ND & ND \\
\hline $30 \mathrm{H}-1,65-66$ & 275.55 & 91.5 & 10.98 & ND & ND \\
\hline $30 \mathrm{H}-2,65-66$ & 277.05 & 89.4 & 10.73 & ND & ND \\
\hline $30 \mathrm{H}-3,65-66$ & 278.55 & 93.3 & 11.20 & ND & ND \\
\hline $30 \mathrm{H}-4,65-66$ & 280.05 & 86.4 & 10.37 & ND & ND \\
\hline $30 \mathrm{H}-5,65-66$ & 281.55 & 87.8 & 10.55 & ND & ND \\
\hline $30 \mathrm{H}-6,65-66$ & 283.05 & 89.2 & 10.71 & ND & ND \\
\hline
\end{tabular}

\begin{tabular}{|c|c|c|c|c|c|}
\hline \multirow{2}{*}{$\begin{array}{l}\text { Core, section, } \\
\text { interval }(\mathrm{cm})\end{array}$} & \multirow{2}{*}{$\begin{array}{l}\text { Depth CSF } \\
\quad(\mathrm{m})\end{array}$} & \multicolumn{4}{|c|}{ Carbon (wt\%) } \\
\hline & & $\mathrm{CaCO}_{3}$ & IC & $\mathrm{TC}$ & TOC \\
\hline $30 \mathrm{H}-7,39-40$ & 284.29 & 85.1 & 10.22 & ND & ND \\
\hline $31 \mathrm{H}-1,65-66$ & 285.05 & 91.4 & 10.97 & 11.27 & 0.05 \\
\hline $31 \mathrm{H}-2,65-66$ & 286.55 & 90.3 & 10.84 & ND & ND \\
\hline $31 \mathrm{H}-3,60-61$ & 288.00 & 88.8 & 10.66 & ND & ND \\
\hline $31 \mathrm{H}-4,65-66$ & 289.55 & 90.1 & 10.81 & ND & ND \\
\hline $31 \mathrm{H}-5,65-66$ & 291.05 & 88.6 & 10.64 & ND & ND \\
\hline $31 \mathrm{H}-6,65-66$ & 292.55 & 90.6 & 10.88 & ND & ND \\
\hline $31 \mathrm{H}-7,50-51$ & 293.90 & 88.9 & 10.67 & ND & ND \\
\hline $32 \mathrm{H}-1,65-66$ & 294.55 & 89.0 & 10.69 & ND & ND \\
\hline $32 \mathrm{H}-2,65-66$ & 296.05 & 89.8 & 10.78 & ND & ND \\
\hline $32 \mathrm{H}-3,65-66$ & 297.55 & 89.5 & 10.75 & ND & ND \\
\hline $32 \mathrm{H}-4,65-66$ & 299.05 & 89.1 & 10.70 & ND & ND \\
\hline $32 \mathrm{H}-5,95-96$ & 300.85 & 87.7 & 10.53 & ND & ND \\
\hline $32 \mathrm{H}-6,65-66$ & 302.05 & 89.4 & 10.73 & ND & ND \\
\hline $32 \mathrm{H}-7,30-31$ & 303.20 & 90.3 & 10.84 & ND & ND \\
\hline $33 \mathrm{H}-1,65-66$ & 304.05 & 92.2 & 11.07 & 11.35 & 0.05 \\
\hline $33 \mathrm{H}-2,65-66$ & 305.55 & 89.4 & 10.73 & ND & ND \\
\hline $33 \mathrm{H}-3,65-66$ & 307.05 & 88.7 & 10.65 & ND & ND \\
\hline $33 \mathrm{H}-4,65-66$ & 308.55 & 89.1 & 10.69 & ND & ND \\
\hline $33 \mathrm{H}-5,65-66$ & 310.05 & 84.5 & 10.14 & ND & ND \\
\hline $33 \mathrm{H}-6,65-66$ & 311.55 & 90.5 & 10.86 & ND & ND \\
\hline $33 \mathrm{H}-7,49-50$ & 312.89 & 89.6 & 10.76 & ND & ND \\
\hline $34 \mathrm{H}-1,65-66$ & 313.55 & 88.0 & 10.56 & ND & ND \\
\hline $34 \mathrm{H}-2,30-31$ & 314.20 & 90.1 & 10.82 & ND & ND \\
\hline $34 \mathrm{H}-3,65-66$ & 315.15 & 90.2 & 10.83 & ND & ND \\
\hline $34 \mathrm{H}-4,65-66$ & 316.65 & 87.8 & 10.54 & ND & ND \\
\hline $34 \mathrm{H}-5,65-66$ & 318.15 & 88.1 & 10.58 & ND & ND \\
\hline $34 \mathrm{H}-6,65-66$ & 319.65 & 88.0 & 10.57 & ND & ND \\
\hline $34 \mathrm{H}-7,50-51$ & 321.00 & 83.6 & 10.03 & ND & ND \\
\hline $35 \mathrm{H}-1,65-66$ & 323.05 & 88.2 & 10.59 & 10.89 & 0.06 \\
\hline $35 \mathrm{H}-2,65-66$ & 324.55 & 86.8 & 10.42 & ND & ND \\
\hline $35 \mathrm{H}-3,65-66$ & 326.05 & 84.6 & 10.15 & ND & ND \\
\hline $35 \mathrm{H}-4,65-66$ & 327.55 & 90.3 & 10.85 & ND & ND \\
\hline $35 \mathrm{H}-5,65-66$ & 329.05 & 89.3 & 10.72 & ND & ND \\
\hline $35 \mathrm{H}-6,65-66$ & 330.55 & 88.9 & 10.67 & ND & ND \\
\hline $35 \mathrm{H}-7,65-66$ & 332.05 & 89.5 & 10.74 & ND & ND \\
\hline $36 \mathrm{H}-1,65-66$ & 332.55 & 88.9 & 10.67 & ND & ND \\
\hline $36 \mathrm{H}-2,65-66$ & 334.05 & 87.5 & 10.50 & ND & ND \\
\hline $36 \mathrm{H}-3,65-66$ & 335.55 & 89.2 & 10.71 & ND & ND \\
\hline $36 \mathrm{H}-4,65-66$ & 337.05 & 88.8 & 10.66 & ND & ND \\
\hline $36 \mathrm{H}-5,65-66$ & 338.55 & 89.4 & 10.74 & ND & ND \\
\hline $36 \mathrm{H}-6,65-66$ & 340.05 & 83.3 & 9.99 & ND & ND \\
\hline $36 \mathrm{H}-7,34-35$ & 341.24 & 86.0 & 10.32 & ND & ND \\
\hline $37 X-1,60-61$ & 342.00 & 86.8 & 10.42 & 10.76 & 0.06 \\
\hline $37 X-2,63-64$ & 343.53 & 90.1 & 10.82 & ND & ND \\
\hline $37 X-3,63-64$ & 345.03 & 85.3 & 10.24 & ND & ND \\
\hline $37 X-4,36-37$ & 346.26 & 92.3 & 11.08 & ND & ND \\
\hline $37 X-5,64-65$ & 348.04 & 90.0 & 10.80 & ND & ND \\
\hline $37 X-6,23-24$ & 349.13 & 96.4 & 11.57 & ND & ND \\
\hline $37 X-C C, 15-16$ & 349.89 & 90.0 & 10.81 & ND & ND \\
\hline $38 X-1,52-53$ & 351.62 & 89.9 & 10.80 & ND & ND \\
\hline $38 X-2,85-86$ & 353.45 & 90.2 & 10.83 & ND & ND \\
\hline $38 X-3,68-69$ & 354.78 & 87.9 & 10.55 & ND & ND \\
\hline $38 X-4,102-103$ & 356.62 & 90.2 & 10.82 & ND & ND \\
\hline $38 X-5,102-103$ & 358.12 & 89.6 & 10.75 & ND & ND \\
\hline $38 X-6,20-21$ & 358.80 & 90.8 & 10.90 & ND & ND \\
\hline $39 X-1,120-121$ & 361.90 & 89.2 & 10.71 & 10.99 & 0.05 \\
\hline $39 X-2,57-58$ & 362.77 & 89.7 & 10.77 & ND & ND \\
\hline $39 X-3,59-60$ & 364.29 & 89.7 & 10.77 & ND & ND \\
\hline $39 X-4,52-53$ & 365.72 & 89.8 & 10.78 & ND & ND \\
\hline $39 X-5,46-47$ & 367.16 & 87.1 & 10.46 & ND & ND \\
\hline $39 X-6,50-51$ & 368.70 & 88.2 & 10.59 & ND & ND \\
\hline $40 X-1,90-91$ & 371.10 & 87.9 & 10.55 & ND & ND \\
\hline $40 X-2,75-76$ & 372.45 & 88.5 & 10.62 & ND & ND \\
\hline $40 X-3,70-71$ & 373.90 & 88.8 & 10.66 & ND & ND \\
\hline $40 X-4,80-81$ & 375.50 & 85.1 & 10.21 & ND & ND \\
\hline $40 X-5,37-38$ & 376.17 & 81.3 & 9.77 & ND & ND \\
\hline $41 X-1,78-79$ & 380.48 & 87.2 & 10.46 & 10.71 & 0.04 \\
\hline $41 X-2,75-76$ & 381.95 & 87.8 & 10.54 & ND & ND \\
\hline
\end{tabular}


Table T23 (continued).

\begin{tabular}{|c|c|c|c|c|c|}
\hline \multirow{2}{*}{$\begin{array}{l}\text { Core, section, } \\
\text { interval }(\mathrm{cm})\end{array}$} & \multirow{2}{*}{$\begin{array}{l}\text { Depth CSF } \\
\quad(\mathrm{m})\end{array}$} & \multicolumn{4}{|c|}{ Carbon (wt\%) } \\
\hline & & $\mathrm{CaCO}_{3}$ & $\mathrm{IC}$ & $\mathrm{TC}$ & TOC \\
\hline $41 X-3,79-81$ & 383.49 & 89.3 & 10.72 & ND & ND \\
\hline $41 X-4,93-95$ & 385.13 & 86.7 & 10.40 & ND & ND \\
\hline $41 X-5,81-83$ & 386.51 & 80.8 & 9.70 & ND & ND \\
\hline $41 X-6,33-35$ & 387.13 & 85.5 & 10.26 & ND & ND \\
\hline $42 X-1,119-120$ & 390.39 & 83.8 & 10.07 & ND & ND \\
\hline $42 X-2,112-113$ & 391.82 & 82.7 & 9.93 & ND & ND \\
\hline $42 X-3,109-111$ & 393.29 & 90.0 & 10.81 & ND & ND \\
\hline $42 X-4,95-97$ & 394.65 & 88.0 & 10.56 & ND & ND \\
\hline $42 X-5,54-56$ & 395.74 & 88.6 & 10.64 & ND & ND \\
\hline $43 X-1,90-91$ & 399.70 & 90.4 & 10.86 & 11.10 & 0.04 \\
\hline $43 X-2,54-55$ & 400.84 & 89.9 & 10.79 & ND & ND \\
\hline $43 X-3,84-85$ & 402.64 & 89.9 & 10.79 & ND & ND \\
\hline $43 X-4,80-81$ & 404.10 & 87.5 & 10.50 & ND & ND \\
\hline $43 X-5,66-67$ & 405.46 & 83.8 & 10.07 & ND & ND \\
\hline $43 X-6,43-44$ & 406.73 & 82.2 & 9.87 & ND & ND \\
\hline $43 X-7,20-21$ & 407.80 & 86.9 & 10.43 & ND & ND \\
\hline $44 X-1,66-67$ & 409.06 & 88.0 & 10.57 & ND & ND \\
\hline $44 X-2,89-90$ & 410.79 & 78.0 & 9.36 & ND & ND \\
\hline $44 X-3,76-77$ & 412.16 & 84.2 & 10.11 & ND & ND \\
\hline $44 X-4,90-91$ & 413.80 & 81.4 & 9.77 & ND & ND \\
\hline $44 X-5,70-71$ & 415.10 & 88.4 & 10.61 & ND & ND \\
\hline $44 X-6,86-87$ & 416.76 & 88.7 & 10.64 & ND & ND \\
\hline $45 X-1,60-61$ & 418.70 & 90.5 & 10.87 & 11.14 & 0.04 \\
\hline $45 X-2,25-26$ & 419.85 & 74.9 & 8.99 & ND & ND \\
\hline
\end{tabular}

Notes: IC = inorganic carbon, TC $=$ total carbon, $\mathrm{TOC}=$ total organic carbon determined by acidification method. ND $=$ not determined. $\mathrm{BDL}=$ below detection limit $\left(\mathrm{CaCO}_{3}=<1 \mathrm{wt} \%, \mathrm{TOC}=<0.03 \mathrm{wt} \%\right)$ as determined by three times the standard deviation of replicate measures of a low concentration sample. 
Table T24. Moisture and density measurements, Hole U1335A. (Continued on next two pages.)

\begin{tabular}{|c|c|c|c|c|c|c|}
\hline \multirow{2}{*}{$\begin{array}{l}\text { Core, section, } \\
\text { interval }(\mathrm{cm})\end{array}$} & \multirow[b]{2}{*}{$\begin{array}{l}\text { Depth } \\
\operatorname{CSF}(\mathrm{m})\end{array}$} & \multirow{2}{*}{$\begin{array}{l}\text { Water } \\
\text { content } \\
(\%)\end{array}$} & \multicolumn{3}{|c|}{ Density $\left(\mathrm{g} / \mathrm{cm}^{3}\right)$} & \multirow[b]{2}{*}{$\begin{array}{l}\text { Porosity } \\
\text { (\%) }\end{array}$} \\
\hline & & & $\begin{array}{l}\text { Wet } \\
\text { bulk }\end{array}$ & $\begin{array}{l}\text { Dry } \\
\text { bulk }\end{array}$ & Grain & \\
\hline \multicolumn{7}{|l|}{ 320-U1335A- } \\
\hline $1 \mathrm{H}-2,75-76$ & 2.25 & 66.4 & 1.31 & 0.44 & 2.96 & 85.1 \\
\hline $1 \mathrm{H}-3,75-76$ & 3.75 & 61.1 & 1.29 & 0.50 & 2.21 & 77.2 \\
\hline $1 \mathrm{H}-4,75-76$ & 5.25 & 63.9 & 1.35 & 0.49 & 3.05 & 84.0 \\
\hline $1 \mathrm{H}-5,75-76$ & 6.75 & 66.4 & 1.23 & 0.41 & 2.07 & 80.0 \\
\hline $1 \mathrm{H}-6,75-76$ & 7.95 & 61.1 & 1.38 & 0.54 & 3.00 & 82.1 \\
\hline $2 \mathrm{H}-1,75-76$ & 9.65 & 70.4 & 1.26 & 0.37 & 2.75 & 86.5 \\
\hline $2 \mathrm{H}-2,75-76$ & 11.15 & 63.4 & 1.24 & 0.46 & 1.99 & 77.1 \\
\hline $2 \mathrm{H}-3,75-76$ & 12.65 & 56.5 & 1.40 & 0.61 & 2.67 & 77.2 \\
\hline $2 \mathrm{H}-4,75-76$ & 14.15 & 49.3 & 1.51 & 0.76 & 2.78 & 72.5 \\
\hline $2 \mathrm{H}-5,75-76$ & 15.65 & 58.9 & 1.37 & 0.56 & 2.64 & 78.7 \\
\hline $2 \mathrm{H}-6,75-76$ & 17.15 & 61.6 & 1.27 & 0.49 & 2.07 & 76.4 \\
\hline $2 \mathrm{H}-7,40-41$ & 18.30 & 73.5 & 1.25 & 0.33 & 3.11 & 89.4 \\
\hline $3 \mathrm{H}-1,75-76$ & 19.15 & 72.2 & 1.19 & 0.33 & 2.03 & 83.7 \\
\hline $3 \mathrm{H}-2,75-76$ & 20.65 & 68.6 & 1.26 & 0.40 & 2.59 & 84.7 \\
\hline $3 \mathrm{H}-3,75-76$ & 22.15 & 63.9 & 1.34 & 0.48 & 3.00 & 83.8 \\
\hline $3 \mathrm{H}-4,75-76$ & 23.65 & 67.3 & 1.27 & 0.42 & 2.51 & 83.4 \\
\hline $3 \mathrm{H}-5,75-76$ & 25.15 & 65.9 & 1.29 & 0.44 & 2.65 & 83.3 \\
\hline $3 \mathrm{H}-6,75-76$ & 26.65 & 59.2 & 1.33 & 0.54 & 2.38 & 77.1 \\
\hline $3 \mathrm{H}-7,45-46$ & 27.85 & 64.1 & 1.33 & 0.48 & 2.88 & 83.4 \\
\hline $4 \mathrm{H}-1,125-126$ & 29.15 & 65.6 & 1.32 & 0.46 & 2.98 & 84.7 \\
\hline $4 \mathrm{H}-2,75-76$ & 30.15 & 66.9 & 1.29 & 0.43 & 2.69 & 84.1 \\
\hline $4 \mathrm{H}-3,74-75$ & 31.64 & 57.8 & 1.42 & 0.60 & 2.99 & 80.0 \\
\hline $4 \mathrm{H}-4,75-76$ & 33.15 & 48.7 & 1.51 & 0.78 & 2.76 & 71.9 \\
\hline $4 \mathrm{H}-5,75-76$ & 34.65 & 58.5 & 1.40 & 0.58 & 2.92 & 80.1 \\
\hline $4 \mathrm{H}-6,75-76$ & 36.15 & 63.0 & 1.34 & 0.49 & 2.77 & 82.1 \\
\hline $4 \mathrm{H}-7,50-51$ & 37.40 & 59.0 & 1.39 & 0.57 & 2.91 & 80.4 \\
\hline $5 \mathrm{H}-1,75-76$ & 38.15 & 40.5 & 1.68 & 1.00 & 2.98 & 66.4 \\
\hline $5 \mathrm{H}-2,75-76$ & 39.65 & 40.3 & 1.59 & 0.95 & 2.52 & 62.5 \\
\hline $5 \mathrm{H}-3,75-76$ & 41.15 & 55.0 & 1.42 & 0.64 & 2.69 & 76.2 \\
\hline $5 \mathrm{H}-4,75-76$ & 42.65 & 57.7 & 1.41 & 0.60 & 2.89 & 79.4 \\
\hline $5 \mathrm{H}-5,75-76$ & 44.15 & 48.7 & 1.51 & 0.77 & 2.75 & 71.8 \\
\hline $5 \mathrm{H}-6,75-76$ & 45.65 & 59.9 & 1.37 & 0.55 & 2.79 & 80.3 \\
\hline $6 \mathrm{H}-1,75-76$ & 47.65 & 46.6 & 1.54 & 0.82 & 2.76 & 70.2 \\
\hline $6 \mathrm{H}-2,75-76$ & 49.15 & 45.4 & 1.55 & 0.85 & 2.72 & 68.8 \\
\hline $6 \mathrm{H}-3,75-76$ & 50.65 & 41.0 & 1.63 & 0.96 & 2.77 & 65.2 \\
\hline $6 \mathrm{H}-4,75-76$ & 52.15 & 47.8 & 1.55 & 0.81 & 2.94 & 72.5 \\
\hline $6 \mathrm{H}-5,75-76$ & 53.65 & 48.4 & 1.51 & 0.78 & 2.75 & 71.6 \\
\hline $6 \mathrm{H}-6,75-76$ & 55.15 & 60.8 & 1.35 & 0.53 & 2.67 & 80.2 \\
\hline $6 \mathrm{H}-7,30-31$ & 56.20 & 60.1 & 1.37 & 0.55 & 2.74 & 80.1 \\
\hline $7 \mathrm{H}-1,75-76$ & 57.15 & 70.5 & 1.24 & 0.37 & 2.49 & 85.3 \\
\hline $7 \mathrm{H}-2,75-76$ & 58.65 & 74.1 & 1.21 & 0.31 & 2.58 & 87.8 \\
\hline $7 \mathrm{H}-3,75-76$ & 60.15 & 68.9 & 1.28 & 0.40 & 2.87 & 86.1 \\
\hline $7 \mathrm{H}-4,75-76$ & 61.65 & 59.5 & 1.37 & 0.56 & 2.76 & 79.8 \\
\hline $7 \mathrm{H}-5,75-76$ & 63.15 & 68.0 & 1.28 & 0.41 & 2.72 & 85.0 \\
\hline $7 \mathrm{H}-6,75-76$ & 64.65 & 49.0 & 1.54 & 0.78 & 2.99 & 73.7 \\
\hline $7 \mathrm{H}-7,30-31$ & 65.70 & 57.2 & 1.39 & 0.60 & 2.70 & 77.9 \\
\hline $8 \mathrm{H}-1,75-76$ & 66.65 & 52.3 & 1.46 & 0.69 & 2.72 & 74.5 \\
\hline $8 \mathrm{H}-2,75-76$ & 68.15 & 42.8 & 1.64 & 0.94 & 2.98 & 68.5 \\
\hline $8 \mathrm{H}-3,75-76$ & 69.65 & 39.9 & 1.66 & 0.99 & 2.81 & 64.6 \\
\hline $8 \mathrm{H}-4,75-76$ & 71.15 & 42.8 & 1.60 & 0.92 & 2.79 & 67.1 \\
\hline $8 \mathrm{H}-5,75-76$ & 72.65 & 45.4 & 1.59 & 0.87 & 2.97 & 70.7 \\
\hline $8 \mathrm{H}-6,75-76$ & 74.15 & 46.6 & 1.55 & 0.83 & 2.82 & 70.6 \\
\hline $8 \mathrm{H}-7,40-41$ & 75.30 & 45.3 & 1.56 & 0.86 & 2.78 & 69.2 \\
\hline $9 \mathrm{H}-1,75-76$ & 76.15 & 41.7 & 1.64 & 0.96 & 2.90 & 67.0 \\
\hline $9 \mathrm{H}-2,75-76$ & 77.65 & 39.7 & 1.66 & 1.00 & 2.83 & 64.6 \\
\hline $9 \mathrm{H}-3,75-76$ & 79.15 & 42.3 & 1.62 & 0.93 & 2.82 & 66.9 \\
\hline $9 \mathrm{H}-4,75-76$ & 80.65 & 42.4 & 1.64 & 0.95 & 2.97 & 68.0 \\
\hline $9 \mathrm{H}-5,75-76$ & 82.15 & 47.9 & 1.53 & 0.80 & 2.80 & 71.6 \\
\hline $9 \mathrm{H}-6,75-76$ & 83.65 & 39.5 & 1.67 & 1.01 & 2.82 & 64.3 \\
\hline $9 \mathrm{H}-7,75-76$ & 84.65 & 46.2 & 1.58 & 0.85 & 2.95 & 71.3 \\
\hline $10 \mathrm{H}-1,75-76$ & 85.65 & 41.1 & 1.65 & 0.97 & 2.86 & 66.1 \\
\hline $10 \mathrm{H}-2,75-76$ & 87.15 & 38.8 & 1.69 & 1.03 & 2.85 & 63.9 \\
\hline $10 \mathrm{H}-3,75-76$ & 88.65 & 35.6 & 1.77 & 1.14 & 2.96 & 61.5 \\
\hline $10 \mathrm{H}-4,75-76$ & 90.15 & 40.2 & 1.66 & 0.99 & 2.83 & 65.0 \\
\hline $10 \mathrm{H}-5,75-76$ & 91.65 & 40.3 & 1.65 & 0.98 & 2.81 & 64.9 \\
\hline $10 \mathrm{H}-6,75-76$ & 93.15 & 38.6 & 1.72 & 1.05 & 2.98 & 64.7 \\
\hline $10 \mathrm{H}-7,65-66$ & 94.55 & 41.2 & 1.65 & 0.97 & 2.89 & 66.4 \\
\hline
\end{tabular}

\begin{tabular}{|c|c|c|c|c|c|c|}
\hline \multirow[b]{2}{*}{$\begin{array}{l}\text { Core, section, } \\
\text { interval }(\mathrm{cm})\end{array}$} & \multirow[b]{2}{*}{$\begin{array}{c}\text { Depth } \\
\text { CSF }(m)\end{array}$} & \multirow{2}{*}{$\begin{array}{c}\text { Water } \\
\text { content } \\
(\%)\end{array}$} & \multicolumn{3}{|c|}{ Density $\left(\mathrm{g} / \mathrm{cm}^{3}\right)$} & \multirow[b]{2}{*}{$\begin{array}{l}\text { Porosity } \\
\text { (\%) }\end{array}$} \\
\hline & & & $\begin{array}{l}\text { Wet } \\
\text { bulk }\end{array}$ & $\begin{array}{l}\text { Dry } \\
\text { bulk }\end{array}$ & Grain & \\
\hline $11 \mathrm{H}-1,75-76$ & 95.15 & 41.4 & 1.65 & 0.96 & 2.88 & 66.6 \\
\hline $11 \mathrm{H}-2,75-76$ & 96.65 & 48.0 & 1.54 & 0.80 & 2.87 & 72.2 \\
\hline $11 \mathrm{H}-3,75-76$ & 98.15 & 41.5 & 1.63 & 0.96 & 2.83 & 66.3 \\
\hline $11 \mathrm{H}-4,75-76$ & 99.65 & 39.6 & 1.69 & 1.02 & 2.95 & 65.3 \\
\hline $11 \mathrm{H}-5,75-76$ & 101.15 & 40.7 & 1.63 & 0.97 & 2.76 & 64.9 \\
\hline $11 \mathrm{H}-6,75-76$ & 102.65 & 41.1 & 1.64 & 0.96 & 2.82 & 65.8 \\
\hline $11 \mathrm{H}-7,30-31$ & 103.70 & 39.0 & 1.71 & 1.04 & 3.00 & 65.2 \\
\hline $12 \mathrm{H}-1,75-76$ & 104.65 & 40.1 & 1.65 & 0.99 & 2.81 & 64.8 \\
\hline $12 \mathrm{H}-2,75-76$ & 106.15 & 42.0 & 1.62 & 0.94 & 2.82 & 66.6 \\
\hline $12 \mathrm{H}-3,75-76$ & 107.65 & 43.6 & 1.62 & 0.91 & 2.96 & 69.1 \\
\hline $12 \mathrm{H}-4,75-76$ & 109.15 & 44.3 & 1.58 & 0.88 & 2.77 & 68.3 \\
\hline $12 \mathrm{H}-5,75-76$ & 110.65 & 36.8 & 1.71 & 1.08 & 2.79 & 61.3 \\
\hline $12 \mathrm{H}-7,50-51$ & 113.40 & 38.4 & 1.68 & 1.04 & 2.82 & 63.2 \\
\hline $13 \mathrm{H}-1,95-96$ & 114.35 & 41.1 & 1.65 & 0.97 & 2.87 & 66.2 \\
\hline $13 \mathrm{H}-2,75-76$ & 115.65 & 40.9 & 1.68 & 0.99 & 3.00 & 66.9 \\
\hline $13 \mathrm{H}-3,75-76$ & 117.15 & 42.4 & 1.62 & 0.93 & 2.81 & 66.9 \\
\hline $13 \mathrm{H}-4,75-76$ & 118.65 & 38.7 & 1.68 & 1.03 & 2.84 & 63.6 \\
\hline $13 \mathrm{H}-5,75-76$ & 120.15 & 44.1 & 1.62 & 0.90 & 2.98 & 69.7 \\
\hline $13 \mathrm{H}-6,75-76$ & 121.65 & 39.2 & 1.66 & 1.01 & 2.79 & 63.7 \\
\hline $13 \mathrm{H}-7,50-51$ & 122.90 & 37.7 & 1.69 & 1.05 & 2.80 & 62.3 \\
\hline $14 \mathrm{H}-1,75-76$ & 123.65 & 37.9 & 1.74 & 1.08 & 3.04 & 64.4 \\
\hline $14 \mathrm{H}-2,75-76$ & 125.15 & 47.3 & 1.53 & 0.81 & 2.77 & 70.8 \\
\hline $14 \mathrm{H}-3,75-76$ & 126.65 & 44.9 & 1.57 & 0.86 & 2.76 & 68.7 \\
\hline $14 \mathrm{H}-4,75-76$ & 128.15 & 42.0 & 1.65 & 0.96 & 2.95 & 67.6 \\
\hline $14 \mathrm{H}-5,75-76$ & 129.65 & 39.4 & 1.66 & 1.01 & 2.78 & 63.9 \\
\hline $14 \mathrm{H}-6,75-76$ & 131.15 & 37.3 & 1.70 & 1.07 & 2.80 & 61.9 \\
\hline $14 \mathrm{H}-7,60-61$ & 132.50 & 44.0 & 1.62 & 0.90 & 2.95 & 69.3 \\
\hline $15 \mathrm{H}-1,75-76$ & 133.15 & 41.5 & 1.62 & 0.95 & 2.78 & 65.8 \\
\hline $15 \mathrm{H}-2,65-66$ & 134.55 & 43.6 & 1.59 & 0.90 & 2.79 & 67.8 \\
\hline $15 \mathrm{H}-4,75-76$ & 137.15 & 38.1 & 1.69 & 1.05 & 2.81 & 62.8 \\
\hline $15 \mathrm{H}-5,75-76$ & 138.65 & 39.9 & 1.67 & 1.00 & 2.88 & 65.2 \\
\hline $15 \mathrm{H}-6,75-76$ & 140.15 & 43.1 & 1.64 & 0.93 & 2.99 & 68.9 \\
\hline $15 \mathrm{H}-7,40-41$ & 141.30 & 39.0 & 1.67 & 1.02 & 2.79 & 63.5 \\
\hline $16 \mathrm{H}-1,75-76$ & 142.65 & 40.5 & 1.64 & 0.98 & 2.78 & 64.9 \\
\hline $16 \mathrm{H}-2,75-76$ & 144.15 & 49.4 & 1.69 & 1.01 & 2.98 & 66.1 \\
\hline $16 \mathrm{H}-3,75-76$ & 145.65 & 49.4 & 1.50 & 0.76 & 2.77 & 72.5 \\
\hline $16 \mathrm{H}-4,75-76$ & 147.15 & 37.7 & 1.69 & 1.06 & 2.79 & 62.2 \\
\hline $16 \mathrm{H}-5,75-76$ & 148.65 & 37.8 & 1.73 & 1.07 & 2.96 & 63.7 \\
\hline $17 \mathrm{H}-1,75-76$ & 152.15 & 47.4 & 1.52 & 0.80 & 2.70 & 70.3 \\
\hline $17 \mathrm{H}-2,75-76$ & 153.65 & 40.3 & 1.64 & 0.98 & 2.78 & 64.7 \\
\hline $17 \mathrm{H}-3,75-76$ & 155.15 & 40.8 & 1.69 & 1.00 & 3.03 & 67.1 \\
\hline $17 \mathrm{H}-4,75-76$ & 156.65 & 40.7 & 1.64 & 0.97 & 2.78 & 65.1 \\
\hline $17 \mathrm{H}-5,75-76$ & 158.15 & 44.2 & 1.58 & 0.88 & 2.76 & 68.1 \\
\hline $17 \mathrm{H}-6,65-66$ & 159.55 & 52.8 & 1.47 & 0.70 & 2.90 & 76.0 \\
\hline $17 \mathrm{H}-7,40-41$ & 160.80 & 43.4 & 1.63 & 0.92 & 2.97 & 69.0 \\
\hline $18 \mathrm{H}-1,75-76$ & 161.65 & 43.2 & 1.60 & 0.91 & 2.79 & 67.4 \\
\hline $18 \mathrm{H}-2,75-76$ & 163.15 & 42.3 & 1.62 & 0.93 & 2.80 & 66.7 \\
\hline $18 \mathrm{H}-3,75-76$ & 164.65 & 43.7 & 1.62 & 0.91 & 2.96 & 69.2 \\
\hline $18 \mathrm{H}-4,75-76$ & 166.15 & 39.3 & 1.66 & 1.01 & 2.78 & 63.7 \\
\hline $18 \mathrm{H}-5,75-76$ & 167.65 & 39.5 & 1.66 & 1.00 & 2.77 & 63.9 \\
\hline $18 \mathrm{H}-6,75-76$ & 169.15 & 45.7 & 1.58 & 0.86 & 2.92 & 70.6 \\
\hline $19 \mathrm{H}-1,75-76$ & 171.15 & 38.6 & 1.68 & 1.03 & 2.83 & 63.5 \\
\hline $19 \mathrm{H}-2,75-76$ & 172.65 & 44.8 & 1.56 & 0.86 & 2.72 & 68.3 \\
\hline $19 \mathrm{H}-3,75-76$ & 174.15 & 43.6 & 1.58 & 0.89 & 2.72 & 67.3 \\
\hline $19 \mathrm{H}-4,75-76$ & 175.65 & 43.4 & 1.59 & 0.90 & 2.76 & 67.4 \\
\hline $19 \mathrm{H}-5,75-76$ & 177.15 & 47.7 & 1.54 & 0.81 & 2.87 & 71.8 \\
\hline $19 \mathrm{H}-6,75-76$ & 178.65 & 46.0 & 1.54 & 0.83 & 2.69 & 69.2 \\
\hline $19 \mathrm{H}-7,50-51$ & 179.90 & 49.3 & 1.49 & 0.76 & 2.70 & 72.0 \\
\hline $20 \mathrm{H}-1,75-76$ & 180.65 & 41.6 & 1.68 & 0.98 & 3.07 & 68.1 \\
\hline $20 \mathrm{H}-2,75-76$ & 182.15 & 42.1 & 1.61 & 0.93 & 2.73 & 66.0 \\
\hline $20 \mathrm{H}-3,75-76$ & 183.65 & 41.6 & 1.62 & 0.95 & 2.78 & 65.9 \\
\hline $20 \mathrm{H}-4,75-76$ & 185.15 & 40.0 & 1.68 & 1.01 & 2.95 & 65.8 \\
\hline $20 \mathrm{H}-5,75-76$ & 186.65 & 41.9 & 1.60 & 0.93 & 2.72 & 65.7 \\
\hline $20 \mathrm{H}-6,75-76$ & 188.15 & 43.9 & 1.57 & 0.88 & 2.69 & 67.3 \\
\hline $20 \mathrm{H}-7,50-51$ & 189.40 & 42.6 & 1.62 & 0.93 & 2.84 & 67.3 \\
\hline $21 \mathrm{H}-1,75-76$ & 190.15 & 38.0 & 1.68 & 1.04 & 2.78 & 62.4 \\
\hline $21 \mathrm{H}-2,75-76$ & 191.65 & 40.9 & 1.63 & 0.96 & 2.76 & 65.0 \\
\hline $21 \mathrm{H}-3,75-76$ & 193.15 & 40.0 & 1.65 & 0.99 & 2.78 & 64.3 \\
\hline
\end{tabular}


Table T24 (continued). (Continued on next page.)

\begin{tabular}{|c|c|c|c|c|c|c|}
\hline \multirow[b]{2}{*}{$\begin{array}{l}\text { Core, section, } \\
\text { interval }(\mathrm{cm})\end{array}$} & \multirow[b]{2}{*}{$\begin{array}{l}\text { Depth } \\
\operatorname{CSF}(m)\end{array}$} & \multirow{2}{*}{$\begin{array}{l}\text { Water } \\
\text { content } \\
(\%)\end{array}$} & \multicolumn{3}{|c|}{ Density $\left(\mathrm{g} / \mathrm{cm}^{3}\right)$} & \multirow[b]{2}{*}{$\begin{array}{c}\text { Porosity } \\
\text { (\%) }\end{array}$} \\
\hline & & & $\begin{array}{l}\text { Wet } \\
\text { bulk }\end{array}$ & $\begin{array}{l}\text { Dry } \\
\text { bulk }\end{array}$ & Grain & \\
\hline $21 \mathrm{H}-4,75-76$ & 194.65 & 37.5 & 1.74 & 1.09 & 3.00 & 63.7 \\
\hline $21 \mathrm{H}-5,75-76$ & 196.15 & 36.4 & 1.75 & 1.11 & 2.92 & 62.0 \\
\hline $21 \mathrm{H}-6,75-76$ & 197.65 & 40.1 & 1.66 & 0.99 & 2.83 & 64.9 \\
\hline $21 \mathrm{H}-7,30-31$ & 198.60 & 39.4 & 1.66 & 1.01 & 2.79 & 64.0 \\
\hline $22 \mathrm{H}-1,110-111$ & 200.00 & 47.7 & 1.53 & 0.80 & 2.76 & 71.1 \\
\hline $22 \mathrm{H}-2,75-76$ & 201.15 & 39.5 & 1.67 & 1.01 & 2.85 & 64.5 \\
\hline $22 \mathrm{H}-3,75-76$ & 202.65 & 42.3 & 1.64 & 0.95 & 2.94 & 67.8 \\
\hline $22 \mathrm{H}-4,75-76$ & 204.15 & 44.3 & 1.57 & 0.87 & 2.73 & 68.0 \\
\hline $22 \mathrm{H}-5,75-76$ & 205.65 & 36.9 & 1.71 & 1.08 & 2.80 & 61.5 \\
\hline $22 \mathrm{H}-6,75-76$ & 207.15 & 41.2 & 1.65 & 0.97 & 2.91 & 66.5 \\
\hline $22 \mathrm{H}-7,40-41$ & 208.30 & 42.1 & 1.62 & 0.94 & 2.83 & 66.7 \\
\hline $23 \mathrm{H}-2,80-81$ & 210.70 & 39.8 & 1.70 & 1.02 & 2.99 & 65.9 \\
\hline $23 \mathrm{H}-3,75-76$ & 212.15 & 39.0 & 1.69 & 1.03 & 2.87 & 64.2 \\
\hline $23 \mathrm{H}-4,75-76$ & 213.65 & 37.9 & 1.69 & 1.05 & 2.80 & 62.5 \\
\hline $23 \mathrm{H}-5,75-76$ & 215.15 & 35.4 & 1.79 & 1.16 & 3.04 & 61.9 \\
\hline $23 \mathrm{H}-6,75-76$ & 216.65 & 37.4 & 1.71 & 1.07 & 2.85 & 62.5 \\
\hline $23 \mathrm{H}-7,30-31$ & 217.70 & 34.8 & 1.75 & 1.14 & 2.82 & 59.6 \\
\hline $24 \mathrm{H}-1,75-76$ & 218.65 & 35.4 & 1.78 & 1.15 & 2.97 & 61.3 \\
\hline $24 \mathrm{H}-2,75-76$ & 220.15 & 43.3 & 1.60 & 0.91 & 2.82 & 67.7 \\
\hline $24 \mathrm{H}-3,75-76$ & 221.65 & 35.6 & 1.74 & 1.12 & 2.85 & 60.5 \\
\hline $24 \mathrm{H}-4,75-76$ & 223.15 & & 1.81 & 1.21 & 2.95 & 59.0 \\
\hline $24 \mathrm{H}-5,75-76$ & 224.65 & 34.0 & 1.76 & 1.16 & 2.80 & 58.5 \\
\hline $24 \mathrm{H}-6,75-76$ & 226.15 & 35.5 & 1.73 & 1.11 & 2.77 & 59.8 \\
\hline $24 \mathrm{H}-7,50-51$ & 227.40 & 37.6 & 1.73 & 1.08 & 2.97 & 63.6 \\
\hline $25 \mathrm{H}-2,75-76$ & 229.65 & 35.6 & 1.73 & 1.11 & 2.79 & 60.2 \\
\hline $25 \mathrm{H}-3,75-76$ & 231.15 & 37.0 & 1.71 & 1.08 & 2.84 & 61.9 \\
\hline $25 \mathrm{H}-4,75-76$ & 232.65 & 36.2 & 1.71 & 1.09 & 2.75 & 60.4 \\
\hline $25 \mathrm{H}-5,75-76$ & 234.15 & 36.3 & 1.71 & 1.09 & 2.75 & 60.5 \\
\hline $25 \mathrm{H}-6,75-76$ & 235.65 & 42.1 & 1.59 & 0.92 & 2.64 & 65.2 \\
\hline $25 \mathrm{H}-7,25-26$ & 236.65 & & 1.56 & 0.89 & & 65.4 \\
\hline $26 \mathrm{H}-1,75-76$ & 237.65 & 42.0 & 1.57 & 0.91 & 2.56 & 64.4 \\
\hline $26 \mathrm{H}-2,75-76$ & 239.15 & & 1.72 & 1.08 & 2.84 & 61.9 \\
\hline $26 \mathrm{H}-3,75-76$ & 240.65 & 37.2 & 1.69 & 1.06 & 2.76 & 61.5 \\
\hline $26 \mathrm{H}-4,75-76$ & 242.15 & 36.1 & 1.71 & 1.09 & 2.73 & 60.2 \\
\hline $26 \mathrm{H}-5,75-76$ & 243.65 & 34.6 & 1.77 & 1.15 & 2.86 & 59.7 \\
\hline $26 \mathrm{H}-6,75-76$ & 245.15 & 35.8 & 1.72 & 1.10 & 2.75 & 60.0 \\
\hline $26 \mathrm{H}-7,55-56$ & 246.45 & 37.4 & 1.69 & 1.05 & 2.75 & 61.6 \\
\hline $27 \mathrm{H}-1,75-76$ & 247.15 & 37.0 & 1.72 & 1.08 & 2.85 & 62.0 \\
\hline $27 \mathrm{H}-2,75-76$ & 248.65 & 36.3 & 1.71 & 1.09 & 2.75 & 60.5 \\
\hline $27 \mathrm{H}-3,75-76$ & 250.15 & 35.7 & 1.72 & 1.11 & 2.78 & 60.1 \\
\hline $27 \mathrm{H}-4,75-76$ & 251.65 & 36.1 & 1.75 & 1.12 & 2.92 & 61.7 \\
\hline $27 \mathrm{H}-5,75-76$ & 253.15 & 35.4 & 1.73 & 1.12 & 2.79 & 59.9 \\
\hline $27 \mathrm{H}-6,75-76$ & 254.65 & & 1.73 & & 2.80 & 59.9 \\
\hline $28 \mathrm{H}-2,75-76$ & 258.15 & 36.6 & 1.70 & 1.08 & 2.75 & 60.7 \\
\hline $28 \mathrm{H}-3,75-76$ & & & 1.70 & & 2.76 & 61.3 \\
\hline $28 \mathrm{H}-4,75-76$ & 261.15 & 34.6 & 1.78 & 1.17 & 2.94 & 60.3 \\
\hline $28 \mathrm{H}-5,75-76$ & 262.65 & 34.0 & 1.76 & 1.16 & 2.80 & 58.4 \\
\hline $28 \mathrm{H}-6,75-76$ & 264.15 & 32.0 & 1.84 & 1.25 & 2.94 & 57.5 \\
\hline $28 \mathrm{H}-7,50-51$ & 265.40 & 31.2 & 1.79 & 1.23 & 2.72 & 54.6 \\
\hline $29 \mathrm{H}-1,75-76$ & 266.15 & 34.0 & 1.80 & 1.19 & 2.93 & 59.6 \\
\hline $29 \mathrm{H}-2,75-76$ & 267.65 & 36.0 & 1.73 & 1.11 & 2.81 & 60.7 \\
\hline $29 \mathrm{H}-3,75-76$ & 269.15 & 36.1 & 1.72 & 1.10 & 2.78 & 60.6 \\
\hline $29 \mathrm{H}-4,75-76$ & 270.65 & 34.9 & 1.75 & 1.14 & 2.82 & 59.6 \\
\hline $29 \mathrm{H}-5,75-76$ & 272.15 & 33.8 & 1.75 & 1.16 & 2.73 & 57.6 \\
\hline $29 \mathrm{H}-6,75-76$ & 273.65 & 31.7 & 1.84 & 1.26 & 2.93 & 57.1 \\
\hline $29 \mathrm{H}-7,50-51$ & 274.90 & 32.2 & 1.89 & 1.28 & 3.16 & 59.4 \\
\hline $30 \mathrm{H}-1,75-76$ & 275.65 & 32.6 & 1.80 & 1.21 & 2.84 & 57.2 \\
\hline $30 \mathrm{H}-2,75-76$ & 277.15 & 33.8 & 1.78 & 1.18 & 2.84 & 58.6 \\
\hline $30 \mathrm{H}-3,75-76$ & 278.65 & 34.7 & 1.76 & 1.15 & 2.84 & 59.5 \\
\hline $30 \mathrm{H}-4,75-76$ & 280.15 & 33.8 & 1.77 & 1.17 & 2.80 & 58.3 \\
\hline $30 \mathrm{H}-5,75-76$ & 281.65 & 34.2 & 1.75 & 1.15 & 2.76 & 58.4 \\
\hline $31 \mathrm{H}-2,75-76$ & 286.65 & 30.5 & 1.78 & 1.24 & 2.62 & 52.8 \\
\hline $31 \mathrm{H}-3,75-76$ & 288.15 & 32.7 & 1.78 & 1.19 & 2.76 & 56.7 \\
\hline $31 \mathrm{H}-4,75-76$ & 289.65 & 31.7 & 1.81 & 1.23 & 2.81 & 56.0 \\
\hline $31 \mathrm{H}-6,75-76$ & 292.65 & 32.3 & 1.80 & 1.22 & 2.83 & 56.9 \\
\hline $31 \mathrm{H}-7,50-51$ & 293.90 & 32.5 & 1.81 & 1.22 & 2.87 & 57.4 \\
\hline $32 \mathrm{H}-4,75-76$ & 299.15 & 32.6 & 1.78 & 1.20 & 2.75 & 56.5 \\
\hline $32 \mathrm{H}-5,104-105$ & 300.94 & 34.8 & 1.74 & 1.13 & 2.77 & 59.1 \\
\hline
\end{tabular}

\begin{tabular}{|c|c|c|c|c|c|c|}
\hline \multirow[b]{2}{*}{$\begin{array}{l}\text { Core, section, } \\
\text { interval }(\mathrm{cm})\end{array}$} & \multirow[b]{2}{*}{$\begin{array}{c}\text { Depth } \\
\operatorname{CSF}(m)\end{array}$} & \multirow{2}{*}{$\begin{array}{l}\text { Water } \\
\text { content } \\
(\%)\end{array}$} & \multicolumn{3}{|c|}{ Density $\left(\mathrm{g} / \mathrm{cm}^{3}\right)$} & \multirow[b]{2}{*}{$\begin{array}{c}\text { Porosity } \\
\text { (\%) }\end{array}$} \\
\hline & & & $\begin{array}{l}\text { Wet } \\
\text { bulk }\end{array}$ & $\begin{array}{l}\text { Dry } \\
\text { bulk }\end{array}$ & Grain & \\
\hline $32 \mathrm{H}-6,75-76$ & 302.15 & 31.8 & 1.81 & 1.24 & 2.83 & 56.3 \\
\hline $33 \mathrm{H}-1,75-76$ & 304.15 & 32.2 & 1.82 & 1.23 & 2.87 & 57.1 \\
\hline $33 \mathrm{H}-2,75-76$ & 305.65 & 36.1 & 1.72 & 1.10 & 2.80 & 60.7 \\
\hline $33 \mathrm{H}-3,75-76$ & 307.15 & 34.1 & 1.77 & 1.17 & 2.85 & 59.0 \\
\hline $33 \mathrm{H}-4,75-76$ & 308.65 & 32.0 & 1.80 & 1.23 & 2.81 & 56.3 \\
\hline $33 \mathrm{H}-5,75-76$ & 310.15 & 34.7 & 1.74 & 1.13 & 2.75 & 58.8 \\
\hline $33 \mathrm{H}-6,75-76$ & 311.65 & 30.3 & 1.71 & 1.19 & 2.40 & 50.4 \\
\hline $34 \mathrm{H}-1,75-76$ & 313.65 & 31.2 & 1.81 & 1.25 & 2.80 & 55.3 \\
\hline $34 \mathrm{H}-2,40-41$ & 314.30 & 34.5 & 1.74 & 1.14 & 2.77 & 58.8 \\
\hline $34 \mathrm{H}-3,75-76$ & 315.25 & 32.0 & 1.81 & 1.23 & 2.82 & 56.4 \\
\hline $34 \mathrm{H}-4,75-76$ & 316.75 & 31.9 & 1.66 & 1.13 & 2.35 & 51.8 \\
\hline $34 \mathrm{H}-5,75-76$ & 318.25 & 33.6 & 1.86 & 1.23 & 3.15 & 60.9 \\
\hline $34 \mathrm{H}-6,75-76$ & 319.75 & 32.3 & 1.84 & 1.24 & 2.96 & 58.0 \\
\hline $34 \mathrm{H}-7,60-61$ & 321.10 & 32.1 & 1.79 & 1.21 & 2.77 & 56.2 \\
\hline $35 \mathrm{H}-1,75-76$ & 323.15 & 32.1 & 1.79 & 1.21 & 2.77 & 56.2 \\
\hline $35 \mathrm{H}-2,75-76$ & 324.65 & 30.8 & 1.82 & 1.26 & 2.78 & 54.8 \\
\hline $35 \mathrm{H}-3,75-76$ & 326.15 & 30.7 & 1.81 & 1.26 & 2.76 & 54.4 \\
\hline $35 \mathrm{H}-4,75-76$ & 327.65 & 29.4 & 1.83 & 1.29 & 2.71 & 52.4 \\
\hline $35 \mathrm{H}-5,75-76$ & 329.15 & 30.2 & 1.84 & 1.29 & 2.80 & 54.2 \\
\hline $35 \mathrm{H}-6,75-76$ & 330.65 & 37.1 & 1.69 & 1.06 & 2.74 & 61.2 \\
\hline $35 \mathrm{H}-7,75-76$ & 332.15 & 30.4 & 1.83 & 1.27 & 2.78 & 54.3 \\
\hline $36 \mathrm{H}-1,75-76$ & 332.65 & 32.7 & 1.78 & 1.20 & 2.78 & 56.9 \\
\hline $36 \mathrm{H}-2,75-76$ & 334.15 & 32.4 & 1.77 & 1.20 & 2.73 & 56.1 \\
\hline $36 \mathrm{H}-3,75-76$ & 335.65 & 30.7 & 1.81 & 1.25 & 2.74 & 54.2 \\
\hline $36 \mathrm{H}-4,75-76$ & 337.15 & & & & & 55.5 \\
\hline $36 \mathrm{H}-5,75-76$ & 338.65 & 31.0 & 1.80 & 1.24 & 2.73 & 54.4 \\
\hline $36 \mathrm{H}-6,75-76$ & 340.15 & & & & & 56.7 \\
\hline $36 \mathrm{H}-7,45-46$ & 341.35 & 32.4 & 1.78 & 1.20 & 2.75 & 56.3 \\
\hline $37 X-1,52-53$ & 341.92 & 32.8 & 1.77 & 1.19 & 2.74 & 56.6 \\
\hline $37 X-2,71-72$ & 343.61 & 33.7 & 1.76 & 1.17 & 2.79 & 58.1 \\
\hline $37 X-3,82-83$ & 345.22 & 33.5 & 1.77 & 1.18 & 2.80 & 57.9 \\
\hline $37 X-4,36-37$ & 346.26 & 32.7 & 1.80 & 1.21 & 2.84 & 57.4 \\
\hline $37 X-5,81-82$ & 348.21 & 32.1 & 1.80 & 1.22 & 2.81 & 56.5 \\
\hline $37 X-6,18-19$ & 349.08 & 33.5 & 1.78 & 1.19 & 2.84 & 58.2 \\
\hline $38 X-1,61-62$ & 351.71 & 35.9 & 1.71 & 1.10 & 2.75 & 60.1 \\
\hline $38 X-2,97-98$ & 353.57 & 58.2 & 1.39 & 0.58 & 2.77 & 79.1 \\
\hline $38 X-4,112-113$ & 356.72 & 31.3 & 1.82 & 1.25 & 2.82 & 55.6 \\
\hline $38 \times-5,115-116$ & & & & & & \\
\hline $38 X-6,26-27$ & 358.86 & 32.9 & 1.78 & 1.19 & 2.79 & 57.2 \\
\hline $39 X-1,129-130$ & & & & 1.16 & 2.76 & 58.2 \\
\hline $39 X-2,68-69$ & 362.88 & 34.2 & 1.77 & 1.16 & 2.84 & 59.1 \\
\hline $39 x-3,69-70$ & 364.39 & 31.3 & 1.84 & 1.26 & 2.88 & 56.2 \\
\hline 39X-4, 70-71 & 365.90 & 34.5 & 1.75 & 1.14 & 2.79 & 59.0 \\
\hline $39 X-5,58-59$ & 367.28 & 29.7 & 1.84 & 1.29 & 2.78 & 53.4 \\
\hline $40 X-1,83-84$ & 371.03 & 34.9 & 1.77 & 1.15 & 2.88 & 60.1 \\
\hline $40 X-2,84-85$ & 372.54 & 33.9 & 1.75 & 1.16 & 2.77 & 58.1 \\
\hline $40 X-3,88-89$ & 374.08 & 33.8 & 1.77 & 1.18 & 2.83 & 58.5 \\
\hline $40 x-4,64-65$ & 375.34 & 34.9 & 1.74 & 1.14 & 2.80 & 59.5 \\
\hline $40 X-5,39-40$ & & & & & & \\
\hline $41 X-2,68-69$ & 381.88 & 30.5 & 1.88 & 1.31 & 2.96 & 55.8 \\
\hline $41 X-3,97-98$ & & & 1.91 & & 3.20 & 59.3 \\
\hline $41 X-4,97-98$ & 385.17 & 29.2 & 1.93 & 1.37 & 3.03 & 55.0 \\
\hline $41 X-5,36-37$ & 386.06 & 29.7 & 1.93 & 1.35 & 3.07 & 55.9 \\
\hline $41 X-6,23-24$ & 387.03 & 29.8 & 1.97 & 1.38 & 3.24 & 57.3 \\
\hline $42 X-1,108-109$ & 390.28 & 30.1 & 1.90 & 1.33 & 3.02 & 55.9 \\
\hline $42 X-2,76-77$ & 391.46 & 30.8 & 1.84 & 1.27 & 2.85 & 55.3 \\
\hline $42 X-3,60-61$ & 392.80 & 28.9 & 1.87 & 1.33 & 2.82 & 52.8 \\
\hline $42 X-4,74-75$ & 394.44 & 29.9 & 1.86 & 1.30 & 2.85 & 54.2 \\
\hline $42 X-5,30-31$ & 395.50 & 29.1 & 1.91 & 1.36 & 2.97 & 54.4 \\
\hline $43 X-1,75-76$ & 399.55 & 29.2 & 1.88 & 1.33 & 2.87 & 53.6 \\
\hline $43 X-2,44-45$ & 400.74 & 27.4 & 1.91 & 1.39 & 2.85 & 51.3 \\
\hline $43 X-3,74-75$ & 402.54 & 27.3 & 1.97 & 1.44 & 3.03 & 52.6 \\
\hline $43 X-4,92-93$ & 404.22 & 27.6 & 1.88 & 1.36 & 2.76 & 50.7 \\
\hline $43 \times-5,77-78$ & 405.57 & 29.6 & 1.93 & 1.36 & 3.07 & 55.7 \\
\hline $43 X-6,56-57$ & 406.86 & 30.1 & 1.85 & 1.29 & 2.83 & 54.3 \\
\hline $43 X-7,32-33$ & 407.92 & 29.1 & 1.84 & 1.31 & 2.75 & 52.4 \\
\hline $44 X-1,66-67$ & 409.06 & 28.2 & 1.89 & 1.36 & 2.85 & 52.3 \\
\hline $44 X-2,89-90$ & 410.79 & 30.4 & 1.90 & 1.32 & 3.05 & 56.6 \\
\hline
\end{tabular}


Table T24 (continued).

\begin{tabular}{|c|c|c|c|c|c|c|}
\hline \multirow[b]{2}{*}{$\begin{array}{l}\text { Core, section, } \\
\text { interval }(\mathrm{cm})\end{array}$} & \multirow[b]{2}{*}{$\begin{array}{l}\text { Depth } \\
\operatorname{CSF}(\mathrm{m})\end{array}$} & \multirow{2}{*}{$\begin{array}{c}\text { Water } \\
\text { content } \\
(\%)\end{array}$} & \multicolumn{3}{|c|}{ Density $\left(\mathrm{g} / \mathrm{cm}^{3}\right)$} & \multirow[b]{2}{*}{$\begin{array}{c}\text { Porosity } \\
\text { (\%) }\end{array}$} \\
\hline & & & $\begin{array}{l}\text { Wet } \\
\text { bulk }\end{array}$ & $\begin{array}{l}\text { Dry } \\
\text { bulk }\end{array}$ & Grain & \\
\hline $44 X-3,75-76$ & 412.15 & 25.2 & 1.94 & 1.45 & 2.77 & 47.6 \\
\hline $44 X-4,90-91$ & 413.80 & 26.3 & 2.02 & 1.49 & 3.08 & 51.7 \\
\hline $44 X-5,70-71$ & 415.10 & 26.5 & 2.03 & 1.49 & 3.13 & 52.4 \\
\hline $44 X-6,88-89$ & 416.78 & 25.6 & 1.95 & 1.45 & 2.83 & 48.8 \\
\hline
\end{tabular}


Table T25. Split-core $P$-wave velocity measurements, Hole U1335A. (Continued on next two pages.)

\begin{tabular}{|c|c|c|c|c|c|c|c|c|c|}
\hline \multirow{2}{*}{$\begin{array}{l}\text { Core, } \\
\text { section }\end{array}$} & \multirow{2}{*}{$\begin{array}{c}\text { Depth } \\
\text { CSF }(m)\end{array}$} & \multicolumn{3}{|c|}{ Velocity $(\mathrm{m} / \mathrm{s})$} & \multirow{2}{*}{$\begin{array}{c}\text { Core, } \\
\text { section }\end{array}$} & \multirow{2}{*}{$\begin{array}{l}\text { Depth } \\
\text { CSF }(m)\end{array}$} & \multicolumn{3}{|c|}{ Velocity $(\mathrm{m} / \mathrm{s})$} \\
\hline & & $x$-axis & $y$-axis & $z$-axis & & & $x$-axis & $y$-axis & $z$-axis \\
\hline \multicolumn{5}{|c|}{ 320-U1335A- } & $7 \mathrm{H}-1$ & 57.84 & 1519 & & \\
\hline $1 \mathrm{H}-2$ & 2.83 & & & 1495 & $7 \mathrm{H}-2$ & 59.34 & 1527 & & \\
\hline $1 \mathrm{H}-2$ & 2.90 & 1519 & & & $7 \mathrm{H}-3$ & 60.70 & & 1534 & 1510 \\
\hline $1 \mathrm{H}-3$ & 4.37 & & & 1496 & $7 \mathrm{H}-3$ & 60.79 & 1521 & & \\
\hline $1 \mathrm{H}-3$ & 4.46 & 1520 & & & $7 \mathrm{H}-4$ & 62.26 & & & 1500 \\
\hline $1 \mathrm{H}-4$ & 5.72 & 1527 & & & $7 \mathrm{H}-4$ & 62.34 & 1495 & & \\
\hline $1 \mathrm{H}-4$ & 5.87 & & 1498 & 1499 & $7 \mathrm{H}-5$ & 63.85 & 1515 & & \\
\hline $1 \mathrm{H}-6$ & 8.49 & 1530 & & & $7 \mathrm{H}-6$ & 65.25 & & 1514 & 1502 \\
\hline $1 \mathrm{H}-6$ & 8.58 & & & 1500 & $7 \mathrm{H}-6$ & 65.34 & 1508 & & \\
\hline $2 \mathrm{H}-1$ & 10.23 & 1516 & & & $8 \mathrm{H}-1$ & 67.35 & 1506 & & \\
\hline $2 \mathrm{H}-1$ & 10.32 & & 1508 & 1498 & $8 \mathrm{H}-2$ & 68.78 & & 1511 & 1506 \\
\hline $2 \mathrm{H}-2$ & 11.71 & & & 1501 & $8 \mathrm{H}-3$ & 70.18 & & 1512 & 1509 \\
\hline $2 \mathrm{H}-2$ & 11.80 & 1520 & & & $8 \mathrm{H}-3$ & 70.24 & 1523 & & \\
\hline $2 \mathrm{H}-3$ & 13.25 & & 1509 & 1502 & $8 \mathrm{H}-4$ & 71.75 & & 1515 & 1494 \\
\hline $2 \mathrm{H}-3$ & 13.35 & 1518 & & & $8 \mathrm{H}-4$ & 71.84 & 1513 & & \\
\hline $2 \mathrm{H}-4$ & 14.75 & & 1520 & 1503 & $8 \mathrm{H}-5$ & 73.25 & & 1403 & 1504 \\
\hline $2 \mathrm{H}-4$ & 14.86 & 1523 & & & $8 \mathrm{H}-5$ & 73.34 & 1496 & & \\
\hline $2 \mathrm{H}-5$ & 16.19 & & 1512 & 1503 & $8 \mathrm{H}-6$ & 74.77 & & 1509 & 1508 \\
\hline $2 \mathrm{H}-5$ & 16.30 & 1515 & & & $8 \mathrm{H}-6$ & 74.84 & 1519 & & \\
\hline $2 \mathrm{H}-6$ & 17.75 & & & 1506 & $9 \mathrm{H}-1$ & 76.76 & & 1522 & 1517 \\
\hline $3 \mathrm{H}-1$ & 19.77 & & 1519 & 1504 & $9 \mathrm{H}-1$ & 76.85 & 1523 & & \\
\hline $3 \mathrm{H}-1$ & 19.86 & 1542 & & & $9 \mathrm{H}-2$ & 78.25 & & 1510 & \\
\hline $3 \mathrm{H}-2$ & 21.22 & & 1512 & 1498 & $9 \mathrm{H}-2$ & 78.35 & 3007 & & \\
\hline $3 \mathrm{H}-2$ & 21.30 & 1525 & & & $9 \mathrm{H}-3$ & 79.65 & & 2366 & 1502 \\
\hline $3 \mathrm{H}-3$ & 22.74 & & 1404 & 1499 & $9 \mathrm{H}-3$ & 79.73 & 1540 & & \\
\hline $3 \mathrm{H}-3$ & 22.85 & 1510 & & & $9 \mathrm{H}-4$ & 81.23 & 1533 & & \\
\hline $3 \mathrm{H}-4$ & 24.26 & & 1512 & 1493 & $9 \mathrm{H}-4$ & 81.31 & & & 1503 \\
\hline $3 \mathrm{H}-4$ & 24.35 & 1522 & & & $9 \mathrm{H}-5$ & 82.73 & 1520 & & \\
\hline $3 \mathrm{H}-5$ & 25.74 & & 1508 & 1496 & $9 \mathrm{H}-5$ & 82.81 & & 1517 & 1504 \\
\hline $3 \mathrm{H}-5$ & 25.81 & 1517 & & & $9 \mathrm{H}-6$ & 84.24 & 1541 & & \\
\hline $3 \mathrm{H}-6$ & 27.29 & & 1498 & 1490 & $9 \mathrm{H}-6$ & 84.32 & & 1511 & 1503 \\
\hline $3 \mathrm{H}-6$ & 27.36 & 1536 & & & $10 \mathrm{H}-1$ & 86.24 & 1568 & & \\
\hline $4 \mathrm{H}-1$ & 29.26 & & 1506 & 1493 & $10 \mathrm{H}-1$ & 86.33 & & 1531 & 1527 \\
\hline $4 \mathrm{H}-1$ & 29.35 & 1515 & & & $10 \mathrm{H}-2$ & 87.73 & 1565 & & \\
\hline $4 \mathrm{H}-2$ & 30.56 & & 1414 & 1495 & $10 \mathrm{H}-2$ & 87.81 & & 1541 & 1533 \\
\hline $4 \mathrm{H}-2$ & 30.81 & 1556 & & & $10 \mathrm{H}-3$ & 89.15 & 1556 & & \\
\hline $4 \mathrm{H}-3$ & 32.27 & & 1397 & 1498 & $10 \mathrm{H}-3$ & 89.22 & & 1525 & 1525 \\
\hline $4 \mathrm{H}-3$ & 32.34 & 1521 & & & $10 \mathrm{H}-4$ & 90.71 & 1548 & & \\
\hline $4 \mathrm{H}-4$ & 33.62 & & 2638 & 1501 & $10 \mathrm{H}-4$ & 90.79 & & 1511 & 1509 \\
\hline $4 \mathrm{H}-4$ & 33.86 & 1507 & & & $10 \mathrm{H}-5$ & 92.22 & 1555 & & \\
\hline $4 \mathrm{H}-5$ & 35.20 & & 1498 & 1501 & $10 \mathrm{H}-5$ & 92.31 & & 1523 & 1527 \\
\hline $4 \mathrm{H}-5$ & 35.29 & 1473 & & & $10 \mathrm{H}-6$ & 93.71 & 1535 & & \\
\hline $4 \mathrm{H}-6$ & 36.74 & & 1509 & 1452 & $10 \mathrm{H}-6$ & 93.80 & & 2696 & 1774 \\
\hline $4 \mathrm{H}-6$ & 36.85 & 1481 & & & $11 \mathrm{H}-1$ & 95.73 & 1529 & & \\
\hline $5 \mathrm{H}-1$ & 38.79 & & 1504 & 1454 & $11 \mathrm{H}-1$ & 95.81 & & 1508 & 1506 \\
\hline $5 \mathrm{H}-1$ & 38.86 & 1490 & & & $11 \mathrm{H}-2$ & 97.11 & 1519 & & \\
\hline $5 \mathrm{H}-2$ & 40.23 & & 1503 & 1503 & $11 \mathrm{H}-2$ & 97.20 & & & 1504 \\
\hline $5 \mathrm{H}-2$ & 40.30 & 1473 & & & $11 \mathrm{H}-3$ & 98.75 & 1524 & & \\
\hline $5 \mathrm{H}-3$ & 41.77 & & & 1500 & $11 \mathrm{H}-4$ & 100.25 & 1520 & & \\
\hline $5 \mathrm{H}-3$ & 41.85 & 1478 & & & $11 \mathrm{H}-4$ & 100.32 & & 1515 & 1507 \\
\hline $5 \mathrm{H}-4$ & 43.25 & & 1512 & 1506 & $11 \mathrm{H}-5$ & 101.74 & 1535 & & \\
\hline $5 \mathrm{H}-4$ & 43.33 & 1517 & & & $11 \mathrm{H}-5$ & 101.81 & & 1514 & 1508 \\
\hline $5 \mathrm{H}-5$ & 44.77 & & & 1505 & $11 \mathrm{H}-6$ & 103.21 & 1547 & & \\
\hline $5 \mathrm{H}-5$ & 44.85 & 1528 & & & $11 \mathrm{H}-6$ & 103.29 & & 1507 & 1503 \\
\hline $5 \mathrm{H}-6$ & 46.21 & & 1498 & 1504 & $12 \mathrm{H}-1$ & 105.24 & 1547 & & \\
\hline $5 \mathrm{H}-6$ & 46.28 & 1491 & & & $12 \mathrm{H}-1$ & 105.31 & & 1513 & 1508 \\
\hline $6 \mathrm{H}-1$ & 48.27 & & 1514 & 1503 & $12 \mathrm{H}-2$ & 106.73 & 1537 & & \\
\hline $6 \mathrm{H}-1$ & 48.34 & 1517 & & & $12 \mathrm{H}-2$ & 106.81 & & 1506 & 1498 \\
\hline $6 \mathrm{H}-2$ & 49.71 & & 1508 & 1506 & $12 \mathrm{H}-3$ & 108.11 & 1536 & & \\
\hline $6 \mathrm{H}-2$ & 49.80 & 1492 & & & $12 \mathrm{H}-3$ & 108.19 & & & 1505 \\
\hline $6 \mathrm{H}-3$ & 51.25 & & 1508 & 1503 & $12 \mathrm{H}-4$ & 109.79 & & 1512 & 1506 \\
\hline $6 \mathrm{H}-3$ & 51.34 & 1502 & & & $12 \mathrm{H}-5$ & 111.31 & & 1520 & 1519 \\
\hline $6 \mathrm{H}-4$ & 52.75 & & 1504 & 1472 & $12 \mathrm{H}-7$ & 113.51 & 1557 & & \\
\hline $6 \mathrm{H}-4$ & 52.85 & 1464 & & & $13 \mathrm{H}-3$ & 117.64 & 1534 & & \\
\hline $6 \mathrm{H}-5$ & 54.21 & & 1400 & 1515 & $13 \mathrm{H}-4$ & 119.30 & & 1388 & \\
\hline $6 \mathrm{H}-5$ & 54.29 & 1533 & & & $13 \mathrm{H}-4$ & 119.37 & 1500 & & \\
\hline $6 \mathrm{H}-6$ & 55.72 & & 1419 & 1496 & $13 \mathrm{H}-5$ & 120.80 & & 1408 & \\
\hline $6 \mathrm{H}-6$ & 55.85 & 1509 & & & $13 \mathrm{H}-5$ & 120.86 & 2770 & & \\
\hline
\end{tabular}


Table T25 (continued). (Continued on next page.)

\begin{tabular}{|c|c|c|c|c|c|c|c|c|c|}
\hline \multirow{2}{*}{$\begin{array}{l}\text { Core, } \\
\text { section }\end{array}$} & \multirow{2}{*}{$\begin{array}{c}\text { Depth } \\
\text { CSF }(m)\end{array}$} & \multicolumn{3}{|c|}{ Velocity $(\mathrm{m} / \mathrm{s})$} & \multirow{2}{*}{$\begin{array}{l}\text { Core, } \\
\text { section }\end{array}$} & \multirow{2}{*}{$\begin{array}{c}\text { Depth } \\
\text { CSF }(\mathrm{m})\end{array}$} & \multicolumn{3}{|c|}{ Velocity $(\mathrm{m} / \mathrm{s})$} \\
\hline & & $x$-axis & $y$-axis & $z$-axis & & & $x$-axis & $y$-axis & $z$-axis \\
\hline $13 \mathrm{H}-6$ & 122.35 & 1521 & & & $22 \mathrm{H}-3$ & 203.25 & 1534 & & \\
\hline $14 \mathrm{H}-1$ & 124.22 & 1525 & & & $22 \mathrm{H}-4$ & 204.76 & & 1447 & 1513 \\
\hline $14 \mathrm{H}-1$ & 124.30 & & 1526 & 1522 & $22 \mathrm{H}-4$ & 204.84 & 1500 & & \\
\hline $14 \mathrm{H}-2$ & 125.87 & 1518 & & & $22 \mathrm{H}-5$ & 206.37 & 1503 & & \\
\hline $14 \mathrm{H}-3$ & 127.14 & 1534 & & & $22 \mathrm{H}-6$ & 207.78 & & 1544 & 1466 \\
\hline $14 \mathrm{H}-3$ & 127.22 & & 1521 & & $22 \mathrm{H}-6$ & 207.85 & 1497 & & \\
\hline $14 \mathrm{H}-4$ & 128.72 & 1505 & & & $23 \mathrm{H}-4$ & 214.22 & 1511 & & \\
\hline $14 \mathrm{H}-5$ & 130.24 & 1539 & & & $23 \mathrm{H}-4$ & 214.29 & & 1552 & \\
\hline $14 \mathrm{H}-5$ & 130.32 & & 1528 & 1529 & $23 \mathrm{H}-5$ & 215.72 & 1536 & & \\
\hline $14 \mathrm{H}-6$ & 131.73 & 1525 & & & $23 \mathrm{H}-6$ & 217.22 & 1543 & & \\
\hline $14 \mathrm{H}-6$ & 131.81 & & 1529 & 1518 & $23 \mathrm{H}-6$ & 217.29 & & 1443 & 1470 \\
\hline $15 \mathrm{H}-1$ & 133.84 & 1464 & & & $24 \mathrm{H}-1$ & 219.27 & & 1550 & \\
\hline $15 \mathrm{H}-3$ & 136.18 & & 1523 & 1522 & $24 \mathrm{H}-1$ & 219.35 & 1526 & & \\
\hline $15 \mathrm{H}-3$ & 136.26 & 1517 & & & $24 \mathrm{H}-2$ & 220.78 & & 1558 & 1478 \\
\hline $15 \mathrm{H}-4$ & 137.75 & & 1531 & 1517 & $24 \mathrm{H}-2$ & 220.86 & 1511 & & \\
\hline $15 \mathrm{H}-4$ & 137.84 & 1490 & & & $24 \mathrm{H}-3$ & 222.17 & & 1563 & 1534 \\
\hline $15 \mathrm{H}-5$ & 139.35 & 1509 & & & $24 \mathrm{H}-3$ & 222.25 & 1531 & & \\
\hline $15 \mathrm{H}-6$ & 140.74 & & 1406 & & $24 \mathrm{H}-4$ & 223.78 & & 1563 & 1562 \\
\hline $15 \mathrm{H}-6$ & 140.84 & 1505 & & & $24 \mathrm{H}-4$ & 223.86 & 1567 & & \\
\hline $16 \mathrm{H}-1$ & 143.35 & 1506 & & & $24 \mathrm{H}-5$ & 225.15 & 1541 & & \\
\hline $16 \mathrm{H}-2$ & 144.76 & & 1515 & 1515 & $24 \mathrm{H}-5$ & 225.23 & & 1538 & 1532 \\
\hline $16 \mathrm{H}-2$ & 144.85 & 1530 & & & $24 \mathrm{H}-6$ & 226.71 & 1540 & & \\
\hline $16 \mathrm{H}-3$ & 146.25 & 1501 & & & $24 \mathrm{H}-6$ & 226.79 & & 1561 & 1531 \\
\hline $17 \mathrm{H}-1$ & 152.85 & 1514 & & & $25 \mathrm{H}-2$ & 230.30 & & 1543 & 1523 \\
\hline $17 \mathrm{H}-2$ & 154.34 & 1515 & & & $25 \mathrm{H}-2$ & 230.37 & 1542 & & \\
\hline $17 \mathrm{H}-3$ & 155.75 & 1510 & & & $25 \mathrm{H}-3$ & 231.57 & 1554 & & \\
\hline $17 \mathrm{H}-4$ & 157.25 & & & 1518 & $25 \mathrm{H}-3$ & 231.65 & & & 1540 \\
\hline $17 \mathrm{H}-4$ & 157.35 & 1493 & & & $25 \mathrm{H}-4$ & 233.27 & & 1412 & \\
\hline $17 \mathrm{H}-5$ & 158.84 & 1511 & & & $25 \mathrm{H}-5$ & 234.77 & & 1539 & 1535 \\
\hline $17 \mathrm{H}-6$ & 160.25 & & & 1518 & $25 \mathrm{H}-5$ & 234.84 & 1561 & & \\
\hline $17 \mathrm{H}-6$ & 160.35 & 1499 & & & $25 \mathrm{H}-6$ & 236.28 & & & 1532 \\
\hline $18 \mathrm{H}-1$ & 162.37 & 1521 & & & $26 \mathrm{H}-1$ & 238.35 & 1506 & & \\
\hline $18 \mathrm{H}-2$ & 163.86 & 1483 & & & $26 \mathrm{H}-2$ & 239.77 & & 1414 & \\
\hline $18 \mathrm{H}-3$ & 165.18 & & 1421 & 1523 & $26 \mathrm{H}-2$ & 239.85 & 1543 & & \\
\hline $18 \mathrm{H}-3$ & 165.26 & 1521 & & & $26 \mathrm{H}-3$ & 241.17 & & & 1524 \\
\hline $18 \mathrm{H}-4$ & 166.78 & & & 1469 & $26 \mathrm{H}-3$ & 241.24 & 2785 & & \\
\hline $18 \mathrm{H}-4$ & 166.85 & 1500 & & & $26 \mathrm{H}-4$ & 242.78 & & & 1469 \\
\hline $18 \mathrm{H}-5$ & 168.27 & & 1412 & 1520 & $26 \mathrm{H}-4$ & 242.86 & 1534 & & \\
\hline $18 \mathrm{H}-5$ & 168.36 & 1505 & & & $26 \mathrm{H}-5$ & 244.26 & & 1557 & 1532 \\
\hline $19 \mathrm{H}-1$ & 171.86 & 1471 & & & $26 \mathrm{H}-5$ & 244.34 & 1537 & & \\
\hline $19 \mathrm{H}-2$ & 173.28 & & & 1513 & $26 \mathrm{H}-6$ & 245.78 & & 1542 & 1468 \\
\hline $19 \mathrm{H}-2$ & 173.34 & 1493 & & & $26 \mathrm{H}-6$ & 245.85 & 1538 & & \\
\hline $19 \mathrm{H}-3$ & 174.68 & & & 1786 & $27 \mathrm{H}-1$ & 247.65 & 1549 & & \\
\hline $19 \mathrm{H}-3$ & 174.75 & 1495 & & & $27 \mathrm{H}-2$ & 249.27 & & 1558 & 1533 \\
\hline $19 \mathrm{H}-4$ & 176.26 & & & 1514 & $27 \mathrm{H}-2$ & 249.35 & 1496 & & \\
\hline $19 \mathrm{H}-4$ & 176.35 & 1467 & & & $27 \mathrm{H}-3$ & 250.67 & & 1554 & \\
\hline $19 \mathrm{H}-5$ & 177.76 & & & 1362 & $27 \mathrm{H}-3$ & 250.75 & 1560 & & \\
\hline $19 \mathrm{H}-5$ & 177.85 & 1480 & & & $27 \mathrm{H}-5$ & 253.75 & & 1569 & 1539 \\
\hline $19 \mathrm{H}-6$ & 179.36 & 1482 & & & $27 \mathrm{H}-5$ & 253.84 & 1537 & & \\
\hline $20 \mathrm{H}-1$ & 181.35 & 1468 & & & $27 \mathrm{H}-6$ & 255.26 & & 1561 & 1531 \\
\hline $20 \mathrm{H}-2$ & 182.75 & & 1529 & 1517 & $27 \mathrm{H}-6$ & 255.35 & 1535 & & \\
\hline $20 \mathrm{H}-2$ & 182.86 & 1508 & & & $28 \mathrm{H}-2$ & 258.85 & 1513 & & \\
\hline $20 \mathrm{H}-3$ & 184.25 & 1494 & & & $28 \mathrm{H}-3$ & 260.15 & & 1542 & \\
\hline $20 \mathrm{H}-4$ & 185.78 & & 1429 & & $28 \mathrm{H}-3$ & 260.24 & 1529 & & \\
\hline $20 \mathrm{H}-4$ & 185.85 & 1524 & & & $28 \mathrm{H}-4$ & 261.75 & & 1585 & 1549 \\
\hline $20 \mathrm{H}-5$ & 187.23 & & & 1464 & $28 \mathrm{H}-4$ & 261.86 & 1525 & & \\
\hline $20 \mathrm{H}-5$ & 187.35 & 1512 & & & $28 \mathrm{H}-5$ & 263.28 & & 1573 & 1532 \\
\hline $20 \mathrm{H}-6$ & 188.85 & 1506 & & & $28 \mathrm{H}-5$ & 263.35 & 1515 & & \\
\hline $21 \mathrm{H}-1$ & 190.76 & & 1421 & & $28 \mathrm{H}-6$ & 264.76 & & 1557 & 1557 \\
\hline $21 \mathrm{H}-1$ & 190.84 & 1548 & & & $28 \mathrm{H}-6$ & 264.85 & 1539 & & \\
\hline $21 \mathrm{H}-2$ & 192.36 & 1471 & & & $29 \mathrm{H}-1$ & 266.77 & & & 1549 \\
\hline $21 \mathrm{H}-3$ & 193.74 & 1494 & & & $29 \mathrm{H}-1$ & 266.85 & 1532 & & \\
\hline $21 \mathrm{H}-4$ & 195.27 & & 1429 & & $29 \mathrm{H}-2$ & 268.27 & & & 1477 \\
\hline $21 \mathrm{H}-4$ & 195.35 & 1494 & & & $29 \mathrm{H}-2$ & 268.35 & 1518 & & \\
\hline $21 \mathrm{H}-5$ & 196.81 & & 1428 & 1470 & $29 \mathrm{H}-3$ & 269.66 & & & 1534 \\
\hline $21 \mathrm{H}-6$ & 198.17 & & 1442 & 1462 & $29 \mathrm{H}-3$ & 269.74 & 1515 & & \\
\hline $21 \mathrm{H}-6$ & 198.25 & 1503 & & & $29 \mathrm{H}-4$ & 271.26 & & 1574 & 1542 \\
\hline $22 \mathrm{H}-2$ & 201.73 & 1494 & & & $29 \mathrm{H}-4$ & 271.35 & 3023 & & \\
\hline $22 \mathrm{H}-3$ & 203.17 & & & 1516 & $29 \mathrm{H}-4$ & 271.35 & 1529 & & \\
\hline
\end{tabular}


Table T25 (continued).

\begin{tabular}{|c|c|c|c|c|}
\hline \multirow{2}{*}{$\begin{array}{c}\text { Core, } \\
\text { section }\end{array}$} & \multirow{2}{*}{$\begin{array}{c}\text { Depth } \\
\text { CSF }(m)\end{array}$} & \multicolumn{3}{|c|}{ Velocity $(\mathrm{m} / \mathrm{s})$} \\
\hline & & $x$-axis & $y$-axis & $z$-axis \\
\hline $29 \mathrm{H}-5$ & 272.72 & & 1475 & 1539 \\
\hline $29 \mathrm{H}-5$ & 272.85 & 1540 & & \\
\hline $29 \mathrm{H}-6$ & 274.24 & & 1558 & 1559 \\
\hline $30 \mathrm{H}-1$ & 276.30 & & 1558 & 1558 \\
\hline $30 \mathrm{H}-1$ & 276.36 & 1549 & & \\
\hline $30 \mathrm{H}-2$ & 277.72 & & 1552 & 1547 \\
\hline $30 \mathrm{H}-2$ & 277.81 & 1565 & & \\
\hline $30 \mathrm{H}-3$ & 279.14 & & 1558 & \\
\hline $30 \mathrm{H}-3$ & 279.24 & 1561 & & \\
\hline $30 \mathrm{H}-4$ & 280.79 & & & 1560 \\
\hline $30 \mathrm{H}-4$ & 280.86 & 1543 & & \\
\hline $30 \mathrm{H}-5$ & 282.25 & & & 1558 \\
\hline $30 \mathrm{H}-5$ & 282.35 & 1545 & & \\
\hline $30 \mathrm{H}-6$ & 283.76 & & 1474 & \\
\hline $30 \mathrm{H}-6$ & 283.85 & 1515 & & \\
\hline $31 \mathrm{H}-1$ & 285.85 & 1503 & & \\
\hline $31 \mathrm{H}-2$ & 287.27 & & 1566 & 1558 \\
\hline $31 \mathrm{H}-2$ & 287.35 & 1525 & & \\
\hline $31 \mathrm{H}-3$ & 288.66 & & & 1563 \\
\hline $31 \mathrm{H}-3$ & 288.74 & 1536 & & \\
\hline $31 \mathrm{H}-4$ & 290.24 & & 1467 & 1557 \\
\hline $31 \mathrm{H}-4$ & 290.34 & 1535 & & \\
\hline $31 \mathrm{H}-5$ & 291.75 & & & 1554 \\
\hline $31 \mathrm{H}-5$ & 291.85 & 1538 & & \\
\hline $31 \mathrm{H}-6$ & 293.27 & & 1564 & 1548 \\
\hline $31 \mathrm{H}-6$ & 293.35 & 1543 & & \\
\hline $32 \mathrm{H}-1$ & 295.24 & & & 1551 \\
\hline $32 \mathrm{H}-1$ & 295.35 & 1552 & & \\
\hline $32 \mathrm{H}-2$ & 296.74 & & 1571 & 1559 \\
\hline $32 \mathrm{H}-2$ & 296.84 & 1575 & & \\
\hline $32 \mathrm{H}-3$ & 298.15 & & 1566 & \\
\hline $32 \mathrm{H}-3$ & 298.25 & 1570 & & \\
\hline $32 \mathrm{H}-4$ & 299.75 & & 1581 & \\
\hline $32 \mathrm{H}-4$ & 299.85 & 1618 & & \\
\hline $32 \mathrm{H}-5$ & 301.23 & & 1551 & 1545 \\
\hline $32 \mathrm{H}-5$ & 301.34 & 1557 & & \\
\hline $32 \mathrm{H}-6$ & 302.78 & & & 1525 \\
\hline $32 \mathrm{H}-6$ & 302.85 & 1568 & & \\
\hline $33 \mathrm{H}-1$ & 304.72 & & 1437 & \\
\hline $33 \mathrm{H}-1$ & 304.84 & 1565 & & \\
\hline $33 \mathrm{H}-2$ & 306.25 & & 2495 & 1571 \\
\hline $33 \mathrm{H}-2$ & 306.35 & 1547 & & \\
\hline $33 \mathrm{H}-3$ & 307.66 & & & 1491 \\
\hline $33 \mathrm{H}-3$ & 307.74 & 1553 & & \\
\hline $33 \mathrm{H}-4$ & 309.26 & & 1557 & 1546 \\
\hline $33 \mathrm{H}-4$ & 309.35 & 1555 & & \\
\hline $33 \mathrm{H}-5$ & 310.74 & & 1578 & 1577 \\
\hline $33 \mathrm{H}-5$ & 310.84 & 1557 & & \\
\hline $33 \mathrm{H}-6$ & 312.28 & & 1579 & 1563 \\
\hline $33 \mathrm{H}-6$ & 312.36 & 1549 & & \\
\hline $34 \mathrm{H}-3$ & 315.89 & & 1551 & 1547 \\
\hline $34 \mathrm{H}-3$ & 315.95 & 1539 & & \\
\hline $34 \mathrm{H}-4$ & 317.26 & & 1561 & 1553 \\
\hline
\end{tabular}

\begin{tabular}{|c|c|c|c|c|}
\hline \multirow{2}{*}{$\begin{array}{l}\text { Core, } \\
\text { section }\end{array}$} & \multirow{2}{*}{$\begin{array}{l}\text { Depth } \\
\operatorname{CSF}(\mathrm{m})\end{array}$} & \multicolumn{3}{|c|}{ Velocity $(\mathrm{m} / \mathrm{s})$} \\
\hline & & $x$-axis & $y$-axis & $z$-axis \\
\hline $34 \mathrm{H}-4$ & 317.32 & 3123 & & \\
\hline $34 \mathrm{H}-4$ & 317.32 & 1541 & & \\
\hline $34 \mathrm{H}-5$ & 318.88 & & 1474 & \\
\hline $34 \mathrm{H}-5$ & 318.95 & 1528 & & \\
\hline $34 \mathrm{H}-6$ & 320.39 & & 1589 & 1546 \\
\hline $34 \mathrm{H}-6$ & 320.47 & 1538 & & \\
\hline $35 \mathrm{H}-1$ & 323.70 & 1546 & & \\
\hline $35 \mathrm{H}-1$ & 323.79 & & 1434 & 1557 \\
\hline $35 \mathrm{H}-2$ & 325.26 & & 1570 & 1556 \\
\hline $35 \mathrm{H}-2$ & 325.35 & 1572 & & \\
\hline $35 \mathrm{H}-3$ & 326.76 & & 1584 & 1563 \\
\hline $35 \mathrm{H}-3$ & 326.85 & 1575 & & \\
\hline $35 \mathrm{H}-4$ & 328.27 & & 1576 & 1562 \\
\hline $35 \mathrm{H}-4$ & 328.35 & 1580 & & \\
\hline $35 \mathrm{H}-5$ & 329.85 & 1609 & & \\
\hline $35 \mathrm{H}-6$ & 331.14 & 1572 & & \\
\hline $35 \mathrm{H}-6$ & 331.22 & & 1594 & 1553 \\
\hline $36 \mathrm{H}-3$ & 336.28 & & 1560 & 1556 \\
\hline $36 \mathrm{H}-3$ & 336.36 & 1577 & & \\
\hline $36 \mathrm{H}-4$ & 337.80 & & 1574 & 1559 \\
\hline $36 \mathrm{H}-5$ & 339.35 & 1540 & & \\
\hline $36 \mathrm{H}-6$ & 340.76 & & 1555 & 1554 \\
\hline $36 \mathrm{H}-6$ & 340.85 & 1534 & & \\
\hline $38 \mathrm{X}-1$ & 352.52 & 1575 & & \\
\hline $38 X-2$ & 353.99 & 1570 & & \\
\hline $38 \mathrm{X}-3$ & 355.39 & 1558 & & \\
\hline $38 \mathrm{X}-4$ & 356.78 & 1620 & & \\
\hline $38 X-5$ & 358.54 & 1583 & & \\
\hline $40 X-1$ & 370.93 & 1571 & & \\
\hline $40 X-2$ & 372.81 & 1593 & & \\
\hline $40 X-3$ & 374.11 & 1590 & & \\
\hline $40 X-4$ & 374.91 & 1639 & & \\
\hline $41 X-1$ & 381.03 & 1578 & & \\
\hline $41 X-2$ & 382.53 & 1566 & & \\
\hline $41 X-3$ & 383.89 & 1631 & & \\
\hline $41 X-4$ & 385.62 & 1650 & & \\
\hline $41 X-5$ & 386.35 & 1618 & & \\
\hline $42 X-1$ & 390.17 & 1577 & & \\
\hline $42 X-2$ & 391.90 & 1602 & & \\
\hline $42 X-3$ & 393.50 & 1640 & & \\
\hline $42 X-4$ & 394.84 & 1701 & & \\
\hline $43 X-1$ & 400.21 & 1613 & & \\
\hline $43 X-2$ & 401.69 & 1816 & & \\
\hline $43 X-3$ & 403.13 & 1664 & & \\
\hline $43 X-4$ & 404.68 & 1775 & & \\
\hline $43 X-5$ & 406.27 & 1759 & & \\
\hline $43 X-6$ & 407.24 & 1735 & & \\
\hline $44 X-1$ & 409.82 & 1771 & & \\
\hline $44 X-2$ & 411.35 & 1801 & & \\
\hline $44 X-3$ & 412.53 & 4832 & & \\
\hline $44 X-5$ & 415.51 & 4235 & & \\
\hline $44 X-6$ & 417.00 & 1761 & & \\
\hline $45 X-1$ & 419.20 & 1674 & & \\
\hline
\end{tabular}


Table T26. Thermal conductivity, Hole U1335A.

\begin{tabular}{|c|c|c|}
\hline $\begin{array}{l}\text { Core, section, } \\
\text { interval }(\mathrm{cm})\end{array}$ & $\begin{array}{l}\text { Depth } \\
\text { CSF (m) }\end{array}$ & $\begin{array}{c}\text { Thermal } \\
\text { conductivity } \\
(\mathrm{W} /[\mathrm{m} \cdot \mathrm{K}])\end{array}$ \\
\hline \multicolumn{3}{|l|}{ 320-U1335A- } \\
\hline $1 \mathrm{H}-3,115$ & 4.15 & 0.926 \\
\hline $2 \mathrm{H}-3,115$ & 13.05 & 0.985 \\
\hline $3 \mathrm{H}-3,115$ & 22.55 & 0.797 \\
\hline $4 \mathrm{H}-3,115$ & 32.05 & 0.889 \\
\hline $5 \mathrm{H}-3,115$ & 41.55 & 0.922 \\
\hline $6 \mathrm{H}-3,115$ & 51.05 & 1.092 \\
\hline $7 \mathrm{H}-3,115$ & 60.55 & 0.757 \\
\hline $8 \mathrm{H}-3,115$ & 70.05 & 1.176 \\
\hline $9 \mathrm{H}-3,115$ & 79.55 & 1.078 \\
\hline $10 \mathrm{H}-3,115$ & 89.05 & 1.188 \\
\hline $11 \mathrm{H}-3,115$ & 98.55 & 1.049 \\
\hline $12 \mathrm{H}-3,115$ & 108.05 & 1.129 \\
\hline $13 \mathrm{H}-3,115$ & 117.55 & 1.099 \\
\hline $14 \mathrm{H}-3,115$ & 127.05 & 1.150 \\
\hline $15 \mathrm{H}-3,115$ & 136.05 & 1.165 \\
\hline $16 \mathrm{H}-3,115$ & 146.05 & 1.107 \\
\hline $17 \mathrm{H}-3,115$ & 155.55 & 1.048 \\
\hline $18 \mathrm{H}-3,115$ & 165.05 & 1.139 \\
\hline $19 \mathrm{H}-3,115$ & 174.55 & 1.069 \\
\hline $20 \mathrm{H}-3,115$ & 184.05 & 1.099 \\
\hline $21 \mathrm{H}-3,115$ & 193.55 & 1.086 \\
\hline $22 \mathrm{H}-3,115$ & 203.05 & 1.230 \\
\hline $23 \mathrm{H}-3,115$ & 212.55 & 1.164 \\
\hline $24 \mathrm{H}-3,115$ & 222.05 & 1.212 \\
\hline $25 \mathrm{H}-3,115$ & 231.55 & 1.213 \\
\hline $26 \mathrm{H}-3,115$ & 241.05 & 1.174 \\
\hline $27 \mathrm{H}-3,115$ & 250.55 & 1.273 \\
\hline $28 \mathrm{H}-3,115$ & 260.05 & 1.220 \\
\hline $29 \mathrm{H}-3,115$ & 269.55 & 1.221 \\
\hline $30 \mathrm{H}-3,115$ & 279.05 & 1.334 \\
\hline $31 \mathrm{H}-3,115$ & 288.55 & 1.319 \\
\hline $32 \mathrm{H}-3,115$ & 298.05 & 1.296 \\
\hline $33 \mathrm{H}-3,115$ & 307.55 & 1.250 \\
\hline $34 \mathrm{H}-3,115$ & 315.65 & 1.297 \\
\hline $35 \mathrm{H}-3,115$ & 326.55 & 1.322 \\
\hline $36 \mathrm{H}-3,115$ & 336.05 & 1.331 \\
\hline $37 X-3,115$ & 345.55 & 1.224 \\
\hline $38 X-3,115$ & 355.25 & 1.270 \\
\hline $39 X-3,115$ & 364.85 & 1.280 \\
\hline $40 X-3,115$ & 374.35 & 1.226 \\
\hline $41 X-3,115$ & 383.85 & 1.086 \\
\hline $42 X-3,115$ & 393.35 & 1.090 \\
\hline
\end{tabular}


Table T27. Shipboard core top, composite, and corrected composite depths, Site U1335.

\begin{tabular}{crrrr}
\hline & & & & \\
Core & Depth & Offset & \multicolumn{2}{c}{ Top depth $(\mathrm{m})$} \\
\cline { 4 - 5 } & CSF $)$ & $(\mathrm{m})$ & CCSF-A & CCSF-B \\
\hline 320-U1335A- & & & & \\
$1 \mathrm{H}$ & 0.00 & 0.14 & 0.14 & 0.12 \\
$2 \mathrm{H}$ & 8.90 & 1.01 & 9.91 & 8.56 \\
$3 \mathrm{H}$ & 18.40 & 1.31 & 19.71 & 17.03 \\
$4 \mathrm{H}$ & 27.90 & 3.04 & 30.94 & 26.73 \\
$5 \mathrm{H}$ & 37.40 & 5.17 & 42.57 & 36.78 \\
$6 \mathrm{H}$ & 46.90 & 5.99 & 52.89 & 45.70 \\
$7 \mathrm{H}$ & 56.40 & 7.09 & 63.49 & 54.85 \\
$8 \mathrm{H}$ & 65.90 & 9.19 & 75.09 & 64.88 \\
$9 \mathrm{H}$ & 75.40 & 10.09 & 85.49 & 73.86 \\
$10 \mathrm{H}$ & 84.90 & 11.05 & 95.95 & 82.90 \\
$11 \mathrm{H}$ & 94.40 & 12.86 & 107.26 & 92.67 \\
$12 \mathrm{H}$ & 103.90 & 14.09 & 117.99 & 101.94 \\
$13 \mathrm{H}$ & 113.40 & 13.24 & 126.64 & 109.42 \\
$14 \mathrm{H}$ & 122.90 & 15.30 & 138.20 & 119.40 \\
$15 \mathrm{H}$ & 132.40 & 16.35 & 148.75 & 128.52 \\
$16 \mathrm{H}$ & 141.90 & 16.35 & 158.25 & 136.73 \\
$17 \mathrm{H}$ & 151.40 & 20.00 & 171.40 & 148.09 \\
$18 \mathrm{H}$ & 160.90 & 20.47 & 181.37 & 156.70 \\
$19 \mathrm{H}$ & 170.40 & 21.31 & 191.71 & 165.63 \\
$20 \mathrm{H}$ & 179.90 & 22.73 & 202.63 & 175.07 \\
$21 \mathrm{H}$ & 189.40 & 24.12 & 213.52 & 184.48 \\
$22 \mathrm{H}$ & 198.90 & 25.98 & 224.88 & 194.30 \\
$23 \mathrm{H}$ & 208.40 & 28.42 & 236.82 & 204.61 \\
$24 \mathrm{H}$ & 217.90 & 31.63 & 249.53 & 215.60 \\
$25 \mathrm{H}$ & 227.40 & 32.77 & 260.17 & 224.79 \\
$26 \mathrm{H}$ & 236.90 & 34.64 & 271.54 & 234.61 \\
$27 \mathrm{H}$ & 246.40 & 36.94 & 283.34 & 244.80 \\
$28 \mathrm{H}$ & 255.90 & 37.78 & 293.68 & 253.74 \\
$29 \mathrm{H}$ & 265.40 & 39.49 & 304.89 & 263.43 \\
$30 \mathrm{H}$ & 274.90 & 40.56 & 315.46 & 272.56 \\
$31 \mathrm{H}$ & 284.40 & 42.63 & 327.03 & 282.56 \\
$32 \mathrm{H}$ & 293.90 & 43.96 & 337.86 & 291.91 \\
$33 \mathrm{H}$ & 303.40 & 45.74 & 349.14 & 301.66 \\
$34 \mathrm{H}$ & 312.90 & 48.42 & 361.32 & 312.18 \\
$35 \mathrm{H}$ & 322.40 & 50.83 & 373.23 & 322.47 \\
$36 \mathrm{H}$ & 331.90 & 52.00 & 383.90 & 331.69 \\
$37 \mathrm{X}$ & 341.40 & 52.00 & 393.40 & 339.90 \\
$43 \mathrm{X}$ & 398.80 & 52.00 & 450.80 & 389.49 \\
$35 \mathrm{X}$ & 418.10 & 52.00 & 460.40 & 397.79 \\
$39 \mathrm{X}$ & 351.10 & 52.00 & 403.10 & 348.28 \\
$40 \mathrm{X}$ & 360.70 & 52.00 & 412.70 & 356.57 \\
$41 \mathrm{X}$ & 370.20 & 52.00 & 422.20 & 364.78 \\
& 389.70 & 52.00 & 431.70 & 372.99 \\
& & & 470.10 & 406.17
\end{tabular}

\begin{tabular}{crrrr}
\hline & & & & \\
Core & Cepth & Cffset & Top depth $(\mathrm{m})$ \\
\cline { 4 - 5 } & & $(\mathrm{m})$ & CCSF-A & CCSF-B \\
\hline $320-\mathrm{U} 1335 \mathrm{~B}-$ & & & & \\
$1 \mathrm{H}$ & 0.00 & 0.00 & 0.00 & 0.00 \\
$2 \mathrm{H}$ & 3.30 & -0.18 & 3.12 & 2.70 \\
$3 \mathrm{H}$ & 12.80 & 1.17 & 13.97 & 12.07 \\
$4 \mathrm{H}$ & 22.30 & 2.57 & 24.87 & 21.49 \\
$5 \mathrm{H}$ & 31.80 & 4.23 & 36.03 & 31.13 \\
$6 \mathrm{H}$ & 41.30 & 5.60 & 46.90 & 40.52 \\
$7 \mathrm{H}$ & 50.80 & 6.77 & 57.57 & 49.74 \\
$8 \mathrm{H}$ & 60.30 & 8.61 & 68.91 & 59.54 \\
$9 \mathrm{H}$ & 69.80 & 9.65 & 79.45 & 68.65 \\
$10 \mathrm{H}$ & 79.30 & 11.90 & 91.20 & 78.80 \\
$11 \mathrm{H}$ & 88.80 & 13.11 & 101.91 & 88.05 \\
$12 \mathrm{H}$ & 98.30 & 14.50 & 112.80 & 97.46 \\
$13 \mathrm{H}$ & 107.80 & 15.40 & 123.20 & 106.44 \\
$14 \mathrm{H}$ & 117.30 & 16.74 & 134.04 & 115.81 \\
$15 \mathrm{H}$ & 126.80 & 17.36 & 144.16 & 124.56 \\
$16 \mathrm{H}$ & 136.30 & 19.28 & 155.58 & 134.42 \\
$17 \mathrm{H}$ & 145.80 & 19.28 & 165.08 & 142.63 \\
$18 \mathrm{H}$ & 155.30 & 20.30 & 175.60 & 151.72 \\
$19 \mathrm{H}$ & 164.80 & 22.31 & 187.11 & 161.67 \\
$20 \mathrm{H}$ & 174.30 & 24.03 & 198.33 & 171.36 \\
$21 \mathrm{H}$ & 183.80 & 25.05 & 208.85 & 180.45 \\
$22 \mathrm{H}$ & 193.30 & 25.97 & 219.27 & 189.45 \\
$23 \mathrm{H}$ & 202.80 & 28.92 & 231.72 & 200.21 \\
$24 \mathrm{H}$ & 212.30 & 31.09 & 243.39 & 210.29 \\
$25 \mathrm{H}$ & 221.80 & 32.54 & 254.34 & 219.75 \\
$26 \mathrm{H}$ & 231.30 & 34.22 & 265.52 & 229.41 \\
$27 \mathrm{H}$ & 240.80 & 36.01 & 276.81 & 239.17 \\
$28 \mathrm{H}$ & 250.30 & 37.38 & 287.68 & 248.56 \\
$29 \mathrm{H}$ & 259.80 & 39.36 & 299.16 & 258.47 \\
$30 \mathrm{H}$ & 269.30 & 41.95 & 311.25 & 268.92 \\
$31 \mathrm{H}$ & 278.80 & 43.33 & 322.13 & 278.33 \\
$32 \mathrm{H}$ & 288.30 & 45.06 & 333.36 & 288.02 \\
$33 \mathrm{H}$ & 297.80 & 46.44 & 344.24 & 297.43 \\
$34 \mathrm{H}$ & 307.30 & 47.82 & 355.12 & 306.82 \\
$35 \mathrm{H}$ & 316.80 & 49.88 & 366.68 & 316.81 \\
$36 \mathrm{H}$ & 326.30 & 51.85 & 378.15 & 326.72 \\
$37 \mathrm{H}$ & 335.80 & 54.25 & 390.05 & 337.01 \\
$38 \mathrm{H}$ & 343.80 & 54.25 & 398.05 & 343.92 \\
$39 \mathrm{H}$ & 352.80 & 54.25 & 407.05 & 351.69 \\
$40 \mathrm{H}$ & 362.30 & 54.25 & 416.55 & 359.90 \\
$41 \mathrm{H}$ & 370.10 & 54.25 & 424.35 & 366.64 \\
$42 \mathrm{X}$ & 378.20 & 54.25 & 432.45 & 373.64 \\
$43 \mathrm{X}$ & 386.20 & 54.25 & 440.45 & 380.55 \\
$44 \mathrm{X}$ & 395.80 & 54.25 & 450.05 & 388.85 \\
& 405.40 & 54.25 & 459.65 & 397.14 \\
& 415.00 & 54.25 & 469.25 & 405.43 \\
\hline & & & &
\end{tabular}


Table T28. Splice tie points, Site U1335. (Continued on next page.)

\begin{tabular}{|c|c|c|c|c|c|c|}
\hline \multirow{2}{*}{$\begin{array}{l}\text { Hole, core, section, } \\
\text { interval }(\mathrm{cm})\end{array}$} & \multicolumn{2}{|c|}{ Depth $(m)$} & & \multirow{2}{*}{$\begin{array}{l}\text { Hole, core, section, } \\
\text { interval }(\mathrm{cm})\end{array}$} & \multicolumn{2}{|c|}{ Depth $(\mathrm{m})$} \\
\hline & CSF & CCSF-A & & & CSF & CCSF-A \\
\hline $320-$ & & & & $320-$ & & \\
\hline U1335B-1H-2, 30 & 1.80 & 1.80 & Tie to & U1335A-1H-2, 16 & 1.66 & 1.80 \\
\hline U1335A-1H-6, 55 & 7.75 & 7.89 & Tie to & U1335B-2H-4, 26 & 8.06 & 7.89 \\
\hline U1335B-2H-6, 19 & 10.99 & 10.82 & Tie to & U1335A-2H-1, 91 & 9.81 & 10.82 \\
\hline U1335A-2H-6, 53 & 16.93 & 17.93 & Tie to & U1335B-3H-3, 97 & 16.77 & 17.93 \\
\hline U1335B-3H-6, 23 & 20.53 & 21.70 & Tie to & U1335A-3H-2, 49 & 20.39 & 21.70 \\
\hline U1335A-3H-6, 132 & 27.22 & 28.52 & Tie to & U1335B-4H-3, 65 & 25.95 & 28.52 \\
\hline U1335B-4H-5, 144 & 29.74 & 32.31 & Tie to & U1335A-4H-1, 137 & 29.27 & 32.31 \\
\hline U1335A-4H-5, 68 & 34.58 & 37.62 & Tie to & U1335B-5H-2, 9 & 33.39 & 37.62 \\
\hline U1335B-5H-6, 117 & 40.47 & 44.71 & Tie to & U1335A-5H-2, 63 & 39.53 & 44.71 \\
\hline U1335A-5H-5, 56 & 43.96 & 49.13 & Tie to & U1335B-6H-2, 73 & 43.53 & 49.13 \\
\hline U1335B-6H-6, 8 & 48.88 & 54.48 & Tie to & U1335A-6H-2, 9 & 48.49 & 54.48 \\
\hline U1335A-6H-5, 82 & 53.72 & 59.71 & Tie to & U1335B-7H-2, 64 & 52.94 & 59.71 \\
\hline U1335B-7H-5, 89 & 57.69 & 64.46 & Tie to & U1335A-7H-1, 98 & 57.38 & 64.46 \\
\hline U1335A-7H-6, 74 & 64.64 & 71.73 & Tie to & U1335B-8H-2, 132 & 63.12 & 71.73 \\
\hline U1335B-8H-6, 49 & 68.29 & 76.90 & Tie to & U1335A-8H-2, 31 & 67.71 & 76.90 \\
\hline U1335A-8H-5, 9 & 71.99 & 81.19 & Tie to & U1335B-9H-2, 24 & 71.54 & 81.19 \\
\hline U1335B-9H-6, 112 & 78.42 & 88.08 & Tie to & U1335A-9H-2, 109 & 77.99 & 88.08 \\
\hline U1335A-9H-5, 64 & 82.04 & 92.13 & Tie to & U1335B-10H-1, 93 & 80.23 & 92.13 \\
\hline U1335B-10H-5, 15 & 85.45 & 97.35 & Tie to & U1335A-10H-1, 140 & 86.30 & 97.35 \\
\hline U1335A-10H-7, 25 & 94.15 & 105.20 & Tie to & U1335B-11H-3, 29 & 92.09 & 105.20 \\
\hline U1335B-11H-6, 72 & 97.02 & 110.13 & Tie to & U1335A-11H-2, 137 & 97.27 & 110.13 \\
\hline U1335A-11H-5, 92 & 101.32 & 114.18 & Tie to & U1335B-12H-1, 138 & 99.68 & 114.18 \\
\hline U1335B-12H-6, 28 & 106.08 & 120.58 & Tie to & U1335A-12H-2, 109 & 106.49 & 120.58 \\
\hline U1335A-12H-5, 68 & 110.58 & 124.67 & Tie to & U1335B-13H-1, 148 & 109.28 & 124.67 \\
\hline U1335B-13H-6, 85 & 116.15 & 131.55 & Tie to & U1335A-13H-4, 41 & 118.31 & 131.55 \\
\hline U1335A-13H-6, 27 & 121.17 & 134.41 & Tie to & U1335B-14H-1, 38 & 117.68 & 134.41 \\
\hline U1335B-14H-5, 24 & 123.54 & 140.28 & Tie to & U1335A-14H-2, 59 & 124.99 & 140.28 \\
\hline U1335A-14H-5, 95 & 129.85 & 145.15 & Tie to & U1335B-15H-1, 99 & 127.79 & 145.15 \\
\hline U1335B-15H-5, 94 & 133.74 & 151.10 & Tie to & U1335A-15H-2, 85 & 134.75 & 151.10 \\
\hline U1335A-15H-6, 145 & 140.85 & 157.20 & Tie to & U1335B-16H-2, 12 & 137.92 & 157.20 \\
\hline U1335B-16H-7, 56 & 145.86 & 165.14 & Append to & U1335B-17H-1, 63 & 146.43 & 165.70 \\
\hline U1335B-17H-6, 116 & 154.46 & 173.73 & Tie to & U1335A-17H-2, 84 & 153.74 & 173.73 \\
\hline U1335A-17H-5, 75 & 158.15 & 178.14 & Tie to & U1335B-18H-2, 104 & 157.84 & 178.14 \\
\hline U1335B-18H-5, 112 & 162.42 & 182.72 & Tie to & U1335A-18H-1, 135 & 162.25 & 182.72 \\
\hline U1335A-18H-5, 47 & 167.37 & 187.84 & Tie to & U1335B-19H-1, 72 & 165.52 & 187.84 \\
\hline U1335B-19H-6, 87 & 173.17 & 195.48 & Tie to & U1335A-19H-3, 77 & 174.17 & 195.48 \\
\hline U1335A-19H-6, 89 & 178.79 & 200.10 & Tie to & U1335B-20H-2, 27 & 176.07 & 200.10 \\
\hline U1335B-20H-5, 153 & 181.83 & 205.86 & Tie to & U1335A-20H-3, 23 & 183.13 & 205.86 \\
\hline U1335A-20H-6, 107 & 188.47 & 211.19 & Tie to & U1335B-21H-2, 84 & 186.14 & 211.19 \\
\hline U1335B-21H-6, 94 & 192.24 & 217.29 & Tie to & U1335A-21H-3, 77 & 193.17 & 217.29 \\
\hline U1335A-21H-5, 118 & 196.58 & 220.70 & Tie to & U1335B-22H-1, 143 & 194.73 & 220.70 \\
\hline U1335B-22H-6, 37 & 201.17 & 227.14 & Tie to & U1335A-22H-2, 76 & 201.16 & 227.14 \\
\hline U1335A-22H-6, 57 & 206.97 & 232.95 & Tie to & U1335B-23H-1, 123 & 204.03 & 232.95 \\
\hline U1335B-23H-5, 97 & 209.77 & 238.69 & Tie to & U1335A-23H-2, 38 & 210.28 & 238.69 \\
\hline U1335A-23H-5, 105 & 215.45 & 243.86 & Tie to & U1335B-24H-1, 47 & 212.77 & 243.86 \\
\hline U1335B-24H-6, 5 & 219.85 & 250.94 & Tie to & U1335A-24H-1, 140 & 219.30 & 250.94 \\
\hline U1335A-24H-6, 52 & 225.92 & 257.56 & Tie to & U1335B-25H-3, 22 & 225.02 & 257.56 \\
\hline U1335B-25H-5, 96 & 228.76 & 261.30 & Tie to & U1335A-25H-1, 113 & 228.53 & 261.30 \\
\hline U1335A-25H-6, 16 & 235.06 & 267.84 & Tie to & U1335B-26H-2, 82 & 233.62 & 267.84 \\
\hline U1335B-26H-5, 37 & 237.67 & 271.89 & Tie to & U1335A-26H-1, 35 & 237.25 & 271.89 \\
\hline U1335A-26H-6, 30 & 244.70 & 279.34 & Tie to & U1335B-27H-2, 103 & 243.33 & 279.34 \\
\hline U1335B-27H-6, 141 & 249.71 & 285.72 & Tie to & U1335A-27H-2, 89 & 248.79 & 285.72 \\
\hline U1335A-27H-6, 13 & 254.03 & 290.96 & Tie to & U1335B-28H-3, 28 & 253.58 & 290.96 \\
\hline U1335B-28H-6, 18 & 257.98 & 295.36 & Tie to & U1335A-28H-2, 18 & 257.58 & 295.36 \\
\hline U1335A-28H-6, 11 & 263.51 & 301.29 & Tie to & U1335B-29H-2, 63 & 261.93 & 301.29 \\
\hline U1335B-29H-5, 107 & 266.87 & 306.23 & Tie to & U1335A-29H-1, 134 & 266.74 & 306.23 \\
\hline U1335A-29H-5, 120 & 272.60 & 312.09 & Tie to & U1335B-30H-1, 84 & 270.14 & 312.09 \\
\hline U1335B-30H-5, 116 & 276.46 & 318.41 & Tie to & U1335A-30H-2, 145 & 277.85 & 318.41 \\
\hline U1335A-30H-6, 122 & 283.62 & 324.18 & Tie to & U1335B-31H-2, 55 & 280.85 & 324.18 \\
\hline U1335B-31H-6, 78 & 287.08 & 330.41 & Tie to & U1335A-31H-3, 38 & 287.78 & 330.41 \\
\hline U1335A-31H-6, 21 & 292.11 & 334.74 & Tie to & U1335B-32H-1, 138 & 289.68 & 334.74 \\
\hline U1335B-32H-5, 147 & 295.77 & 340.83 & Tie to & U1335A-32H-2, 147 & 296.87 & 340.83 \\
\hline U1335A-32H-6, 106 & 302.46 & 346.42 & Tie to & U1335B-33H-2, 68 & 299.98 & 346.42 \\
\hline U1335B-33H-6, 81 & 306.11 & 352.55 & Tie to & U1335A-33H-3, 41 & 306.81 & 352.55 \\
\hline U1335A-33H-6, 44 & 311.34 & 357.08 & Tie to & U1335B-34H-2, 46 & 309.26 & 357.08 \\
\hline U1335B-34H-6, 75 & 315.55 & 363.37 & Tie to & U1335A-34H-3, 45 & 314.95 & 363.37 \\
\hline U1335A-34H-6, 61 & 319.61 & 368.03 & Tie to & U1335B-35H-1, 135 & 318.15 & 368.03 \\
\hline
\end{tabular}


Table T28 (continued).

\begin{tabular}{|c|c|c|c|c|c|c|}
\hline \multirow{2}{*}{$\begin{array}{l}\text { Hole, core, section, } \\
\text { interval }(\mathrm{cm})\end{array}$} & \multicolumn{2}{|c|}{ Depth (m) } & & \multirow{2}{*}{$\begin{array}{l}\text { Hole, core, section, } \\
\text { interval }(\mathrm{cm})\end{array}$} & \multicolumn{2}{|c|}{ Depth (m) } \\
\hline & CSF & CCSF-A & & & CSF & CCSF-A \\
\hline U1335B-35H-6, 39 & 324.69 & 374.57 & Tie to & U1335A-35H-1, 134 & 323.74 & 374.57 \\
\hline U1335A-35H-5, 89 & 329.29 & 380.12 & Tie to & U1335B-36H-2, 37 & 328.27 & 380.12 \\
\hline U1335B-36H-7, 14 & 335.54 & 387.39 & Tie to & U1335A-36H-3, 49 & 335.39 & 387.39 \\
\hline U1335A-36H-5, 45 & 338.35 & 390.35 & Tie to & U1335B-37H-1, 30 & 336.10 & 390.35 \\
\hline U1335B-37H-6, 40 & 343.70 & 397.95 & Append to & U1335B-38H-1, 8 & 343.88 & 398.12 \\
\hline U1335B-38H-6, 79 & 352.09 & 406.34 & Append to & U1335B-39H-1, 5 & 352.85 & 407.10 \\
\hline U1335B-39H-7, 41 & 362.21 & 416.46 & Append to & U1335B-40H-1, 8 & 362.38 & 416.62 \\
\hline U1335B-40H-6, 27 & 370.07 & 424.31 & Append to & U1335B-41H-1, 8 & 370.18 & 424.42 \\
\hline U1335B-41H-6, 36 & 377.96 & 432.21 & Append to & U1335B-42X-1, 23 & 378.43 & 432.67 \\
\hline U1335B-42X-6, 77 & 386.47 & 440.72 & Append to & U1335B-43X-1, 19 & 386.39 & 440.64 \\
\hline U1335B-43X-6, 90 & 394.60 & 448.85 & Append to & U1335B-44X-1, 19 & 395.99 & 450.24 \\
\hline U1335B-44X-6, 104 & 404.34 & 458.58 & Append to & U1335B-45X-1, 24 & 405.64 & 459.89 \\
\hline U1335B-45X-4, 147 & 411.37 & 465.62 & Append to & U1335B-46X-1, 9 & 415.09 & 469.34 \\
\hline
\end{tabular}


Table T29. Magnetostratigraphic and biostratigraphic datums, Site U1335. (See table note.) (Continued on next page.)

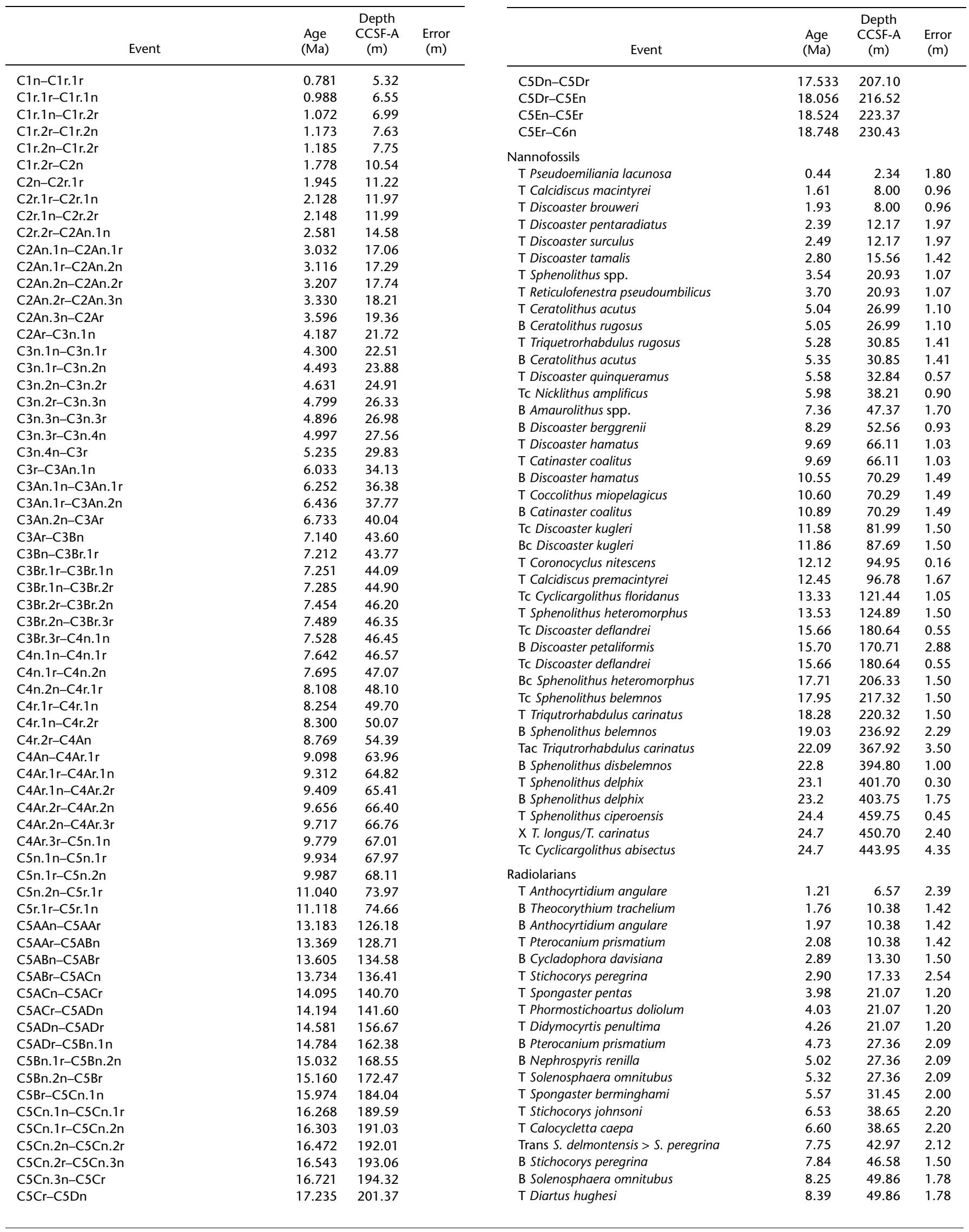


Table T29 (continued).

\begin{tabular}{|c|c|c|c|c|c|c|c|}
\hline Event & $\begin{array}{c}\text { Age } \\
(\mathrm{Ma})\end{array}$ & $\begin{array}{l}\text { Depth } \\
\text { CCSF-A } \\
\text { (m) }\end{array}$ & $\begin{array}{c}\text { Error } \\
(\mathrm{m})\end{array}$ & Event & $\begin{array}{l}\text { Age } \\
\text { (Ma) }\end{array}$ & $\begin{array}{l}\text { Depth } \\
\text { CCSF-A } \\
(\mathrm{m})\end{array}$ & $\begin{array}{c}\text { Error } \\
(\mathrm{m})\end{array}$ \\
\hline T Botryostrobus miralestensis & 8.59 & 56.95 & 1.50 & T Liriospyris longicornuta & 24.12 & 438.43 & 1.19 \\
\hline T Diartus petterssoni & 8.63 & 56.95 & 1.50 & T Lychnocanoma apodora & 24.50 & 441.68 & 2.07 \\
\hline Trans $D$. petterssoni $>D$. hughesi & 8.76 & 60.45 & 2.00 & B Lychnocanoma elongata & 25.05 & 447.52 & 0.77 \\
\hline B Spongaster berminghami & 8.76 & 64.23 & 1.78 & B Acrocubus octopylus & 25.09 & 447.52 & 0.77 \\
\hline T Stichocorys wolffii & 8.95 & 64.23 & 1.78 & B Calocycletta robusta & 25.27 & 464.46 & 1.50 \\
\hline B Diartus hughesi & 8.99 & 64.23 & 1.78 & B Liriospyris longicornuta & 25.29 & 464.46 & 1.50 \\
\hline T Cyrtocapsella japonica & 10.31 & 67.52 & 1.50 & B Lychnocanoma apodora & 25.55 & 464.46 & 1.50 \\
\hline T Carpocanopsis cristata & 10.88 & 71.18 & 2.16 & Foraminifers & & & \\
\hline T Cyrtocapsella cornuta & 11.86 & 93.08 & 2.04 & T Globigerinoides fistulosus & 1.77 & 11.13 & 1.32 \\
\hline B Diartus petterssoni & 12.11 & 100.01 & 1.50 & B Globorotalia (Truncorotalia) truncatulinoides & 1.92 & 7.90 & 1.20 \\
\hline B Cyrtocapsella japonica & 12.41 & 107.90 & 1.91 & T Globigerinoides extremus & 1.98 & 9.59 & 1.32 \\
\hline B Lithopera neotera & 12.95 & 107.90 & 1.91 & T Globorotalia pseudomiocenica & 2.30 & 9.59 & 1.32 \\
\hline T Stichocorys armata & 13.50 & 125.74 & 2.20 & T Globoturborotalita woodi & 2.30 & 13.95 & 1.50 \\
\hline T Acrocubus octopyle & 13.88 & 125.74 & 2.20 & T Globorotalia (Menardella) multicamerata & 2.98 & 23.09 & 1.50 \\
\hline T Calocycletta costata & 14.23 & 134.42 & 2.22 & T Dentoglobigerina altispira & 3.47 & 43.54 & 5.68 \\
\hline T Dorcadospyris dentata & 14.67 & 163.32 & 0.59 & T Sphaeroidinellopsis seminulina & 3.59 & 16.48 & 1.50 \\
\hline Trans $D$. dentata $>D$. alata & 14.78 & 170.89 & 3.05 & B Globorotalia (Menardella) exilis & 4.45 & 17.65 & 2.21 \\
\hline T Liriospyris stauropora & 14.83 & 163.32 & 0.59 & B Sphaeroidinella dehiscens s.I. & 5.54 & 23.01 & 2.43 \\
\hline B Liriospyris parkerae & 15.03 & 174.92 & 0.97 & B Globorotalia tumida & 5.57 & 31.36 & 1.89 \\
\hline B Dorcadospyris alata & 15.08 & 174.92 & 0.97 & B Globorotalia (Hirsutella) margaritae & 6.08 & 43.92 & 0.95 \\
\hline T Carpocanopsis cingulata & 15.13 & 186.39 & 0.54 & B Globorotalia plesiotumida & 8.58 & 58.93 & 2.67 \\
\hline T Lychnocanoma elongata & 15.15 & 186.39 & 0.54 & T Globorotalia (Menardella) praemenardii & 10.09 & 74.08 & 4.55 \\
\hline B Lithopera renzae & 16.77 & 192.23 & 2.03 & T Paragloborotalia mayeri & 10.46 & 73.36 & 0.69 \\
\hline B Calocycletta costata & 17.49 & 199.50 & 2.23 & B Globoturborotalita decoraperta & 11.49 & 80.37 & 0.71 \\
\hline B Dorcadospyris dentata & 17.72 & 210.39 & 2.22 & B Globoturborotalita nepenthes & 11.63 & 86.66 & 0.71 \\
\hline B Liriospyris stauropora & 17.72 & 213.59 & 0.99 & T Globorotalia (Fohsella) fohsi s.I. & 11.79 & 86.64 & 1.50 \\
\hline B Stichocorys wolffii & 18.57 & 241.84 & 0.54 & B Globorotalia (Fohsella) fohsi robusta & 13.13 & 118.54 & 0.81 \\
\hline B Dorcadospyris forcipata & 18.61 & 261.11 & 1.62 & B Globorotalia (Fohsella) fohsi s.I. & 13.41 & 120.96 & 4.03 \\
\hline T Dorcadospyris simplex s.s. & 18.69 & 261.11 & 1.62 & T Globorotalia praescitula & 13.73 & 127.37 & 4.79 \\
\hline T Dorcadospyris praeforcipata & 19.77 & 283.64 & 2.21 & B Globorotalia (Fohsella) "praefohsi" & 13.77 & 128.69 & 2.03 \\
\hline B Dorcadospyris simplex s.s. & 20.34 & 301.49 & 2.26 & T Globorotalia (Fohsella) peripheroronda & 13.80 & 131.17 & 2.56 \\
\hline B Stichocorys delmontensis & 20.68 & 303.20 & 2.26 & T Clavatorella bermudezi & 13.82 & 131.33 & 0.20 \\
\hline T Lophocyrtis pegetrum & 20.89 & 323.93 & 1.41 & B Globorotalia (Fohsella) peripheroacuta & 14.24 & 141.58 & 1.50 \\
\hline T Theocyrtis annosa & 21.38 & 332.06 & 0.53 & B Clavatorella bermudezi & 14.89 & 141.58 & 1.50 \\
\hline B Calocycletta virginis & 21.39 & 332.06 & 0.53 & B Globorotalia (Menardella) archeomenardii & 16.26 & 179.52 & 2.65 \\
\hline T Eucyrtidium mitodes & 21.95 & 356.97 & 2.27 & B. Praeorbulilna sicana & 16.97 & 191.20 & 1.28 \\
\hline B Calocycletta serrata & 22.04 & 363.90 & 0.52 & T Catapsydrax dissimilis & 17.54 & 213.94 & 4.54 \\
\hline B Cyrtocapsella cornuta & 22.26 & 394.88 & 1.07 & T Globoquadrina binaiensis & 19.09 & 207.07 & 4.78 \\
\hline B Cyrtocapsella tetrapera & 22.35 & 394.88 & 1.07 & T Paragloborotalia kugleri & 21.12 & 308.74 & 2.59 \\
\hline T Artophormis gracilis & 22.62 & 408.12 & 0.53 & T Paragloborotalia pseudokugleri & 21.31 & 308.74 & 2.59 \\
\hline B Eucyrtidium diaphanes & 22.95 & 419.28 & 2.09 & B Globoquadrina dehiscens & 22.44 & 361.54 & 1.94 \\
\hline T Dorcadospyris cyclacantha & 22.98 & 408.12 & 0.53 & B Paragloborotalia kugleri & 23.0 & 401.67 & 1.38 \\
\hline B Dorcadospyris cyclacantha & 23.29 & 419.28 & 2.09 & B Paragloborotalia pseudokugleri & 25.2 & 445.01 & 4.12 \\
\hline
\end{tabular}

Note: $\mathrm{T}=$ top, $\mathrm{B}=$ bottom, $\mathrm{Tc}=$ Top common occurrence, $\mathrm{BC}=$ Bottom common occurrence, Tac $=$ top acme, $\mathrm{X}=$ abundance crossover, Trans $=$ transition. 
Table T30. Results from APCT-3 temperature profiles, Hole U1335B. (See table notes.)

\begin{tabular}{lccccc}
\hline & \multicolumn{2}{c}{ Temperature $\left({ }^{\circ} \mathrm{C}\right)$} & & & \\
\cline { 2 - 3 } Core & $\begin{array}{c}\text { Average } \\
\text { at } \\
\text { mudline }\end{array}$ & $\begin{array}{c}\text { Minimum } \\
\text { above } \\
\text { mudline }\end{array}$ & $\begin{array}{c}\text { Depth } \\
\text { DSF } \\
(\mathrm{m})\end{array}$ & $\begin{array}{c}\text { In situ } \\
\text { temperature } \\
\left({ }^{\circ} \mathrm{C}\right)\end{array}$ & $\begin{array}{c}\text { Thermal } \\
\text { resistance } \\
\left(\mathrm{m}^{2} \mathrm{~K} / \mathrm{m}\right)\end{array}$ \\
\hline $320-\mathrm{U} 1335 \mathrm{~B}-$ & & & & & \\
$3 \mathrm{H}$ & 1.498 & 1.474 & 22.3 & 1.64 & 24.9 \\
$5 \mathrm{H}$ & 1.500 & 1.468 & 41.3 & 1.83 & 47.3 \\
7H & 1.511 & 1.465 & 60.3 & 2.00 & 67.8 \\
$9 \mathrm{H}$ & 1.493 & 1.463 & 79.3 & 2.00 & 87.1 \\
$11 \mathrm{H}$ & 1.510 & 1.473 & 98.3 & 2.22 & 104.4 \\
Average: & 1.502 & 1.469 & & & \\
\hline
\end{tabular}

Notes: In situ temperatures were determined using the TP-Fit software by Martin Heesemann. Thermal resistance was calculated from thermal conductivity data (see "Physical properties") corrected for in situ conditions (see "Downhole measurements" in the "Methods" chapter). 